ANA PAULA PARRA LEITE

\title{
EQUILÍBRIO CONTRATUAL
}

Tese de Doutorado

Professor Orientador: Doutor Claudio Luiz Bueno de Godoy

FACULDADE DE DIREITO DO LARGO DO SÃO FRANCISCO

UNIVERSIDADE DE SÃO PAULO

SÃO PAULO

2013 


\section{EQUILÍBRIO CONTRATUAL}

Tese apresentada à Banca Examinadora da Faculdade de Direito da Universidade de São Paulo, como exigência parcial para a obtenção do título de Doutora em Direito Civil, sob a orientação do Prof. Dr. Claudio Luiz Bueno de Godoy. 
ANA PAULA PARRA LEITE

\section{EQUILÍBRIO CONTRATUAL}

Tese de Doutorado em Direito Civil

BANCA EXAMINADORA

Orientador: Professor Doutor Claudio Luiz Bueno de Godoy

São Paulo,

FACULDADE DE DIREITO DO LARGO DO SÃO FRANCISCO

UNIVERSIDADE DE SÃO PAULO

SÃO PAULO

2013 


\section{AGRADECIMENTOS}

Ao meu orientador Dr. Claudio Luiz Bueno de Godoy, pela paciência e disponibilidade.

Ao Dr. Renan Lotufo e Dr. Nestor Duarte. Aquele por despertar o gosto pelo Direito Civil e este pela confiança depositada em uma desconhecida.

Aos meus pais, Honório (in memoriam) e Marilene por sempre focarem na educação das filhas.

Ao meu amado marido Fábio pelo apoio irrestrito e por cuidar das minhas filhas durante minhas viagens.

Às minhas filhas Maria Eduarda, Maria Antônia e Mariana (in memoriam), simplesmente, por ter recebido a benção divina de ser mãe de vocês. 


\section{RESUMO}

O presente trabalho tem por objetivo o estudo do equilíbrio contratual, especificamente em matéria de alteração de circunstâncias negociais tanto nas relações paritárias quanto nas relações consumeristas. Pretende-se analisar as influências recíprocas entre o Código Civil e o Código de Defesa do Consumidor, sob a ótica da teoria do "diálogo das fontes" de Erik Jayme. Para tanto, fez-se uma análise dos princípios contratuais vigentes, da cláusula rebus sic stantibus na história e em diversos países, e também das várias teorias que pretenderam solucionar os problemas decorrentes de desequilíbrio superveniente, tais como as teorias da pressuposição, da vontade marginal, da base negocial objetiva, entre outras. Abordou-se, ainda, os requisitos exigidos para a invocação da alteração das circunstâncias no Direito Civil e no Código de Defesa do Consumidor e como estes dois sistemas interagem entre si.

Palavras-chave: contratos - equilíbrio - revisão - diálogo das fontes 


\begin{abstract}
The present work aims to study the contractual balance, specifically in terms of contractual change of circumstances not only in parity relations, but also in consumers' relations. It was intended to analyze the mutual influences between the Civil Code and the Consumers Defense Code under the light of the theory of the "dialogue of sources" by Erik Jayme. Therefore, an analysis of the current contractual principles was made, as well as an analysis of the clause rebus sic stantibus along history and in different countries and also of the various theories that sought to solve the problems due to supervening unbalance, such as theories of presupposition, the marginal willingness, the negotial objective base, among others. It was also addressed, the requirements for the invocation of changed circumstances in Civil Law and in the Consumers Defense Code and how these two systems interact with each other.
\end{abstract}

Key words: contracts - balance - review - dialogue of sources. 


\section{SUMÁRIO}

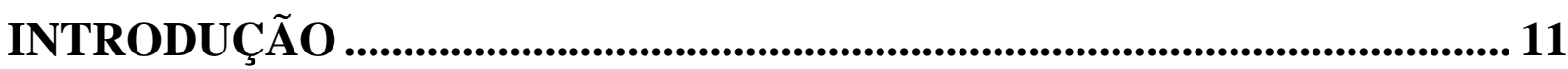

CAPÍTULO I - O CÓDIGO CIVIL E O DIREITO CONTRATUAL............. 13 CAPÍTULO II - OS PRINCÍPIOS INFORMADORES DOS CONTRATOS.. 18

2.1 GENERALIDADES.................................................................................................. 18

2.2 PRINCÍPIO DA AUTONOMIA DA VONTADE .............................................. 18

2.3 PRINCÍPIO DA OBRIGATORIEDADE ........................................................... 20

2.4 PRINCÍPIO DA RELATIVIDADE DOS CONTRATOS................................. 21

2.5 PRINCÍPIO DA BOA-FÉ ............................................................................. 22

2.5.1 As funções do Princípio da Boa-Fé................................................................. 26

2.6 PRINCÍPIO DA FUNÇÃO SOCIAL DO CONTRATO................................... 32

2.7 PRINCÍPIO DO EQUILÍBRIO CONTRATUAL................................................35

CAPÍTULO III - A CLÁUSULA REBUS SIC STANTIBUS ............................... 38

3.1 CLÁUSULA REBUS SIC STANTIBUS - HISTÓRICO ..................................... 38

3.1.1 Na Antiguidade ....................................................................................................... 38

3.1.2 Na Idade Média .................................................................................................... 42

3.1.3 Na Idade Moderna............................................................................................. 44

3.2 A CLÁUSULA REBUS SIC STANTIBUS NO BRASIL .....................................58

CAPÍTULO IV - TEORIAS RELATIVAS À ALTERAÇÃO DAS CIRCUNSTÂNCIAS

4.1 TEORIA DA PRESSUPOSIÇÃO DE WINDSCHEID......................................63

4.2 TEORIA DA VONTADE MARGINAL DE GIUSEPPE OSTI ...................... 67

4.3 TEORIA DA VONTADE EFICAZ DE ERICH KAUFMANN ....................... 68

4.4 TEORIA DA RESERVA VIRTUAL DE PAUL KRÜCKMANN .................. 69

4.5 TEORIA DA BASE SUBJETIVA DO NEGÓCIO JURÍDICO DE PAUL

OERTMANN …………......................................................................................... 70

4.6 TEORIA DA BASE OBJETIVA DO NEGÓCIO JURÍDICO DE KARL LARENZ ......................................................................................................... 73

4.7 TEORIA DO DEVER DE ESFORÇO DE HARTMANN ................................. 74 
4.8 A CLÁUSULA REBUS SIC STANTIBUS COM FUNDAMENTO NA

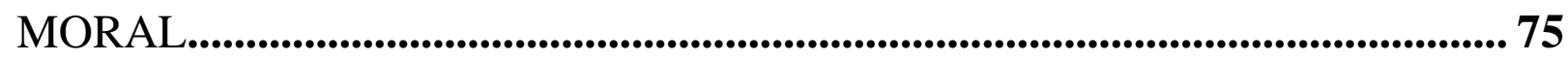

4.9 A CLÁUSULA REBUS SIC STANTIBUS COM FUNDAMENTO NA BOAFÉ .76

\section{CAPÍTULO V - A ALTERAÇÃO DAS CIRCUNSTÂNCIAS NO CÓDIGO} CIVIL BRASILEIRO .78

5.1 REQUISITOS POSITIVOS 80

5.1.1 Contratos de execução continuada, sucessiva ou diferida ................................ 80

5.1.2 Excessiva onerosidade na prestação para uma das partes................................. 85

5.1.3 Acontecimentos extraordinários e imprevisíveis .................................................90 90

5.1.4 Extrema vantagem para a outra parte..................................................................... 94

5.2 REQUISITOS NEGATIVOS..............................................................96

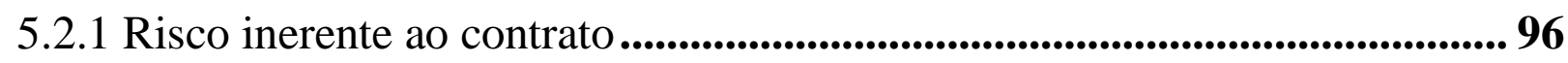

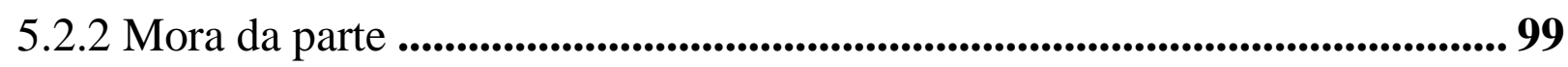

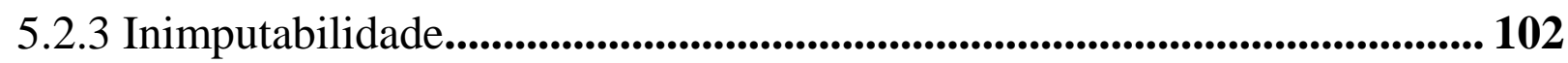

5.3 APLICAÇÃO AOS CONTRATOS ALEATÓRIOS......................................104

5.4 A REVISÃO E A APLICAÇÃO DO ARTIGO 479 DO CÓDIGO CIVIL. 107

5.5 APLICAÇÃO DO ARTIGO 480 DO CÓDIGO CIVIL..................................114

5.6 A APLICAÇÃO DO ARTIGO 317 DO CÓDIGO CIVIL.............................117

5.7 A DEMANDA REVISIONISTA..........................................................119

5.8 A VALIDADE DE CLÁUSULA QUE IMPEÇA A REVISÃO/RESOLUÇÃO ALTERAÇÃO DAS CIRCUNSTÂNCIAS E DA CLÁUSULA DE RENEGOCIAÇÃO. 124

CAPÍTULO VI - O EQUILÍBRIO CONTRATUAL NO CÓDIGO DE DEFESA DO CONSUMIDOR E O CONFRONTO COM O CÓDIGO CIVIL

6.1 GENERALIDADES SOBRE O DIREITO DO CONSUMIDOR 132

6.2 O EQUILÍBRIO CONTRATUAL NO CÓDIGO DE DEFESA DO CONSUMIDOR 136

6.3 O DIÁLOGO ENTRE CÓDIGO CIVIL E CÓDIGO DE DEFESA DO CONSUMIDOR EM RELAÇÃO À ALTERAÇÃO DAS CIRCUNSTÂNCIAS. 
6.3.1 Aspectos gerais

6.3.2 Inexigência de imprevisibilidade e extraordinariedade do evento superveniente.

6.3.3 Possibilidade de revisão do contrato de consumo ex officio......................... 146

6.3.4 Excessiva onerosidade para uma das partes................................................... 147

6.3.5 Do estado moroso do consumidor e inimputabilidade................................... 150

6.3.6 Opção entre revisão e resolução............................................................................. 153

6.3.7 Contratos de consumo passíveis de revisão/resolução................................. 154

6.3.8 Desnecessidade de extrema vantagem para a outra parte para a revisão do

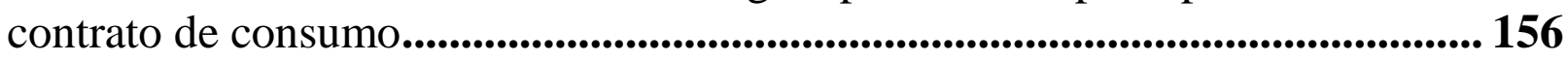

6.3.9 Legitimidade ativa para a demanda revisionista/resolutória........................ 155

6.3.9 A questão da possibilidade de inserção de cláusula impeditiva de revisão contratual por alteração das circunstâncias e cláusula de renegociação ............... 157

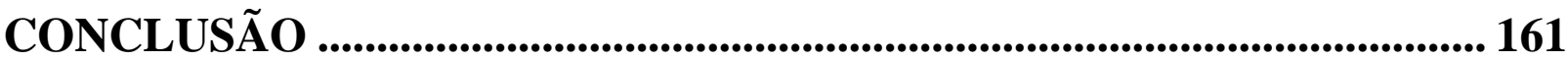

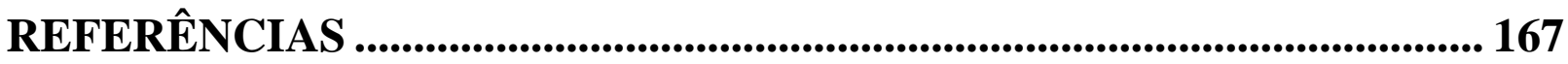




\section{INTRODUÇÃO}

A problemática do equilíbrio contratual há muitos anos ocupa estudiosos do Direito, ora dando-se prevalência à força obrigatória do contrato, ora à necessidade de manutenção de uma justiça contratual.

O Código Civil de 1916, seguindo o modelo proposto pelo Código Napoleônico, era impregnado de uma ideologia liberal, na qual o Estado não intervinha nas relações particulares. Desta forma, os negócios jurídicos firmados sob a sua égide eram fortemente influenciados pelo dogma da vontade, concebendo-se os contratos como se fizessem "lei entre as partes", o que impedia a sua revisão na hipótese de desequilíbrio nas prestações.

As duas grandes guerras mundiais trouxeram a necessidade de maior proteção à dignidade da pessoa humana, a busca pela ética e pelo solidarismo. Com isso, o Estado, paulatinamente, passou a intervir nas relações privadas em busca da igualdade e da solidariedade; o social passou a prevalecer sobre o individual.

Neste contexto solidarista, entrou em vigor a Constituição Federal de 1988, atribuindo à dignidade da pessoa humana o qualitativo de fundamento da República Federativa do Brasil (artigo $1^{\circ}$, inciso III). Ao mesmo tempo, a República passou a ter como objetivos a construção de uma sociedade livre, justa e solidária, a erradicação da pobreza e a marginalização e a redução das desigualdades sociais e regionais (artigo $3^{\circ}$, incisos I e III).

Com esta nova ordem jurídica, os contratos sofreram modificações, mitigando-se o dogma da vontade, passando a primar pela socialidade, pelo equilíbrio e pela solidariedade. Os contratos, nestes termos, não podem mais ser instrumento para relações espoliativas, de forma que seus princípios informadores sofreram alterações.

No presente estudo, pretende-se analisar a temática do equilíbrio contratual, mormente no âmbito das relações paritárias, confrontando-as com a relação consumerista, apontando semelhanças e diferenças entre as duas.

Para tanto, o trabalho está estruturado em seis capítulos.

No primeiro capítulo, intitulado "O Código Civil e o Direito Contratual”, analisa-se o Direito Contratual no Código Civil de 2002.

No segundo capítulo, intitulado "Os princípios informadores dos contratos", são abordados os princípios da autonomia da vontade, da obrigatoriedade, da relatividade, da boafé objetiva (e suas funções), da função social do contrato e equilíbrio contratual, fazendo-se uma comparação com os princípios contratuais na sua abordagem clássica vigente, sob a 
égide do Código Civil de 1916.

O terceiro capítulo aborda a chamada cláusula rebus sic stantibus através dos tempos, seus momentos de apogeu e de declínio, sua aplicação no Brasil e em outros países, tais como Itália, Alemanha, Portugal e Argentina.

No capítulo quarto, são analisadas as teorias que buscam explicar a chamada alteração das circunstâncias, tais como a teoria da pressuposição de Windscheid, teoria da vontade marginal de Osti, teoria da base negocial subjetiva e objetiva de Oertmann e Larenz, respectivamente, entre outras.

O quinto capítulo tem por objeto o estudo da onerosidade excessiva no Código Civil de 2002, mormente através da análise dos artigos 478 a 480. Para tanto, são analisados os requisitos positivos para a sua configuração, bem como os chamados requisitos negativos, diante dos quais se verifica a inaplicabilidade do instituto da onerosidade excessiva.

Entretanto, conforme se observará, nem sempre a solução buscando atingir o equilíbrio contratual diante da alteração das circunstâncias e da onerosidade excessiva será fácil e cristalina; por isso mesmo, inúmeras críticas são tecidas pela doutrina à solução legislativa adotada. Assim, alguns aspectos controvertidos da matéria serão abordados, tais como a possibilidade de revisão por onerosidade excessiva de contrato aleatório; interpretação do disposto no artigo 480; conceito de previsibilidade; necessidade de extraordinariedade do evento superveniente para a possibilidade de revisão; a demanda proposta pelo prejudicado; os limites da decisão judicial a ser proferida, entre outros.

No capítulo sexto, pretende-se fazer uma análise do equilíbrio contratual na relação consumerista, onde serão apontadas as semelhanças e diferenças com a relação civil. Considerando-se que o Direito do Consumidor é um direito recente, pois data da década de 60, indaga-se a possibilidade de aplicação dos preceitos do Direito Civil relativos ao equilíbrio contratual à relação consumerista, abordando-se temas como a necessidade de imprevisibilidade e extraordinariedade do evento superveniente, mora do consumidor, legitimidade para propositura da ação revisionista, quais contratos de consumo são passíveis de revisão por onerosidade excessiva, a necessidade ou não de extrema vantagem para o consumidor, entre outros. Pretende-se, portanto, utilizar a teoria do "diálogo das fontes" de Erik Jayme para verificar a possibilidade de aplicação dos preceitos do Direito Civil ao Direito do Consumidor e vice-versa.

Finalizando, foram elaboradas as considerações finais, à guisa de conclusão. 


\section{CAPÍTULO I}

\section{O CÓDIGO CIVIL E O DIREITO CONTRATUAL}

O Código Civil de 1916 foi elaborado na esteira do pensamento da grande codificação que foi o Código Civil francês, conhecido como o Código Napoleônico e que entrou em vigor em 1804. Com o Código Napoleônico, o que se pretendia era assegurar, por meio de um texto escrito, todos os direitos pelos quais os franceses tanto lutaram por ocasião da Revolução Francesa, mormente a liberdade e a igualdade.

No momento da entrada em vigor do Código Civil francês, assim como no momento da entrada em vigor do nosso Código Civil de 1916, imperava um Estado liberal, nãointervencionista, que implicava a liberdade de contratar e uma igualdade entre as partes, mas uma igualdade formal. Imperava, é bem verdade, um individualismo exacerbado, não havendo preocupação com a justiça, ou seja, "se afinal o contrato guardava ou não uma distribuição equitativa de ônus e riscos". ${ }^{1}$

Nas palavras de Teresa Negreiros, a vontade passa a ser o cerne do contrato e o liberalismo econômico inspira-se na valorização da vontade individual como elemento de garantia do equilíbrio econômico e da prosperidade. ${ }^{2}$

Neste diapasão, Friedrich Carl Von Savigny elaborou a chamada "teoria da vontade", segundo a qual a vontade seria elemento essencial do negócio, constituindo a "declaração" um simples meio de exteriorização da vontade negocial. ${ }^{3}$

Havia uma crença de que o contrato traria em si uma natural equidade e proporcionaria a harmonia social e econômica se fosse assegurada a liberdade contratual. ${ }^{4}$ Por sua vez, a liberdade contratual tinha como fonte a liberdade individual quase que absoluta, em um tempo marcado pelo

[...] forte individualismo, em que se concedia a tutela jurídica para que o indivíduo, isoladamente, pudesse desenvolver com plena liberdade sua atividade econômica. Os limites à autonomia da vontade haviam de ser aqueles estritamente necessários a manter a convivência social. ${ }^{\mathbf{5}}$

Nesse contexto, forte na concepção individualista, em que as partes poderiam

\footnotetext{
${ }^{1}$ SAMPAIO. Laerte Marrone de Castro. A boa-fé objetiva na relação contratual. Barueri: Manole, 2004. p. 14

${ }^{2}$ NEGREIROS, Teresa. Teoria do contrato: novos paradigmas. Rio de Janeiro: Renovar, 2002. p. 26-27.

${ }^{3}$ MIRANDA, Custódio da Piedade Ubaldino. Teoria geral do negócio jurídico. São Paulo: Atlas, 2009. p. 23.

${ }^{4}$ SAMPAIO, Laerte Marrone de Castro. Op. cit., p. 11.

${ }^{5}$ Ibid., p. 10.
} 
determinar os efeitos que desejassem através de seus negócios jurídicos, o Código Civil francês proclamava, no seu artigo 1.134, ser o contrato lei entre as partes.

O Código Civil de 1916 surgiu com o mesmo ideal de outras grandes codificações, como a já referida codificação francesa e a alemã (que é do ano de 1900). Com o passar do tempo, observou-se que esse modelo não intervencionista, com a liberdade irrestrita de contratar, acabava por acarretar o extremo oposto: a ausência de liberdade. Isso porque, por não serem as pessoas iguais - quer econômica, social ou culturalmente -, acabava-se por aumentar ainda mais as desigualdades e, consequentemente, acarretar a prevalência do mais forte sobre o mais fraco, de forma a tolher a liberdade deste.

Objetivando mitigar essas diferenças, e com a modificação da concepção do Estado, que de Liberal passou a ser Social, verificou-se uma cada vez maior intervenção do Estado na esfera privada, como tentativa de resgate da liberdade e da igualdade (desta vez, uma igualdade material). Segundo Luiz Edson Fachin, a intervenção do Estado nas relações jurídicas privadas foi relevante e a liberdade contratual passou a ser vista de forma mitigada. ${ }^{6}$

$\mathrm{Na}$ verdade, a liberdade sem freios

[...] estava esmagando outros valores humanos tão fundamentais como ela própria. O protesto do Padre Lacordeire ressoava nas consciências: 'Entre le fort et le faible c'est la liberté qui opprime et la loi qui affranchit'. Entre o forte e o fraco, é a liberdade que oprime, e a lei que liberta!". 7

Em decorrência da necessidade de valorização da pessoa, inúmeros direitos que eram representativos do grande ramo do direito privado, tais como a família, a propriedade e o contrato, passaram a receber maior proteção constitucional, surgindo, então, o Direito Civil Constitucional, que acabou por gerar questionamentos sob o argumento de que não seria possível um Direito Civil inconstitucional. Mas, na verdade, não é isto que se pretende com a denominação Direito Civil Constitucional.

O fenômeno, que revela a chamada publicização do direito privado, implica um cânone interpretativo e diretivo das relações negociais e "consiste em um discurso de defesa dos princípios constitucionais e, especificamente, da sua direta e imediata aplicação a todas as relações jurídicas - aí incluídas as relações tipicamente de natureza civil, travadas entre os particulares."

\footnotetext{
${ }^{6}$ FACHIN, Luiz Edson. Repensando fundamentos de direito civil brasileiro contemporâneo. São Paulo: Renovar, 1998. p. 199-200.

${ }^{7}$ SAMPAIO, Laerte Marrone de Castro. A boa-fé objetiva na relação contratual. Barueri: Manole, 2004. p. 19.

${ }^{8}$ NEGREIROS, Teresa. Teoria do contrato: novos paradigmas. Rio de Janeiro: Renovar, 2002. p. 67.
} 
Isto porque a análise dos negócios jurídicos deve ser feita, sempre, à luz dos ditames previstos pela Constituição Federal, que, entre tantos artigos, prevê a dignidade da pessoa humana como fundamento da República Federativa do Brasil (artigo $1^{\circ}$, inciso III), e que tem como objetivo a construção de uma sociedade livre justa e solidária (artigo $3^{\circ}$, inciso I).

No inciso IV do artigo $1^{\circ}$, o legislador constituinte afirmou ainda serem fundamentos da República Federativa do Brasil "os valores sociais do trabalho e da livre iniciativa”, sendo que no artigo $3^{\circ}$, inciso III, foi inserido como seu objetivo fundamental "erradicar a pobreza e a marginalização e reduzir as desigualdades sociais e regionais".

Assim, de acordo com Alexandre Malfatti:

O direito constitucional passa a ter papel relevante sobre todo o ordenamento jurídico e vai além de simples organização da forma estatal e de modelo de governo. $\mathrm{O}$ direito constitucional começa a exercer a função essencial no contato com os outros ramos do direito, inclusive sobre o direito privado.

Seguindo os parâmetros ditados pela Constituição Federal, inúmeros dispositivos legais entraram em vigor com o objetivo de se atingir um equilíbrio nas relações contratuais, limitando a livre determinação do conteúdo dos negócios jurídicos, como forma de se resgatar a dignidade, a igualdade e a liberdade. Exemplo disto é o Código de Defesa do Consumidor, que inseriu inúmeras limitações à liberdade contratual, a fim de possibilitar ao consumidor uma maior proteção, visto que é evidente sua inferioridade diante da outra parte contratante. No mesmo sentido, foi elaborada lei de repressão à concorrência desleal, com o propósito de evitar o abuso do poder econômico.

O Código Civil de 1916 mostrou-se desatualizado diante da realidade social do pósguerra, da concentração de capital, da modificação no sistema de produção e distribuição e da massificação das relações, tornando-se imperiosa a elaboração de um novo codex, orientado pelo primado constitucional de proteção de dignidade da pessoa humana e de solidariedade.

Em 1972, fruto do trabalho de uma comissão composta por José Carlos Moreira Alves, Agostinho de Arruda Alvim, Sylvio Marcondes, Ebert Vianna Chamoun, Clóvis do Couto e Silva e Torquato Castro, encarregados, respectivamente, da Parte Geral, Direito das Obrigações, Atividade Negocial, Direito das Coisas, Direito de Família e Direito das Sucessões, cujas atribuições foram supervisionadas por Miguel Reale, surgiu o Anteprojeto que deu origem ao Projeto de Lei n. 634, de 1975, depois n. 634-B. Após inúmeras emendas,

\footnotetext{
${ }^{9}$ MALFATTI, Alexandre. Liberdade contratual. In: LOTUFO, Renan (Coord.). Cadernos de autonomia privada. Curitiba: Juruá, 2001. p. 24.
} 
o atual Código Civil brasileiro foi promulgado em 10 de janeiro de 2002, pela Lei n. 10.406, com prazo de vacatio legis de um ano, entrando em vigor no dia 11 de janeiro de 2003.

O Código Civil de 2002, atento para a necessidade de modificações no direito privado impostas pela Constituição Federal, foi informado, como ensina Miguel Reale ${ }^{\mathbf{1 0}}$, por três princípios: socialidade, eticidade e operabilidade. Segundo este autor, o "sentido social" é uma das características mais marcantes do Código e "houve o triunfo da socialidade", fazendo prevalecer os valores coletivos sobre os individuais, sem perda, porém, do valor fundante da pessoa humana.

Assinale-se que o Código Civil, limitando a liberdade de contratar, previu em seu artigo 421 que "A liberdade de contratar será exercida em razão e nos limites da função social do contrato". Atendendo a este dispositivo, um contrato não pode ser iníquo, abusivo. De acordo com Álvaro Villaça Azevedo, "Pelos contratos, os homens devem compreender-se e respeitar-se, para que encontrem um meio de entendimento e de negociação sadia de seus interesses e não um meio de opressão". ${ }^{11}$ A eticidade, por seu turno, revela uma "função mais criadora por parte da Justiça em consonância com o princípio de eticidade, cujo fulcro fundamental é o valor da pessoa humana como fonte de todos os valores". ${ }^{\mathbf{2}}$

Por fim, o princípio da operabilidade, objetivando dar maior concretude às disposições normativas, materializou-se nas normas abertas, não cerradas, "para que a atividade social mesma, na sua evolução, venha a alterar-lhe o conteúdo através daquilo que Reale denominou "estrutura hermenêutica". ${ }^{13}$

Seguindo a ideologia contida na Constituição Federal, foram inseridos no texto do Código Civil alguns dispositivos destinados a mitigar o desequilíbrio nas relações contratuais, como ocorre, por exemplo, com a possibilidade de revisão de contratos em decorrência da superveniência de acontecimentos extraordinários e imprevisíveis, que tornem a sua execução excessivamente onerosa para uma das partes (resolução por onerosidade excessiva - artigo 478 do Código Civil), além dos institutos da lesão e do estado de perigo.

O Código visou dar concretude ao direito, e esta concretude, segundo Reale, implicaria na obrigação que o legislador tem de

[...] não legislar em abstrato, para um indivíduo perdido na estratosfera,

\footnotetext{
${ }^{10}$ REALE, Miguel. O projeto do novo Código Civil. São Paulo: Saraiva, 1999. p. 7-12.

${ }^{11}$ AZEVEDO, Álvaro Villaça. O novo Código Civil brasileiro: tramitação; função social do contrato; boa-fé objetiva; teoria da imprevisão e, em especial, onerosidade excessiva (Laesio enormis). In: TEPEDINO, Gustavo; FACHIN, Luiz Edson (Coord.). O Direito e o tempo: embates jurídicos e utopias contemporâneas. Rio de Janeiro: Renovar, 2008. p. 15-16.

${ }^{12}$ REALE, Miguel. Op. cit., p. 9.

${ }^{13}$ Ibid., p. 7-12.
} 
mas, quanto possível, legislar para o indivíduo situado: legislar para o homem enquanto marido; para a mulher enquanto esposa; para o filho enquanto um ser subordinado ao poder familiar. ${ }^{14}$

Com isto, Reale propunha um texto que atendesse às situações sociais, ou seja, a "vivência plena do Código, do direito subjetivo como uma situação individual; não um direito subjetivo abstrato, mas uma situação subjetiva concreta". 15

Outra inovação trazida pelo atual Código Civil está em subordinar a liberdade contratual aos limites da função social do contrato (artigo 421). Nas palavras de Luiz Edson Fachin, o contrato "deixa de ser um instrumento do egoísmo individual, atingindo o nível de serviço às necessidades humanas. Fala-se em contrato como instrumento da paz social e ao bem comum, conectando-se a uma certa justiça contratual". ${ }^{16}$

Por justiça contratual, forte no pensamento de Guido Alpa, Fachin afirma que os contratantes não devem agir injustamente na relação, sem necessariamente se aproximarem de um senso de justiça, "mas definitivamente evitar qualquer ato injusto grave". ${ }^{17}$

Modernamente, verifica-se que há uma grande objetivização do contrato e do direito dos contratos, conforme ensina Enzo Roppo, acarretando uma diminuição da importância do elemento subjetivo da vontade e na importância acrescida do elemento objetivo da declaração ${ }^{18}$, para se atender, ao máximo, à "estabilidade e a continuidade das relações contratuais, e, portanto, das relações económicas". 19 Tal objetivização está diretamente relacionada ao aspecto social imposto pelo Estado moderno, abandonando-se o individualismo até então prevalente.

Com esta nova ideologia solidarista solidificada pela Constituição Federal de 1988, os contratos receberam, portanto, novos contornos. Com isto, seus princípios informadores também sofreram modificações sobre as quais se passa a analisar no capítulo que segue.

\footnotetext{
${ }^{14}$ REALE, Miguel. O projeto do novo Código Civil. São Paulo: Saraiva, 1999. p. 12.

${ }^{15}$ Loc. cit.

${ }^{16}$ FACHIN, Luiz Edson. Repensando fundamentos de direito civil brasileiro contemporâneo. São Paulo: Renovar, 1998. p. 200.

${ }^{17}$ Loc. cit.

${ }^{18}$ ROPPO, Enzo. O contrato. Coimbra: Almedina, 1977. p. 301.

${ }^{19}$ Ibid., p. 309.
} 


\section{CAPÍTULO II}

\section{OS PRINCÍPIOS INFORMADORES DOS CONTRATOS}

\subsection{GENERALIDADES}

Os contratos são informados por alguns princípios. Entretanto, com as já relatadas modificações trazidas pela Constituição Federal de 1988, os princípios clássicos inerentes aos contratos (autonomia da vontade, consensualismo, obrigatoriedade e relatividade) sofreram alterações em seu conteúdo, acrescentando-se-lhes ao rol de princípios contratuais os princípios da boa-fé, do equilíbrio econômico ${ }^{20}$ e o da função social do contrato.

Sobre os princípios informadores dos contratos, passa-se a discorrer.

\subsection{PRINCÍPIO DA AUTONOMIA DA VONTADE}

De acordo com a teoria contratual clássica, a vontade, por ser a propulsora dos negócios jurídicos, acabava por receber extrema importância, chegando Savigny a afirmar que se o declarante incidisse em erro sobre o conteúdo da declaração ou quando houvesse uma divergência entre o que quer e o que afinal declara, "o negócio jurídico não poderá subsistir sem o seu suporte essencial - a vontade - pelo que será inválido". 21

O liberalismo que impregnou inúmeros países no século XVIII refletiu-se nos contratos. Nesta toada, objetivando assegurar o ideal burguês, na França, concebia-se o contrato como "lei entre as partes". Nesse sentido, o artigo $1.134^{22}$ do Código Napoleônico previa que "As convenções feitas nos contratos formam para as partes uma regra à qual deve se submeter como a própria lei”. ${ }^{23}$

A autonomia da vontade pode ser conceituada como o poder que as pessoas têm de "estipular livremente o acordo de vontades, disciplinando seus interesses", ou seja, equivale a um "poder de autorregulamentação dos interesses. É a liberdade de firmar obrigações". ${ }^{24}$

De acordo com a teoria contratual clássica, típica do liberalismo, o princípio da

\footnotetext{
${ }^{20}$ Há autores, entretanto, que entendem que o princípio do equilíbrio econômico está associado à boa-fé. Assim, por exemplo, Judith Martins-Costa. A boa-fé no direito privado. São Paulo: Revista dos Tribunais, 1999.

${ }^{21}$ MIRANDA, Custódio da Piedade Ubaldino. Teoria geral do negócio jurídico. São Paulo: Atlas, 2009. p. 24.

${ }^{22}$ No original: "Les conventions légalement formées tiennent lieu de loi à ceux qui les ont faites".

${ }^{23}$ Tradução livre da autora.

24 NANNI, Giovanni Ettore. A evolução do Direito Civil obrigacional: a concepção do Direito Civil constitucional e a transição da autonomia da vontade para a autonomia privada. In: LOTUFO, Renan (Coord.). Cadernos de autonomia privada. Curitiba: Juruá, 2011. p. 168.
} 
autonomia da vontade refletia a liberdade de contratar, liberdade de escolher com quem contratar e também a liberdade de escolha do conteúdo e forma contratual. Este modelo contratual, individualista, marcou a vigência do Código Civil de 1916.

Entretanto, em razão de inúmeras modificações sociais, mormente em razão das duas grandes guerras mundiais, das inovações tecnológicas, da massificação das relações negociais, os "princípios até então aplicáveis aos contratos" mostraram-se insuficientes. ${ }^{25}$ Para reparar tal insuficiência, deparamo-nos com uma crescente intervenção do Estado nas relações privadas de forma a dirigir os contratos para resgatar um efetivo equilíbrio entre as partes. Isso se refletiu inicialmente, a título de exemplo, nos contratos de trabalho e nos contratos de consumo.

A já referida intervenção do Estado nas relações privadas foi respaldada pela Constituição Federal, sobretudo diante dos objetivos e fundamentos da República Federativa do Brasil, passando a autonomia da vontade a receber limitações, de forma que alguns autores sustentam a sua substituição pela chamada "autonomia privada". Nesse sentido, Giovanni Ettore Nanni enfatiza que

[...] a autonomia privada é circundada de limites não apenas ideológicos mas reais e jurídicos, impostos para garantir que as relações jurídicas sejam revestidas daqueles aspectos já citados que decorrem da constitucionalização do direito civil, tais como a liberdade, a justiça social, a igualdade e a solidariedade. ${ }^{26}$

O Código Civil de 2002, atento às modificações ideológicas pelas quais passou o Estado, de Liberal para Social, alterou a redação do antigo artigo 85 do código anterior, estipulando no artigo 112 que: "Nas declarações de vontade se atenderá mais à intenção nelas consubstanciada do que ao sentido literal da linguagem". Inseriu o legislador, portanto, as palavras "nelas consubstanciada" à redação do artigo correspondente no Código de $1916^{27}$, de modo que não basta a vontade, mas uma vontade que deverá estar consubstanciada em uma declaração, o que implica uma objetivação na relação negocial, ou seja, uma superação do subjetivismo.

Ainda, como reflexo da socialidade, o Código Civil prevê uma limitação ao acordo

${ }^{25}$ ROCHA, Silvio Luís Ferreira da. Princípios contratuais. In: NANNI, Giovanni Ettore (Coord.). Temas relevantes do direito civil contemporâneo: estudos em homenagem ao Professor Renan Lotufo. São Paulo: Atlas, 2008. p. 515.

26 NANNI, Giovanni Ettore. A evolução do Direito Civil obrigacional: a concepção do Direito Civil constitucional e a transição da autonomia da vontade para a autonomia privada. In: LOTUFO, Renan (Coord.). Cadernos de autonomia privada. Curitiba: Juruá, 2011. p. 173.

${ }^{27}$ Art. 85. Nas declarações de vontade se atenderá mais à sua intenção que ao sentido literal da linguagem. 
de vontades quando deste resultar um desequilíbrio decorrente da alteração das circunstâncias, o que possibilitará a revisão dos contratos, conforme se analisará na sequência.

\subsection{PRINCÍPIO DA OBRIGATORIEDADE}

Pelo princípio da obrigatoriedade entende-se que o contrato vincula as partes, obrigando-as a cumprir o avençado, sob pena de sujeitarem-se à sua execução forçada. Este princípio está relacionado à necessidade de satisfação da segurança jurídica e materializa-se no dogma pacta sunt servanda, ou seja, os contratos devem ser cumpridos.

O Código Civil francês, como já mencionado, em seu artigo 1.134, chegou a equiparar os contratos à lei. Segundo Jeová Santos ${ }^{28}$, o critério remontaria a Rousseau, autor do Contrato Social, o qual considerava "que as convenções eram a base de toda autoridade legítima entre os homens". Nesta seara, Emmanuel Kant também afirmava: "Quando alguém decide algo com respeito a outro, é sempre possível que cometa certa injustiça, porém toda injustiça é impossível quando decide para si mesmo". ${ }^{29}$

Também o artigo $1.372^{\mathbf{3 0}}$ do Código Civil italiano, o artigo $1.197^{\mathbf{3 1}}$ do Código Civil argentino e o artigo $1.091^{32}$ do Código Civil espanhol ${ }^{33}$ dispuseram de forma semelhante.

Entretanto, conforme a função social dos contratos, princípio adotado pelo Código Civil vigente, bem como diante da necessidade de manutenção de um equilíbrio na relação contratual, o princípio da obrigatoriedade sofrerá uma mitigação e, excepcionalmente, o contrato poderá ser modificado, quando, por exemplo, houver a superveniência de um fato

\footnotetext{
${ }^{28}$ SANTOS, Antonio Jeová. Função social: lesão e onerosidade excessiva nos contratos. São Paulo: Método, 2002. p. 36-37.

${ }^{29}$ Loc. cit.

${ }^{30}$ Tradução livre da autora: Art. 1.372. O contrato tem força de lei entre as partes.

31 Tradução livre da autora: Art. 1.197. As convenções feitas nos contratos formam para as partes uma regra à qual devem submeter-se como à própria lei.

32 Tradução livre da autora: art. 1.091. As obrigações que nascem dos contratos têm força de lei entre as partes contratantes e devem cumprir o seu teor.

${ }^{33}$ Posteriormente, em 2009, foi elaborada uma proposta de modernização do Código Civil espanhol, elaborada pela Comissão Geral de Codificação (N. da A.). Nesta proposta, o artigo 1.213 teria a seguinte redação: "Si las circunstancias que sirvieron de base del contrato hubieren cambiado de forma extraordinaria e imprevisible durante su ejecución de manera que ésta se haya hecho excesivamente onerosa para una de las partes o se haya frustrado el fin del contrato, el contratante al que, atendidas las circunstancias del caso y especialmente la distribución contractual o legal de riesgos, no le sea razonablemente exigible que permanezca sujeto al contrato, podrá pretender su revisión, y si ésta no es posible o no puede imponerse a una de las partes, podrá aquél pedir su resolución. La pretensión de resolución sólo podrá ser estimada cuando no quepa obtener de la propuesta de revisión ofrecidas por cada una de las partes una solución que restaure la reciprocidad de intereses del contrato". (Disponível em: http://www.mjusticia.gob.es/cs/Satellite/es/1215198250781/Detalle.html>. Acesso em: 14 abr. 2013).
} 
que modifique "o estado de fato contemporâneo à celebração do contrato e torne excessivamente oneroso o seu cumprimento.",34

Desta forma, o princípio da obrigatoriedade do contrato sofreu importante modificação (ou relativização), especialmente após a I Guerra Mundial, que trouxe "profundas alterações econômicas e sociais que distorciam flagrantemente a Justiça comutativa nos contratos celebrados". 35

O mesmo se deu com a II Guerra Mundial, ao passo que ganharam força as teorias da cláusula rebus sic stantibus, "da imprevisão", da "pressuposição", da "base negocial”,36, sobre as quais se arrazoará separadamente.

\subsection{PRINCÍPIO DA RELATIVIDADE DOS CONTRATOS}

Adotado pelo Código Civil francês, em seu artigo $1.165^{37}$, o qual prevê que "As convenções só têm efeitos entre as partes contratantes; elas não prejudicam terceiros e só lhes trazem benefícios nos casos previstos pelo artigo 1.121", entende-se que, pelo princípio da relatividade dos contratos, produzem-se efeitos apenas entre as partes contratantes. $\mathrm{O}$ princípio decorre do adágio romano res inter alios acta tertio nec nocet nec prodest, ou seja, “o negócio realizado entre outros não prejudica, nem aproveita terceiro".

Entretanto, o princípio da função social dos contratos acabou por alterar o conteúdo do princípio da relatividade, pois o contrato, tomando contornos de socialidade, poderá eventualmente refletir na esfera de terceiros. Parafraseando Antonio Junqueira de Azevedo, é possível afirmar que a função social do contrato visa impedir tanto os contratos que tragam prejuízos à coletividade - como ocorre com os contratos de consumo -, quanto os contratos que prejudiquem ilicitamente pessoas determinadas. $\mathrm{O}$ autor afirma: "O antigo princípio da relatividade dos efeitos contratuais precisa, pois, ser interpretado, ou re-lido, conforme a Constituição".38

${ }^{34}$ ROCHA, Silvio Luís Ferreira da. Princípios contratuais. In: NANNI, Giovanni Ettore (Coord.). Temas relevantes do direito civil contemporâneo: estudos em homenagem ao Professor Renan Lotufo. São Paulo: Atlas, 2008. p. 511-512.

${ }^{35}$ FERREIRA, Durval. Erro negocial - objecto - motivos - base negocial e alterações de circunstâncias. Coimbra: Almedina, 1998. p. 9.

${ }^{36}$ Loc. cit.

${ }^{37}$ No original em francês: "Les conventions n'ont d'effet qu'entre les parties contractantes; elles ne nuisent point au tiers, et elles ne lui profitent que dans le cas prévus par l'article 1.121".

${ }^{38}$ AZEVEDO, Antonio Junqueira de. (Parecer). Os princípios do atual direito contratual e a desregulamentação do mercado. Direito de exclusividade nas relações contratuais de fornecimento. Função social do contrato e responsabilidade aquiliana do terceiro que contribui para inadimplemento contratual. In: pareceres de direito privado. São Paulo: Saraiva, 2004, p. 141. Estudos e 
A relatividade dos contratos também recebe mitigações nos chamados contratos oponíveis a terceiros, os quais admitem a oposição do terceiro quando o contrato alheio à sua pessoa causa-lhe um prejuízo digno de proteção. Sílvio Luís Ferreira da Rocha exemplifica: o credor que tenha seus interesses afetados por contrato que o seu devedor venha a firmar com terceiro, que diminua o patrimônio do devedor, que "era a garantia do credor de que receberia o seu crédito". De acordo com o autor, "presentes certos requisitos, o credor terá a possibilidade de pedir a ineficácia do contrato em relação à sua pessoa, na hipótese de fraude de execução, ou a invalidação do contrato, na hipótese de fraude contra credores".39

A doutrina especializada menciona como mitigação ao princípio da relatividade do contrato a chamada "eficácia social" do contrato, também no sentido de impor a responsabilidade a terceiro de não violar obrigação contratual alheia que lhe seja, ou deva ser, do conhecimento, conforme se analisará no princípio da função social do contrato. O contrato, uma vez condicionado à função social, passa a ser oponível erga omnes, isto é, "todos têm o dever de se abster da prática de atos (inclusive a celebração de contratos) que saibam prejudiciais ou comprometedores da satisfação de créditos alheios". ${ }^{40}$

\subsection{PRINCÍPIO DA BOA-FÉ}

Em se tratando de contratos, não podemos olvidar a inclusão do princípio da boa-fée ${ }^{\mathbf{4 1}}$ no rol dos princípios da moderna teoria contratual, principalmente ao se considerar a concepção dinâmica da relação obrigacional, tal como foi preconizada por Clóvis do Couto e Silva, segundo a qual a obrigação é concebida como um processo, em que se objetiva "sublinhar o ser dinâmico da obrigação, as várias fases que surgem no desenvolvimento da relação obrigacional e que entre si se ligam com interdependência”. ${ }^{2}$

O Código Civil brasileiro de 1916 não fazia menção à boa-fé relacionada aos negócios jurídicos na sua Parte Geral; entretanto, foi inserida no Código Civil vigente, em seu artigo 113, quando prevê que os negócios jurídicos devem ser interpretados de acordo com a

\footnotetext{
39 ROCHA, Silvio Luís Ferreira da. Princípios contratuais. In: NANNI, Giovanni Ettore (Coord.). Temas relevantes do Direito Civil contemporâneo: estudos em homenagem ao Professor Renan Lotufo. São Paulo: Atlas, 2008. p. 512.

${ }^{40}$ NEGREIROS, Teresa. Teoria do contrato: novos paradigmas. Rio de Janeiro: Renovar, 2002. p. 241.

${ }^{41}$ Identifica-se a origem da boa-fé na fides romana, termo de significado não muito claro, que abrangia três dimensões (fides-sacra, fides-fato e fides-ética) (SAMPAIO, Laerte Marrone de Castro. A boa-fé objetiva na relação contratual. Barueri: Manole, 2004. p. 25).

${ }^{42}$ COUTO E SILVA, Clóvis Veríssimo do. A obrigação como processo. Rio de Janeiro: FGV, 2011. p. 10.
} 
boa-fé e os usos do lugar da sua celebração. ${ }^{43}$

Também o artigo 187 faz menção à boa-fé ao referenciar que "Também comete ato ilícito o titular de um direito que, ao exercê-lo, excede manifestamente os limites impostos pelo seu fim econômico ou social, pela boa-fé ou pelos bons costumes". ${ }^{4}$

O artigo 422 do Código Civil/2002 prevê que "Os contratantes são obrigados a guardar, assim na conclusão do contato, como em sua execução, os princípios de probidade e boa-fé". O Código de Defesa do Consumidor (Lei 8.078 de 1990), no seu artigo $4^{\circ}$, tratou da Política Nacional de Relações de Consumo, a qual tem

[...] por objetivo o atendimento das necessidades dos consumidores, o respeito à sua dignidade, saúde e segurança, a proteção de seus interesses econômicos, a melhoria da sua qualidade de vida, bem como a transparência e harmonia das relações de consumo

Dentre os princípios contemplados no artigo $4^{\circ}$, do Código de Defesa do Consumidor está a

[...] harmonização dos interesses dos participantes das relações de consumo e compatibilização da proteção do consumidor com a necessidade de desenvolvimento econômico e tecnológico, e modo a viabilizar os princípios nos quais se funda a ordem econômica (art. 170 da Constituição Federal), sempre com base na boa-fé e equilíbrio nas relações entre consumidores e fornecedores.

Ainda no Código de Defesa do Consumidor, o artigo 51, inciso IV, considera como cláusulas abusivas aquelas que "estabeleçam obrigações consideradas iníquas, abusivas, que coloquem o consumidor em desvantagem exagerada ou sejam incompatíveis com a boa-fé ou a equidade".

A concepção da relação obrigacional como processo contrapõe-se à concepção da relação obrigacional como um vínculo estático, resultante da soma do crédito e do débito. A concepção estática da relação obrigacional visualiza como vínculo, basicamente, o seu aspecto externo, que é definido pelos seus elementos: sujeitos, objeto e o vínculo de sujeição que liga o devedor ao credor. ${ }^{45}$

\footnotetext{
${ }^{43}$ Há que se ressaltar, entretanto, que a boa-fé fora contemplada primeiramente no Código Comercial de 1850, no artigo 131, inciso I ("A inteligência simples e adequada, que for mais conforme à boa-fé, e ao verdadeiro espirito e natureza do contrato, deverá sempre prevalecer à rigorosa e restrita significação das palavras"). (GOMES, Orlando. Contratos. Rio de Janeiro: Forense, 2007. p. 43-44).

${ }^{44}$ Dispositivo semelhante ao contido no Código Civil brasileiro contém o Código Civil italiano, em seu artigo 1.366, o qual prevê: "O contrato deve ser interpretado segundo a boa-fé".

${ }^{45}$ MARTINS-COSTA, Judith. A boa-fé no direito privado. São Paulo: Revista dos Tribunais, 1999. p. 394.
} 
Por outro lado, segundo Clóvis do Couto e Silva ${ }^{46}$, a concepção dinâmica da obrigação abrangeria "todos os direitos, inclusive os formativos, pretensões e ações, deveres (principais e secundários dependentes e independentes), obrigações, exceções, e, ainda, posições jurídicas".

No mesmo sentido, Mário Júlio de Almeida Costa ensina que

[...] numa compreensão globalizante da situação jurídica creditícia, apontam$\mathrm{se}$, ao lado dos deveres de prestação - tanto deveres principais de prestação, como deveres secundários -, os deveres laterais (<<Nebenplifchten $\rangle)$, além de direitos potestativos, sujeições, ónus jurídicos, expectativas jurídicas, etc. Todos os referidos elementos se coligam em atenção a uma identidade de fim e constituem o conteúdo de uma relação de carácter unitário e funcional: a relação obrigacional complexa, ainda designada relação obrigacional em sentido amplo ou, nos contratos, relação contratual. $^{47}$

Para elucidar esta formulação, Judith Martins-Costa cita os chamados deveres de informação, afirmando não ser possível exaurir-se o seu conteúdo, sua intensidade, nem a situação em que se revelam, além do que tais deveres decorreriam de exigências do tráfico jurídico-social viabilizados pela boa-fé objetiva. ${ }^{48}$

Essa concepção implica um declínio do dogma da vontade, elevando a boa-fé a uma fonte de obrigação. Assim, a boa-fé, em sua concepção objetiva, é considerada como uma reação ao individualismo exacerbado que dominou o pensamento do mundo jurídico, e que também vigorava no ordenamento jurídico brasileiro no momento em que entrou em vigor o Código Civil anterior.

Com o surgimento do Estado Social, em detrimento do Estado Liberal, o conceito de boa-fé nas relações negociais sofreu modificações, passando de subjetiva para objetiva, trazendo em seu conceito toda uma carga de solidariedade, de cooperação, de justiça e de eticidade.

A boa-fé subjetiva, também chamada "boa-fé psicológica", ou "boa-fé crença", denota um estado de consciência ou convencimento individual de obrar em conformidade ao direito, o que, segundo Judith Martins-Costa, alude a ideia de ignorância, de crença errônea, ainda que escusável, acerca da existência de uma situação regular. ${ }^{49}$ Por outro lado, de acordo com a autora, a boa-fé objetiva é fundada "na honestidade, na retidão, na lealdade e,

\footnotetext{
${ }^{46}$ COUTO E SILVA, Clóvis Veríssimo do. A obrigação como processo. Rio de Janeiro: FGV, 2011. p. 8.

${ }^{47}$ COSTA, Mário Júlio de Almeida. Direito das obrigações. 9. ed. Coimbra: Almedina, 2003. p. 63. (destaques no original).

${ }^{48}$ SAMPAIO, Laerte Marrone de Castro. A boa-fé objetiva na relação contratual. Barueri: Manole, 2004. p. 25.

${ }^{49}$ MARTINS-COSTA, Judith. A boa-fé no direito privado. São Paulo: Revista dos Tribunais, 1999. p. 411.
} 
principalmente, na consideração para com os interesses do "alter", visto como um membro do conjunto social que é juridicamente tutelado". 50

Segundo Orlando Gomes, a boa-fé objetiva corresponde a uma "regra de conduta, um modelo de comportamento social, algo, portanto, externo em relação ao sujeito". 51 Exige, além do elemento interno (subjetivo) de o contratante julgar estar agindo de acordo com procedimentos condizentes com a boa-fé (padrões razoáveis de conduta), um plus exterior. Enquanto isto, na boa-fé subjetiva ${ }^{52}$, somente o elemento interno é suficiente. ${ }^{53}$ Já segundo Teresa Negreiros ${ }^{\mathbf{5 4}}$, a boa fé-objetiva consiste em um "dever de conduta contratual ativo", ou seja, obriga a parte a praticar um determinado comportamento ao invés de outro; exige colaboração e cooperação "com consideração dos interesses um do outro, em vista de se alcançar o efeito prático que justifica a existência jurídica do contrato celebrado”.

Laerte Marrone de Castro Sampaio $^{55}$ sustenta que a boa-fé objetiva é uma ponte entre os mundos ético e jurídico e que, certamente, com a inserção da boa-fé na Parte Geral do Código Civil pretendeu o legislador trazer à tona o princípio de eticidade que informa $\mathrm{o}$ código vigente e já mencionado anteriormente.

De acordo com Cláudia Lima Marques ${ }^{\mathbf{5 6}}$, a boa-fé impõe aos contratantes (portanto, tanto ao devedor, quanto ao credor)

[...] uma atuação "refletida", uma atuação refletindo, pensando no outro, no parceiro contratual, respeitando-o, respeitando seus interesses legítimos, suas expectativas razoáveis, seus direitos, agindo com lealdade, sem abuso, sem obstrução, sem causar lesão ou desvantagem excessiva.

Essa cooperação teria por objetivo atingir o cumprimento do contrato e, consequentemente, a realização dos interesses das partes contratantes.

Para Judith Martins-Costa, o significado da valoração a ser procedida mediante a boa-fé objetiva não pode ser feito a priori, “dependendo sempre das concretas circunstâncias do caso". 57 Através da inserção da cláusula geral da boa-fé, houve um rompimento com a concepção de que todos os problemas surgidos pudessem encontrar fácil subsunção nas

\footnotetext{
${ }^{50}$ MARTINS-COSTA, Judith. A boa-fé no direito privado. São Paulo: Revista dos Tribunais, 1999. p. 412.

${ }^{51}$ GOMES, Orlando. Contratos. Rio de Janeiro: Forense, 2007. p. 43.

${ }^{52}$ Ressalta-se que o Código Civil de 2002, em inúmeros artigos faz menção, ainda, à boa-fé sob uma perspectiva subjetivista. É o que ocorre, por exemplo, com o artigo 1201, que prevê: "É de boa-fé a posse, se o possuidor ignora o vício, ou o obstáculo que impede a aquisição da coisa”.

${ }^{53}$ FACHIN, Luiz Edson. Repensando fundamentos de direito privado. São Paulo: Renovar, 1998. p. 197.

${ }^{54}$ NEGREIROS, Teresa. Teoria do contrato: novos paradigmas. Rio de Janeiro: Renovar, 2002. p. 122.

${ }^{55}$ SAMPAIO, Laerte Marrone de Castro. A boa-fé objetiva na relação contratual. Barueri: Manole, 2004. p. 27.

${ }^{56}$ MARQUES, Cláudia Lima. Contratos no Código de Defesa do Consumidor. São Paulo: RT, 2002. p. 107.

${ }^{57}$ MARTINS-COSTA, Judith. Op. cit., p. 412.
} 
disposições legais contidas no ordenamento jurídico. Atribuem-se ao juiz maiores poderes interpretativos, facilitando que uma mesma previsão legal possa se adaptar às novas realidades sociais.

Não se diga que a inserção da cláusula geral da boa-fé, que tem seu significado semântico aberto, atribuiria ao juiz um arbítrio. Ao contrário, o juiz, ao decidir o caso concreto, deverá pautar-se por critérios objetivos, procedendo "a comparações com grupos de hipóteses já decididas anteriormente pela jurisprudência ou pela doutrina"; ainda, considerando o comportamento standard, ou seja, o comportamento padrão, qual seja aquele observado pelo homem médio, do bom pai de família, que age de maneira normal e razoável dentro da situação sub judice. ${ }^{\mathbf{5 8}}$

\subsubsection{As funções do Princípio da Boa-Fé}

De acordo com a doutrina ${ }^{\mathbf{5 9}}$, a boa-fé objetiva possui algumas funções: 1) cânone hermenêutico-integrativo; 2) norma de criação de deveres jurídicos; 3) norma de limitação ao exercício de direitos subjetivos; 4) corretiva.

Primeiramente, a boa-fé seria considerada um cânone hermenêutico-integrativo, diante da necessidade de se suprirem as lacunas ocorridas na relação obrigacional, bem como de interpretá-la. Neste sentido, Clóvis do Couto e Silva já ensinava: "não se pode recusar a existência de relação entre a hermenêutica integradora e o princípio da boa-fé" ${ }^{60}$

Também em relação à função interpretativa, a boa-fé agiria de forma a auxiliar na determinação do significado negocial, tomando-se por base o sentido objetivo, haja vista que indagações de ordem psicológica quanto ao querer das partes não se mostram razoáveis no mundo moderno, onde as relações são massificadas.

Deve-se tutelar a confiança que o comportamento de uma das partes gerou, a não ser que o destinatário da declaração tenha ciência da real intenção do declarante ${ }^{\mathbf{6 1}}$, pois, nesta hipótese, este não teria qualquer expectativa frustrada. Assim, para a determinação do significado negocial, devem ser analisadas todas as circunstâncias relevantes que o declaratário pode conhecer.

Laerte Marrone ensina que, no caso em que o sentido objetivo do contrato suscitar dúvidas, há que se preferir o significado que a boa-fé indique como o mais razoável, e que, na

\footnotetext{
${ }^{58}$ SAMPAIO, Laerte Marrone de Castro. A boa-fé objetiva na relação contratual. Barueri: Manole, 2004. p. 33.

${ }^{59}$ Entre eles: MARTINS-COSTA, Judith. Op. cit. SAMPAIO, Laerte Marrone de Castro. Op. cit.

${ }^{60}$ COUTO E SILVA, Clóvis Veríssimo do. A obrigação como processo. Rio de Janeiro: FGV, 2011. p. 32.

${ }^{61}$ SAMPAIO, Laerte Marrone de Castro. Op. cit., p. 40.
} 
perquirição do sentido que mais se amolde à boa-fé, deve o intérprete lançar mão de algumas regras hauridas da jurisprudência, tais como: optar por uma interpretação que resulte na preservação do contrato (princípio da conservação); favorecer-se a parte que assumiu a obrigação; interpretação contra o predisponente, notadamente nos contratos de adesão. ${ }^{\mathbf{6 2}}$

Sob o aspecto da integração, a boa-fé suprirá as lacunas deixadas pelas partes que podem, até mesmo por imprevidência, não ter disciplinado todos os aspectos relevantes relacionados ao negócio firmado. Surge, então, a boa-fé como forma de colmatar as lacunas.

Mônica Yoshizato Bierwagen exemplifica a função integrativa da boa-fé com uma hipótese de supermercado que encomenda ovos de Páscoa, mas deixa de fixar data para a entrega. De acordo com a boa-fé objetiva, o fornecedor não pode, sob alegação de que a nãodesignação da data lhe permite determinar a data da entrega, fazê-la após a festividade, tendo em vista que é previsível que o comprador necessita dos ovos, para vender em seu comércio, naquela oportunidade. ${ }^{63}$

Por vezes, para que o contrato possa produzir efeitos, tornam-se exigíveis às partes comportamentos que não estão contidos em cláusulas contratuais, nem em expressa e cogente disposição legal, mas que são essenciais à "própria salvaguarda da fattispecie contratual e à plena produção dos efeitos correspondentes ao programa contratual objetivamente posto". ${ }^{64}$

A boa-fé objetiva teria, então, a função de criação de deveres jurídicos, eis que implica a observância de deveres que extrapolam os deveres principais ou deveres primários de prestação (exemplo, entregar a coisa e pagar o preço na compra e venda, ou a cessão de uso e pagamento de aluguel na locação), quais sejam: os deveres secundários e os deveres laterais, anexos ou instrumentais que variam conforme o caso concreto, ficando a cargo tanto do devedor quanto do credor. ${ }^{65}$

Tais deveres não estão orientados ao cumprimento da prestação ou dos deveres principais, mas, antes, referem-se "à satisfação dos interesses globais envolvidos, em atenção a uma identidade finalística, constituindo o complexo conteúdo da relação que se unifica funcionalmente". ${ }^{66}$ É nesse aspecto que se materializa a solidarização do contrato. ${ }^{67}$

Os deveres secundários dividem-se em: 1) deveres meramente acessórios da obrigação principal, que se destinam a preparar o cumprimento ou assegurar a prestação

\footnotetext{
${ }^{62}$ SAMPAIO, Laerte Marrone de Castro. A boa-fé objetiva na relação contratual. Barueri: Manole, 2004. p. 51.

${ }^{63}$ BIERWAGEN, Mônica Yoshizato. Princípios e regras de interpretação dos contratos no Novo Código Civil. São Paulo: Saraiva, 2003. p. 55.

${ }^{64}$ MARTINS-COSTA, Judith. A boa-fé no direito privado. São Paulo: Revista dos Tribunais, 1999. p. 429.

65 Ibid., p. 437-438.

${ }^{66}$ Ibid., p. 440.

${ }^{67}$ SAMPAIO, Laerte Marrone de Castro. Op. cit., p. 53.
} 
principal; 2) deveres secundários com prestação autônoma.

Os deveres acessórios da obrigação principal que se destinam a preparar o cumprimento ou assegurar a prestação principal podem ser exemplificados nos seguintes: dever de embalar a coisa vendida, dever de promover o seu transporte com segurança. ${ }^{\mathbf{6 8}}$

Os deveres secundários com prestação autônoma revelam-se como verdadeiros sucedâneos da obrigação principal, como ocorre com o dever de indenizar, resultante da impossibilidade culposa da prestação ou o dever de garantir a coisa, mediante a prestação de garantia autônoma. ${ }^{69}$

José Carlos Moreira da Silva Filho entende que os deveres secundários subdividemse em prestações sucedâneas do dever primário de prestação, que apontam para o surgimento de deveres a partir do descumprimento, como o dever de indenizar e o de restituição, e em prestações coexistentes com a prestação principal, em que o dever de prestação não é substituído, mas em virtude de um mau cumprimento, gerado pela mora ou defeito na prestação principal, nasce outro dever paralelo, como o de indenização ou de abatimento do preço no caso de deterioração da coisa. ${ }^{\mathbf{7 0}}$

Já os deveres instrumentais, laterais ou anexos são ditos “deveres de cooperação e proteção dos recíprocos interesses" e são exemplificativamente os deveres de cuidado, previdência e segurança, os deveres de aviso e esclarecimento.

Segundo Menezes Cordeiro, o dever de esclarecimento obriga as partes, na vigência do contrato que as une, a informarem-se mutuamente de todos os aspectos atinentes ao vínculo, de ocorrências que, com ele, tenham certa relação e, ainda, de todos os efeitos que da execução contratual possam advir. ${ }^{71}$

O dever de esclarecimento dirige-se ao outro participante da relação jurídica e tem como objeto uma declaração de conhecimento. Exemplifica-se: o dever do advogado de aconselhar o seu cliente acerca das melhores possibilidades de cada via judicial passível de escolha para a satisfação de seu objetivo; o do médico, de esclarecer o paciente sobre a relação custo/benefício do tratamento escolhido, ou dos efeitos colaterais do medicamento indicado; ou, ainda, na fase pré-contratual, do sujeito que entre em negociações, de avisar o futuro contratante sobre os fatos que podem ter relevo na formação da declaração negocial.

\footnotetext{
${ }^{68}$ MARTINS-COSTA, Judith. A boa-fé no direito privado. São Paulo: Revista dos Tribunais, 1999. p. 438.

${ }^{69}$ Loc. cit.

${ }^{70}$ SILVA FILHO, José Carlos Moreira da. Hermenêutica filosófica e Direito: o exemplo privilegiado da boa-fé objetiva no direito contratual. Rio de Janeiro: Lumen Juris, 2003. p. 296.

${ }^{71}$ CORDEIRO, António Menezes. A boa-fé no Direito Civil. Coimbra: Almedina, 1984. p. 605. (Colecção Teses, v. 1, T. II).
} 
Ainda, como deveres laterais, considerem-se os deveres de informação, os deveres de proteção e cuidado com a pessoa e patrimônio da contraparte, os deveres de omissão, sigilo ou segredo. ${ }^{\mathbf{7 2}}$

Segundo Menezes Cordeiro, em razão do dever de proteção, "considera-se que as partes, enquanto perdure um fenômeno contratual, estão ligadas a evitar que, no âmbito desse fenômeno, sejam infligidos danos mútuos, nas suas pessoas ou nos seus patrimônios".73

O Tribunal de Justiça do Estado de São Paulo condenou promitente vendedor de lotes situados em área preservada a indenizar os promissários compradores por desrespeito ao dever acessório de esclarecimento, considerando que, sendo a área protegida por normas relativas ao meio ambiente, isto inviabilizaria a demarcação e o arruamento. ${ }^{74} \mathrm{O}$ dever de sigilo "exige reserva da parte sobre o que tenha sabido em razão do contrato e cuja divulgação lhe possa frustrar o objetivo ou trazer prejuízo a seu desenvolvimento e, por conseguinte, à própria contraparte". ${ }^{75} \mathrm{De}$ acordo com a doutrina ${ }^{76}$, a violação a um dever lateral poderá ensejar a resolução do contrato.

É de se ressaltar que o dever de agir de boa-fé deve ser observado não apenas por ocasião da formação de um contrato, mas também na fase das tratativas ou negociações preliminares, durante a sua execução e, até mesmo, após a sua extinção (no sentido de cumprimento dos deveres primários inerentes ao contrato); e sua incidência não pode ser afastada entre os contratantes, sendo, portanto, irrenunciável. Portanto, a boa-fé exige que as partes somente iniciem as tratativas quando estejam efetivamente interessadas na celebração do negócio e possuam condições legais e econômicas de firmar futuro contrato. $^{77}$

A título de exemplo, o Tribunal de Justiça do Rio Grande do Sul já impôs a estabelecimento comercial o dever de indenizar cliente que teve seu veículo furtado em estacionamento da empresa, ainda que um contrato entre ambos não tenha chegado a existir, o que representou um verdadeiro reflexo da aplicação da boa-fé durante as

\footnotetext{
${ }^{72}$ MARTINS-COSTA, Judith. A boa-fé no direito privado. São Paulo: Revista dos Tribunais, 1999. p. 438.

${ }^{73}$ CORDEIRO, António Manuel da Rocha e Menezes. A boa-fé no Direito Civil. Coimbra: Almedina, 1984. p. 604. (Colecção Teses, v. 1, T. II).

${ }^{74}$ Embargos Infringentes n. 9176178-45.2000.8.26.0000. Rel. Theodureto Camargo, Comarca de São Paulo, $8^{\mathrm{a}}$ Câmara de Direito Privado, j. 27.10.2010.

${ }^{75}$ GODOY, Claudio Luiz Bueno de. A função social do contrato: os novos princípios contratuais. 3. ed. São Paulo: Saraiva, 2009. p. 80.

${ }^{76}$ Nesse sentido: Laerte Marrone de Castro Sampaio. A boa-fé objetiva na relação contratual. Barueri: Manole, 2004.; SILVA FILHO, José Carlos Moreira da. Hermenêutica filosófica e Direito: o exemplo privilegiado da boa-fé objetiva no direito contratual. Rio de Janeiro: Lumen Juris, 2003.

${ }^{77}$ SAMPAIO, Laerte Marrone de Castro. A boa-fé objetiva na relação contratual. Barueri: Manole, 2004. p. 65.
} 
tratativas. $^{\mathbf{7 8}}$

Como mencionado há pouco, até mesmo em fase posterior à extinção do contrato é possível falar-se em deveres laterais impostos às partes, no sentido de não prejudicar o fim contratual, "abstendo-se o contraente de praticar condutas que frustrem as legítimas expectativas derivadas do contrato para a outra parte". ${ }^{79}$

Como deveres laterais pós-contratuais, exemplifica-se: a) o dever do sócio que deixa a sociedade não prejudicar, com a sua atividade, o funcionamento da pessoa jurídica que integrou, revelando circunstância que só podia saber em razão da sua qualidade de sócio; b) a obrigação do empregado de, cessado o vínculo empregatício, silenciar sobre um segredo de fabricação, não o repassando a uma empresa concorrente; c) o dever do advogado de guardar os documentos de seu cliente; d) a obrigação do fornecedor de manter a oferta de peças de reposição; e) a necessidade de o fornecedor informar sobre as novas descobertas acerca da periculosidade do produto; f) estar o empregador adstrito a fornecer informações corretas sobre o empregado idôneo; g) o dever do fornecedor de explicar o funcionamento de uma máquina de tipo novo; h) o dever de não concorrência. ${ }^{\mathbf{8 0}}$

Para Luiz Edson Fachin, o dever de cooperação exige de ambos os contratantes uma postura de solidariedade. ${ }^{\mathbf{8 1}}$ A boa-fé exerceria, ainda, a função de limite ao exercício de direitos subjetivos. Laerte Marrone de Castro Sampaio cita algumas hipóteses de limitação ao exercício desses direitos, entre as quais podem-se citar: a) venire contra factum proprium, que expressa a ideia de que a parte não pode agir em contradição a um comportamento assumido anteriormente. Exemplificando: o credor que concordou, durante a execução do contrato de prestações periódicas, com o pagamento em lugar e tempo diferente do convencionado, não pode surpreender o devedor com a exigência literal do contrato ${ }^{\mathbf{8 2}}$; b) suppressio, que representa a situação do direito que, não tendo sido, em certas circunstâncias, exercido durante um determinado lapso temporal, não possa mais sê-lo por, de outra forma, contrariarse a boa-fé. É o que ocorre com o comprador que, não retirando a mercadoria, pretenda compelir o vendedor a guardar os bens por prazo indeterminado; c) surrectio, que seria o

\footnotetext{
${ }^{78}$ Apelação Cível n. 598.209.179, rel. Des. Helena Cunha Vieira, j. em 19.08.1998.

${ }^{79}$ SAMPAIO, Laerte Marrone de Castro. A boa-fé objetiva na relação contratual. Barueri: Manole, 2004. p. 69.

${ }^{80}$ Loc. cit.

${ }^{81}$ FACHIN, Luiz Edson. Repensando fundamentos de direito civil brasileiro contemporâneo. São Paulo: Renovar, 1998. p. 198.

${ }^{82}$ ACIDENTE NO TRABALHO - SEGURO DE VIDA EM GRUPO - TENOSSINOVITE - DOENÇA PREEXISTENTE. A seguradora que aceita o contrato e recebe durante anos as contribuições da beneficiária do seguro em grupo não pode recusar o pagamento da indenização quando comprovada a invalidez, sob a alegação de que a tenossinovite já se manifestara anteriormente. Recurso conhecido e provido (ARJ, $4^{\mathrm{a}}$ Turma, REsp. 258805/MG, Rel. Min. Ruy Rosado de Aguiar, j. 21.09.2000).
} 
"reverso da suppressio", pois, ao contrário de obviar o exercício de um direito, serve a criar outro, diante do comportamento da pessoa ${ }^{\mathbf{8 3 , 8 4}}$; d) tu quoque, que exprime a ideia de ser vedado à pessoa que viole uma norma jurídica a invocação posterior desta norma em seu favor; e) adimplemento substancial do contrato, que implica a proteção do contraente que cumpriu quase a totalidade da prestação a que estava adstrito; f) exercício desequilibrado de direito, que ocorre na situação em que se divisa uma manifesta desproporção entre a vantagem obtida como exercício de um direito pelo seu titular e o sacrifício imposto pelo devedor. É o que ocorre na hipótese de despedida de um trabalhador prestes a adquirir estabilidade; g) na cobrança de débitos em que se exponha o devedor ao ridículo.

Para elucidar a hipótese de limitação ao exercício de direitos subjetivos em decorrência do cumprimento substancial do contrato, Martins-Costa cita julgado do Tribunal de Justiça do Rio Grande do Sul, que julgou improcedente a ação de rescisão de escritura pública contra um casal que comprou um imóvel, mediante contrato contendo uma cláusula de pacto comissório, por não efetuar o pagamento da última parcela. Por outro lado, foi julgada ação consignatória desta última parcela. Em seu voto, entendeu o relator que:

A ação de rescisão de contrato improcede porque a compradora cumpriu substancialmente a sua obrigação, não podendo ser o atraso na última prestação causa justificadora para a resolução do negócio, assim como pretendido na inicial. O desfazimento caracterizaria gravíssima injustiça, desatendendo a uma exigência do moderno direito das obrigações, onde pontifica o princípio do adimplemento substancial, segundo o qual o cumprimento próximo do resultado final exclui o direito de resolução, facultando apenas o pedido de adimplemento e o de perdas e danos; 'mas não se permitiria o pedido de resolução, se essa pretensão viesse a ferir o princípio da boa-fé' (Prof. Clóvis do Couto e Silva, Estudos de Direito Civil Brasileiro e Português, p. 56-57). "Portanto, ainda que a compradora efetivamente tivesse voluntariamente deixado de pagar a última prestação, assim como alegado na petição inicial, e estivesse em mora, ainda assim a ação improcederia, cabendo apenas à vendedora haver a reparação dos danos porventura sofridos. É preciso ficar bem claro que a parêmia dura lex, sed lex, cedeu lugar à necessidade de decidir-se com razoabilidade as situações em concreto, pois o compromisso maior do Estado de Direito é com a justiça. A mim parece profundamente injusto, e até imoral, alguém receber inúmeras prestações de um contrato de execução prolongada e depois, pelo simples atraso da última parcela, vir a juízo brandir a cláusula de pacto comissório, pretendendo desfazer o negócio e recuperar a propriedade do imóvel, que, por força de política econômica, então vigente, valorizou-se

${ }^{83}$ GODOY, Claudio Luiz Bueno de. A função social do contrato: os novos princípios contratuais. 3. ed. São Paulo: Saraiva, 2009. p. 91.

${ }^{84}$ Exemplo de Menezes Cordeiro: sociedade que, por mais de vinte anos, com o acordo unânime dos sócios, procedeu à distribuição de lucros não correspondente ao pacto social que só poderia ser alterado com certas formalidades. "O BGH, atentas as circunstâncias, entendeu que a distribuição não oficial deveria ser mantida para o futuro". (CORDEIRO, António Manoel da Rocha e Menezes. A boa-fé no Direito Civil. Coimbra: Almedina, 1984. p. 822. (Colecção Teses, v. 1, T. II). 
muito acima de outros bens. ${ }^{85}$

Há autores que sustentam que, a par das funções hermenêutico-integrativa, criadoras de deveres e limitadoras do exercício de direitos subjetivos, a boa-fé teria ainda uma função corretiva, sendo responsável por garantir uma relação de equilíbrio entre a prestação e a contraprestação nos contratos comutativos; para outros autores, entre os quais Fernando Noronha, tal função corretiva estaria relacionada a outro princípio contratual, qual seja o princípio da justiça contratual.

Segundo Castro Sampaio, forte no pensamento de Franz Wieacker, a manutenção da equivalência econômica entre a prestação e a contraprestação é uma função do princípio da boa-fé objetiva. ${ }^{86} \mathrm{O}$ autor sintetiza:

[...] o fato é que o direito contratual atual está impregnado pela idéia de solidariedade. Dessa forma, ele não tolera que a vontade das partes, sem nenhuma peia, conduza a situações manifestamente desiguais, em que a relação entre prestação e contraprestação mostre-se desequilibrada. ${ }^{87}$

\subsection{PRINCÍPIO DA FUNÇÃO SOCIAL DO CONTRATO}

Miguel Reale, ao tratar do (ainda) projeto do Código Civil vigente, atribuía ao "sentido social uma das características mais marcantes do Projeto, em contraste com o sentido individualista que condiciona o Código Civil de 1916", mencionando o princípio da socialidade como informador do novo codex. ${ }^{\mathbf{8 8}}$

Neste diapasão, foi inserido no texto do Código Civil de 2002 o artigo 421, que prevê que "A liberdade de contratar será exercida em razão e nos limites da função social do contrato".

A relevância da função social do contrato está, de acordo com Claudio Luiz Bueno de Godoy, na promoção daqueles objetivos do Estado Social, na eficácia dos valores básicos do ordenamento. ${ }^{\mathbf{8 9}}$ Há que se ressaltar que, analisando-se o trabalho legislativo que antecedeu a aprovação do Projeto do Código Civil, Tancredo Neves apresentou uma Emenda (de n. ${ }^{\circ}$ 371) objetivando suprimir o referido artigo 421, sob o argumento de que o conceito de função

\footnotetext{
${ }^{85}$ MARTINS-COSTA, Judith. A boa-fé no direito privado. São Paulo: Revista dos Tribunais, 1999. p. 458-459. (destaques no original).

${ }^{86}$ SAMPAIO, Laerte Marrone de Castro. A boa-fé objetiva na relação contratual. Barueri: Manole, 2004. p. 85.

${ }^{87}$ Ibid., p. 87.

${ }^{88}$ REALE, Miguel. O projeto do novo Código Civil. São Paulo: Saraiva, 1999. p. 7.

${ }^{89}$ GODOY, Claudio Luiz Bueno de. A função social do contrato: os novos princípios contratuais. 3. ed. São Paulo: Saraiva, 2009. p. 156.
} 
social era impreciso e que, em consequência desta imprecisão, a liberdade de contratar, que é fundamental dentro do regime da livre iniciativa, ficaria atingida. ${ }^{\mathbf{9 0}}$

Carlos Alberto Goulart Ferreira propõe um conceito de função social do contrato: "consiste na finalidade pela qual visa o ordenamento jurídico a conferir aos contratantes medidas ou mecanismos jurídicos capazes de coibir qualquer desigualdade dentro da relação contratual". Este autor afirma ainda que a função social do contrato repousa na "harmonia entre a autonomia privada e a solidariedade social".91

Atribui-se, assim, à função social do contrato, assim como à boa-fé, como mencionado acima, a qualidade de uma cláusula geral ${ }^{\mathbf{9 2}}$ inserida no Código Civil, permitindo uma constante evolução doutrinária e jurisprudencial, conforme se modifiquem a realidade fática e as ideologias vigentes.

De acordo com Humberto Theodoro Júnior, o princípio da função social não se volta para o relacionamento entre as partes contratantes, mas para os reflexos do negócio jurídico perante terceiros, isto é, no meio social, diferenciando-se da boa-fé pelo fato de que esta fica restrita ao relacionamento travado entre os próprios sujeitos do negócio jurídico. ${ }^{\mathbf{9 3}} \mathbf{9 4}$

Claudio Luiz Bueno de Godoy, entretanto, sustenta que a "função social atua sempre quando presente estejam interesses meta-individuais, mas também interesse individual relativo à dignidade da pessoa humana. Ou seja, a função social atuando, primeiro, inter partes". ${ }^{95}$ De acordo com o autor, a possibilidade de o contrato produzir efeitos em relação a terceiros consiste na chamada "eficácia social” do contrato. ${ }^{\mathbf{9 6}}$

Alguns exemplos em que a função social do contrato não foi observada são citados por Theodoro Júnior.: a) induzir a massa de consumidores a contratar a prestação ou aquisição de certo serviço ou produto sob influência de propaganda enganosa; b) alugar quartos de prédio residencial, transformando-o em pensão; c) alugar imóvel em zona residencial para fins comerciais incompatíveis com o zoneamento da cidade; d) praticar atos de concorrência

\footnotetext{
${ }^{90}$ SANTOS, Antonio Jeová. Função social: lesão e onerosidade excessiva nos contratos. São Paulo: Método, 2002. p. 112-113.

91 FERREIRA, Carlos Alberto. Equilíbrio contratual. In: LOTUFO, Renan (Coord.). Direito Civil Constitucional. São Paulo: Max Limonad, 1999. p. 112-113.

${ }^{92}$ MARTINS-COSTA, Judith. A boa-fé no direito privado. São Paulo: Revista dos Tribunais, 1999. p. 351.

93 THEODORO JÚNIOR., Humberto. O contrato e sua função social. Rio de Janeiro: Forense, 2004. p. 13.

${ }^{94}$ Segundo Theodor Júnior, "não se pode falar em desvio de função social, quando um contratante, deslealmente, provoca prejuízo ao outro, empregando meios reprováveis ética e juridicamente, ou prevalecendo da inexperiência ou da necessidade em que o contratante se encontra. Nesse plano, que é típico da boa-fé objetiva, quem pode reagir á apenas o sujeito contratual lesado. $O$ fenômeno se passa no plano interno do relacionamento negocial" (THEODORO JÚNIOR, Humberto. Op. cit., p. 57).

95 GODOY, Claudio Luiz Bueno de. A função social do contrato: os novos princípios contratuais. 3. ed. São Paulo: Saraiva, 2009. p. 177.

${ }^{96}$ Ibid., p. 177.
} 
desleal; d) qualquer negócio de disposição de bens em fraude de credores. ${ }^{97}$

A doutrina trata da eficácia social do contrato também no sentido de impor a responsabilidade a terceiro de não violar obrigação contratual alheia que lhe seja ou deva ser do conhecimento, como ocorre, por exemplo, no casos de atores e esportistas ligados a uma determinada empresa ou clube serem, na vigência de seus contratos, assediados por terceiros, os quais, malferindo a avença de que são cientes, procuram cooptá-los a uma nova contratação, ou, ainda, na hipótese de funcionários que retiravam veículos da fábrica a preços subsidiados, com a vedação de revendê-los, por certo tempo, mas que eram comprados, antes disso, por terceiros (cientes da restrição), para se aproveitarem do menor preço. ${ }^{\mathbf{9 8}}$

A necessidade de observância das limitações constitucionais à liberdade de contratar, além de acarretar uma relativização a pacta sunt servanda ${ }^{99}$ (hoje, certamente condicionada, mas não suprimida, sob pena de enveredarmos para o caos), implica modificações também no âmbito da relatividade dos contratos, pois o contrato não mais está limitado às partes, "transcendendo e outorgando uma função social frente a toda a sociedade". 100

No mesmo sentido é o posicionamento de Teresa Negreiros, ao sustentar que a função social constitui um fundamento para a responsabilização de um terceiro que contribui para o descumprimento de uma obrigação originária de um contrato do qual não seja parte, configurando-se a chamada "tutela externa do crédito". A autora afirma, ainda, que o princípio da função social condiciona o exercício da liberdade contratual e torna o contrato, como situação jurídica merecedora de tutela, oponível erga omnes, isto é,

[...] todos têm o dever de se abster da prática de atos (inclusive a celebração de contratos) que saibam prejudiciais ou comprometedores da satisfação de créditos alheios. A oponibilidade do contrato traduz-se, portanto, nesta obrigação de não fazer, imposta àquele que conhece o conteúdo de um contrato, embora dele não seja parte. ${ }^{101}$

A função social do contrato, nas palavras de Giovanni Ettore Nanni, não apenas reduz a força obrigatória dos contratos, mas também impõe um "padrão de comportamento

\footnotetext{
${ }^{97}$ THEODORO JÚNIOR, Humberto. O contrato e sua função social. Rio de Janeiro: Forense, 2004. p. 55.

${ }^{98}$ GODOY, Claudio Luiz Bueno de. A função social do contrato: os novos princípios contratuais. 3. ed. São Paulo: Saraiva, 2009. p. 185.

99 Para Carneiro Maia, "O apótema pacta sunt servanda tornou-se flexível, perdeu seu absolutismo, débil à penetração das idéias (sic) de sentido solidarista e ao intervencionismo estatal nas relações econômicas" (MAIA, Paulo Carneiro. Da cláusula rebus sic stantibus. São Paulo: Saraiva, 1959. p. 15-16).

100 NANNI, Giovanni Ettore. A evolução do Direito Civil obrigacional: a concepção do Direito Civil constitucional e a transição da autonomia da vontade para a autonomia privada. In: LOTUFO, Renan (Coord.). Cadernos de autonomia privada. Curitiba: Juruá, 2001. p. 187.

${ }^{101}$ NEGREIROS, Teresa. Teoria do contrato: novos paradigmas. Rio de Janeiro: Renovar, 2002. p. 264.
} 
com o intuito de evitarem-se relações obrigacionais espoliativas e injustas", ${ }^{102}$

Todos estes institutos - função social do contrato, boa-fé objetiva, objetivização dos contratos, lesão, estado de perigo, onerosidade excessiva - servem para demonstrar a queda do dogma da vontade, havendo uma transição da autonomia da vontade para a autonomia privada. ${ }^{103}$ Certamente, entretanto, deve-se compreender que a função social do contrato não está relacionada à concepção do contrato como instrumento de assistência social à custa do patrimônio alheio, haja vista que o contrato é um instituto que tem fins econômicos. Desta forma, uma vez estipulado o contrato de maneira clara, isento de dúvidas, ausente qualquer vício de consentimento, estipulando as prestações a serem cumpridas pelas partes, não poderá o magistrado, a pretexto de fazer com que o contrato atinja a sua função social, modificá-lo para que o preço, por exemplo, seja correspondente ao produto adquirido.

Não se trata, como mencionado por Reale, da vitória do socialismo, mas sim do triunfo da socialidade. ${ }^{104}$

Segundo Zeno Veloso, a função social do contrato impõe que a força normativa das cláusulas e estipulações esteja submetida a imperativos éticos e "não pode se prestar a abusos, servir de instrumento de exploração dos ricos e poderosos com relação aos menos favorecidos, a serviço de ambições desmedidas do capitalismo selvagem, que a todo poder tem de ser reprimido". ${ }^{105}$

\subsection{PRINCÍPIO DO EQUILÍBRIO CONTRATUAL}

A teoria contratual clássica preocupava-se em tutelar uma manifestação de vontade livre, buscando a proteção à liberdade e à igualdade em sua concepção formal, de forma que, ainda que a relação negocial fosse espoliativa, ela deveria manter-se em razão da obrigatoriedade do contrato.

Entretanto, conforme já mencionado, com o passar do tempo, sobretudo após as grandes guerras mundiais, a necessidade de proteção à dignidade da pessoa humana mostrouse imperiosa e o Estado passou a intervir paulatinamente nas relações negociais, a fim de evitar relações espoliativas. Institutos até então dormentes, tais como a lesão e a possibilidade

\footnotetext{
102 NANNI, Giovanni Ettore. A evolução do Direito Civil Obrigacional: a concepção do Direito Civil constitucional e a transição da autonomia da vontade para a autonomia privada. In: LOTUFO, Renan (Coord.). Cadernos de autonomia privada. Curitiba: Juruá, 2001. p. 185.

103 Ibid., p. 168.

${ }^{104}$ REALE, Miguel. O projeto do novo Código Civil. São Paulo: Saraiva, 1999. p. 7.

${ }^{105}$ VELOSO, Zeno. Invalidade do negócio jurídico: nulidade e anulabilidade. Belo Horizonte: Del Rey, 2002. p. 14.
} 
de revisão por onerosidade excessiva, voltaram a ser valorizados nos mais diversos ordenamentos jurídicos.

O Código Civil Brasileiro de 1916, na esteira da teoria clássica e do liberalismo, não fez menção alguma à lesão ou à onerosidade excessiva. Em 1990, o Código de Defesa do Consumidor, através do artigo $6^{\circ}, \mathrm{V}$, já previa a proteção do consumidor, possibilitando a modificação das cláusulas contratuais que estabeleçam prestações desproporcionais, ou sua revisão, em razão de fatos supervenientes, que as tornem excessivamente onerosas.

Posteriormente, em 2002, com a entrada em vigor do Código Civil, o legislador contemplou, nos artigos 156 e 157, o estado de perigo e a lesão, e nos artigos 478 a 480, a onerosidade excessiva.

Perante o ideal liberalista, a justiça contratual era formal, ou seja,

[...] pressupunha que do contrato decorreria uma equivalência, porque, em tese, era assegurada a igualdade entre as partes no momento da contratação. Portanto, estando estas acordes e no gozo das plenas faculdades mentais, decorreria daí a justiça da avença. ${ }^{106}$

Conforme citado, a vontade era considerada a mola propulsora dos negócios jurídicos e, com o consenso, a justiça contratual era presumida. Para elucidar esse entendimento, analise-se expressão consagrada de Foullié: “quem se diz contratante se diz justo". 107

Como menciona Fernando Rodrigues Martins,

[...] para o Estado liberal, a equivalência das prestações era indiferente ao sistema, porque ganhar muito ou perder tudo fazia parte do livre jogo liberal do contrato, com a concepção social a equivalência objetiva das prestações retorna ao programa das disciplinas contratuais como princípio de justiça. ${ }^{108}$

No Estado social, o contrato passa a ser "objeto da justiça comutativa, cabendo a proteção do equilíbrio contratual entre as partes, assim como a tutela em face de qualquer fato exterior que possa mitigar ou pôr em risco o sinalagma". ${ }^{109}$

Objetivando disciplinar os conflitos de interesses que surgem em razão de um desequilíbrio contratual, inúmeras teorias foram elaboradas, entre as quais a Teoria da Pressuposição, de Windscheid, a Teoria da Base Subjetiva do Negócio Jurídico, de Paul

\footnotetext{
${ }^{106}$ MARTINS, Fernando Rodrigues. Princípio da justiça contratual. São Paulo: Saraiva, 2009. p. 105.

${ }^{107}$ Ibid., p. 90.

${ }^{108}$ Ibid., p. 105.

${ }^{109}$ Ibid., p. 32.
} 
Oertmann, Teoria da Base Objetiva do Negócio Jurídico, de Karl Larenz, e inúmeras outras, sobre as quais se discorrerá oportunamente. Imprescindível também é a análise da histórica cláusula rebus sic stantibus, a qual será abordada no capítulo que segue. 


\section{CAPÍTULO III \\ A CLÁUSUla REBUS SIC STANTIBUS}

\subsection{CLÁUSULA REBUS SIC STANTIBUS - HISTÓRICO}

É necessária a realização de um escorço histórico sobre a cláusula rebus sic stantibus desde a Antiguidade, para que se possa melhor compreender o equilíbrio contratual na atualidade, ressaltando-se, desde já, a necessidade de diferenciá-la da teoria da imprevisão.

Enquanto a cláusula rebus sic stantibus preocupa-se de forma mais objetiva com a alteração das circunstâncias iniciais que poderiam implicar

[...] alteração da própria equivalência das prestações contratuais, a teoria da imprevisão, em sua conformação a partir da I Guerra Mundial, ofereceu, de forma mais subjetiva, grande destaque à própria imprevisibilidade do evento futuro superveniente, ainda que se trate de um "subjetivismo objetivado". ${ }^{110}$

Nesse sentido, Nelson Borges ${ }^{111}$ ensina que a referida cláusula está relacionada à “alteração da base negocial pura e simples, isto é, os efeitos produzidos pelo evento anormal". Por outro lado, a teoria da imprevisão teria a própria "imprevisão" como causadora da alteração da base econômica. Ou seja, a cláusula rebus estaria contida na teoria da imprevisão, mas o contrário não ocorreria.

Anísio José de Oliveira, entretanto, não distingue a cláusula rebus sic stantibus da teoria da imprevisão. ${ }^{112}$

\subsubsection{Na Antiguidade}

A Antiguidade Oriental já tinha suas codificações. Entre elas, está a primeira codificação expressa de que se tem notícia, o Código de Ur-Namu, datado de 2050 a.C. Posteriormente, cerca de 1930 a.C, surgiram as Leis de Esnunna, os Códigos Lipit-Ischtar,

\footnotetext{
${ }^{110}$ CUNHA, Wladimir Alcibíades Marinho Falcão. Revisão judicial dos contratos: do Código de Defesa do Consumidor ao Código Civil de 2002. São Paulo: Método, 2007. p. 184.

${ }^{111}$ BORGES, Nelson. A teoria da imprevisão no Direito Civil e no Processo Civil. São Paulo: Malheiros, 2002. p. 79.

OLIVEIRA, Anísio José de. A teoria da imprevisão nos contratos. São Paulo: Universitária de Direito, 2002. p. 92.
} 
datado de 1840 a.C, e o Código de Hamurabi, de data controvertida ${ }^{113}$, que foi encontrado apenas no início do século $\mathrm{XX}^{114}$.

Alguns autores, como Othon Sidou ${ }^{115}$ e Rogério Ferraz Donnini ${ }^{116}$ sustentam que a revisão dos contratos encontra suas raízes mais remotas na codificação mesopotâmica, citando a Lei 48 de Hamurabi, Rei da Babilônia, a qual previa:

Se alguém tem um débito a juros, e uma tempestade devasta o seu campo ou destrói a colheita, ou por falta d'água não cresce o trigo no campo, ele não deverá nesse ano dar trigo ao credor, deverá modificar sua tábua de contrato e não pagar juros por esse ano.

A existência ou não de técnicas revisionais dos contratos no Direito Romano é controversa. Nelson Borges ${ }^{117}$, por exemplo, sustenta que é nele que se encontra a semente da moderna cláusula rebus sic stantibus, sendo as primeiras referências à sua essência, qual seja, a permanência das coisas em seu estado de criação, passíveis de serem encontradas nos escritos de Cícero, Sêneca e Polybios (150 a.C). Giuseppe Osti ${ }^{118}$, entretanto, afirma que, inicialmente, a cláusula tinha um conteúdo moral e que, no campo jurídico, sua infiltração foi lenta.

Cícero, em trecho do De officiis ad Marcum filium, declara que há promessas que às vezes não podem ser cumpridas e pactos que não podem ser pactuados, a exemplo do advogado que não será descumpridor da promessa de patrocinar uma causa se, no intertempo, lhe adoece um filho. Da mesma forma, um homem em estado lúcido que tenha feito o depósito de sua espada e venha a se tornar louco não poderá ser considerado um depositário infiel se o depositário negar-lhe a restituição da coisa, mas que, "ao contrário, serias culpado se a restituísses". Por fim, menciona o depósito de uma quantia, a que o depositante que “toma arma contra a pátria" pede a restituição. Não deve o depositário devolver, sabendo que

\footnotetext{
${ }^{113}$ Há relatos de que surgiu por volta de 1694 a.C, 2000 a.C, 2.700 a.C, entre outras datas (BORGES, Nelson. A teoria da imprevisão no Direito Civil e no Processo Civil. São Paulo: Malheiros, 2002. p. 85).

${ }^{114} \mathrm{O}$ referido código foi encontrado na cidade de Susa, na Pérsia, pelo arqueólogo Jacques Morgan. Foi talhado em diorito negro, medindo $2,25 \mathrm{~m}$ de altura, $1,70 \mathrm{~m}$ de circunferência e $2 \mathrm{~m}$ de base, com mais de 280 leis. Atualmente, encontra-se no Museu do Louvre, em Paris (BORGES, Nelson. Op. cit., p. 84).

${ }^{115}$ SIDOU, J. M. Othon. A revisão judicial dos contratos e outras figuras jurídicas. A Cláusula "Rebus Sic Stantibus". Dos Efeitos da Fiança. Empresa Individual de responsabilidade limitada. Rio de Janeiro: Forense, 1978. p. 1.

${ }^{116}$ DONNINI, Rogério Ferraz. A revisão dos contratos no Código Civil e no Código de Defesa do Consumidor. 2. ed. São Paulo: Saraiva, 2001. p. 14.

${ }^{117}$ BORGES, Nelson. Op. cit., 85.

${ }^{118}$ OSTI, Giuseppe. Scritti Giuridici. Milano: Giuffrè, 1973. p. 184.
} 
aquele "iria servir-se do dinheiro para agir contra a república". ${ }^{119}$

Polybios, por exemplo, em um discurso, afirmou que

Se a situação agora ainda fosse a mesma do que antes, na altura em que vós concluístes a aliança com os Aetólios, então deveriam decidir-se a manter firme o vosso convênio pois a isso vos teríeis obrigado; caso ela esteja, contudo, totalmente modificada, então ser-vos-á justificado retomar, sem quaisquer dúvidas, a questão. ${ }^{120}$

Sêneca ${ }^{121}$, por sua vez, propôs em seu De Beneficiis que a ruptura superveniente de um contrato poderia ser considerada lícita ante a alteração das circunstâncias. Afirmou que:

\begin{abstract}
A menor mudança deixa-me inteiramente livre para modificar minha determinação, desobrigando-se da promessa. Prometi-vos minha assistência de advogado: porém, verifiquei que sua pretendida ação era contra meu pai. prometi-vos acompanhar em viagem: certifiquei-me, ao depois, que ladrões infestavam a estrada; prometi-vos patrocínio: no entanto meu filho adoeceu ou minha mulher é acometida de dores de parto. Todas essas coisas devem estar na mesma situação que a do momento em que vos prometi, para que possais reclamar essa promessa como obrigatória. Ora, que maior mudança pode advir do que a certeza adquirida por mim desde que vos tornastes um homem maldoso e ingrato? O que vos prometi como a uma pessoa que o merecesse, recusar-vos-ei por indigno, e ainda poderei me lastimar de ter sido enganado.
\end{abstract}

Carneiro Maia ${ }^{122}$, por seu turno, afirma que a origem da cláusula rebus sic stantibus não pode ser atribuída aos juristas romanos porque sua estruturação não ocorreu no direito romano. Nelson Borges, amparado no pensamento de Eugène Bruzin, afirma que, se os romanos chegaram a focalizar o problema oriundo de mudanças na base contratual, talvez tenha sido em esporádicos casos especiais, já que as poucas soluções ali apresentadas se ressentem da falta de metodologia rígida e ordenamento sistematizado. ${ }^{123}$

Entretanto, muitos doutrinadores ${ }^{124,125}$ entendem que, embora a cláusula rebus sic

${ }^{119}$ SIDOU, J. M. Othon. A cláusula “Rebus sic stantibus” no Direito Brasileiro. Rio de Janeiro: Freitas Bastos, 1962. p. 2.

120 CORDEIRO, António Manoel da Rocha e Menezes. A alteração das circunstâncias e o pensamento sistemático. Coimbra: Almedina, 1999. p. 938.

121 RODRIGUES JÚNIOR, Otavio Luiz. Revisão judicial dos contratos. Autonomia da vontade e teoria da imprevisão. São Paulo: Atlas, 2006. p. 34.

122 MAIA, Paulo Carneiro. Da cláusula rebus sic stantibus. São Paulo: Saraiva, 1959. p. 36.

${ }^{123}$ BORGES, Nelson. A teoria da imprevisão no Direito Civil e no Processo Civil. São Paulo: Malheiros, 2002. p. 89.

${ }^{124}$ Neste sentido: FONSECA, Arnoldo Medeiros da. Caso fortuito e teoria da imprevisão. Rio de Janeiro: Forense, 1958. p. 194.

125 Otavio Luiz Rodrigues Júnior tem entendimento contrário: “[...] entende-se que, mesmo inexistindo em Roma a célebre parêmia, é inegável sua contribuição para o que se veio a tornar a cláusula rebus sic stantibus na 
stantibus tenha sido aplicada pelos romanos de forma assistemática, na verdade ali havia o império da regra pacta sunt servanda. Isto porque o direito Romano "era formalista, individualista e, sobretudo, absolutista. Daí a premissa de que, uma vez assumida a obrigação, deveria ser cumprida, mesmo com prejuízos para o adimplente, em obediência ao apotegma: $o$ contrato faz lei entre as partes". ${ }^{126}$

Reconhece-se, entretanto, que os precursores no reconhecimento dos elementos da justiça comutativa existente no emprego do princípio no campo estritamente jurídico podem ser encontrados nos escritos de Paulus, Africanus e Neratius.

No Digesto do Corpus Iuris de Justiniano, Neratius teria cunhado a frase: Contractus qui habent tractum successivum et dependentiam de futuro, rebus sic stantibus intelliguntur $^{127}$, frase que, reduzida à sua essência, passou a ser conhecida como rebus sic stantibus $^{128}$. Neratius afirmou (Digesto, XII.4.8):

O que Sérvio escreveu no livro dos dotes, que se entre as pessoas que contraíram núpcias uma delas não tivesse atingido a idade legal, pode ser restituído; o que, entretanto, lhe fora dado a título de dote, assim deve ser entendido, sobrevindo o divórcio antes que ambas as pessoas tenham a idade legal, dever ser feita a restituição daquele dinheiro; porém, permanecendo no mesmo estado matrimonial, não é possível mais a restituição, também daquilo que a esposa haja dado ao esposo a título de dote, tanto que perdure entre eles a afinidade; porque aquilo que se dá por esta causa, não se tendo consumado todavia a conjunção carnal, como era preciso que houvesse a fim de que se chegasse a constituir o dote, ou enquanto isso possa vir a suceder, não haverá restituição. ${ }^{129}$

Africanus, por sua vez, teria escrito (Digesto, XLVI.3.38pr.):

Quando alguém tiver estipulado que se dê a ele ou a Tício, se diz ser mais certo que se há de entender, que se paga bem a Tício, somente se perdurar o mesmo estado em que se falava quando se assentou a estipulação; mas, se foi por doação, ou tiver sido desterrado, ou se pôs interdição pela água e pelo fogo, ou foi feito servo, se há de dizer que não se lhe paga bem, porque se considera que tacitamente é inerente à estipulação esta convenção, desde que permaneça no mesmo estado. ${ }^{130}$

Idade Média" (RODRIGUES JÚNIOR, Otavio Luiz. Revisão judicial dos contratos. Autonomia da vontade e teoria da imprevisão. São Paulo: Atlas, 2006. p. 37).

${ }^{126}$ BORGES, Nelson. A teoria da imprevisão no Direito Civil e no Processo Civil. São Paulo: Malheiros, 2002. p. 90.

${ }^{127}$ Em tradução livre da autora: Contratos que têm trato sucessivo ou dependem do futuro devem conservar sua base de contratação inicial.

${ }^{128}$ BORGES, Nelson. Op. cit., p. 88.

${ }^{129}$ RODRIGUES JÚNIOR, Otavio Luiz. Op. cit., p. 35.

${ }^{130}$ MAIA, Paulo Carneiro. Da cláusula rebus sic stantibus. São Paulo: Saraiva, 1959. p. 43. 


\title{
3.1.2 Na Idade Média
}

Há um consenso na doutrina no sentido de que entre o início da Era Cristã até meados do século XIII, não há registro de utilização da cláusula rebus sic stantibus, a qual somente seria retomada na Idade Média.

Atribui-se ao medievo as glórias pela criação das bases da teoria da imprevisão ${ }^{131}$, difundindo-a primeiramente pelas mãos dos filósofos católicos e, posteriormente, dos juristas do direito canônico, bem como nas decisões dos tribunais eclesiásticos, consolidando-se no trabalho dos pós-glosadores.

A Igreja Católica atingiu grande importância durante a Idade Média, de forma que a moral vigente era assentada na Doutrina Cristã, a qual também influenciou o direito. Entre os mais importantes canonistas encontravam-se São Tomás de Aquino, Santo Agostinho e Graciano.

São Tomás de Aquino, por exemplo, em sua Suma Teológica, tratava da mentira ao retratar o fato de que São Paulo ${ }^{132}$, que prometera visitar os habitantes da cidade de Coríntio, decidiu adiar a visita, por força de ofensas ali sofridas. Ele teria afirmado:

\begin{abstract}
Quem promete uma coisa, com intenção de cumprir a promessa, não mente, porque não fala contra o que tem na mente. Mas, não a cumprindo, é-lhe infiel, mudando de intenção. Pode, porém, ser escusado por duas razões: primeiro, se prometeu o que é manifestamente ilícito, pecou quando assim procedeu e, portanto, age bem mudando de propósito; segundo, se mudaram as condições das pessoas e dos atos, pois, como diz Sêneca, para estarmos obrigados a fazer o que prometemos, é necessário que todas as circunstâncias permaneçam as mesmas. Do contrário, não mentimos quando prometemos, nem somos infiéis à promessa por não cumpri-la, pois já as condições não eram as mesmas. Por isso o Apóstolo não mentiu por não ter ido a Corinto, como prometera, pois obstáculos supervenientes lho impediram. $^{133}$
\end{abstract}

Relativamente à lesão, o filósofo já assentava que as trocas econômicas não poderiam fugir da ideia de justiça comutativa, considerando como pecado a usura. ${ }^{134}$ Entretanto, alguns registros dão conta de que, séculos antes, Santo Agostinho já tratava da mentira nos seus Sermones ad Populum (Sermão n. 33), onde escreveu:

\footnotetext{
${ }^{131}$ BORGES, Nelson. A teoria da imprevisão no Direito Civil e no Processo Civil. São Paulo: Malheiros, 2002. p. 36.

${ }^{132}$ Segunda Epístola aos Coríntios, capítulo primeiro, versículos 17-20 e 23-24.

${ }^{133}$ BORGES, Nelson. Op. cit., p. 97.

${ }^{134}$ CUNHA, Wladimir Alcibíades Marinho Falcão. Revisão judicial dos contratos: do Código de Defesa do Consumidor ao Código Civil de 2002. São Paulo: Método, 2007. p. 153.
} 
Quando ocorre alguma coisa de maior importância que impeça a execução fiel da minha promessa eu não quis mentir, mas apenas não pude cumprir o que prometi. Eis, então, o que penso, sem argumentação forçada para persuadir-vos, porém, agucei a atenção de vossa prudência para a circunstância de que não mente aquele que promete alguma coisa e não a faz se, para isto não executar, algo sucedeu que impediu o cumprimento da promessa, ao contrário da falsidade convincente. ${ }^{135}$

No século XII, Graciano, professor da Escola de Direito de Bolonha, afirmava:

[...] se alguém recebe uma espada e promete restituir quando solicitado por aquele que fez a entrega dela; se porventura aquele que reclama sua espada veio a enlouquecer, está claro que se não deve restituí-la para que se não mate a si ou aos outros, até que recupere a sanidade mental. ${ }^{136}$

Foi por intermédio de um Decreto de Graciano que surgiu a primeira menção à cláusula rebus sic stantibus. $^{137}$

No século XIII, surge a Escola dos Pós-Glosadores, também conhecida por comentadores ou bartolistas, liderada por Bartolo de Sassoferrato, que deu grande importância à cláusula rebus sic stantibus. Entre outros adeptos estavam Baldo, Tiraquello, Juan de Andrea e Giason del Mayo. ${ }^{138}$

Segundo Borges, a essência do pensamento bartolista consubstanciava-se na concepção de que "a cláusula deveria ser sempre considerada tácita, subentendida em qualquer contrato, desde que tivesse trato sucessivo, ou dependesse do futuro, como exigia a antiga fórmula romana", apoiando-se no fato de que "a concordância das partes só poderia ir até o ponto de manter o convencionado enquanto vigentes as circunstâncias que cercaram seu nascimento". 139

Entretanto, Bartolo foi criticado por ter generalizado de forma temerária a aplicação da cláusula a qualquer modificação da base contratual ${ }^{140}$, não demonstrando "qualquer preocupação com a estruturação jurídica, perfil doutrinário, ou mesmo com o conteúdo e

\footnotetext{
${ }^{135}$ Sermones ad Populum, Sermão 133, in J. P. Migne Editorem, t. 38, 1865, p. 738 (MAIA, Paulo Carneiro. Da cláusula rebus sic stantibus. São Paulo: Saraiva, 1959. p. 35).

${ }^{136}$ RODRIGUES JÚNIOR, Otavio Luiz. Revisão judicial dos contratos. Autonomia da vontade e teoria da imprevisão. São Paulo: Atlas, 2006. p. 39.

${ }^{137}$ OSTI, Giuseppe. Scritti Giuridici. Milano: Giuffrè, 1973. p. 188.

${ }^{138}$ BORGES, Nelson. A teoria da imprevisão no Direito Civil e no Processo Civil. São Paulo: Malheiros, 2002. p. 99.

${ }^{139}$ Ibid., p. 101.

${ }^{140}$ Loc. cit.
} 
efeitos da cláusula rebus sic stantibus". ${ }^{141}$

\subsubsection{Na Idade Moderna}

Andreas Alciato (1482-1550), precursor da Scuola Culta, elaborou o primeiro enunciado estruturado sobre a cláusula rebus sic stantibus. Em sua obra Opera Omnia, ao tentar disciplinar o instituto, procurou limitar o uso da cláusula às situações em que as partes não podiam ter previsto o evento extraordinário. ${ }^{142}$

Alciato esclareceu que, nos atos unilaterais, ou dependentes da vontade de uma só pessoa, a mudança de vontade é sempre lícita, ao passo que nos atos bilaterais a modificação volitiva não o seria a não ser que: a vontade primitiva decorresse de erro; o próprio contrato assim o disponha; a lei ou ambas as partes concordem com a rescisão ou revogação, e, por fim, sobrevenha "alguma causa que não foi considerada na conclusão do ajuste, e se o fosse, um pelo menos dos contraentes não teria concordado com obrigar-se". ${ }^{143},{ }^{144}$

Osti atribui a Coccejo (1699) a primeira tentativa de construção teórica completa da cláusula rebus sic stantibus, considerando a amplitude da matéria em relação à qual a cláusula se aplica: não sobre todos os negócios, mas sobre todas as relações jurídicas - pessoais ou reais; de direito público ou de direito privado. Coccejo havia notado a indeterminação da palavra res e a necessidade de melhor definir e classificar os elementos em que, de fato, a

${ }^{141}$ CUNHA, Wladimir Alcibíades Marinho Falcão. Revisão judicial dos contratos: do Código de Defesa do Consumidor ao Código Civil de 2002. São Paulo: Método, 2007. p. 180.

${ }^{142}$ BORGES, Nelson. A teoria da imprevisão no Direito Civil e no Processo Civil. São Paulo: Malheiros, 2002. p. 104.

${ }^{143}$ SIDOU, J. M. Othon. A cláusula “Rebus sic stantibus” no Direito Brasileiro. Rio de Janeiro: Freitas Bastos, 1962. p. 14.

${ }^{144} \mathrm{Na}$ língua originária: "L'Alciato há dettati per definire l'influenza dei mutamenti dello stato di fatto sull'efficacia degli atti volontarii: quando è decisiva la volontà di un solo, condizione di persistenza per l'efficacia dell'atto, è la persistenza ti tutti gli elementi di fatto che concorsero in modo insurrogabile - o apparentemente tale - alla determinazione di quella volontà; quando il negocio trae vita dalla combinazione di due volontà diverse, è necessario, a distruggerlo, che sopravvenga alcunchè di estraneo all'ámbito del consenso, non solo, ma la cui assenza sia presupposta dal contenuto del consenso medesimo: a parte il caso in cui la modificazione così influente sia solo soggettiva, e cioè che nuove circostanze dimostrino che il consenso fu solo apparente (errore), secondo Alciato, appunto, un tale carattere e una tale efficacia ai mutamenti dello stato di fatto si può riconoscere solo se esse risulti dalla natura giuridica stessa del contratto, o se, pu non risultando logicamente da questa, la legge la consideri normale, data la natura economica dell'atto, e come normalmente contenuta nella volontà delle parti essa stessa la sancisca, o se, infine, l'effetto risultante sia così lontano da quello solitamente prevedibile, che debba secondo la comune coscienza ritenersi estraneo in modo assoluto al contenuto del consenso. E - si noti bene, poichè ciò è interessante ai fini della nostra ricerca queste norme, in quanto dipendono dalla struttura logica del consenso, non volgono, nella generalità loro, per l'una categoria o specie di contratti, meglio che per l'altra: esse si applicano indifferentemente a tutti $i$ negozi bilaterali, a ogni atto discendente < <ex voluntate duorum>>”. (OSTI, Giuseppe. Scritti Giuridici. Milano: Giuffrè, 1973. p. 199 - destacado no original). 
modificação pode ser levada em consideração. ${ }^{145}$

O princípio reitor da teoria de Coccejo estava na presunção de estabilidade volitiva no tempo, de forma que a cláusula rebus sic stantibus seria útil em situações excepcionais, “marcadas pela identificação de erro no consentimento, por um permissivo legal ou mesmo quando assim o requeresse a natureza da avença" e quando surgisse uma causa superveniente e não considerada, sobre a qual as partes não se haviam precatado.

No século XVII, Hugo Grotius, considerado o fundador do moderno jusnaturalismo, e Augustin Leyser atribuíram à cláusula uma posição de maior dignidade, incorporando-a em seus estudos sobre o Direito Natural e o Direito Internacional. ${ }^{146}$ Grotius tratou da cláusula desdobrando-se sobre o argumento da interpretação restritiva. ${ }^{147}$ Para Grotius, as promessas devem ser cumpridas, "não se devendo pressupor que elas estariam sujeitas às condições tácitas sob as quais foram acordadas. Apenas se os negócios se tornassem excessivamente onerosos é que poderiam as partes se desobrigarem do que pactuaram". ${ }^{148}$

Em meados do século XVIII, a cláusula entrou em período de decadência, de forma que até o início do século XIX, com o princípio da autonomia da vontade fortalecido, fortalecida também estava a regra pacta sunt servanda. Durante este período, a cláusula rebus sic stantibus tinha valor meramente histórico.

No Código Civil da Baviera, de 1756, está redigida a primeira norma legislativa, adotando a cláusula rebus sic stantibus. Segundo Osti, três princípios limitativos da cláusula são contidos no código bávaro, a saber: 1) que a modificação das circunstâncias não seja atribuída nem à mora, nem à culpa do devedor; 2) que não seja fácil prever a circunstância modificativa; 3) que a modificação seja de tal natureza que, se o devedor a tivesse previsto, segundo a opinião desinteressada e honesta das pessoas inteligentes, não teria se obrigado. ${ }^{149}$

Em 1774, o Direito da Terra prussiano também incorporou a referida cláusula, no Título $1^{\circ}$, Capítulo $5^{\circ}, \S \S 377$ e 378 :

Exceto o caso de efetiva impossibilidade, o cumprimento de um contrato, em regra, não pode ser recusado por mudança de circunstâncias.

Contudo, se por imprevisível mudança se tornou impossível atingir o escopo final de ambas as partes, expressamente declarado ou resultante da natureza do ato, pode qualquer delas desistir desde que esse ato não tenha sido

\footnotetext{
${ }^{145}$ OSTI, Giuseppe. Scritti Giuridici. Milano: Giuffrè, 1973. p. 201.

146 RODRIGUES JÚNIOR, Otavio Luiz. Revisão judicial dos contratos. Autonomia da vontade e teoria da imprevisão. São Paulo: Atlas, 2006. p. 40.

${ }^{147}$ OSTI, Giuseppe. Op. cit., p. 200.

148 SCHUNCK, Giuliana Bonanno. A onerosidade excessiva superveniente no Código Civil: críticas e questões controvertidas. São Paulo: LTR, 2010. p. 41.

${ }^{149}$ OSTI, Giuseppe. Op. cit., p. 211.
} 
executado.

No Código Civil austríaco, a cláusula teve acolhida em uma particular aplicação, mais precisamente no $\$ 936$, que tratava do contrato preliminar e que colocava entre as condições de sua validade que, após a sua celebração, não se modificassem as circunstâncias, que se frustrasse o fim expressamente determinado ou resultante das circunstâncias, ou que fosse diminuída a confiança de uma ou outra parte. ${ }^{150}$

Com a Revolução Francesa, os franceses sentiram a necessidade de elaborar uma codificação, com a pretensão de que tudo que fosse juridicamente relevante estivesse ali disciplinado, para que o direito fosse igual para todos, sem distinção de classe ou região da França. Surge, então, o Código Civil, também conhecido como “Código Napoleônico", o qual, como já dito, entrou em vigor em 1804 e que tornou expressa a obrigatoriedade dos contratos, através do disposto em seu artigo $1.134^{151}$, não fazendo qualquer menção à cláusula rebus sic stantibus.

Esse Código era reflexo de um Estado Liberal, que pouco intervinha nas relações privadas, e as justificativas para a redação do referido artigo 1.134 foram:

A) Intangibilidade das Convenções:

1. Princípio. Em nenhum caso é possível aos tribunais modificar o que ficou acordado entre as partes.

2. O juiz não pode, nas relações contratuais, tomar o lugar de uma das partes para exercer em seu nome uma opção que a ela é reservada, nem autorizar o co-contratante que não tinha direitos antes da convenção a agir no lugar da parte prejudicada.

3. Quando uma cláusula penal está prevista, em caso de denúncia unilateral do contrato, o juiz não pode aplicá-la nas resilições judiciais.

4. Poderes do juiz: conversão da obrigação do contrato em complemento de renda vitalícia; intervenção para o prosseguimento do contrato inicial; suspensão da execução de uma obrigação.

E) Revogação das Convenções

14. Se, nos termos do art. 1.134, as convenções legalmente formadas não podem ser revogadas senão pelo acordo dos contraentes, tal acordo, que não deve ser submetido a qualquer condição formal, pode ser tácito e resultar das circunstâncias, cuja apreciação será do juiz do caso.

15. Resulta do art. 1.134 que nos contratos de execução sucessiva a resilição unilateral é comum às duas partes. ${ }^{152}$

\footnotetext{
${ }^{150}$ SCHUNCK, Giuliana Bonanno. A onerosidade excessiva superveniente no Código Civil: críticas e questões controvertidas. São Paulo: LTR, 2010. p. 41.

${ }^{151}$ No original, em francês: "Les conventions légalement formées tiennent lieu de loi à ceux que les ont faites. Elles ne peuvent être révoquées que de leur consentement mutuel, ou pour les causes que la loi autorise. Elles doivent être executées de bonne foi".

${ }^{152}$ BORGES, Nelson. A teoria da imprevisão no Direito Civil e no Processo Civil. São Paulo: Malheiros, 2002. p. 493-494.
} 
Nas palavras de Anísio José de Oliveira, "Era o retôrno à velha doutrina romana do intagibilidade do contrato. Era o advento do individualismo do século XIX. E a cláusula "rebus sic stantibus" tornou-se peça de museu, foi condenada ao abandono". ${ }^{153}$ No mesmo sentido, J. M. Othon Sidou coloca:

Os ideais da Revolução francesa, estes sim, impregnados do mais férreo individualismo, e a própria evolução econômica, na marca instituidora do capitalismo, inspiraram o direito das várias nações, notadamente de origem romanista (daí da classificação de Niboyet chamando-as "grupo latino") a restaurar na plenitude o pacta sunt servanda. ${ }^{154}$

Na França, não obstante o disposto no referido artigo 1.134 do Código Civil, as decisões proferidas pelos Tribunais acabaram por romper a estrutura não revisionista, diante da nova realidade econômica e social.

Antes mesmo da I Guerra Mundial, em 1843, uma dessas decisões foi proferida pelo Tribunal de Comércio de Rouen. No caso, determinada firma de Paris e outra de Rouen celebraram um contrato, por um período de dois anos, sobre a comum exploração de uma estrada que ligava as duas cidades e cujo percurso demandava uma média de três dias de viagem. Contrariando o que se poderia esperar, foi inaugurada, no ano seguinte, uma ferrovia entre Paris e Rouen, que somente exigia meio dia no trajeto. A firma parisiense pediu a resolução do contrato, carente de finalidade. Os tribunais admitiram que a inauguração da ferrovia representava um caso de força maior, em razão do qual resultava impossível o cumprimento do contrato. Na realidade, o cumprimento era perfeitamente possível, mas economicamente não teria finalidade. Decidiu o Tribunal:

A convenção celebrada entre os comissários de transporte pode ser considerada extinta por força maior, em consequência da circulação do trem, mesmo que no instante da conclusão do contrato a linha de ferro esteja em construção, se resultar, sem qualquer dúvida, que não era intenção das partes contratantes continuar a exploração e fazer concorrência às estradas de ferro. ${ }^{155}$

Outra decisão refere-se ao caso do Canal Craponne, datado de 1876, cuja construção se destinava a irrigar terras agricultáveis, mediante certo pagamento. Sobre o caso, relata

\footnotetext{
153 OLIVEIRA, Anísio José. A Cláusula "Rebus Sic Stantibus"' através dos tempos. Belo Horizonte: [s.n.], 1968. p. 45.

${ }^{154}$ SIDOU, J. M. Othon. A cláusula "Rebus sic stantibus" no Direito Brasileiro. Rio de Janeiro: Freitas Bastos, 1962. p. 24.

${ }^{155}$ BORGES, Nelson. A teoria da imprevisão no Direito Civil e no Processo Civil. São Paulo: Malheiros, 2002. p. 113 .
} 
Borges que, após 300 anos de operação, a quantia devida em razão da irrigação tornou-se defasada e irrisória, levando-se ao Tribunal de Aix e, mais tarde, à Corte de Apelação uma revisão contratual em razão de modificação da base negocial. A ação foi acolhida e posteriormente a decisão foi anulada pela Corte de Cassação. ${ }^{156}$

Em outra decisão, a primeira efetuada por um colegiado superior, provocado pela I Guerra Mundial, desta vez proferida pelo Tribunal do Comércio de Toulouse, um alfaiate estava empregado na casa de dois costureiros de luxo, mediante pagamento de 350 francos mensais. Entretanto, em razão da situação anormal e imprevisível produzida pela guerra, ocorreu redução e mesmo desaparecimento de grande parte de sua clientela, de modo que os costureiros não podiam mais proporcionar ao alfaiate o trabalho habitual, propondo suspender os preços a ele prometidos. $\mathrm{O}$ alfaiate rejeitou a proposta e exigiu o pagamento do trabalho contratado, entre $1^{\circ}$ de setembro de 1914 e 20 de junho de 1915, sustentando que um acontecimento como a guerra não poderia se transformar em caso de força maior, liberando os débitos contratados ou suspendendo-lhes a execução, mesmo que representasse obrigações mais difíceis ou onerosas a cumprir. Diante da comprovada alteração das circunstâncias, seus argumentos foram rejeitados. ${ }^{157}$

Decisão muito conhecida refere-se ao caso Compagnie Générale d'Eclariage de Bordeaux x Ville de Bordeaux, no ano de 1916. Em 8 de março de 1904, a referida companhia celebrou, com o Município de Bordeaux, um contrato de concessão, por 30 anos, para a distribuição de gás e energia elétrica em toda a região. Em contraprestação, ficou estabelecida uma tarifa móvel, condicionada às variações do preço de aquisição do carvão, mas circunscrita a rígidos limites. Em 1915, já durante a I Guerra ${ }^{158}$, a companhia pediu à Municipalidade a modificação das tarifas fixadas, pois, em virtude da guerra, vários fatores levaram à elevação daquela matéria-prima: i) elevação dos preços dos transportes marítimos; ii) redução dos centros produtores (invasão da Bélgica e Norte da França); iii) aumento do consumo pelas indústrias de guerra, que, por lei, tinham prioridade na utilização do produto; iv) escassez de mão de obra especializada; v) a queda de consumo; vi) aumento dos preços do carvão em 100\% em relação a 1913.

Diante dessa nova realidade, a companhia pediu à municipalidade autorização para elevar o preço das tarifas, o que foi negado pelo Conselho da Prefeitura de Bordeaux, invocando, entre outros argumentos, o artigo 1.134 do Código Civil Francês, ou seja, a pacta

\footnotetext{
${ }^{156}$ BORGES, Nelson. A teoria da imprevisão no Direito Civil e no Processo Civil. São Paulo: Malheiros, 2002. p. 113-114.

${ }^{157}$ Loc. cit.

${ }^{158}$ Que teve início em 28 de julho de 1914. (N. da A.).
} 


\section{sunt servanda.}

Um recurso contra esta decisão foi dirigido à instância superior, representada pelo Conselho da Prefeitura da Gironda, mas houve a confirmação da decisão recorrida, interpondo, destarte, a companhia apelação para o Conselho de Estado, o qual reformou os dois julgados anteriores, determinando a revisão do pacto e a condenação à reparação da indenização pleiteada. Pela primeira vez na França houve, neste julgado, a adoção da noção de imprevisão como causa determinante para revisão ou extinção dos pactos. ${ }^{159}$

Relativamente ao caso da Compagnie Général d'Eclariage, ressaltou Ripert:

Foi sobretudo durante a guerra que esta jurisprudência sobre a imprevisão se afirmou. Na célebre decisão de 30 de março de 1916, dada a favor da Companhia do Gás de Bordeus, o Conselho de Estado, depois de ter posto o princípio de que "o contrato de concessão regula duma maneira definitiva até a sua expiração as obrigações respectivas do concessionário e do concedente", declara que "a economia do contrato se encontra perturbada" quando a alta do carvão é tal "que excede certamente os limites extremos dos aumentos susceptíveis de serem encarados pelas partes no ato do contrato", e reenvia as partes ao Conselho de Prefeitura para uma revisão dos preços. ${ }^{160}$

Por fim, outra demonstração de mitigação da causa não-revisionista está na chamada Lei Failliot, também conhecida como "Lei da Guerra", datada de 21 de maio de 1918, em que se verifica a aplicação da velha cláusula rebus sic stantibus, sob esta nova roupagem teórica, como dito, a teoria da imprevisão.

A mencionada Lei Failliot dispunha:

Art. $1^{\circ}$. No período de duração da guerra até a expiração de um prazo de três meses, a partir da cessação das hostilidades, as disposições excepcionais seguintes serão aplicadas aos contratos e a todos os compromissos e obrigações que tenham caráter mercantil para as partes ou unicamente para uma delas, para todos os contratos concluídos antes de $1^{\circ}$ de agosto de 1914 , e que determinavam seja a entrega de mercadorias ou de bens, ou de serviços, seja de quaisquer prestações sucessivas ou unicamente diferenciadas.

Art. $2^{\circ}$. Independentemente das causas de resolução resultante de direito comum ou das convenções, as mercadorias ou obrigações que estejam compreendidas no artigo precedente podem ser rescindidas pela ação de qualquer das partes, seja porque se estabeleceu uma razão de estado de guerra, seja porque a execução da obrigação por um dos contratantes está tão onerada que lhe causará um prejuízo cuja importância ultrapassará, em muito, as previsões que poderiam ser razoavelmente feitas à época do contrato.

\footnotetext{
${ }^{159}$ BORGES, Nelson. A teoria da imprevisão no Direito Civil e no Processo Civil. São Paulo: Malheiros, 2002. p. 118.

${ }^{160}$ RIPERT, Georges. A regra moral nas obrigações civis. Campinas: Bookseller, 2000. p. 149.
} 
Ainda antes da Lei Failliot, alguns doutrinadores como Pothier já aderiam à teoria revisionista, baseando seu posicionamento no disposto no artigo $1.150^{161}$ do code francês, que dispunha não estar o devedor obrigado além dos seus deveres e interesses previstos ou previsíveis por ocasião do contrato quando não resultantes de seu dolo, e a obrigação não fosse cumprida. Também os adeptos da revisão invocavam o artigo $1.156^{162}$, o qual dispunha sobre o atendimento à comum intenção das partes, à semelhança do artigo 85 do Código Civil brasileiro de $1916 .^{163}$

$\mathrm{Na}$ Itália, o referido Código Civil de 1865, influenciado pelo pensamento napoleônico, fixou-se à pacta sunt servanda, quando no artigo 1.123 ficou expresso que "os contratos tinham força de lei para aqueles que os celebrassem, só podendo ser revogados por mútuo acordo ou por razões legais". Nas palavras de Nelson Borges, "Foram recepcionadas, mutatis mutandis, as mesmas disposições do artigo 1.134 do Código Civil francês".

Em 1915 surgiu na Itália o Decreto 739 o qual dispunha que o chefe de família que fosse ou tivesse sido combatente poderia pedir a resolução do contrato de locação, considerando a guerra como situação de força maior. Posteriormente, em 1918, o Decreto 880 reconheceu a possibilidade de aplicação da imprevisão aos contratos de arrendamento agrícola. Ressalta-se, entretanto, que após a Guerra, “curiosamente a jurisprudência italiana acabou por repudiar totalmente a cláusula romana". 164

Por outro lado, com a entrada em vigor do Código Civil de 1942, ao mesmo tempo em que se reconheceu a obrigatoriedade dos contratos (artigo 1.372), foi contemplada a teoria da imprevisão (artigo 1.467): ${ }^{165}$

Art. 1.372. O contrato tem força de lei entre as partes. Não pode ser desfeito senão por mútuo consenso ou por causa prevista em lei. ${ }^{166}$

Art. 1.467. Nos contratos de execução continuada, periódica ou de execução futura, se a prestação de uma das partes tornou-se excessivamente onerosa em consequência de acontecimentos extraordinários e imprevisíveis, a parte

\footnotetext{
${ }^{161} \mathrm{Na}$ língua original: “Art. 1.150. Le débitur n'est tenu que des dommages et intérêts qui ont été prévus ou qu'on a pu prévoir lors du contrat, lorsque ce n'est point par son dol que l'obligation n'est point exécutée."

${ }^{162} \mathrm{Na}$ língua original : “Art. 1.156. On doit dan les conventions rechercher quele a été la commune intention des parties contractantes, plutôt que de s'arrêter au sens littéral des termes."

${ }^{163}$ BORGES, Nelson. A teoria da imprevisão no Direito Civil e no Processo Civil. São Paulo: Malheiros, 2002. p. 490.

${ }^{164}$ Ibid., p. 457.

${ }^{165}$ Sobre a compatibilidade entre a cláusula rebus sic stantibus e a pacta sunt servanda, são os ensinamentos de Nelson Borges: "Reitere-se: os princípios pacta sunt servanda e rebus sic stantibus são harmônicos e complementares, não colidentes ou excludentes um do outro. Representam a mais perfeita justiça comutativa" (Ibid., p. 458).

166 Do original, em italiano: "Il contrato ha forza di legge tra le parti. Non può essere sciolto che per mutuo consenso o per cause ammesse dalla legge.”
} 
que deve tal prestação pode demandar a resolução do contrato, com os efeitos estabelecidos no art. 1.458.

A resolução não pode ser demandada se a onerosidade superveniente entrar na álea normal do contrato.

A parte contra a qual é demandada a resolução pode evitá-la oferecendo modificar igualmente as condições do contrato. ${ }^{167}$

O Código Civil alemão de 1900 não fez menção à cláusula rebus sic stantibus, não obstante a proposta de Windscheid de inserção de sua teoria da pressuposição, sobre a qual se discorrerá oportunamente. Não obstante isto, a cláusula "rebus sic stantibus" foi invocada em sua plenitude "desde o início da Primeira Grande Guerra devido às dificuldades encontradas, relativas à escassez de matérias primas e à enorme depreciação do marco". ${ }^{168}$

Relativamente ao Direito alemão, Bezerra Cavalcanti, forte no pensamento de Enneccerus ${ }^{169}$, ensina que o direito de resolução por imprevisão encontraria justificativa no princípio da boa-fé, contemplado no $§ 242^{170}$ do Código Civil alemão.

Com o advento da I Guerra Mundial (1914) ${ }^{171} 172173$, a cláusula rebus foi despertada

${ }^{167}$ Do mesmo modo: "Nei contratti a esecuzione continuata o periodica ovvero a esecuzioone differita, se la prestazione di uma delle parti è divenuta eccessivamente onerosa per il verificarsi di avvenimenti straordinari e imprevedibili, la parte che deve tale prestazione può domandare la risoluzione del contratto, com gli effetti stabiliti dall'art. 1.458. La risoluzione non può essere domandata se la sopravvenuta onerosità rientra nell'alea normale del contratto. La parte contro la quale è domandata la risoluzione può evitarla offrendo de modificare equamente le condizioni del contratto."

168 OLIVEIRA, Anísio José. A Cláusula 'Rebus Sic Stantibus'” através dos tempos. Belo Horizonte: [s.n.], 1968. p. 62.

${ }^{169}$ BEZERRA CAVALCANTI, Francisco de Queiroz. A teoria da imprevisão. Revista Forense, Rio de Janeiro, n. 260, p. 110, 1977.

${ }^{170}$ Em tradução livre da autora: "O devedor está obrigado a efetuar a prestação como o exige o princípio da boafé tendo em conta os usos e costumes".

171 "Mas vieram as hostilidades, surgindo a $1^{\text {a }}$ Grande Guerra. Entendeu-se que os dispositivos vigentes até então de maneira alguma comportavam a dolorosa e extraordinária revolução econômico-jurídica em todo o globo, já que a hecatombe de 1914-1918, pela sua amplitude, vastidão e acima de tudo pelas inferências, foi uma eventualidade jamais igualada [...] O resgate dos contratos a esse tempo tornou-se, na sua grande maioria, um soturno séquito com destino irremediável ao desmoronamento patrimonial; e para outros, em flagrante minoria, uma oblação iníqua e injusta mesmo". (OLIVEIRA, Anísio José. A teoria da imprevisão nos contratos. Belo Horizonte: [s.n.], 1968. p. 45).

${ }^{172}$ Embora Othon Sidou afirme que "Embora a vinculação contratual fique agravada quando dos conflitos armados - preleciona o mestre Carneiro Maia - sentindo-se nesta contingências a presença mais amiúde da cláusula rebus sic stantibus, não descende ela, em linha reta, de tais situações. Não é, pois, em teoria, ligada necessariamente à idéia de guerra. E rematando o raciocínio, escreve o civilista paulistano: a subversão das bases econômicas do contrato, que não pode ficar indiferente aos anseios da justiça comutativa, ocorre quando atuam fatores extraordinários. E estes fatores não são privativos das condições gerais de instabilidade que a guerra acarreta". (SIDOU, J. M. Othon. A cláusula "Rebus sic stantibus" no Direito Brasileiro. Rio de Janeiro: Freitas Bastos, 1962. p. 28).

173 Também Paulo Carneiro Maia assinala que "Embora a vinculação contratual fique agravada quando dos conflitos armados, sentindo-se, nestas contingências, a presença mais amiúde da cláusula rebus sic stantibus, não descende ela, em linha reta, de tais situações. Sabemos que esta noção, nos seus variados estágios, como ensina BONNECASE, " $n$ 'est, en théorie, nullement liée de guerre”. Manifesta-se em todas as épocas, na paz como na guerra, desde que concorram acontecimentos extraordinários e imprevisíveis. A subversão das bases econômicas do contrato, que não pode ficar indiferente aos anseios da justiça comutativa, ocorre quando atuam fatôres extraordinários. E estes fatôres não são privativos das condições gerais de instabilidade que a guerra acarreta. Também nos períodos de concórdia dos povos, o surgimento de fatos imprevisíveis e invencíveis 
"como fiel da balança da justiça comutativa", ${ }^{174}$ mas com nova roupagem, isto é, sob a roupagem da teoria da imprevisão. Os tribunais alemães encontraram fundamento para a aplicação da cláusula no $§ 242$ do Código Civil alemão, que impõe aos contratantes da obrigação de agir de acordo com a boa-fé. ${ }^{175}$ No ano de 2002, o referido Código sofreu uma reforma, e o seu $\S 313^{176}$ passou a contemplar expressamente a alteração das circunstâncias prevendo:

$\S 313$ Interferência na base do contrato

(1) Se as circunstâncias com base nas quais as partes firmaram contrato se alterarem de forma substancial após a contratação, de forma que, se as partes tivessem previsto tal alteração, não teriam firmado o contrato, ou o teriam feito em termos diferentes, poderá ser pleiteada a adaptação do contrato, na medida em que, considerando todas as circunstâncias do caso concreto, particularmente a alocação contratual ou legal dos riscos, não se possa razoavelmente esperar que a parte continue obrigada ao contrato, nos termos originalmente pactuados.

(2) Se pressupostos relevantes integrantes da base do contrato se revelarem posteriormente incorretos, deverão ser tratados como se fosse alteração nas circunstâncias. ${ }^{177}$

(3) Se a adaptação do contrato não for possível, ou se não for razoável impôla a uma das partes, a parte prejudicada poderá rescindir o contrato. Em se tratando de contrato com prestações sucessivas, o direito de rescindir é substituído pelo direito de promover a resolução.

pode tornar impossível o cumprimento de cláusulas contratuais. A guerra, que quase sempre gera desequilíbrio econômico e conturbação política, produzindo instabilidade geral, por isto mesmo constitui conjuntura para a teoria florescer. Haja vista como, na primeira conflagração mundial, ela assumiu aspecto particularmente intenso e despertou novo interesse em sua aplicação. A questão, entretanto, desborda das circunstâncias estritamente ocasionais da guerra, que é estado anormal, e se põe de fato em tempos de paz. Não que a guerra seja sua causa geradora e exclusiva, embora, na sua ocorrência, sejam mais freqüentes e explicáveis os colapsos que atingem os fundamentos econômico-jurídicos dos contratos". (MAIA, Paulo Carneiro. Da cláusula rebus sic stantibus. São Paulo: Saraiva, 1959. p. 17-18).

${ }^{174}$ BORGES, Nelson. A teoria da imprevisão no Direito Civil e no Processo Civil. São Paulo: Malheiros, 2002. 109.

175 RODRIGUES JÚNIOR, Otavio Luiz. Revisão judicial dos contratos. Autonomia da vontade e teoria da imprevisão. São Paulo: Atlas, 2006. p. 46.

${ }^{176}$ Seção 313. Interferência na base do negócio.

(1) Se as circunstâncias que se tornaram a base de um contrato se modificarem significativamente desde a celebração e se as partes não tivessem celebrado o contrato ou o tivessem celebrado com conteúdo diferente se tivessem previsto esta mudança, a adaptação do contrato pode ser demandada, levando em consideração todas as circunstâncias do caso específico, em particular a contratual ou estatutária distribuição de riscos, uma das partes não pode razoavelmente esperar manter o contrato sem alteração.

(2) É equivalente a uma alteração de circunstâncias se concepções materiais que se tornaram base de um contrato forem consideradas incorretas.

(3) Se a adaptação do contrato não é possível ou se uma parte não pode razoavelmente aceitá-la, a parte prejudicada pode revogar o contrato. No caso de obrigações continuadas, o direito de rescindir toma o lugar do direito de revogar. (Tradução livre).

${ }^{177}$ Hannes Rösler traz o exemplo da venda de um quadro de Leibl em que à época da celebração, ambas as partes acreditavam que fosse obra de outro pintor. Logo após a celebração, o quadro foi atribuído a Leibl, aumentando significativamente o seu valor. (RÖSLER, Hannes. Hardship in German Codified Private Law. In: Comparative Perspective to English, French and International Contract Law. European Review of Private Law, v. 15 , n. 4, p. 484, 2007). 
$\mathrm{Na}$ Inglaterra, no início do século XX, ficaram famosos os casos conhecidos como coronation cases, os quais retratavam a situação de locação de janelas e varandas para assistir à passagem do cortejo real, ao tempo da coroação de Eduardo VII. Entretanto, em decorrência de súbita doença do Rei, a coroação foi adiada e as comemorações canceladas. Várias demandas surgiram, pois os locadores pretendiam receber ainda os alugueres sob o argumento de que, muito embora a cerimônia não tivesse ocorrido, os locatários não estavam impedidos de utilizar o espaço locado. Os locatários, por seu turno, sustentaram a tese da inutilidade das varandas, diante da frustração do fim do contrato, “[...] porquanto o vínculo tinha por causa a possibilidade de assistir o cortejo real", 178179

Os Tribunais desobrigaram os locatários do pagamento das rendas, sob o argumento de que era implícito que o fim do contrato restara frustrado com a doença do futuro rei, um fato superveniente e alheio à vontade das partes. Além disto, entendeu-se que a locação ocorreu com o propósito de presenciar o cortejo real e que não se deve ter em conta simplesmente os termos do contrato, mas também as circunstâncias que rodeiam ambas as partes contratantes. ${ }^{180}$

Também em razão da I Guerra, surgiram na Inglaterra leis de exceção que permitiam até mesmo a suspensão, a revisão ou a anulação de determinados contratos locatícios.

Em 1943, firmou-se a possibilidade de adequação de contratos em situações extraordinárias. Antes disto, porém, baseada em antiga regra da Common Law (em vigor até 1850), o posicionamento dos Tribunais ingleses era contrário à revisão dos contratos, adotando a regra where the tree falls, there let it lie, ou seja, "onde a árvore cair, deixa-a ficar".

Na Inglaterra, é famoso o caso Taylor versus Caldwell, datado de 1863, em que o primeiro havia locado um espaço musical (The Surrey Gardens and Music Hall) do segundo por quatro noites $(17 / 06,15 / 7,5 / 8$ e 19/8 de 1861) a $£ 100$ por noite, quando faria apresentações de canto lírico. Firmado o contrato, dois dias antes do início das apresentações, um incêndio acidental sinistrou o teatro. Taylor, então, impossibilitado de manter o espetáculo, processou Caldwell por perdas e danos (£58 com a preparação dos concertos) ante o cancelamento dos shows causado pela impossibilidade de uso do local.

\footnotetext{
${ }^{178}$ RODRIGUES JÚNIOR, Otavio Luiz. Revisão judicial dos contratos. Autonomia da vontade e teoria da imprevisão. São Paulo: Atlas, 2006. p. 62.

${ }^{179}$ Iturraspe e Piedecasas, forte na lição de Diez-Picazo, ensinam que a frustração corresponde à perda de sentido e de razão de ser da prestação e que isto aconteceria quando ela deixa de ser útil, isto é, quando não pode satisfazer o interesse do credor, seja porque é impossível alcançar o fim pretendido, seja porque o fim foi alcançado por outros meios. (ITURRASPE, Jorge Mosset; PIEDECASAS, Miguel A. La revisión del contrato. Santa Fe: Rubinzal Culzoni, 2008. p. 316).

${ }^{180}$ Ibid., p. 332.
} 
O Juiz Blackburn, por sua vez, rejeitou a pretensão de Taylor, deduzindo que, nos contratos em que a execução dependesse de existência de determinada pessoa ou coisa, seria considerada uma condição implícita, em que seria escusável a impossibilidade de execução decorrente de perecimento da pessoa ou da coisa, ou seja, não há uma estipulação expressa de que a destruição da pessoa ou da coisa deve escusar o cumprimento. A escusa estaria implícita na lei, pois a partir da natureza do contrato seria evidente que as partes contrataram tendo por base a existência dessa pessoa ou bem em particular. No caso em julgamento, ele verificou que as partes contrataram com base na existência continuada do Music Hall, no momento em que os concertos ocorreriam, e que isto seria essencial para o seu cumprimento.

Nesse sentido, entendeu que, deixando de existir o Music Hall, sem culpa de qualquer das partes, ambas estejam escusadas, ou seja, escusados os demandantes de tomar os jardins e pagar o dinheiro ( $£ 100$ por noite), os acusados de executar a promessa de ceder o uso do Hall, do jardim e de outras coisas. ${ }^{181} 182$

Nos Estados Unidos, o chamado Restatement of the Law, elaborado pela Association of American Law, contém uma consolidação de princípios, leis e precedentes de direito privado. Nos parágrafos 454 e 455 , há a abordagem dos temas impossibility e supervening impossibility:

$\S$ 454. Definição de impossibilidade. [...] impossibilidade significa não somente impossibilidade estrita, mas impraticabilidade em virtude de extrema dificuldade não razoável, gastos, danos ou perdas envolvidas. $\S 455$. Impossibilidade superveniente. [...] depois da formação do contrato, fatos que o promitente não tinha razão para prever e para a ocorrência do qual ele não tenha contribuído, tornem o desempenho da promessa impossível, a obrigação do promitente está extinta, a menos que a intenção contrária tenha sido manifestada, apesar de já ter ocorrido o inadimplemento

\footnotetext{
181 "[...] in contracts in which the performance depends on the continued existence of a given person or thing, a condition is implied that the impossibility of performance arising from the perishing of the person or thing shall excuse the performance. In none of these cases is the promise in words other than positive, nor is there any express stipulation that the destruction of the person or thing shall excuse the performance; but that excuse is by law implied, because from the nature of the contract it is apparent that the parties contracted on the basis of the continued existence of the particular person or chattel. In the present case, looking at the whole contract, we find that the parties contracted on the basis of the continued existence of the Music Hall at the time when concerts were to be given; that being essential to their performance. We think, therefore, that the Music Hall having ceased do exist, without fault of either party, both parties are excused, the plaintiffs from taking the gardens and paying the Money, the defendants from performing their promise to give the use of the Hall and Gardens and other things". (RÖSLER, Hannes. Hardship in German Codified Private Law. In: Comparative Perspective to English, French and International Contract Law. European Review of Private Law, v. 15 , n. 4, p. 484, 2007).

182 Neutral Citation Number: [1863] EWHC QB J1. 122 ER 309; 3B. \& S. 826. Disponível em: <http://bailii.org/ew/cases/EWCH/QB/1863/J1.html>. Acesso em: 15 out. 2009.
} 
por recusa anterior. ${ }^{183}$

Neste país, em razão de uma vertente econômica na interpretação e execução das relações contratuais, sob o impulso das teorias de Law and Economics, desenvolvidas pelos professores das Universidades de Chicago, o desequilíbrio negocial e a alteração das circunstâncias são institutos de caráter nitidamente excepcional. ${ }^{184}$

No Direito português, o Código Civil de 1867, conhecido como código de Seabra, também privilegiava a obrigatoriedade dos contratos, através do disposto no artigo 702, o qual previa: "Os contratos, legalmente celebrados, devem ser prontamente cumpridos; nem podem ser revogados ou alterados, senão por mútuo consentimento dos contratantes, salvas as exceções especificadas em lei”.

Entretanto, com a I Guerra, foram editados decretos (n. 1:536 de 27 de abril de 1915, 4:076 de 10 de abril de 1918 e 5:335 de 26 de março de 1919, entre outros) com o objetivo de estabelecer as condições em que os contratos firmados entre o Estado, ou os municípios e seus fornecedores e empreiteiros de obras públicas poderiam ser revistos.

Em 1966, com a aprovação do Decreto-Lei n. 47.344, entrou em vigor o atual Código Civil português, o qual destinou três artigos à resolução ou modificação do contrato por alteração das circunstâncias ${ }^{185}$ :

183 " $\$$ 454. Definition of impossibility. In the Restatement of this subject impossibility means not only strict impossibility but impracticability because of extreme and unreasonable difficulty, expense, injury or loss involved.

$\$$ 455. Supervening impossibility. Excepted as states in where, after the formation of a contract, facts that a promisor had no reason to anticipate, and for the occurrence of which he is not contributing fault, render performance of the promise impossible, the duty of the promisor is discharged, unless a contrary intention has been manifested, even though he has already committed a breach by anticipatory repudiation." (Disponível em

http://www.heinonline.org/HOL/LandingPage?collection=journal\&handle=hein.journals/walq $18 \& d i v=23 i d=\&$ page $=>$. Acesso em 14.01.2013).

${ }^{184}$ RODRIGUES JÚNIOR, Otavio Luiz. Revisão judicial dos contratos. Autonomia da vontade e teoria da imprevisão. São Paulo: Atlas, 2006. p. 64.

${ }^{185}$ Neste sentido, analise-se acórdão do Supremo Tribunal de Justiça português: "I - O artigo 437 do Código Civil consagra o princípio da imprevisão com base na alteração anormal das circunstâncias em que as partes tenham fundado a decisão de contratar. II - Igual princípio se encontra consagrado, no domínio do contrato de empreitada, contrato que se prolonga no tempo, quer em relação as obras públicas (Decreto-Lei n. 237-B/75), quer em relação a obras particulares (Decreto-Lei n. 474/77, de 12 de Novembro), devendo, porém, neste caso, constar do contrato as condições em que se verificara a revisão de preços (artigo 2 n. 2 do Decreto-Lei n. 474/77). III - Decidido pelas instâncias que as partes acordaram que as quantias respeitantes a todos os pagamentos a efectuar pelos réus ficariam sujeitos a revisão de preços de acordo com os índices estabelecidos para o Estado - empreitadas de obras públicas, daqui não que seja aplicável ao contrato o Decreto-Lei n. 273B/75, mas apenas que e aplicável o Decreto-Lei n. 474/77 com a consideração de que a revisão terá em conta os índices estabelecidos para o Estado (n. 1 do artigo 2 desta douta-Lei). IV - Tendo os trabalhos sido executados e os fornecimentos feitos para além do prazo fixado para o cumprimento da obrigação não há lugar a revisão de preços (artigo 4 n. 6 do Decreto-Lei n. 474/77).

$\mathrm{V}$ - Se o incumprimento foi devido a realização de trabalhos a mais determinados pelo dono da obra, cabia ao devedor provar tal facto, o que não fez". (Processo n. 078767, Rel. Cura Mariano, j. em 03.05.1990. Votação por unanimidade). 
Art. $437^{\circ}$

Condições de admissibilidade

1. Se as circunstâncias em que as partes fundaram a decisão de contratar tiverem sofrido uma alteração anormal, tem a parte lesada direito à resolução do contrato, ou à modificação dele segundo juízos de equidade, desde que a exigência das obrigações por ela assumidas afecte gravemente os princípios da boa fé e não esteja coberta pelos riscos próprios do contrato.

2. Requerida a resolução, a parte contrária pode opor-se ao pedido, declarando aceitar a modificação do contrato nos termos do número anterior. Art. $438^{\circ}$

Mora da parte lesada

A parte lesada não goza do direito de resolução ou modificação do contrato, se estava em mora no momento em que a alteração das circunstâncias se verificou.

Art. $439^{\circ}$

Regime

Resolvido o contrato, são aplicáveis à resolução as disposições da subsecção anterior.

Verifica-se, portanto, que em Portugal a parte lesada tem direito à resolução do contrato ou à sua modificação segundo juízos de equidade.

A Argentina, por seu turno, passou a aceitar a revisão a partir de 1964, quando, através da Lei 17.711 de 1968 , foi alterado o seu Código Civil ${ }^{186}$, dando a seguinte redação ao $\S 2^{\circ}$ do artigo 1.198:

Os contratos devem celebrar-se, interpretar-se e executar-se de boa-fé e de acordo com o que, de forma verossímel as partes entenderam ou puderam entender, obrando com cuidado e previsão.

Nos contratos bilaterais comutativos e nos unilaterais onerosos e comutativos de execução diferida ou continuada, se a prestação a cargo de uma das partes se tornar excessivamente onerosa, por acontecimentos extraordinários e imprevisíveis, a parte prejudicada poderá demandar a resolução do contrato. O mesmo princípio se aplicará aos contratos aleatórios quando a excessiva onerosidade se produza por causas estranhas ao risco próprios do contrato.

Nos contratos de execução continuada a resolução não alcançará os efeitos já ocorridos.

Não procederá a resolução se o prejudicado tiver agido com culpa ou estivesse em mora.

A outra parte poderá impedir a resolução oferecendo melhorar equitativamente os efeitos do contrato. ${ }^{187}$

\footnotetext{
${ }^{186}$ BEZERRA CAVALCANTI, Francisco de Queiroz. A teoria da imprevisão. Revista Forense, Rio de Janeiro, n. 260, p. 113, 1977.

${ }^{187}$ No original: "Los contratos deben celebrarse, interpretarse y ejecutarse de buena fe y de acuerdo con lo que verosímilmente las partes entendieron o pudieron entender, obrando con cuidado y previsión.

En los contratos bilaterales conmutativos y en los unilaterales onerosos y conmutativos de ejecución diferida o continuada, si la prestación a cargo de una de las partes se tornara excesivamente onerosa, por acontecimientos extraordinarios e imprevisibles, la parte perjudicada podrá demandar la resolución del contrato. El mismo principio se aplicará a los contratos aleatorios cuando la excesiva onerosidad se produzca por causas extrañas al riesgo propio del contrato.
} 
Segundo Nelson Borges, Carlos Cossio foi o responsável pela aceitação da imprevisibilidade no ordenamento jurídico argentino, alicerçando o seu emprego em sua teoria egológica do Direito. ${ }^{188}$ Antes da referida alteração, o país era fortemente influenciado pelo code francês, adotando posição não revisionista.

No Uruguai, até a metade dos anos 40, a jurisprudência mostrava-se indiferente à teoria da imprevisão. Atualmente, o artigo $1.291^{189}$ do Código Civil deste país, com modificações realizadas em 1995, prevê:

Os contratos legalmente celebrados formam uma regra à qual devem submeter-se as partes como à própria lei.

Todos devem ser executados de boa-fé e por conseguinte, obrigam não somente ao que neles se expressa, mas também a todas as consequências que segundo sua natureza sejam conformes à equidade, ao uso ou à lei.

A Bélgica, por ter sido um Reino incorporado à França em 1795, tornando-se soberano apenas no século XIX, sofreu, consequentemente, grande influência da concepção francesa contrária à revisão. Também em razão da I Guerra, em 11 de outubro de 1919, com inspiração na já referida Lei Failliot, uma lei possibilitou a revisão judicial dos contratos, em especial dos contratos administrativos. Apenas em 1930 é que passou a permitir a rescisão dos contratos de locação a longo prazo, concluídos antes de 31 de dezembro de 1923, "quando as obrigações de um dos contratantes fossem desproporcionais aos benefícios auferidos com o

En los contratos de ejecución continuada la resolución no alcanzará a los efectos ya cumplidos.

No procederá la resolución, si el perjudicado hubiese obrado con culpa o estuviese en mora.

La otra parte podrá impedir la resolución ofreciendo mejorar equitativamente los efectos del contrato".

${ }^{188}$ Cossio "distinguiu três sentidos para os contratos: $1^{\circ}$ ) um acordo de vontades a criar, modificar e extinguir direitos; $2^{\circ}$ ) contrato como conduta que, no acordo de vontades, significaria um projeto de existência; $3^{\circ}$ ) contrato como instrumento, reduzido à forma escrita. No primeiro sentido, seria um significante - expressão que diz algo; e no segundo, um significado - objeto sobre o qual se diz algo, consoante exposto. Na solidária visão de Cossio o contrato começa e termina como conduta contrapartida, dentro de um projeto de existência, decidido conjuntamente pelas partes. Esta concepção de rara beleza ideológica (essência da teoria egológica do Direito), a justificar a aceitação da teoria da imprevisão, conseguir fundir de maneira sólida e admirável, em um só cadinho, forma e conteúdo. Mas toda a argumentação do grande jurista argentino, na busca da natureza jurídica da imprevisão, teve como alicerce três grandes suportes, a saber: a boa-fé, considerada como um ato consumado, uma vez que deve estar presente na consciência de cada um dos contratantes, porque sem ela é impossível a constituição válida de um acordo de vontades, indissoluvelmente ligada a uma verdadeira conduta contratual; a complementaridade e harmonia dos princípios "pacta sunt servanda" e "rebus sic stantibus", porquanto, na sua maneira de pensar, nenhum pode subsistir sem o outro, expressões que são da mesma boa-fé constitutiva da conduta contratual contrapartida; e, por último, o chamado entendimento societário assemelhado ao solidarismo, de Louveau -, definido como sendo a convivência assentada em uma verdade de conduta que outra garantia não tem além da visão de um mundo solidário e da conseqüente boa-fé dos contratantes" (BORGES, Nelson. A teoria da imprevisão no Direito Civil e no Processo Civil. São Paulo: Malheiros, 2002. p. 477-478).

${ }^{189}$ Da redação em língua originária: "Los contratos legalmente celebrados forman una regla a la cual deben someterse las partes como a la ley misma. Todos deben ejecutarse de buena fe y por consiguiente obligan, no sólo a lo que en ellos se expresa, sino a todas las consecuencias que según su naturaleza sean conformes a la equidad, al uso o a la ley". 
contrato, ou às prestações do outro contratante" ${ }^{\prime 190}$.

O Código Civil japonês de 1896 prevê, em seu artigo 415:

Se um devedor não cumpre a obrigação de conformidade com sua real intenção, o credor pode reclamar compensação por danos. O mesmo ocorre se o devedor torna-se incapaz de cumprir a obrigação por alguma causa a ele atribuída. ${ }^{191}$

Ou seja, de acordo com esse dispositivo, é possível inferir-se a manutenção do vínculo contratual nas hipóteses contidas no referido artigo. Entretanto, leis especiais admitem a revisão excepcionalmente, como, por exemplo, uma lei de 08.04.1921, que autorizou o pedido de aumento ou diminuição de renda, verificada a existência de circunstâncias excepcionais, na locação de terrenos ou prédios, e a de 21.04.1922, que admitiu, em face de alterações imprevisíveis, a forma de administração do bem dado em fidúcia. ${ }^{192}$

\subsection{A CLÁUSULA REBUS SIC STANTIBUS NO BRASIL}

No Anteprojeto do Código Civil proposto por Teixeira de Freitas, havia a aceitação da doutrina da imprevisibilidade, em razão da redação do artigo 454, a qual previa:

Haverá ignorância de fato, quando os agentes não tiverem absolutamente sabido do que existia, ou não existia, ou do que podia acontecer, em relação ao fato que foi causa principal da determinação da vontade. Haverá erro de fato, quando supuseram verdadeiro o que era falso, ou falso o que era verdadeiro, também em relação ao fato que foi causa principal da determinação da vontade.

O Código Civil brasileiro de 1916, por sua vez, tinha uma carga ideológica similar à do Código Civil napoleônico. Desta forma, prevalecia também a concepção de que o "contrato faz lei entre as partes", muito embora o referido codex não fizesse expressa menção a isto.

De acordo com Nelson Borges, o mais antigo registro legislativo a colocar em xeque a intangibilidade dos pactos foi a Lei 4.403, de 1921, sobre locação de prédios urbanos.

\footnotetext{
${ }^{190}$ MAIA, Paulo Carneiro. Da cláusula rebus sic stantibus. São Paulo: Saraiva, 1959. p. 125.

${ }^{191}$ DONNINI, Rogério Ferraz. A revisão dos contratos no Código Civil e no Código de Defesa do Consumidor. 2.ed. São Paulo: Saraiva, 2001. p. 61.

192 BORGES, Nelson. A teoria da imprevisão no Direito Civil e no Processo Civil. São Paulo: Malheiros, 2002. p. 498.
} 
Posteriormente, com a Revolução de 1930, várias leis esparsas consagraram a teoria da imprevisão, como, por exemplo, o Decreto 19.573/1931, Decreto 20.626/1931, Decreto 23.501/1933, Decreto 24.150/1934, Decreto-lei 6.739/1944, Decreto 869/1938, Lei $1.521 / 1951$ e Lei $6.899 / 1981 .^{193}$

A doutrina fundamentava a tese revisionista no artigo $4^{\circ}$ da Lei de Introdução às normas do Direito Brasileiro, o qual prevê, na hipótese de lacunas, a decisão de acordo com a analogia, os costumes e os princípios gerais do direito, bem como no artigo $5^{\circ}$ da mesma lei, o qual prevê que: "Na aplicação da lei, o juiz atenderá aos fins sociais a que ela se dirige e às exigências do bem comum".

Além destes artigos, fundamentavam a tese os artigos 126, 127 e 1.209 do Código de Processo Civil, e artigos 85, 401, 762, I e II, 879, 954, III, 1.059, parágrafo único, 1.060, $1.091,1.092,2^{\mathrm{a}}$ parte $1.131,1.181,1.190,1.214,1.246,1.250,1.256,1.499 .{ }^{194}$

Em 1941, Orosimbo Nonato, Philadelpho de Azevedo e Hahnemann Guimarães elaboraram um Anteprojeto de Código das Obrigações, o qual, no artigo 322, previa que:

Quando, por força de acontecimentos excepcionais e imprevistos ao tempo da conclusão do ato, opõe ao cumprimento exato desta dificuldade extrema, com prejuízo exorbitante para uma das partes, pode o juiz, a requerimento do interessado e considerando com equanimidade a situação dos contratantes, modificar o cumprimento da obrigação, prorrogando-lhe o termo ou reduzindo-lhe a importância.

Logo após, Francisco Campos deu uma redação mais ampla para a hipótese, abrindo a possibilidade tanto para a modificação como para a resolução contratual, nos seguintes termos:

Art. O juiz pode ordenar a resolução ou a revisão do contrato quando,
em razão de circunstâncias que não podiam ser previstas, o devedor, na
execução de prestações futuras, seja onerado por prejuízo considerável e o
credor aufira um proveito injusto.
Parágrafo único - Não se incluem entre os contratos a que se refere o art.
os contratos inspirados por fins de especulação, os contratos aleatórios
quando a álea se verifica, os negócios que devem liquidar-se por diferenças,
os negócios a termo nas bolsas de valores ou de mercadorias.

Em 1963, por sua vez, Caio Mário da Silva Pereira elaborou um novo Anteprojeto de Código de Obrigação, propondo a seguinte redação, no seu artigo 358:

\footnotetext{
${ }^{193}$ BORGES, Nelson. A teoria da imprevisão no Direito Civil e no Processo Civil. São Paulo: Malheiros, 2002. p. 510.

${ }^{194}$ Ibid., p. 513-514.
} 
Nos contratos de execução diferida ou sucessiva, quando, por força de acontecimento excepcional e imprevisto ao tempo de sua celebração, a prestação de um das partes venha a se tornar excessivamente onerosa, capaz de gerar para ela grande prejuízo e para a outra parte lucro exagerado, pode o juiz, a requerimento do interessado, declarar a resolução do contrato.

A sentença, então proferida, retroagirá seus efeitos à data da citação da outra parte.

Porém, o artigo 359 do referido anteprojeto previa a possibilidade de se evitar a revisão do contrato caso o réu se oferecesse, dentro do prazo para contestar, "a modificar com equanimidade o esquema de cumprimento do contrato". A legislação extraordinária recebeu, paulatinamente, uma maior intervenção estatal, buscando equilíbrio nas relações negociais, a exemplo da Lei de Usura, Lei de Locação de Imóveis, Lei de Economia Popular etc.

Ainda que anteriormente ao advento do Código Civil de 2002, a doutrina e a jurisprudência já admitiam ora a resolução contratual por onerosidade excessiva, ora a sua revisão, buscando maior equilíbrio nas relações negociais, principalmente diante de surtos inflacionários e dos planos econômicos levados a efeito pelo Governo Federal.

O primeiro julgamento favorável à tese revisionista foi reconhecidamente proferido por Nelson Hungria em 27 de outubro de 1930. No caso, a Ordem Terceira, denominada uma ordem monástica, havia locado por 25 anos um prédio de sua propriedade, situado no Rio de Janeiro. Uma das cláusulas do contrato previa que, dentro deste prazo de locação, o locatário poderia comprar a casa por vinte e cinco contos de réis. Entretanto, posteriormente, houve uma extraordinária valorização da região em que o imóvel se localizava, ao passo que apenas o terreno passou a valer mais do que oitocentos contos. A locadora invocou a impossibilidade de finalizar o negócio, pois surgira um fato inteiramente imprevisto e que a sua consumação importaria em intolerável desequilíbrio patrimonial. ${ }^{195}$

Na fundamentação de sua decisão, Nelson Hungria afirmou:

É certo que quem assume uma obrigação a ser cumprida em tempo futuro sujeita-se à alta de valores, que podem variar-se em seu proveito ou prejuízo; mas, no caso de uma profunda inopinada mutação, subversiva do equilíbrio econômico das partes, a razão jurídica não pode ater-se ao rigor literal do contrato, e o juiz deve pronunciar a rescisão deste. A aplicação da cláusula "rebus sic stantibus" tem sido mesmo admitida como um corolário da teoria do erro contratual.

Considera-se como já viciada ao tempo em que o vínculo se contrai a representação mental que só um evento vem e demonstra ser falsa. Se o evento, não previsto e imprevisível, modificativo da situação de fato na qual

${ }^{195}$ OLIVEIRA, Anísio José de. A cláusula “rebus sic stantibus”. Belo Horizonte: [s.n.], 1968. p. 94. 
ocorreu a convergência das vontades no contrato, é de molde a quebrar inteiramente a equivalência entre as prestações recíprocas, não padece dúvida que se a parte prejudicada tivesse o dom da paciência, não se teria obrigado, ou ter-se-ia obrigado sob condições diversas.

É o que acontece no caso "sub-judice".

O artigo 478 do Código Civil de 2002 contempla a onerosidade excessiva, estabelecendo que:

Nos contratos de execução continuada ou diferida, se a prestação de um das partes se tornar excessivamente onerosa, com extrema vantagem para a outra, em virtude de acontecimentos extraordinários e imprevisíveis, poderá o devedor pedir a resolução do contrato. Os efeitos da sentença, que o decretar, retroagirão à data da citação.

Nos mesmos moldes da legislação italiana (artigo 1.467, item 3), o artigo 479 do Código Civil de 2002 prevê que "A resolução poderá ser evitada, oferecendo-se o réu a modificar equitativamente as condições do contrato".

Álvaro Villaça Azevedo é ferrenho crítico do referido texto legal, aduzindo, em palestra proferida em Seminário realizado pela Câmara Federal dos Deputados, que a palavra “imprevisíveis" deveria ser eliminada do texto do artigo 478, para que se acolha somente a onerosidade excessiva, pura e simplesmente, ao invés da teoria da imprevisão, de difícil aplicação. ${ }^{196}$

Argumenta o autor que o Direito "não suporta o enriquecimento sem causa, seja por que motivo for", bastando o desequilíbrio econômico do contrato para que ele possa ser modificado ou resolvido, "em razão da simples ocorrência da onerosidade excessiva", independentemente de ser previsível ou não a alteração dos fatos. ${ }^{197}$

De acordo com José-Ricardo Pereira Lira, "É patente a adesão do Brasil à solução do direito italiano para o problema da alteração das circunstâncias contratuais". ${ }^{198}$

Também o artigo 317 do Código Civil prevê uma possibilidade de recuperação no equilíbrio contratual, quando, "por motivos imprevisíveis, sobrevier desproporção manifesta entre o valor da prestação devida e o do momento de sua execução, possibilitando ao juiz

\footnotetext{
${ }^{196}$ VILLAÇA AZEVEDO, Álvaro. O novo Código Civil Brasileiro: tramitação; função social do contrato; boafé objetiva; teoria da imprevisão e, em especial, onerosidade excessiva (Laesio enormis). In: TEPEDINO, Gustavo; FACHIN, Luiz Edson (Coord.). O Direito e o tempo: embates jurídicos e utopias contemporâneas. Rio de Janeiro: Renovar, 2008. p. 27.

${ }_{197}^{197}$ Ibid., p. 28.

198 PEREIRA LIRA, José-Ricardo. A onerosidade excessiva no Código Civil e a impossibilidade de "modificação judicial dos contratos comutativos sem anuência do credor". In: TEPEDINO, Gustavo; FACHIN, Luiz Edson (Coord.). O Direito e o tempo: embates jurídicos e utopias contemporâneas. Rio de Janeiro: Renovar, 2008. p. 445.
} 
corrigi-lo, a pedido da parte, de modo que assegure, quanto possível, o valor real da prestação".

A aplicação da onerosidade excessiva no Direito Brasileiro será melhor analisada no Capítulo V. 


\section{CAPÍtUlO IV \\ TEORIAS RELATIVAS À ALTERAÇÃO DAS CIRCUNSTÂNCIAS}

Várias teorias surgiram com o objetivo de fundamentar a aplicação da cláusula rebus sic stantibus, permitindo, destarte, a revisão dos contratos.

J. M. Othon Sidou faz interessante afirmação quanto ao retorno da cláusula rebus sic stantibus no século XX:

O princípio rebus sic stantibus foi semente lançada pelos filósofos estóicos; colhida por poucos jurisconsultos clássicos; semeada pelos salmistas e canonistas; brotada da jardinagem dos pós-glosadores; tornada arbusto em proveito do incipiente direito internacional; e, árvore quase morta pelo egoísmo individualista, reverdeceu com o adubo do suor humano para dar sombra aos que procuram abrigo no direito social. ${ }^{199}$

Sobre algumas dessas teorias, passa-se a discorrer.

\subsection{TEORIA DA PRESSUPOSIÇÃO DE WINDSCHEID}

Em meados do século XIX, Bernard Windscheid (1817/1892) elaborou sua teoria antes da entrada em vigor do BGB e por este não foi adotada, tendo profetizado: "É minha convicção firme que a pressuposição, tacitamente expressa, far-se-á sempre valer de novo, faça-se o que se fizer contra ela. Expulsa pela porta, ela volta pela janela". ${ }^{200}$

A teoria da pressuposição funda-se na hipótese de que "quem faz um contrato parte do pressuposto de que tudo ocorrerá normalmente e se, por acaso, isto não ocorrer a parte contrária não terá culpa, ela se desobriga". ${ }^{201}$

De acordo com Anísio José Oliveira, a pressuposição seria uma "condição não desenvolvida, uma limitação da vontade que não se desenvolve a ponto de ser uma condição"202, não sendo necessária qualquer disposição expressa a seu respeito, "porque

\footnotetext{
199 SIDOU, J. M. Othon. A Cláusula 'Rebus Sic Stantibus', Dos Efeitos da Fiança. Empresa Individual de responsabilidade limitada. Rio de Janeiro: Forense, 1978. p. 26.

${ }^{200}$ CORDEIRO, António Manuel da Rocha e Menezes. A boa-fé no Direito Civil. Coimbra: Almedina, 1984, p. 1032. (Colecção Teses, v. 1, T. II).

201 OLIVEIRA, Anísio José. A cláusula “rebus sic stantibus”. Belo Horizonte: [s.n.], 1968. p. 91.

${ }^{202}$ Nesse sentido, Otavio Luiz Rodrigues Júnior repete os ensinamentos de Windscheid: "La presupposizione è una condizione non isvolta (una limitazione della volontà), che non si è svolta fino ad essere una condizione. Chi manifesta un volere sotto uma presupposizione vuole, al par dicoluit Che emitte uma dichiarazione di
} 
admitia a pressuposição como da essência de qualquer relação negocial" ${ }^{203}$. Nestes termos, uma vontade negocial somente seria válida se existentes determinadas circunstâncias que o declarante considera como presentes. Caso a pressuposição não se realizasse, as consequências jurídicas corresponderiam à vontade declarada, mas não à vontade verdadeira.

Nas palavras de Mário Júlio de Almeida Costa, a teoria da pressuposição assentavase no postulado de que uma declaração de vontade negocial pode ser feita na convicção de que determinado estado de coisas se manterá, ou se tiverem ocorrido certos fatos pretéritos ou que ocorrerão determinados fatos no futuro de tal sorte que, de outra forma

[...] não se realizaria o negócio, ou a sua estipulação teria ocorrido em termos diversos; e o convencimento da verificação dessas circunstâncias ou facto é tão seguro, que nem mesmo se insere no contrato a cláusula correspondente, apresentando-se a pressuposição, portanto, como uma condição embrionária, ou não explicitada ou desenvolvida (<<eine unentwickelte Bedingung >>). ${ }^{204}$

Para esta teoria, o

[...] emitente da promessa, prejudicado pela falta de correspondência entre o que foi percebido ou era perceptível ao tempo da formação do vínculo e a realidade posterior, pode defender-se tanto por meio da exceção como de ação direta, qualquer delas destinadas a fazer cessar o efeito jurídico superveniente. ${ }^{205}$

A pressuposição esteve presente no artigo 742 do primeiro Projeto de Código Civil da Alemanha, mas, em razão das críticas de Lenel, não integrou o codex. ${ }^{206}$

Vários autores brasileiros, entre os quais Darcy Bessone, consideram a teoria da pressuposição a precursora das modernas teorias revisionistas. Entretanto, a teoria foi severamente criticada em razão de seu amplo caráter subjetivo e voluntarístico, pois a

volontá condizionata, che l'effeto giuridico voluto abbia ad esistere soltanto dato um certo stato dei rapporti; ma egli non giunge sino a far dipendere l'esistenza dell'effetto da questo stado dei rapporti. La conseguenza di cio è, che l'effetto giuridico voluto sussiste e perdura, sebbene venga meno la presupposizione. Ma cio non corrisponde al vero, proprio volere della'autore della dichiarazione di volontà, e quindi la sussistenza dell'effetto giuridico, sebbene formalmente giustificata, no ha però sostanzialmente ragione, che la giustifichi. In conseguenza di cio, colui, che à pregiudicato dalla dichiarazione di volontà, può tanto difendersi com l'eccezione contro le ragioni, che da essa si derivano, quando anche istituire a sua volta contro coui, a vantaggio del quale l'effetto giuridico ha avuto luogo, un'azione diretta a farto cessare" (RODRIGUES JÚNIOR, Otavio Luiz. Revisão judicial dos contratos. Autonomia da vontade e teoria da imprevisão. São Paulo: Atlas, 2006. p. 82).

203 BORGES, Nelson. A teoria da imprevisão no Direito Civil e no Processo Civil. São Paulo: Malheiros, 2002. p. 170.

${ }^{204}$ COSTA, Mário Júlio Almeida. Direito das obrigações. 9. ed. Coimbra: Almedina, 2003. p. 292.

${ }^{205}$ OLIVEIRA, Anísio José. A cláusula “rebus sic stantibus”. Belo Horizonte: [s.n.], 1968. p. 92.

206 ITURRASPE, Jorge Mosset; PIEDECASAS, Miguel A. La revisión del contrato. Santa Fe: Rubinzal Culzoni, 2008. p. 186-187. 
pressuposição "sequer necessitava ser manifestada externamente, bastando que a intenção pressuposta não se materializasse, tendo se entendido que tal contrariaria a firmeza das relações jurídicas negociais" ${ }^{207}$.

Além disto, a teoria foi criticada, pois, embora apoiada na cláusula rebus sic stantibus - que somente admitiria revisão na hipótese de uma alteração anormal futura da base contratual -, tinha alcance maior, na medida em que atingia situações passadas, presentes e futuras, fatos eventuais ou permanentes, positivos ou negativos ${ }^{208}$, e, ainda, não se restringira somente aos contratos, mas a todos os atos jurídicos obrigacionais de caráter patrimonial. $^{209}$

Para Medeiros da Fonseca ${ }^{210}$, a teoria da pressuposição é muito mais lata que a cláusula rebus sic stantibus, que não distinguiu causa e motivos subjetivos. Entretanto, a crítica está em trazer grande insegurança por provir de um unilateralismo, pois "era inteiramente desconhecido da outra parte, situação inaceitável nos contratos, por ser indiscutível que a eficácia jurídica das relações negociais independe dos motivos das partes, aspecto que pertence ao campo subjetivo". ${ }^{211}$

Nesse sentido, Lenel afirmava que "Semejante norma vendría a imponer a la parte contraria una condición que ella no había aceptado, ni la hubiera aceptado, quizá, en la mayoría de los casos, de haberse formulado la oferta condicionalmente". 212

Iturraspe e Piedecasas, fortes no pensamento de Lenel, afirmam que a pressuposição leva à confusão do que seja uma condição no sentido técnico e um puro motivo, que é irrelevante, além de se recair em um subjetivismo extremo, em especial em relação às alterações que não tenham sido pressupostas. $^{213}$

Abgar Soriano apontou os pontos vulneráveis da teoria da pressuposição: 1) o perigo de se confundir a causa com os motivos do ato jurídico, emprestando-se-lhes uma importância excessiva; 2) a eficácia de um contrato bilateral poder ser destruída por uma só das partes; 3 ) as pressuposições tácitas atentarem contra toda a estabilidade de operações jurídicas

207 CUNHA, Wladimir Alcibíades Marinho Falcão. Revisão judicial dos contratos: do Código de Defesa do Consumidor ao Código Civil de 2002. São Paulo: Método, 2007. p. 189-190.

${ }^{208}$ BORGES, Nelson. A teoria da imprevisão no Direito Civil e no Processo Civil. São Paulo: Malheiros, 2002. p. 171.

${ }^{209}$ SIDOU, J. M. Othon. A cláusula "Rebus sic stantibus” no Direito Brasileiro. Rio de Janeiro: Freitas Bastos, 1962. p. 38.

${ }^{210}$ FONSECA, Arnoldo Medeiros da. Caso fortuito e teoria da imprevisão. Rio de Janeiro: Forense, 1958. p. 203.

${ }^{211}$ BORGES, Nelson. Op. cit., p. 172-173.

${ }^{212}$ ITURRASPE, Jorge Mosset; PIEDECASAS, Miguel A. La revisión del contrato. Santa Fe: Rubinzal Culzoni, 2008. p. 188.

213 FRANTZ, Laura Coradini. Revisão dos contratos: elementos para sua construção dogmática. São Paulo: Saraiva, 2007. p. 41. 
concluídas. $^{214}$

Em exemplo de Paulo Nader ${ }^{215}$, considere-se a seguinte hipótese: um homem do interior, na certeza de que seu filho será aprovado no exame de vestibular, contrata a locação de um apartamento na cidade. Nas tratativas, poderiam ocorrer quatro situações relativamente ao motivo exposto: a) o locatário não revela o teor da sua vontade; b) esta foi expressa oralmente como motivo da locação; c) o locatário não declara expressamente a sua vontade, mas ela fica implícita pelo tipo de diálogo travado entre as partes contratantes; d) o motivo determinante é declarado como cláusula contratual escrita. Pergunta-se: se o filho do locatário não logra aprovação no concurso a que se submeteu, deixando de necessitar do apartamento para morar, qual o efeito jurídico de tal fato sobre o vínculo contratual estabelecido?

De acordo com o referido autor, nas três primeiras alternativas, tem-se a figura da pressuposição, a qual não possuiria o poder de invalidar o ato negocial. Já a quarta alternativa seria representativa de uma condição e não de pressuposição.

Karl Larenz também criticou esta teoria e deu o seguinte exemplo: o pai que tenha comprado um enxoval para sua filha, com a pressuposição conhecida do vendedor de que a filha brevemente se casaria. O pai não poderia resolver a compra se o planejado casamento não se realizasse, a não ser que tivesse erigido a realização do casamento à condição da compra e esta condição tivesse sido aceita pelo vendedor. Para o autor, não basta que uma parte tenha conhecido a pressuposição da outra: a parte deve anuir a que o contrato dependa da realização desta pressuposição, já que, do contrário, ser-lhe-ia imputado um contrato que talvez não tivesse querido celebrar.

Também com base no pensamento de Lenel, Larenz afirma que não há um termo médio entre um motivo irrelevante e a autêntica condição: ou bem a pressuposição deve configurar como condição de validade do contrato e deve ser aceita pela outra parte contratante, ou se reduz a um motivo juridicamente irrelevante. ${ }^{216}$

Cumprindo a sua profecia, a teoria de Windscheid voltou à cena jurídica por intermédio da primeira teoria da base do negócio formulada por Paul Oertmann ${ }^{217}$, sobre a qual se discorrerá na sequência.

\footnotetext{
${ }^{214}$ SIDOU, J. M. Othon. A cláusula "Rebus sic stantibus" no Direito Brasileiro. Rio de Janeiro: Freitas Bastos, 1962. p. 38.

${ }^{215}$ NADER, Paulo. Curso de Direito Civil - Parte Geral. Rio de Janeiro: Forense, 2004. p. 46.

${ }^{216}$ LARENZ, Karl. Base del Negocio Juridico y Cumplimiento de los Contratos. Granada: Comares, 2002, p. 1819.

${ }^{217}$ GODOY, Claudio Luiz Bueno de. A função social do contrato: os novos princípios contratuais. 3. ed. São Paulo: Saraiva, 2009. p. 57.
} 


\title{
4.2 TEORIA DA VONTADE MARGINAL DE GIUSEPPE OSTI
}

Giuseppe Osti criou a teoria da vontade marginal, segundo a qual a vontade, quando da feitura de um contrato, atua em dois tempos: presente e futuro.

\begin{abstract}
Assim, por exemplo, quando eu fôr cumprir o contrato acontece um imprevisto, alegarei o seguinte: êste negócio contraria a minha vontade, porque esta atuou em duas etapas: na primeira quando da realização do contrato e na segunda quando da execução "in futurum" esta minha vontade estacionária, em suspenso. Logo, essa deliberação tornou-se marginal e por isso mesmo, seria eu desvinculado da obrigação assumida. ${ }^{218}$
\end{abstract}

Osti distinguiu a vontade contratual, que é a vontade de obrigar-se, ato volitivo perfeito, acabado e determinado, da chamada vontade marginal, que é a vontade de realizar a prestação e que nasceria no momento da execução da prestação. Faltando correspondência entre a obrigação prometida e aquela que será cumprida, “a própria razão da tutela jurídica exige que seja suprimida a obrigação". 219

A vontade marginal não seria uma vontade definitiva e perfeita porque "pode ser modificada pela superveniência de eventos não conjeturados". 220

Osti $^{221}$ deduz alguns critérios gerais para aplicação concreta da superveniência, entre os quais: i) as representações individuais dos contraentes devem ser coligadas à vontade declarada, "no sentido de que a concreta realidade da prestação, a qual é individualizada no contrato, não possa ser diversamente representada por pessoas que se encontrem na posição e no ambiente social e econômico próprio do contraente em alvo"; ii) a superveniência deve ser imprevisível não só para aquele que tenha determinado sua vontade com base em uma representação disforme da efetiva realidade, mas também àquele cuja vontade tenha sido declarada; iii) o evento futuro imprevisível equivale ao evento já ocorrido, mas que é desconhecido como atual e imprevisível como futuro; iv) a superveniência pode relacionar-se tanto a um fato que ocorre quando era normal prever que não ocorresse quanto a um fato não ocorre quando era normal prever que ocorresse; v) a imprevisibilidade e a correspondente imprevisão da superveniência devem ser compreendidas em relação ao particular momento em que a prestação deve ser executada, pois somente este momento é relevante em relação à vontade contratual; vi) não é relevante a simples manifestação de uma representação toda

\footnotetext{
${ }^{218}$ OLIVEIRA, Anísio José. A cláusula “rebus sic stantibus”. Belo Horizonte: [s.n.], 1968. p. 95.

${ }^{219}$ Ibid., p. 96.

${ }^{220}$ MAIA, Paulo Carneiro. Da cláusula rebus sic stantibus. São Paulo: Saraiva, 1959. p. 169.

${ }^{221}$ OSTI, Giuseppe. Scritti Giuridici. Milano: Giuffrè, 1973. p. 321-327.
} 
subjetiva de um dos contratantes; vii) a superveniência que diverge a realidade concreta dos fatos da representação das partes não deve ser determinada pela ação ou omissão culposa daqueles que podem invocá-la; viii) a superveniência determina uma divergência da realidade concreta das coisas em confronto com a representação correspondente dos sujeitos, que, objetivamente, pode refletir de modo diverso sobre a economia desses mesmos sujeitos. Podese pensar em superveniência que se reflita vantajosamente sobre a economia de um e não se reflita totalmente sobre a do outro.

Esta teoria também não ficou ilesa a críticas, por ser subjetivista, "pois poderá ocorrer que $\mathrm{X}$ faça um contrato com $\mathrm{Y}$ e quando da realização dele, $\mathrm{X}$ pressentindo que não auferirá grandes vantagens simplesmente alegará, segundo essa teoria, como escusa essa segunda vantagem, isto é, a vontade marginal”. ${ }^{222}$

Nesse sentido, Nelson Borges faz menção ao pensamento de Elio Osilia, grande crítico do trabalho de Osti e que chegou a equiparar o posicionamento deste ao de Windscheid concluindo que "as representações que sustentavam a vontade marginal de Osti não se afastavam dos motivos contratuais de Windscheid, excluídos da proteção legal". ${ }^{223}$

Também a critica Pugliese ao afirmar que o contrato, uma vez celebrado, não pode ser resolvido pelo arbítrio de uma das partes e que são extensivas a esta teoria as mesmas críticas feitas à teoria da pressuposição de Windscheid. ${ }^{224}$

Sobre a teoria de Osti, Scognamiglio escreveu que a vontade marginal não pode constituir, na sua inteireza, objeto de consenso contratual porque as representações se moldam sob uma série de circunstâncias (o valor das prestações em relação à própria esfera econômica individual, a expectativa de imprimir certa destinação à contraprestação recebida) que podem, por exemplo, não ter uma coligação lógica necessária com a prestação objetivamente considerada. $^{225}$

\section{3 TEORIA DA VONTADE EFICAZ DE ERICH KAUFMANN}

A teoria da vontade eficaz foi desenvolvida por Erich Kaufmann, em 1911. Segundo esta teoria, a cláusula rebus sic stantibus rege os contratos "mesmo quando nenhum dos

\footnotetext{
${ }^{222}$ OLIVEIRA, Anísio José. A cláusula “rebus sic stantibus”. Belo Horizonte: [s.n.], 1968. p. 96.

${ }^{223}$ BORGES, Nelson. A teoria da imprevisão no Direito Civil e no Processo Civil. São Paulo: Malheiros, 2002. p. 177.

${ }^{224}$ PUGLIESE, Antonio Celso Fonseca. Teoria da imprevisão e o novo Código Civil. Revista dos Tribunais, São Paulo, v. 93, n. 830, p. 12-26, dez. 2004.

225 SCOGNAMIGLIO, Cláudio. Interpretazione del contratto e interessi dei contraenti. Casa Editrice Dott. Antonio Milani: Padova, 1992, p. 213.
} 
contratantes a haja acolhido em sua 'vontade empírica'. Disso resulta que a variação das circunstâncias deve ser tomada em conta quando se puser em prática a 'finalidade essencial do contrato", 226

Para Kaufmann, a obrigação assumida no negócio jurídico por cada contratante deve encontrar seus limites no que possa ser imputado ao contratante obrigado em virtude de sua vontade eficaz, tendente à finalidade essencial de um tipo contratual. A variação das circunstâncias deveria ser tomada em consideração quando se coloca em perigo a "finalidade essencial do contrato", como, por exemplo, quando resulte destruída a relação de equivalência entre prestação e contraprestação que exige a "finalidade essencial do contrato". ${ }^{227}$

Essa teoria também foi criticada por padecer dos mesmos vícios da teoria de Osti, "uma vez que persistimos manifestando-nos infensos à dualidade volitiva num só ato continuado. No instante da conclusão do contrato, ou há vontade estável, suscetível embora de eventos imprevistos, ou tudo não terá passado de engodo. O contrato deixaria de ser um instrumento de segurança mútua para constituir prelibação esconsa em busca de vantagens desonestas". 228

\subsection{TEORIA DA RESERVA VIRTUAL DE PAUL KRÜCKMANN}

Após a I Guerra Mundial e, ainda durante o conflito, Paul Krückmann defendeu a validade prática da cláusula rebus sic stantibus e a conceituou como uma "reserva virtual",229. Esta reserva virtual seria considerada "uma limitação da própria vontade, manifestada expressa ou tacitamente - <<eu não concordaria se não aceitasse que...>> - ou não manifestada, mas imanente". 230

A cláusula rebus sic stantibus seria considerada uma "reserva virtual" porque ainda que as partes não tivessem conhecimento dela, a cláusula é imanente à sua vontade negocial, a não ser que a excluam expressamente. ${ }^{231}$

Nas palavras de Carvalho Fernandes, Krückmann entendia que não se pode psicologicamente considerar certo que a limitação da vontade à verificação de certas

\footnotetext{
${ }^{226}$ SIDOU, J. M. Othon. A cláusula “Rebus sic stantibus” no Direito Brasileiro. Rio de Janeiro: Freitas Bastos, 1962. p. 41.

${ }^{227}$ LARENZ, Karl. Base del Negocio Juridico y Cumplimiento de los Contratos. Granada: Comares, 2002. p. 26.

${ }^{228}$ SIDOU, J. M. Othon. Op. cit., p. 41.

${ }^{229}$ LARENZ, Karl. Op. cit., p. 26.

${ }^{230}$ CORDEIRO, António Manuel da Rocha e Menezes. A boa-fé no Direito Civil. Coimbra: Almedina, 1984. p. 1037. (Colecção Teses, v. 1, T. II).

231 MALDONADO, María Carreras. Revisión del contrato por cambio extraordinário. Disponível em: http://biblio.juridicas.unam.mx/libros/3/1022/6.pdf. Acesso em: 20 mar. 2012. p. 39-40.
} 
circunstâncias constitui a vontade real do declarante. O que poderia acontecer "é que essa limitação esteja virtualmente contida nas suas declarações, no sentido de que, se o agente pudesse ter previsto a não verificação de certa circunstância, não quereria o negócio". ${ }^{232}$

Esta teoria não se afasta da teoria de Windscheid, apenas a alarga, pois considera ínsito em todos os contratos um princípio de equivalência entre as prestações ou entre as prestações e a vantagem auferida pela parte que a presta.

\title{
4.5 TEORIA DA BASE SUBJETIVA DO NEGÓCIO JURÍDICO DE PAUL OERTMANN
}

Paul Oertmann procurou dar uma noção mais objetiva de base do negócio jurídico, definindo-a como

\begin{abstract}
A representação mental de uma das partes no momento da conclusão do negócio jurídico, conhecida em sua totalidade e não rechaçada pela outra parte, ou a representação comum das diversas partes sobre a existência ou aparecimento de certas circunstâncias, nas quais se baseia a vontade negocial. ${ }^{233}$
\end{abstract}

Haveria, portanto, um fato do conhecimento das partes, certo e determinado, a que Oertmann chamou de base do negócio. A base do negócio (Geschäfstgrundlage), por seu turno, seria “o reconhecimento da existência de circunstâncias essenciais, presentes na conclusão do pacto, aceitas pelas partes como circundantes do acordo contratual. Entre elas, a equivalência entre prestação e contraprestação". 234

De acordo com este posicionamento, se houvesse falha dessa representação, em virtude de fatos supervenientes à contratação, assistiria à parte prejudicada o direito de resolver ou denunciar o negócio. ${ }^{235}$

Para elucidar o seu posicionamento, Oertmann citado por Nelson Borges, exemplificou: imagine-se que Fritz e Karl são comerciantes de calçados na mesma cidade. Com o objetivo de ficar sozinho na área, o primeiro propõe ao segundo o afastamento de suas atividades por determinado tempo por eles avençado, mediante pagamento de certa quantia.

\footnotetext{
${ }^{232}$ CARVALHO FERNANDES, Luís A. A teoria da imprevisão no Direito Civil português. Lisboa: Quid Juris?, 2001. p. 65.

${ }^{233}$ CUNHA, Wladimir Alcibíades Marinho Falcão. Revisão judicial dos contratos: do Código de Defesa do Consumidor ao Código Civil de 2002. São Paulo: Método, 2007. p. 191.

${ }^{234}$ BORGES, Nelson. A teoria da imprevisão no Direito Civil e no Processo Civil. São Paulo: Malheiros, 2002. p. 178-179.

${ }^{235}$ CUNHA, Wladimir Alcibíades Marinho Falcão. Op. cit., p. 191.
} 
Firmado o contrato, Karl cessa suas atividades obedecendo ao contrato, recebendo por este adimplemento as quantias mensais pactuadas. Depois de algum tempo Fritz decide se retirar do comércio. Segundo o entendimento de Oertmann, cessada estava a obrigação de Fritz não sendo mais necessários os pagamentos mensais, e Karl poderia voltar ao comércio de calçados, pois com a retirada de Fritz do mercado "a contratação que era baseada em determinadas circunstâncias (eliminar a concorrência) deixou de existir, não representando mais o pactuado o que as partes primitivamente desejaram". 236

Larenz, entretanto, rebate a teoria de Oertmann analisando um julgado do Tribunal de Apelação de Postdam. No caso, o demandante havia vendido um caminhão aos demandados por um preço fixo no começo de 1940, reservando-se o direito de retrovenda do veículo depois do fim da guerra pelo preço oficialmente fixado. Em fevereiro 1946, o vendedor/demandante exerceu o direito de retrovenda, negando-se os demandados a entregar o caminhão. Tanto em primeira instância, quanto em segunda instância, a demanda foi rechaçada. Os demandados insurgiram-se contra a pretensão do demandante sob o argumento de que este não poderia fundamentar sua pretensão no acordo firmado porque resultara ineficaz em decorrência do desaparecimento da base do negócio.

Para eles, entre as considerações que levaram à conclusão do contrato não figuravam representações mentais sobre o final da guerra. Ainda porque deveria ser considerado que as partes, em 1940, estimavam que o final da guerra ocorreria em data anterior à que ocorreu. Ao criarem o direito de retrovenda, somente teria sentido a sua aplicação durante um breve lapso de tempo. Considerando-se que a duração normal do veículo seria de cinco anos, as partes não teriam previsto, de modo algum a retrovenda ao final de oito anos. Se os demandados tivessem que revender o veículo ao preço atualmente fixado, isto significaria a ruína econômica, pois o caminhão, dentro de sua empresa, representa um valor sensivelmente superior ao preço oficial, sem considerar o preço no mercado negro. As circunstâncias do momento em que a retrovenda seria exercida eram tão distintas das previstas pelas partes ao firmar o contrato que seria contrário ao princípio da boa-fé que os demandados ficassem vinculados ao acordo. As partes partiram do pressuposto de que, ao revender o veículo, subsistiriam mais ou menos, as circunstâncias econômicas existentes na época de sua transmissão. ${ }^{237}$

Neste julgado, Larenz entendeu não ser possível se falar em desaparecimento da base

\footnotetext{
${ }^{236}$ BORGES, Nelson. A teoria da imprevisão no Direito Civil e no Processo Civil. São Paulo: Malheiros, 2002. p. $179-180$.

${ }^{237}$ LARENZ, Karl. Base del negócio jurídico y cumplimiento del contrato. Granada: Comares, 2002. p. 6.
} 
do negócio, pois seria necessário ter em conta, primeiramente, a suposta representação mental das partes sobre um fim da guerra muito anterior à data em que ocorreu, e na sentença, não houve a menção de que as partes realmente tivessem tal representação. Para ele, não seria suficiente a representação ou a esperança de que as circunstâncias econômicas permaneceriam aproximadamente invariáveis. Se assim fosse, todos os contratos concluídos antes da superveniência de transtornos econômico-sociais imprevistos e ainda não cumpridos integralmente, ao sobrevirem aqueles, seriam considerados carentes da base do negócio. ${ }^{238}$

Para J. M. Othon Sidou, a diferença entre a teoria da pressuposição e a teoria de Oertmann é que "naquela, a pressuposição é unilateral, ou de uma só das partes, ao passo que a 'teoria da base do negócio jurídico' assenta não em reservas mentais isoladas, mas erige a pressuposição como um de seus fatores, como intenções subjetivas recíprocas. Trata-se agora de uma pressuposição, melhor dizer, um subentendimento bilateral". ${ }^{239}$

No mesmo sentido é o posicionamento de Wladimir Alcibíades Marinho Falcão $\mathrm{Cunha}^{240}$, ao afirmar que esta teoria difere da teoria da pressuposição de Windscheid somente pela exigência do conhecimento e da concordância, ainda que tácita, da motivação contratual do outro contratante. Enquanto isso, Nelson Borges sustenta que a diferença está no fato de que na teoria de Windscheid "a pressuposição consubstancia parte de uma declaração independente", enquanto que, na teoria da base do negócio jurídico, "a relação é direta com o negócio como um todo". ${ }^{241}$

A teoria de Oertmann não ficou ilesa às críticas. Lenel sustentava que era semelhante à teoria da pressuposição; Carneiro Maia afirmava que a sua aceitação seria decretar o fim da estabilidade dos negócios jurídicos ${ }^{242}$; Anísio José de Oliveira sustentou que a teoria é acusada de pouca objetividade, "de viver na via-láctea do direito", que é muito ampla ${ }^{243}$. J. M. Othon Sidou, por sua vez, afirma que a teoria repousa num "denso conteúdo subjetivo, tornando-se de aplicação difícil em face de determinadas relações e exigindo do juiz um dilatado espírito de diligência que às vezes extralimita a faculdade inquisitiva autorizada pelo moderno procedimento". 244

\footnotetext{
${ }^{238}$ LARENZ, Karl. Base del negócio jurídico y cumplimiento del contrato. Granada: Comares, 2002. p. 7.

${ }^{239}$ SIDOU, J. M. Othon. A cláusula "Rebus sic stantibus" no Direito Brasileiro. Rio de Janeiro: Freitas Bastos, 1962. p. 42.

${ }^{240}$ CUNHA, Wladimir Alcibíades Marinho Falcão. Revisão judicial dos contratos: do Código de Defesa do Consumidor ao Código Civil de 2002. São Paulo: Método, 2007. p. 192.

${ }^{241}$ BORGES, Nelson. A teoria da imprevisão no Direito Civil e no Processo Civil. São Paulo: Malheiros, 2002. p. 178

${ }^{242}$ Ibid., p. 181.

243 OLIVEIRA, Anísio José. A cláusula “rebus sic stantibus”. Belo Horizonte: [s.n.], 1968. p. 101.

${ }^{244}$ SIDOU, J. M. Othon. A cláusula "Rebus sic stantibus" no Direito Brasileiro. Rio de Janeiro: Freitas Bastos, 1962. p. 44.
} 
Larenz, por sua vez, afirmou que esta teoria não assinala de modo satisfatório quais são as circunstâncias que podem ser consideradas como "base" de um contrato e cujo imprevisto desaparecimento faça com que a relação contratual não possa subsistir ou manterse inalterada. ${ }^{245}$

\subsection{TEORIA DA BASE OBJETIVA DO NEGÓCIO JURÍDICO DE KARL LARENZ}

O jurista alemão Karl Larenz desenvolveu a chamada teoria da base objetiva, na qual distinguiu a base subjetiva da base objetiva. A base negocial subjetiva "traduziria a representação, pelas partes, no fecho do contrato, dos factores que tenham tido um papel dominante no seu processo de motivação" ${ }^{\text {246 }}$ e deveria ser objeto de análise à luz da teoria do erro e dos vícios consensuais. ${ }^{247}$ Já base objetiva corresponderia "ao conjunto das circunstâncias cuja existência ou manutenção, com ou sem consciência das partes, seria necessária para a salvaguarda do sentido contratual e do seu escopo". ${ }^{248}$

Larenz distinguiu a base negocial objetiva em duas hipóteses: a primeira, relativa à destruição da relação de equivalência das prestações em razão de ocorrências supervenientes, e outra referente à frustração do escopo contratual.

A primeira hipótese teria lugar quando a relação de equivalência entre prestação e contraprestação pressuposta no contrato tenha sido destruída em tal medida que não seja possível se falar racionalmente de uma contraprestação. ${ }^{249}$ A segunda hipótese reflete a situação em que a prestação é possível, mas não pode realizar-se o resultado que, segundo o contrato, se esperava da prestação, a qual, em consequência, não tem um fim ou objeto. ${ }^{250}$

A teoria de Larenz recebeu críticas. Menezes Cordeiro ${ }^{251}$, por exemplo, cita Blomeyer, para quem é estranha a repartição entre perturbação na equivalência das prestações e frustração do fim do contrato, pois estariam "excluídos todos os riscos estranhos ao contrato em si”. O autor se refere, ainda, a Esser, para quem não seria possível cindir a base do negócio em objetiva e subjetiva: na base objetiva, "a consideração de que ela estaria frustrada quando o contrato, mercê das alterações, não fizesse sentido, implica um regresso não

\footnotetext{
${ }^{245}$ LARENZ, Karl. Base del negócio jurídico y cumplimiento del contrato. Granada: Comares, 2002. p. 17.

${ }^{246}$ CORDEIRO, António Manuel da Rocha e Menezes. A boa-fé no Direito Civil. Coimbra: Almedina, 1984. p. 1046. (Colecção Teses, v. 1, T. II).

247 RODRIGUES JÚNIOR, Otávio Luiz. Revisão judicial dos contratos. Autonomia da vontade e teoria da imprevisão. São Paulo: Atlas, 2006. p. 83.

${ }^{248}$ CORDEIRO, António Manuel da Rocha e Menezes. Op. cit., p. 1048.

${ }^{249}$ LARENZ, Karl. Op. cit., p. 211.

${ }^{250}$ Ibid., p. 92.

${ }^{251}$ CORDEIRO, António Manuel da Rocha e Menezes. Op. cit., p. 1048.
} 
assumido à vontade das partes"; na subjetiva, "a utilização de intenções e pressuposições comuns das partes torna-se impraticável sem introduzir critérios objectivos".

Para concluir seu posicionamento, Menezes Cordeiro afirma que a base do negócio de Larenz "não exprime nem uma doutrina portadora de soluções, nem um espaço problemático claro, para o qual se alinhem saídas várias". 252

\subsection{TEORIA DO DEVER DE ESFORÇO DE HARTMANN}

Para fundamentar a aplicação da cláusula rebus sic stantibus, Hartmann criou a teoria que denominou "dever de esforço" ou, ainda, "prestação de diligência". Hartmann propunha que "Quando duas pessoas contratam, surge uma relação jurídica entre elas. Ambas são dotadas de um dever jurídico. Êste dever jurídico que consiste na obrigação de dar, fazer ou não fazer, foi substituído por Hartmann por dever de esforço". 253

Portanto, o que é objeto de análise não é a prestação, mas sim se as partes se esforçaram para realizá-la. Neste sentido, não há que se pesquisar a culpa da parte ou a impossibilidade no cumprimento do contrato, mas apenas se o devedor se dedicou com afinco para realizar a prestação. Se houve dedicação ou esforço por parte do devedor para cumprir a prestação, mas devido ao obstáculo superveniente não o conseguir, ele estará liberado pela cláusula rebus sic stantibus. Ou seja, "Não se há de investigar a culpa ou a impossibilidade, mas tão somente o ânimo, a energia, o trabalho desenvolvido, a energia dispensada pelo promitente a fim de prestar a obrigação. Aí já não mais haverá vinculação de qualquer espécie!". 254

A teoria por dever de esforço também recebeu críticas. A principal está no fato de

\footnotetext{
${ }^{252}$ Larenz afirma: "Há que se ir mais longe na crítica a LARENZ, examinando, do ponto de vista do conteúdo, as realidades dogmáticas por ele incluídas na base do negócio. Retenha-se apenas, para já, que LARENZ, explicitamente, introduziu, no seio da categoria <<base do negócio〉>, previsões normativas diferentes. Tratase de um fenómeno de difusão horizontal, prenunciado, em período anterior, pelos críticos de OERTMANN, e, em especial, por LOCHER, e acentuado pela recepção verbal operada pelo Tribunal do Reich: visando resolver uma certa problemática, a base do negócio vai abranger questões diversas, com base em conexões não científicas ou menos científicas. O fenómeno é dinamizado, também, pela facilidade aparente que acarreta, a nível de solução: a saída segundo a boa fé. Essa difusão horizontal completa-se, a nível científico, por um esvaziamento dogmático crescente. Em OERTMANN, a base do negócio era uma doutrina pensada para solucionar problemas postos nos contratos por alterações supervenientes de circunstâncias; posteriormente, a mesma expressão veio a ser utilizada para designar doutrinas distintas, dirigidas para os mesmos problemas; a concluir, ela traduz proposições irredutíveis, no âmbito como na solução. No termo, a base do negócio não exprime nem uma doutrina portadora de soluções, nem um espaço problemático claro, para o qual se alinhem saídas várias. Desacompanhada de perífrases, a base do negócio, desde os últimos trinta anos, pouco quer dizer. É uma fórmula dogmática vazia" (CORDEIRO, António Manuel da Rocha e Menezes. A boa-fé no Direito Civil. Coimbra: Almedina, 1984. p. 1050. (Colecção Teses, v. 1, T. II).

${ }^{253}$ OLIVEIRA, Anísio José. A cláusula "rebus sic stantibus". Belo Horizonte: [s.n.], 1968. p. 107.

${ }^{254}$ OLIVEIRA, Anísio José. A cláusula "rebus sic stantibus". Belo Horizonte: [s.n.], 1968. p. 107.
} 
que, quando uma pessoa firma um contrato, ela o faz com o intuito precípuo de cumpri-lo, ao passo que a teoria não se aplica às obrigações de resultado, mas apenas às obrigações de meio. ${ }^{255}$ Também ao criticar a teoria, Othon Sidou afirmou que ela "se deixa dominar por fatores exógenos e facilmente resvala para o caso fortuito, ou força maior". ${ }^{256}$ Já Arnoldo Medeiros da Fonseca, forte no pensamento de Giovene, afirma que a teoria de Hartmann, adotando o princípio da liberação do devedor sempre que ele tenha exaurido o esforço que, no caso concreto, seja imposto pelo dever jurídico à sua atividade para consecução do escopo da obrigação, ainda que não seja conseguido, "vai além da atenuação do conceito de impossibilidade, eliminando-a mesmo, como requisito a ser levado em conta". ${ }^{257}$

\subsection{A CLÁUSULA REBUS SIC STANTIBUS COM FUNDAMENTO NA MORAL}

Georges Ripert, na primeira metade do século XX, fundamentou a aplicação da cláusula rebus sic stantibus na moral. Para o jurista, o princípio da imprevisão descansa na moral: "não deve o credor usar de seus direitos com excessivo rigor, pois constituiria uma suprema injustiça, isto é, de modo algum o credor está obrigado a praticar as suas razões com total e enorme aspereza, já que isto tornaria a justiça iníqua, díspara". ${ }^{258}$ A execução do contrato defeituoso, para Ripert, seria imoral, possibilitando a revisão ou resolução do contrato, conforme as condições inicialmente contratadas sejam tão onerosas e desproporcionais que iriam contra a moral. Para o autor, aplica-se a regra moral Summus jus, summa injuria, hipótese em que, se o credor esgotasse o seu direito, causaria à outra parte um grave prejuízo. $^{259}$

Esta teoria foi criticada porque o conceito de moral é variável. Nas palavras de Anísio José de Oliveira, "Há uma moral cristã como há uma moral budista ou para os ateus. Para os marxistas é moral o que está de acordo com o interesse, com a finalidade do Estado. Em moral, como para quase todas as coisas, tudo é relativo; de absoluto nada existe". ${ }^{260}$

No mesmo sentido, Menezes Cordeiro afirmou que o recurso à moral representa

\footnotetext{
${ }^{255}$ OLIVEIRA, Anísio José. A cláusula “rebus sic stantibus”. Belo Horizonte: [s.n.], 1968. p. 108-109.

${ }^{256}$ SIDOU, J. M. Othon. A cláusula "Rebus sic stantibus” no Direito Brasileiro. Rio de Janeiro: Freitas Bastos, 1962. p. 45.

${ }^{257}$ FONSECA, Arnoldo Medeiros da. Caso fortuito e teoria da imprevisão. Rio de Janeiro: Forense, 1958. p. 101.

${ }^{258}$ OLIVEIRA, Anísio José. Op. cit., p. 119.

${ }^{259}$ RIPERT, Georges. A regra moral nas obrigações civis. Campinas: Bookseller, 2000. p. 152.

${ }^{260}$ OLIVEIRA, Anísio José. Op. cit., p. 120.
} 
"uma problemática mais difícil do que as questões que pretende resolver". 261

J. M. Othon Sidou fez sua crítica afirmando que a moral não pode, de forma isolada, explicar uma teoria obediente ao bonum et aequum, "porque assim iria não só superfluamente qualificar todas as regras jurídicas - resultantes do justo e do necessário - como também nos deixaria envolvidos num conceito circunvago". ${ }^{262}$ Neste sentido, Carvalho Fernandes afirma que "Pode ser certo que a imprevisão esteja de acordo com os princípios da moral, mas servirnos desta para explicar a sua aceitação pelo direito é desviar o problema". ${ }^{263}$

\subsection{A CLÁUSULA REBUS SIC STANTIBUS COM FUNDAMENTO NA BOA-FÉ}

Segundo Anísio José de Oliveira, Wendt baseou-se na boa-fé para explicar a necessidade da rescisão ou revisão contratual quando circunstâncias supervenientes impedissem o cumprimento normal da obrigação. De acordo com este posicionamento, a boafé seria a "explicação mais convincente para a justificação da cláusula "rebus sic stantibus", tendo em vista que não caberia ao legislador o que possa acontecer no desenrolar do contrato. Assim, a boa-fé seria a espada da Justiça, "como segurança para a aplicação do direito ao caso concreto", uma "válvula de segurança" para a convincente aplicação do direito ao caso concreto. $^{264}$

De acordo com Carvalho Fernandes, o raciocínio dos defensores da boa-fé como fundamento da rescisão dos contratos por alteração das circunstâncias estrutura-se da seguinte forma: "todos os contratos devem ser cumpridos de boa fé; ora, procede de má fé o credor que reclamar do devedor a execução do contrato, cujas condições se transformaram de tal modo que impõe ao devedor encargos imprevistos". ${ }^{265}$

Esta teoria também recebeu críticas. Medeiros da Fonseca sustentou que o conceito de boa-fé é muito vago, "cujos elementos, no próprio dizer de WENDT, pertencem às noções imponderáveis" 266 , em um posicionamento que foi corroborado por Anísio José de Oliveira. $^{267}$

${ }^{261}$ CORDEIRO, António Menezes. A boa-fé no Direito Civil. Coimbra: Almedina, 1984. p. 963. (Colecção Teses, v. 1, T. II).

${ }^{262}$ SIDOU, J. M. Othon. A cláusula "Rebus sic stantibus" no Direito Brasileiro. Rio de Janeiro: Freitas Bastos, 1962. p. 35.

${ }^{263}$ CARVALHO FERNANDES, Luís A. A teoria da imprevisão no Direito Civil português. Lisboa: Quid Juris?, 2001. p. 39.

${ }^{264}$ OLIVEIRA, Anísio José. A cláusula “rebus sic stantibus". Belo Horizonte: [s.n.], 1968. p. 122.

${ }^{265}$ CARVALHO FERNANDES, Luís A. Op. cit., p. 35.

${ }^{266}$ FONSECA, Arnoldo Medeiros da. Caso fortuito e teoria da imprevisão. Rio de Janeiro: Forense, 1958. p. 217-218.

${ }^{267}$ OLIVEIRA, Anísio José. Op. cit., p. 122. 
Segundo Othon Sidou, fazer da boa-fé o "supedâneo para a cláusula revisionista é de uma vacuidade desmesurada, acaso não resultasse em patente tautologia, uma vez que o contrato só pode ter por fim objeto lícito, como ato jurídico que é". ${ }^{268}$

Refutando a crítica de que o conceito de boa-fé é vago, Eugenio Osvaldo Cardino lembrou os ensinamentos de Atienza Dalmiro Alsina, ao afirmar que mais vago ainda é o conceito de moral ou de justo, e que não foi encontrado outro que melhor solucione os interesses em jogo. $^{269}$

${ }^{268}$ SIDOU, J. M. Othon. A cláusula "Rebus sic stantibus" no Direito Brasileiro. Rio de Janeiro: Freitas Bastos, 1962. p. 34.

${ }^{269}$ CARDINI, Eugenio Oswaldo. La teoría de la imprevisión. Buenos Aires: Abeledo-Perrot, 1937. p. 199. 


\section{CAPÍtULO V}

\section{A ALTERAÇÃo DAS CIRCUNSTÂNCIAS NO CÓDIGO CIVIL BRASILEIRO}

Havendo a alteração das circunstâncias em que o contrato foi celebrado, o ideal seria que as próprias partes contratantes, prevendo a possibilidade desta alteração, já dispusessem no contrato quais as suas consequências. Entretanto, como afirma Melvin A. Eisenberg, forte no pensamento de Herbert Simon, a capacidade da mente humana para formular e solver problemas complexos é muito pequena se comparada ao tamanho dos problemas cuja solução é requisita no mundo real. ${ }^{270}$

$\mathrm{Na}$ ausência de estipulação entre as partes, outros instrumentos são utilizados para restabelecer o equilíbrio do contrato ${ }^{271}$, uma temática de grande importância, principalmente nos dias atuais que seguem uma grande recessão na economia mundial desde 2008.

A alteração das circunstâncias contratuais não foi representada no Código Civil de 1916, o qual, como já visto, recebeu grande influência do pensamento liberal. Em razão disto, os contratos, uma vez firmados, faziam lei entre as partes de sorte que deveriam ser cumpridos ainda que houvesse uma alteração fática que levasse a uma desproporção nas prestações avençadas.

Entretanto, como já dito anteriormente, a mudança de um Estado Liberal para um Estado Social, em que se prima pela igualdade e pela solidariedade, e principalmente com o advento das Grandes Guerras, quando a preocupação com a tutela da dignidade da pessoa humana passou a ser imperiosa, não mais se admitia que as relações contratuais fossem espoliativas e iníquas.

Nos contratos de execução diferida ou continuada, a preocupação com a equivalência das prestações mostra-se ainda mais relevante, pois, com o passar do tempo, as circunstâncias em que o contrato foi celebrado podem se alterar de forma a modificar o equilíbrio contratual.

Nas palavras de Ricardo Luiz Lorenzetti, utilizando o conceito de obrigação como processo, tem-se que

[...] un contrato de larga duración no es sino un acuerdo provisorio, sometido a permanentes mutaciones. La obligación es concebida como

\footnotetext{
${ }^{270}$ EISENBERG, Melvin A. Impossibility, impracticability and frustration. Journal of Legal Analysis, Winter, 2009, v. 1, n. 1, p. 213. Disponível em: http://ssrn.com/abstract=1349482. Acesso em: 24 abr. 2012.

${ }^{271}$ RÖSLER, Hannes. Hardship in German Codified Private Law. Hardship in German Codified Private Law. In Comparative Perspective to English, French and International Contract Law. European Review of Private Law, v.15, n. 4, 2007, p. 484.
} 
proceso, con un continuum desarrollado en el tiempo que todo lo domina. Por ello Morello indica que el contrato de duración requiere una permanente adaptación, una cooperación renegociadora continua. Frente a este fenómeno surge el dilema de encontrar fórmulas que armonicen la necesidad de adaptación a los cambios, la seguridad jurídica frente a las modificaciones ulteriores de lo pactado y la prevención de prácticas abusivas que a través de modificaciones unilaterales alteren la relación de equivalencia. ${ }^{272}$

O Código Civil de 2002 tratou do equilíbrio nas relações negociais em dois momentos. Primeiramente no artigo 317, ao tratar do "objeto do pagamento" nas obrigações em geral, e posteriormente nos artigos 478 a 480, ao tratar da "resolução por onerosidade excessiva" na relação contratual.

Os artigos 478 a 480 estão inseridos sistematicamente na Seção IV do Capítulo II do Título V do Livro I da Parte Especial do Código Civil, portanto, em um capítulo que trata da extinção dos contratos.

Já pela opção do legislador por inserir a onerosidade excessiva em um capítulo que trata da extinção dos contratos, o instituto merece críticas, pois, conforme se analisará, a onerosidade excessiva não acarretará apenas a resolução do contrato, mas também, e preferencialmente, a sua modificação, até mesmo como forma de aplicação do princípio da conservação dos contratos, conforme será melhor analisado no item 5.2 deste capítulo.

Mesmo porque parece razoável conceber-se que as partes queiram que o contrato seja cumprido e não que queiram desistir do contrato, "eis que a finalidade central de toda relação obrigacional é de ser adimplida" ${ }^{273}$ Certifique-se que, inclusive, o artigo $3^{\circ}$ do Projeto de Lei n. 276/2007 visa alterar a denominação dada ao referido Capítulo II do Título V do Livro I da Parte Especial do Código Civil de "Da Extinção do Contrato" para "Da Revisão e da Extinção do Contrato".

A onerosidade excessiva não se confunde com a teoria da imprevisão, embora, no Brasil, a onerosidade excessiva envolva a teoria da imprevisão, porque, para a revisão contratual, não basta a onerosidade excessiva, "é preciso ainda verificar se os fatos supervenientes são, além de extraordinários, imprevisíveis", conforme se infere da redação do artigo 478 do Código Civil. ${ }^{274}$

\footnotetext{
${ }^{272}$ LORENZETTI, Ricardo. Tratado de los contratos. Tomo I. Buenos Aires: Rubinzal - Culzoni, 2004. p. 115116.

${ }^{273}$ CUNHA, Wladimir Alcibíades Marinho Falcão. Revisão judicial dos contratos: do Código de Defesa do Consumidor ao Código Civil de 2002. São Paulo: Método, 2007. p. 220.

${ }^{274}$ AZEVEDO, Antonio Junqueira de. Relatório brasileiro sobre a revisão contratual apresentado para as Jornadas Brasileiras da Associação Henri Capitant. In São Paulo: Saraiva, 2009, p. 184. . Novos estudos e pareceres de direito privado.
} 


\subsection{REQUISITOS POSITIVOS}

Para a aplicação da disciplina pertinente à onerosidade excessiva, vislumbra-se nos artigos 478 a 480 do Código Civil a necessidade da presença de alguns requisitos, quais sejam: i) que se trate de um contrato de execução continuada ou diferida; ii) onerosidade excessiva; iii) acontecimentos extraordinários e imprevisíveis; iv) extrema vantagem. Sobre tais requisitos passa-se a discorrer.

\subsubsection{Contratos de execução continuada, sucessiva ou diferida}

O artigo 478 do Código Civil exige para a resolução do contrato por alteração das circunstâncias por onerosidade excessiva que se esteja diante de contratos de execução continuada ou diferida.

É assente, entretanto, na doutrina que o disposto no artigo 478 mereça uma interpretação extensiva para abarcar também os contratos de trato sucessivo ou periódico. ${ }^{275}$ Necessário, portanto, tecerem-se alguns esclarecimentos a respeito destas classificações dos contratos.

Os contratos serão instantâneos ou de execução única quando suas prestações puderem ser realizadas em um só instante. Tais contratos podem dividir-se em "contratos instantâneos de execução imediata", isto é, a execução se dá imediatamente após a sua conclusão, e "contratos instantâneos de execução diferida", quando a execução é protraída para outro momento em virtude de uma cláusula que a subordina a um termo. ${ }^{276}$

Segundo Orlando Gomes, os contratos instantâneos de execução diferida dependem do futuro e, em razão disto, são aplicadas as "regras deduzidas pela teoria da imprevisão, que intuitivamente, não cabem nos contratos de execução imediata". 277

Os contratos instantâneos não se confundem com os contratos de duração que são aqueles "que constituem a categoria oposta à dos contratos de execução única". ${ }^{278}$ Nos contratos de duração (também chamados contratos de trato sucessivo ou contratos de execução continuada), a execução não pode cumprir-se num só instante, em razão de sua própria natureza.

Segundo Orlando Gomes,

\footnotetext{
275 CARDOSO, Luiz Philipe Tavares de Azevedo. A onerosidade excessiva no Direito Civil Brasileiro. Dissertação (Mestrado) - Universidade de São Paulo, São Paulo, 2010. p. 88.

${ }^{276}$ GOMES, Orlando. Contratos. Rio de Janeiro: Forense, 2007. p. 79.

277 Ibid., p. 81.

${ }^{278}$ Ibid., p. 79.
} 
Os contratos de duração subdividem-se em contratos de execução periódica e contratos de execução continuada. Os contratos de execução periódica, que se executam mediante prestações periodicamente repetidas, seriam, propriamente, os contratos de trato sucessivo, expressão que se emprega, aliás, incorretamente, para designar todos os contratos de duração, que se executam mediante prestações periodicamente repetidas. Os de execução continuada, aqueles em que a prestação é única, mas ininterrupta. Acrescentam alguns terceira classe, constituída pelos contratos de execução salteada, sob solicitação de uma das partes. ${ }^{279}$

Para este mesmo autor, a melhor denominação seria "contrato de duração", não obstante reconheça que engloba todas as subespécies teóricas: contratos sucessivos (contrato de fornecimento e contrato de locação), contratos de execução continuada ou periódica (ex.: contrato de trabalho), contratos de prestações repetidas. O que importa, afirma, "é deixar claro que o traço essencial desses contratos é a distribuição da execução no tempo". ${ }^{280}$

Assim, para que haja a possibilidade de revisão ou resolução dos contratos por alteração das circunstâncias é necessário que se esteja diante de contratos em que haja um período de tempo entre a sua celebração e o cumprimento da obrigação, em síntese, em contratos em que "há um intervalo de tempo razoável entre a sua celebração e a completa execução". ${ }^{281}$ Sobre isso, Fernandes Carvalho sustenta que "não há limite de tempo mínimo para a imprevisão funcionar", bastando que a execução do contrato se verifique "algum tempo depois da celebração dele para que possa sobrevir uma alteração de circunstâncias que justifique a aplicação da teoria". ${ }^{282}$

Ricardo Luis Lorenzetti discorre sobre como os efeitos do tempo podem atingir o equilíbrio de um contrato. Para tanto, invoca o exemplo do contrato de seguro de saúde o qual envolve muitas variáveis, pois, na sua gênese, o contrato é firmado conforme um determinado nível de qualidade, uma relação de médicos, um equipamento tecnológico específico, mediante o pagamento de um preço. Com o transcurso do tempo, que pode significar vários anos, o que era bom se torna antigo, surgem novas tecnologias, os médicos envelhecem, surgem outros mais especializados ou atualizados, as possibilidades de cura se incrementam, aparecem novas enfermidades, as expectativas do paciente se modificam, os custos aumentam, e o preço que se paga em contraprestação pode ser insuficiente. ${ }^{283}$

\footnotetext{
${ }^{279}$ GOMES, Orlando. Contratos. Rio de Janeiro: Forense, 2007. p. 94.

${ }^{280}$ Ibid., p. 95.

${ }^{281}$ GONÇALVES, Carlos Roberto. Direito Civil Brasileiro. v. III. 5. ed. São Paulo: Saraiva, 2008. p. 175.

${ }^{282}$ CARVALHO FERNANDES, Luís A. A teoria da imprevisão no Direito Civil português. Lisboa: Quid Juris?, 2001. p. 113.

${ }^{283}$ LORENZETTI, Ricardo. Tratado de los contratos. Tomo I. Buenos Aires: Rubinzal - Culzoni, 2004. p. 114.
} 
Este autor sintetiza: "son numerosas las circunstancias económicas que varían en un mundo donde imperan lo flexible, el aceleramiento de las innovaciones tecnológicas, las mudanzas en las expectativas de los contratantes y las sorprendentes caducidades de los bienes". 284

O desequilíbrio contratual decorrente de acontecimento posterior à sua celebração nos contratos de duração implicará a ausência de um "sinalagma funcional"285, não do genético, ou seja, a possibilidade de revisão/resolução do contrato em razão da alteração das circunstâncias não se dará, portanto, nos contratos de execução imediata. Havendo um desequilíbrio na gênese do contrato (ausência de sinalagma genético ${ }^{286}$ ) se poderá ver aplicado, por exemplo, o instituto da lesão ou do estado de perigo, o que acarretará a anulação do contrato, ou eventualmente a sua modificação para recuperação do equilíbrio, conforme dispõem os artigos 156 e 157 do Código Civil.

Sobre o instituto da lesão, Luiz Philipe Tavares de Azevedo Cardoso afirma:

A lesão consagrada no art. 157 do Código Civil é um dos defeitos do negócio jurídico. Tem como pressupostos um elemento objetivo, consistente na desproporção manifesta entre prestação e contraprestação, e um elemento subjetivo, referente à premente necessidade ou inexperiência da parte prejudicada. Ocorre no momento da formação da declaração negocial e sua sanção é a anulabilidade. A lesão, portanto, está ligada à ausência de equivalência no sinalagma genético, enquanto a onerosidade excessiva é uma perturbação no sinalagma funcional. A lesão exige que a vontade esteja fragilizada no momento da declaração, por conta da premente necessidade ou inexperiência - daí sua natureza de defeito do negócio jurídico - que não se cogita na onerosidade excessiva. ${ }^{287}$

Para Rogério Ferraz Donnini, nos contratos de execução imediata não teria sentido falar em fatos imprevisíveis que pudessem alterar o equilíbrio contratual ${ }^{288}$, mesmo porque “não há possibilidade do fato superveniente ocorrer e, conseqüentemente, não poderá haver

\footnotetext{
${ }^{284}$ LORENZETTI, Ricardo. Tratado de los contratos. Tomo I. Buenos Aires: Rubinzal - Culzoni, 2004. p. 115.

${ }^{285}$ No sinalagma funcional a dependência entre as prestações não se encontra no momento de seu nascimento, mas se refere à execução das obrigações bilaterais (REZZÓNICO, Juan Carlos. Principios fundamentales de los contratos. Buenos Aires: Astrea, 1999. p. 328).

${ }^{286}$ Alguns autores como Juan Carlos Rezzónico sustentam ainda a existência do chamado sinalagma condicional o qual depende da persistência de cada dever de prestação da existência da contraprestação, de maneira que, se a prestação convencionada por uma parte se frustra imediatamente à conclusão do contrato, conduzirá à liberação da parte contrária. (REZZÓNICO, Juan Carlos. Op. cit., p. 330).

${ }^{287}$ CARDOSO, Luiz Philipe Tavares de Azevedo. A onerosidade excessiva no Direito Civil Brasileiro. Dissertação (Mestrado) - Universidade de São Paulo, São Paulo, 2010. p. 89.

${ }^{288}$ DONNINI, Rogério Ferraz. A revisão dos contratos no Código Civil e no Código de Defesa do Consumidor. 2. ed. São Paulo: Saraiva, 2001. p. 64.
} 
excessiva onerosidade, entendida como desequilíbrio superveniente". ${ }^{289}$

Ainda, para a possibilidade de revisão de um contrato de duração, além de outros requisitos, conforme se observará na sequência, em regra, há necessidade que existam prestações pendentes de execução no todo ou em parte. Para corroborar esta afirmação, Ferraz Donnini invoca palavras de Luiz Diez Picazo: "Por regla general debe entenderse que la desaparición de la base del negocio afecta o incide sobre las prestaciones pendientes de ejecución, pero no sobre las prestaciones ya ejecutadas". ${ }^{290}$ Parece evidente, entretanto, que nesta hipótese a revisão do contrato levará em conta que uma parte das prestações foi cumprida sem gravames extraordinários. ${ }^{291}$

Embora reconheça que o entendimento majoritário seja no sentido de que a resolução ou modificação do contrato por onerosidade excessiva somente possa incidir sobre contratos que não se encontrem integralmente cumpridos, Mário Júlio de Almeida Costa admite que possam existir algumas exceções, nas quais, mesmo após a completa execução das prestações contratuais de uma ou de ambas as partes, seja justificável a resolução ou revisão do contrato, apontando o seguinte exemplo: “ $A$ celebra com uma empresa estrangeira, $B$, um contrato de aquisição de tecnologia industrial para o fabrico, no país, de certa especialidade farmacêutica; transmitida essa tecnologia e satisfeito o preço, ainda antes do início da laboração, a autoridade pública proíbe que se produza a venda, em todo o território nacional, do referido medicamento". 292

Este autor ainda coloca:

Importa, em síntese, que as circunstâncias determinantes para uma das partes se mostrem conhecidas ou cognoscíveis para a outra. E, ainda, que esta última, se lhe tivesse sido proposta a subordinação do negócio à verificação das circunstâncias pressupostas pelo lesado a aceitasse ou devesse aceitar, procedendo de boa fé. A resolução ou revisão pode, de resto, justificar-se, caso a boa fé a imponha ao tempo em que o problema se levanta, embora não já com referência à data da conclusão do negócio. ${ }^{293}$

Sobre o referido exemplo, Regina Beatriz Tavares da Silva Papa dos Santos observa que neste caso a teoria da imprevisão poderia ser aplicada com "grande senso de justiça, embora o contrato em questão já tivesse sido executado em sua totalidade por ambas as

289 CARDOSO, Luiz Philipe Tavares de Azevedo. A onerosidade excessiva no Direito Civil Brasileiro. Dissertação (Mestrado) - Universidade de São Paulo, São Paulo, 2010. 89.

${ }^{290}$ DONNINI, Rogério Ferraz. A revisão dos contratos no Código Civil e no Código de Defesa do Consumidor. 2. ed. São Paulo: Saraiva, 2001. p. 61.

${ }^{291}$ SACCO, Rodolfo; DE NOVA, Giorgio. II contrato. 3. ed. Torino: Editrice Torinese. Tomo Secondo, 2004. p. 715.

${ }^{292}$ COSTA, Mário Júlio de Almeida. Direito das obrigações. 9. ed. Coimbra: Almedina, 2003. p. 310-311.

293 Ibid., p. 303. 
partes". 294

Claudio Luiz Bueno de Godoy ${ }^{295}$ também questiona a afirmativa de que a imprevisão só tenha lugar em contratos ainda não findos ou cumpridos. Para tanto, invoca o posicionamento de Durval Ferreira, que por sua vez sustenta:

Desde logo, não se vê razoabilidade no pressuposto de que o contrato ainda não esteja executado, cumprido. Os célebres Coronation Cases, de 1901, em Inglaterra, têm-se configurado como da locação por A. de janela para o dia previsto do cortejo real que por doença súbita do Rei, se não veio a verificar. Mas para a mesma destinação poderia B ter comprado (por um alto preço, dado o previsto cortejo) uma vivenda e a pagar em 90 dias (após o dia previsto para o cortejo). Como igualmente poderia C. para a mesma destinação haver comprado (igualmente a alto preço) uma vivenda, dias antes do cortejo, que logo lhe foi entregue e logo pagou. Onde estaria a razoabilidade, de o negócio ser resolúvel para A. e B....e não o ser para C.?"296

Não é possível afirmar-se que para C. houve a incidência em erro, pois, neste vício de consentimento, a discrepância entre a declaração e a realidade é originária, isto é, se dá na formação do contrato, o que não acontece na hipótese. Isto porque no momento da celebração do contrato tudo levava a crer que o cortejo se realizaria. A mudança no estado de fato é superveniente à formação do vínculo. Havendo alteração das circunstâncias posterior à constituição do vínculo, é possível a resolução ou a modificação do contrato para que este atinja um equilíbrio, mas não é possível a anulação em decorrência de erro.

Nas palavras de Carvalho Fernandes ${ }^{297}$,

[...] não parece justo que não possa o credor exigir uma prestação que factos impossíveis de prever, independentes de culpa do devedor e sem qualquer mérito especial da parte daquele, vieram tornar muito onerosa para o devedor e insuspeitadamente rendosa para o credor. E o mesmo se diga se a alteração se processa em sentido inverso - tornar-se a prestação sem interesse para o credor, ainda que não ficasse mais fácil para o devedor.

É justamente nesta última hipótese aventada pelo autor que C., no exemplo há pouco citado, se encaixaria.

Para Carvalho Fernandes, o "contrato cessa se o fim principal tido em vista pelos

${ }^{294}$ SANTOS, Regina Beatriz Tavares da Silva Papa dos. Cláusula "Rebus Sic Stantibus" ou Teoria da Imprevisão. Revisão Contratual. Belém: CEJUP, 1989. p. 38.

${ }^{295}$ GODOY, Claudio Luiz Bueno de. A função social do contrato: os novos princípios contratuais. 3. ed. São Paulo: Saraiva, 2009. p. 67.

${ }^{296}$ FERREIRA, Durval. Erro negocial - objecto - motivos - base negocial e alterações de circunstâncias. Coimbra: Almedina, 1998. p. 116.

${ }^{297}$ CARVALHO FERNANDES, Luís A. A teoria da imprevisão no Direito Civil português. Lisboa: Quid Juris?, 2001. p. 14. 
contraentes deixa de existir". ${ }^{298}$ Pode-se afirmar que, na hipótese aventada, houve a frustração do fim do contrato, ou seja, houve a perda do sentido ou razão de ser do contrato. ${ }^{299} 300$

Considerando-se a relação obrigacional como um processo nos moldes já expostos, é possível afirmar-se que deve existir proporcionalidade entre o equilíbrio existente no momento da formação do contrato e o momento de sua execução. Nas palavras de Giuseppe Osti, é necessário que permaneça uma determinada relação de valor, interpretada como a "permanência do equilíbrio da utilidade em geral". 301

\subsubsection{Excessiva onerosidade na prestação para uma das partes}

O Código Civil exige ainda, no artigo 478, que a prestação se torne "excessivamente onerosa" para uma das partes, acarretando, portanto, um desequilíbrio contratual.

A onerosidade excessiva não se caracteriza por uma "simples dificuldade, mas sim uma situação que realmente colocará a parte em grande embaraço no cumprimento da prestação". ${ }^{302}$ Esta afirmação é a razoável, pois, se fosse possível rever contratos a toda e qualquer dificuldade no cumprimento da obrigação, a segurança dos negócios jurídicos estaria seriamente abalada.

Segundo a doutrina, para a possibilidade de aplicação do instituto, o desequilíbrio pode recair tanto na prestação quanto na contraprestação e deve ultrapassar a "álea normal do contrato" 303 . Com isto, verifica-se que também o credor terá legitimidade para tomar as medidas buscando a revisão ou resolução do contrato e, consequentemente, o equilíbrio contratual.

Inclusive, para Carvalho Fernandes ${ }^{304}$, as alterações são consideradas irrelevantes justamente quando estão compreendidas na álea normal do contrato, o que no direito

\footnotetext{
${ }^{298}$ CARVALHO FERNANDES, Luís A. A teoria da imprevisão no Direito Civil português. Lisboa: Quid Juris?, 2001. p. 25.

${ }^{299}$ ITURRASPE, Jorge Mosset; PIEDECASAS, Miguel A. La revisión del contrato. Santa Fe: Rubinzal Culzoni, 2008. p. 329.

${ }^{300}$ Sobre a frustração do fim do contrato, o § 265 do segundo Restatement of Contracts norte-americano prevê: Discharge by Supervening Frustration. Where, after a contract is made, a party's principal purpose is substantially frustrated without his fault by the occurrence of an event the non-occurrence of which was a basic assumption on which the contract was made, his remaining duties to render performance are discharged, unless the language or the circumstances indicate the contrary.

${ }^{301}$ OSTI, Giuseppe. Scritti Giuridici. Milano: Giuffrè, 1973. p. 267.

${ }^{302}$ SCHUNCK, Giuliana Bonanno. A onerosidade excessiva superveniente no Código Civil: críticas e questões controvertidas. São Paulo: LTR, 2010. p. 87.

${ }^{303}$ FRANTZ, Laura Coradini. Revisão dos contratos: elementos para sua construção dogmática. São Paulo: Saraiva, 2007. p. 114.

${ }^{304}$ CARVALHO FERNANDES, Luís A. Op. cit., p. 107.
} 
português encontra previsão expressa no artigo 437 o $^{305}$

Não será, portanto, qualquer alteração que implicará onerosidade excessiva, "Ela tem de ser suficiente para causar o desequilíbrio entre as partes no cumprimento das prestações a que se obrigaram [...] tem de ter magnitude e ser grande o suficiente para que ocorra desequilíbrio na prestação".306

É justamente a magnitude do desequilíbrio entre as prestações que merecerá apurada análise do magistrado diante do caso concreto, em uma análise que deverá ser feita objetivamente, "desconectada da situação subjetiva do devedor". 307

Alguns autores, entretanto, têm admitido uma análise subjetiva da onerosidade excessiva, como o fez, por exemplo, Antonio Junqueira de Azevedo, quando distinguiu os "contratos existenciais" dos "contratos empresariais". Os contratos existenciais seriam os contratos de consumo, os de trabalho, os de locação residencial, ou seja, aqueles que dizem respeito à subsistência da pessoa humana. Já os contratos empresariais seriam os contratos mantidos entre empresários, pessoas físicas ou jurídicas, ou, ainda, o contrato entre empresário e um não empresário que, porém, naquele contrato, visa obter lucro. De acordo com este autor, os contratos empresariais teriam um regime de menor interferência judicial; “neles, por exemplo, não caberia revisão judicial por questões de onerosidade excessiva subjetiva, - possível, porém, sob a idéia de função social, quando se trata de pessoa humana e contrato existencial". 308

Neste mesmo sentido é o posicionamento de Cláudia Lima Marques, para quem, nas relações consumeristas, é possível uma análise subjetiva como fundamento para a revisão contratual de forma que "circunstâncias subjetivas passivas, como a perda do emprego, acidentes, divórcios, entre outros, sejam causas possíveis do inadimplemento sem culpa". 309

A análise subjetiva deve ser feita com cautela

[...] de modo a não aniquilar a segurança jurídica e prejudicar a economia

${ }^{305}$ Art. $437^{\circ}$ Condições de admissibilidade.

1. Se as circunstâncias em que as partes fundaram a decisão de contratar tiverem sofrido uma alteração anormal, tem a parte lesada direito à resolução do contrato, ou à modificação dele segundo juízos de equidade, desde que a exigência das obrigações por ela assumidos afecte gravemente os princípios da boa fé e não esteja coberta pelos riscos próprios do contrato.

2. Requerida a resolução, a parte contrária pode opor-se ao pedido, declarando aceitar a modificação do contrato nos termos do número anterior.

${ }^{306}$ SANTOS, Antonio Jeová. Função Social: Lesão e Onerosidade Excessiva nos Contratos. São Paulo: Método, 2002. p. 241.

${ }^{307}$ FRANTZ, Laura Coradini. Revisão dos contratos: elementos para sua construção dogmática. São Paulo: Saraiva, 2007. p. 112.

${ }^{308}$ AZEVEDO, Antonio Junqueira de. Relatório brasileiro sobre a revisão contratual apresentado para as Jornadas Brasileiras da Associação Henri Capitant. In . Novos estudos e pareceres de direito privado. São Paulo: Saraiva, 2009, p. 184.

${ }^{309}$ MARQUES, Cláudia Lima. Contratos no Código de Defesa do Consumidor. São Paulo: RT, 2002. p. 248. 
com a intervenção judicial em contratos de forma desmedida [...] Isso não quer dizer, porém, que devemos rechaçar toda e qualquer hipótese de onerosidade subjetiva, mas devemos vê-las como exceções que não são abarcadas pela figura da onerosidade excessiva superveniente para os fins do Código Civil, podendo eventualmente ser resolvidas com base em outros institutos, tais como a função social, a boa-fé como forma de proteção ao consumidor etc. ${ }^{310}$

Otavio Luiz Rodrigues Júnior, por seu turno, afirma que a análise subjetiva na relação civil deve ser afastada. ${ }^{311}$

Manuel Miranda Canales, ao tratar da onerosidade excessiva, afirma que ela deve constituir um desequilíbrio grave na equivalência das prestações cuja desigualdade caberá ao julgador apreciar com "criterio razonable",312, ou ainda, segundo Carvalho Fernandes, "num prejuízo tal que exigir a execução da prestação seria cometer uma injustiça flagrante". 313

$\mathrm{O}$ equilíbrio contratual frequentemente é definido em função da equivalência das prestações, ou seja, "a equivalência entre o objeto recebido e a prestação fornecida". Entretanto, este critério seria insuficiente, primeiramente porque não poderia ser aplicado de "maneira realista", na medida em que, de acordo com Laura Coradini Frantz,

[...] divergiria da própria noção de contrato, pacto concluído a fim de se obter um ganho, o que seria contrário à própria noção de equivalência”. Em segundo lugar porque, mesmo que se considere a equivalência das prestações de forma relativa, poderá existir "um equilíbrio sem equivalência das prestações e uma equivalência sem equilíbrio do contrato. ${ }^{314}$

A referida autora, forte na lição de Laurence Fin-Langer, propõe quatro critérios para a definição do equilíbrio contratual: 1) reciprocidade de obrigações e de direitos: o desequilíbrio seria caracterizado pela ausência de reciprocidade no conteúdo do contrato, manifestada em sua execução; 2) comutatividade: relacionada à "noção de contrato comutativo, que é aquele no qual "cada uma das partes reconhece desde a conclusão do contrato, a importância das prestações recíprocas tidas por equivalentes"” ; 3 ) equivalência: caracterizada pela igualdade dos valores de troca de duas prestações correlativa, sendo que esta "igualdade" não seria meramente objetiva, pois dependeria de fenômenos subjetivos;

\footnotetext{
${ }^{310}$ SCHUNCK, Giuliana Bonanno. A onerosidade excessiva superveniente no Código Civil: críticas e questões controvertidas. São Paulo: LTR, 2010. p. 91.

311 RODRIGUES JÚNIOR. Otávio Luiz. Revisão judicial dos contratos. Autonomia da vontade e teoria da imprevisão. São Paulo: Atlas, 2006. p. 129.

${ }^{312}$ CANALES, Manuel Miranda. Derecho de los contratos Lima: Cultural Cuzco, 1988. p. 56.

${ }^{313}$ CARVALHO FERNANDES, Luís A. A teoria da imprevisão no Direito Civil português. Lisboa: Quid Juris?, 2001. p. 22.

${ }^{314}$ FRANTZ, Laura Coradini. Revisão dos contratos: elementos para sua construção dogmática. São Paulo: Saraiva, 2007. p. 115.
} 
"sendo baseada em valores individuais"; 4) proporcionalidade: através da decomposição de seus três elementos (adequação, necessidade e proporcionalidade em sentido estrito). ${ }^{315}$

Fernando Rodrigues Martins, entretanto, afirma que a justiça contratual, ou sua “expressão mais paralela quanto ao contrato (equilíbrio)", é concebida sob a perspectiva de sete postulados ou critérios que são comuns e informadores do modo de solução de situações injustas nas relações jurídicas contratuais, quais sejam: 1) a reciprocidade; 2) a comutatividade; 3) a equivalência material; 4) a proporcionalidade; 5) a proibição de enriquecimento sem causa; 6) a função social do contrato; 7) a distribuição de ônus e riscos. $^{316}$

A reciprocidade representaria uma "carga de correlação quanto às prestações assumidas no programa contratual entre as contrapartes conhecida como sinalagma”. Assim, haveria reciprocidade se a "determinada prestação assumida por uma parte corresponde uma contraprestação, a cargo da outra parte".317

A comutatividade seria um postulado relacionado às prestações pactuadas e estaria relacionada ao contrato comutativo que "é aquele que exige uma sociedade entre as partes com objetivo específico e ensejador de vantagens mútuas, ou melhor, de mútua conveniência de valor análogo das prestações", 318

Por intermédio do postulado da equivalência material busca-se a "igualdade dos valores e encargos nas prestações correlativas" e leva a uma "suficiente aproximação entre as prestações, quer na perspectiva de preço, quer na perspectiva de direitos e deveres entre as contrapartes". 319

O postulado da proporcionalidade, por sua vez, estaria relacionado não somente aos deveres de prestação (como, por exemplo, "para depurar os excessos havidos na formulação de preços referentes aos contratos de longa duração e que tenham por objeto o fornecimento de serviços" ${ }^{\text {,20 }}$ ), mas também à relação de causalidade entre um meio e um fim. Sob esta última vertente, o autor, forte no pensamento de Aldo Sandulli, afirma que o problema da

\footnotetext{
315 FRANTZ, Laura Coradini. Revisão dos contratos: elementos para sua construção dogmática. São Paulo: Saraiva, 2007. p. 118.

${ }^{316}$ MARTINS, Fernando Rodrigues. Princípio da justiça contratual. São Paulo: Saraiva, 2009. p. $269-273$.

317 Ibid., p. 273.

${ }^{318}$ Para Fernando Martins Rodrigues, a diferença entre a reciprocidade e a comutatividade está em que naqueles o princípio da justiça contratual é compreendido ante o esforço de ambas as contrapartes na realização do programa contratual (obrigações correspondentes), enquanto que na comutatividade a justiça contratual é perspectivada na atribuição das vantagens pensadas e destinadas a ambos os contratantes (MARTINS, Fernando Rodrigues. Princípio da justiça contratual. São Paulo: Saraiva, 2009. p. 276).

${ }^{319}$ Ibid., p. 278.

${ }^{320}$ Fernando Rodrigues Martins exemplifica com a hipótese de serviços pagos por consumidor, mas que não são prestados pelo fornecedor, "razão pela qual os Tribunais têm manifestado a importância de correção do preço do contrato pelo postulado da proporcionalidade" (MARTINS, Fernando Rodrigues. Op. cit., p. 284).
} 
proporcionalidade está no "exercício da justa medida do poder, de modo a esmiuçar uma ação idônea e adequada à circunstância de fato, que não alterem o justo equilíbrio entre valor, interesse, situação jurídica". ${ }^{321}$

O quinto postulado elencado por Fernando Rodrigues Martins consiste na proibição do enriquecimento sem causa como um critério prestacional. Segundo o autor, o referido postulado prepondera na

[...] iniciativa do ordenamento jurídico de criar um dever de restituição daquele que numa relação jurídica enriqueceu desprovido de quaisquer fundamentos, gerando, por determinado nexo de causalidade, o empobrecimento da contraparte. Nesse viés, a proibição do enriquecimento visa combater o deslocamento patrimonial (fluxo e refluxo de valores) sem justificação, o que leva à injustiça. ${ }^{322}$

A função social do contrato é elencada pelo autor como um sexto postulado da justiça contratual e consistiria: “(i) na exigência de solidarismo para o amparo da dignidade da pessoa humana nas avenças celebradas entre as partes; (ii) na investigação dos efeitos e efetividade do estipulado pelas partes ante determinado terceiro; (iii) na verificação de efeitos negativos perante a sociedade; (iv) solução do contrato por falta de fim". ${ }^{323}$

O último postulado estaria na distribuição de riscos e ônus em que a justiça do contrato seria informada pela "existência de dispositivos que atuam de forma a apontar aquele que deve suportar o dever de indenizar advindo de danos ou da inexecução espontânea do contrato". ${ }^{324}$ Este postulado refletiria um aspecto "qualitativo do dever de prestação, que deve pautar-se pelo equilíbrio entre as partes, ou, pelo menos, quando demonstrada a iniqüidade, seja corrigido ou revisto a bem do contrato". 325

Laura Coradini Frantz afirma que, não obstante os critérios por ela citados, tem-se entendido que, isoladamente, são insuficientes para "abranger todas as nuances que um contrato complexo oferece [...]. Os quatro critérios deverão ser aplicados de maneira coerente, adaptando-se às situações apresentadas pelos contratos na busca pelo equilíbrio contratual", 326

Importante também ressaltar que se admite a revisão ainda que a onerosidade seja temporária, sendo que, "proposta a ação, a sentença somente produzirá efeitos enquanto

\footnotetext{
${ }^{321}$ MARTINS, Fernando Rodrigues. Princípio da justiça contratual. São Paulo: Saraiva, 2009. p. 286.

322 Ibid., p. 288.

323 Ibid., p. 294.

${ }^{324}$ Ibid., p. 306.

325 Ibid., p. 317.

${ }^{326}$ FRANTZ, Laura Coradini. Revisão dos contratos: elementos para sua construção dogmática. São Paulo: Saraiva, 2007. p. 120.
} 
perdurar a excessiva onerosidade da prestação; ter-se-á, então, decisão judicial com eficácia subordinada à manutenção das circunstâncias levadas em consideração pelo julgador”. 327

\subsubsection{Acontecimentos extraordinários e imprevisíveis}

O legislador pátrio exigiu ainda, no já citado artigo 478 do Código Civil, que o desequilíbrio contratual decorra de "acontecimentos extraordinários e imprevisíveis".

O sentido de previsibilidade deve ser compreendido como "A razoável possibilidade de representação de um acontecimento incerto" ${ }^{328}$, sendo que não é possível afirmar-se que todo evento extraordinário seja imprevisível. ${ }^{329}$

O evento que torne a prestação excessivamente onerosa deve fugir à álea normal do contrato. Seria, imprevisível, portanto,

[...] aquilo que não pode ser "legitimamente esperado pelas partes, de acordo com a sua justa expectativa", o que deve ser analisado no momento da conclusão do contrato, por intermédio de um juízo de fato, pois os graus de certeza e de especificidade de determinado evento não podem ser indicados por uma simples definição jurídica. ${ }^{330}$

Enzo Roppo, por sua vez ensina:

[...] a excessiva onerosidade superveniente deve depender de acontecimentos extraordinários e imprevisíveis. E compreende-se: se as circunstâncias que a determinam pertencem ao ordinário curso dos acontecimentos naturais, políticos, econômicos ou sociais, e podiam, por isso, ter sido previstas aquando da conclusão do negócio, não há razão para tutelar o contraente que nem sequer usou da normal prudência necessária para representar-se a possibilidade da sua ocorrência e regular-se de acordo com as mesmas na determinação do conteúdo contratual. É justo e racional que o risco das circunstâncias ordinárias e previsíveis seja suportado pelos contraentes: a lei só protege contra as circunstâncias que representam matéria de riscos absolutamente anômalos, como tais subtraídos à possibilidade de razoável previsão e controlo dos operadores. ${ }^{331}$

Este evento extraordinário e imprevisível deve ser posterior à celebração do contrato

\footnotetext{
327 AZEVEDO, Antonio Junqueira de. Relatório brasileiro sobre a revisão contratual apresentado para as Jornadas Brasileiras da Associação Henri Capitant. In Novos estudos e pareceres de direito privado. São Paulo: Saraiva, 2009, p. 193.

${ }^{328}$ Em demanda revisional, o Tribunal de Justiça do Estado de São Paulo decidiu que empresa que atua no segmento de abastecimento de água não "poderia ignorar a tendência de escassez desse produto" (Apelação Cível n. 557.099.4/2-00, $3^{\text {a }}$ Câmara de Direito Privado, Rel. Donegá Morandini, j. 19.05.2009).

${ }^{329}$ FRANTZ, Laura Coradini. Op. cit., p. 123.

${ }^{330}$ Ibid., p. 127.

${ }^{331}$ ROPPO, Enzo. Coimbra: Almedina, 1977. p. 261-262.
} 
e anterior à sua execução. Sendo um evento preexistente à celebração do contrato, é evidente que não se pode falar em desequilíbrio superveniente. Nesta hipótese, conforme já afirmado, pode configurar-se uma falta de sinalagma genético, quando então, estar-se-á diante da lesão ou do estado de perigo.

Sobre o conceito de imprevisibilidade, Ruy Rosado de Aguiar Júnior afirma:

É provável o acontecimento futuro que, presentes as circunstâncias conhecidas, ocorrerá, certamente, conforme o juízo derivado da experiência. Não basta que os fatos sejam possíveis (a guerra, a crise econômica sempre são possíveis), nem mesmo certos (a morte). É preciso que haja notável probabilidade de que um fato, com seus elementos, atuará eficientemente sobre o contrato, devendo o conhecimento das partes incidir sobre os elementos essenciais desse fato e da sua força de atuação sobre o contrato. (...) A probabilidade, para ter relevância jurídica, deve ter um certo grau (notável probabilidade), porque o conhecimento deve abranger os elementos essenciais do fato futuro causador da onerosidade e a força de seus efeitos sobre o contrato. ${ }^{332}$

Para Judith Martins-Costa, a imprevisibilidade deve ser relativizada "para considerar-se a expressão em seu significado normativo, de correspondência à legítima expectativa das partes no momento da conclusão do ajuste, tendo-se em conta, como fato primordial, o objetivo desequilíbrio não-imputável à parte prejudicada". 333

A doutrina italiana admite ainda a invocação da onerosidade excessiva da prestação quando o fato em si, gerador da desproporção, já era conhecido das partes contratantes (como, por exemplo, contratar durante o desenrolar de uma guerra), mas a amplitude dos efeitos gerados pelo evento previsível não podia ser legitimamente esperada por elas. ${ }^{334}$

Entretanto, a redação do artigo 478 vem recebendo críticas.

Nelson Borges, por exemplo, afirma que o artigo padece de uma linguagem sem apuro técnico, apresentando uma redundância inadmissível quando fala em "acontecimentos extraordinários e imprevisíveis":

É elementar que imprevisivel é aquele fato que se situa além das fronteiras em que se desenrolam os acontecimentos normais, comuns, ordinários portanto, fora de qualquer previsão possível. Aos buscarmos o conceito de extraordinário, até etimologicamente temos que aceitar como tudo aquilo que gravita fora da órbita do que é ordinário - portanto, imprevisível. Então,

\footnotetext{
332 AGUIAR JÚNIOR, Ruy Rosado. Extinção dos contratos por incumprimento do devedor. Rio de Janeiro: AIDE, 2003. p. 155-156.

${ }^{333}$ MARTINS-COSTA, Judith. Comentários ao novo Código Civil. São Paulo: Saraiva, vol. 5, t. 1, 2003. p. 256257.

${ }^{334}$ FRANTZ, Laura Coradini. Revisão dos contratos: elementos para sua construção dogmática. São Paulo: Saraiva, 2007. p. 130.
} 
se acontecimento imprevisível significa não-previsível, não ordinário, incomum, extraordinário, não há como fugir à evidência gritante de que extraordinário quer dizer não-ordinário, não-previsível, incomum portanto, imprevisível. Donde a equivalência dos termos e sua conseqüente redundância. Inaceitável, sob todos os aspectos. Em nome de elementar tecnicidade, urge sua reformulação.". 335

Há autores, entretanto, que entendem haver diferença entre os conceitos de imprevisibilidade e de extraordinariedade,

[...] caracterizando-se a primeira por um "juízo subjetivo e relativo", e a segunda, por um "juízo objetivo". Portanto, a previsibilidade de um evento se mede pela capacidade de previsão do contratante médio (atualmente se busca a noção de contratante concreto, e não do homem médio abstratamente considerado) em determinado tipo contratual e em determinado setor do mercado em que o contrato se insere. ${ }^{336}$

Ruy Rosado de Aguiar Júnior flexibiliza o requisito da imprevisibilidade, considerando necessário para a revisão do contrato apenas o "dado objetivo da equivalência da prestação", não sendo necessário que a desproporção decorra de "motivos imprevisíveis". 337

Judith Martins-Costa também corrobora este posicionamento afirmando que a imprevisibilidade deve "ser relativizada, para considerar-se a expressão em seu significado normativo, de correspondência à legítima expectativa das partes no momento da conclusão do ajuste, tendo-se em conta, como fato primordial, o objetivo desequilíbrio não-imputável à parte prejudicada". 338

No mesmo sentido é o posicionamento de Giuliana Bonanno Schunck, para quem teria sido mais benéfico que o Código Civil exigisse apenas a alteração nas circunstâncias, nos moldes do disposto no artigo 437 do Código Civil português, sem mencionar que esta alteração seja decorrente de fatos imprevisíveis. ${ }^{339}$

Otavio Luiz Rodrigues Júnior também afirma que "o que importa realmente é saber se ocorreram alterações circunstanciais e se essas, mesmo com o cálculo, a cautela e a

\footnotetext{
${ }^{335}$ BORGES, Nelson. A teoria da imprevisão no Direito Civil e no Processo Civil. São Paulo: Malheiros, 2002. 675.

${ }^{336}$ FRANTZ, Laura Coradini. Revisão dos contratos: elementos para sua construção dogmática. São Paulo: Saraiva, 2007. p. 77.

${ }^{337}$ AGUIAR JÚNIOR, Ruy Rosado. Extinção dos contratos por incumprimento do devedor. Rio de Janeiro: AIDE, 2003. p. 152.

${ }^{338}$ MARTINS-COSTA, Judith. Comentários ao Novo Código Civil. São Paulo: Saraiva, vol. 5, t. 1, 2003, p. 256-257.

${ }^{339}$ SCHUNCK, Giuliana Bonanno. A onerosidade excessiva superveniente no Código Civil: críticas e questões controvertidas. São Paulo: LTR, 2010. p. 95.
} 
prudência, ensejam a mudança significativa na equação econômica do pacto, que se exterioriza especialmente pela excessiva onerosidade". 340

Também o BGB alemão, em seu já referido § 313, não faz qualquer menção à imprevisibilidade.

Orlando Gomes ensina que "fatos genericamente previsíveis podem ser imprevisíveis, quando tomados em sua especificidade e concretude. Em outras palavras, fatos genericamente previsíveis (como guerras ou mesmo a inflação) podem provocar efeitos concretos imprevisiveis". ${ }^{341}$

Sobre o tema, Luiz Philipe Tavares de Azevedo Cardoso afirma que a imprevisibilidade compreende "não só o fato em si (que pode até ser previsível), mas também seus efeitos (estes sim imprevisíveis)". 342

No mesmo sentido é o posicionamento de Claudio Luiz Bueno de Godoy, ao afirmar que a imprevisibilidade deve ser apreciada de forma extensiva, para que se possa considerá-la "atinente nem sempre ao fato em si, mas também à sua extensão, como no caso da inflação, de regra previsível ${ }^{343}$, embora não necessariamente na medida havida em dado momento histórico e econômico". ${ }^{344} \mathrm{O}$ problema seria, portanto, de quantidade e não de qualidade. ${ }^{345}$

Corroborando este posicionamento, afirma ainda Giuliana Bonanno Schunck: "Dessa forma, bastam que as conseqüências de determinado evento sejam imprevisíveis ou extraordinárias para que possa ser pleiteada a revisão do contrato pela parte prejudicada". ${ }^{346}$

Junqueira de Azevedo, por seu turno, assevera que fatos genericamente previsíveis podem provocar efeitos concretos imprevisíveis. Neste sentido, foi editado o Enunciado n. 17, aprovado na Jornada de Direito Civil do Centro de Estudos Judiciários de 2002, o qual,

\footnotetext{
${ }^{340}$ RODRIGUES JÚNIOR. Otávio Luiz. Revisão judicial dos contratos. Autonomia da vontade e teoria da imprevisão. São Paulo: Atlas, 2006. p. 160.

${ }^{341}$ GOMES, Orlando. Contratos. Rio de Janeiro: Forense, 2007. p. 215.

${ }^{342}$ CARDOSO, Luiz Philipe Tavares de Azevedo. A onerosidade excessiva no Direito Civil Brasileiro. Dissertação (Mestrado) - Universidade de São Paulo, São Paulo, 2010. p. 123.

${ }^{343}$ Neste sentido, o Tribunal de Justiça do Estado de São Paulo julgou improcedente revisional de contrato de financiamento imobiliário afirmando: "Não se fale em lesão ou desequilíbrio econômico, pois os apelantes não demonstraram a ocorrência de eventos imprevisíveis e extraordinários que tornassem o cumprimento de prestação exageradamente onerosa. Em verdade, tanto a inflação, como as alterações econômicas são fenômenos considerados absolutamente previsíveis entre os brasileiros e, porque não dizer, nas economias ocidentais, principalmente entre os chamados emergentes, entre os quais se inclui o Brasil" (Apelação Cível n. 9162145-11.2004.8.26.0000. Órgão julgador: 12a Câmara Cível do Tribunal de Justiça do Estado de São Paulo, j. 24.08.2011, Rel. Castro Figliolia).

${ }^{344}$ GODOY, Claudio Luiz Bueno de. A função social do contrato: os novos princípios contratuais.3. ed. São Paulo: Saraiva, 2009. p. 69.

${ }^{345}$ CARVALHO FERNANDES, Luís A. A teoria da imprevisão no Direito Civil português. Lisboa: Quid Juris?, 2001. p. 122.

${ }^{346}$ SCHUNCK, Giuliana Bonanno. A onerosidade excessiva superveniente no Código Civil: críticas e questões controvertidas. São Paulo: LTR, 2010. p. 96.
} 
reportando-se ao artigo 317 do Código Civil prevê: "A interpretação da expressão 'motivos imprevisíveis' constante no artigo 317 no Código Civil deve abarcar tanto causas de desproporção não previsíveis quando causas previsíveis, mas de resultados imprevisíveis". 347

Mais uma vez, menciona-se o Projeto de Lei n. 276/2007 348 , que objetiva alterar a redação do artigo 478 para excluir o requisito da imprevisibilidade, ressaltando-se ainda a existência do Enunciado n. 175 da III Jornada de Direito Civil do Centro de Estudos Judiciários do Conselho da Justiça Federal sobre o tema: “A menção à imprevisibilidade e à extraordinariedade, insertas no artigo 478 do Código Civil, deve ser interpretada não somente em relação ao fato que gere o desequilíbrio, mas também em relação às consequiências que ele produz".

Também o Projeto de Lei n. 3.619/2008 ${ }^{349}$ de autoria do Deputado Carlos Bezerra visa excluir do texto o termo "imprevisível" da redação do artigo 478.

\subsubsection{Extrema vantagem para a outra parte}

O artigo 478 do Código Civil exigiu também que a onerosidade excessiva trouxesse "extrema vantagem para a outra parte".

Este artigo exigiria, por exemplo, que,

${ }^{347}$ AZEVEDO, Antonio Junqueira de. Relatório brasileiro sobre a revisão contratual apresentado para as Jornadas Brasileiras da Associação Henri Capitant. In . Novos estudos e pareceres de direito privado. São Paulo: Saraiva, 2009, p. 209.

${ }^{348}$ Redação proposta: "Nos contratos de execução sucessiva ou diferida, tornando-se desproporcionais ou excessivamente onerosas suas prestações em decorrência de acontecimento extraordinário e estranho aos contratantes à época da celebração contratual, pode a parte prejudicada demandar a revisão contratual, desde que a desproporção ou a onerosidade exceda os riscos normais do contrato.

$\S 1^{\circ}$ Nada impede que a parte deduza, em juízo, pedidos cumulados, na forma alternativa, possibilitando, assim, exame judicial do que venha a ser mais justo para o caso concreto.

$\S 2^{\circ}$ Não pode requerer a revisão do contrato quem se encontrar em mora no momento da alteração das circunstâncias.

$\S 3^{\circ}$ Os efeitos da revisão contratual não se estendem às prestações satisfeitas, mas somente às ainda devidas, resguardados os direitos adquiridos por terceiros". (Disponível em $<$ http://www.camara.gov.br $>$. Acesso em: 14 jan. 2013)

${ }^{349}$ Na justificação para a elaboração do referido projeto, afirmou o Deputado Carlos Bezerra: "A teoria que fundamenta a revisão contratual é denominada "rebus sic stantibus" e preconiza a revisão contratual sempre que acontecimentos extraordinários e imprevisíveis violarem o equilíbrio entre as partes conforme já mencionado; representa exceção ao princípio, aliás não absoluto, de acordo com orientações doutrinárias mais recentes, de que o contrato faz leis entre as partes. Aliás, as modernas doutrinas sobre contratos ressaltam a sua função social, baseados nos princípios da boa-fé e probidade das partes, princípios que o tornam coerente e compatível com a realidade do bem estar coletivo. E dentro dessa ótica é decorrência lógica que a leitura, o cumprimento das avenças devem estar alicerçadas em escritos e avaliação que vedem onerosidade excessiva para uma das partes e enriquecimento indevido para a outra; esse entendimento é o que melhor atende ao princípio da solidariedade e dignidade da pessoa humana, agasalhado pela Constituição. Desnecessário, pois, que o fator de desequilíbrio, ocorrente durante o cumprimento do contrato, seja previsível ou não. Tem-se pois, que ocorrido um evento extraordinário que torne insuportável a contraprestação, impõe-se a revisão contratual". (Disponível em <http://www.camara.gov.br>. Acesso em: 14 jan. 2013). 
[...] num contrato de fornecimento, o facto de o credor do fornecimento, a manter-se inalterada a sua execução, poder continuar a receber os produtos ao preço antigo, enquanto que agora teria de pagar mais pela sua aquisição, não significa que daí lhe advenha um ganho. É que uma das razões que o levou a celebrar um contrato daquele tipo, ou a aceitar determinadas regras para o fornecimento, pode justamente ter sido a de garantir certa estabilidade ou regularidade na obtenção dos produtos em causa, com base nos quais ele firmou, por seu turno, por exemplo, condições de venda de bens com eles manufacturados, que tem de manter. ${ }^{350}$

Esta exigência vem, portanto, recebendo inúmeras críticas da doutrina, pois é possível que a onerosidade excessiva para uma das partes não implique, necessariamente, uma vantagem ou benefício para a outra, de forma que, uma análise simplista do contido no referido artigo poderia levar à conclusão de que se a onerosidade excessiva para uma parte não implicou em um benefício para a outra, o artigo 478 não poderia ser invocado.

Nesse sentido é o posicionamento de Ruy Rosado de Aguiar Júnior ao afirmar que "é possível que o fato futuro se abata sobre o devedor sem que daí decorra maior vantagem para o credor, e nem por isso deixa de existir a onerosidade excessiva que justifica a extinção ou a modificação do contrato por iniciativa do devedor". 351

Também Claudio Luiz Bueno de Godoy critica esta exigência a que denomina de efeito "gangorra".

[...] pela letra da nova lei, uma parte pode ser completamente reduzida à insolvência, por alteração das circunstâncias, sem acesso à teoria da imprevisão, se não comprovar lucro exorbitante da outra. E veja-se que se essa vantagem à outra parte pode até ser considerada de ocorrência normal, como contrapartida da onerosidade excessiva do devedor, nem sempre isso poderá suceder (lembre-se do exemplo do leasing em dólar, quando o banco brasileiro ainda deva o repasse ao banco estrangeiro). ${ }^{352}$

Sobre esta exigência, Antonio Celso Fonseca Pugliese faz sua crítica, afirmando que ela não se coaduna com o posicionamento dos principais ordenamentos jurídicos do mundo, implicando em mais um ônus processual para a parte prejudicada que terá ainda que provar a

\footnotetext{
${ }^{350}$ CARVALHO FERNANDES, Luís A. A teoria da imprevisão no Direito Civil português. Lisboa: Quid Juris?, 2001. p. 289.

${ }^{351}$ AGUIAR JÚNIOR, Ruy Rosado. Extinção dos contratos por incumprimento do devedor. Rio de Janeiro: AIDE, 2003. p. 28.

352 GODOY, Claudio Luiz Bueno de. A função social do contrato: os novos princípios contratuais. 3. ed. São Paulo: Saraiva, 2009. p. 67.
} 
vantagem da parte contrária. ${ }^{353}$

Regina Beatriz Tavares da Silva Papa dos Santos também se posiciona neste sentido:

\begin{abstract}
Alguns autores acreditam que deva ocorrer também o enriquecimento indevido para a outra parte, favorecida pelo desequilíbrio contratual, do que se ousa discordar, pois, casos há em que a onerosidade excessiva para uma das partes não implica em lucro excessivo para a outra, mas sim, até em algum prejuízo, por sofrer também as conseqüências da alteração das circunstâncias e, além disso, a finalidade principal da imprevisão é socorrer o contratante que será lesado pelo desequilíbrio contratual e não punir a parte que se enriquecerá com esse desequilíbrio. ${ }^{354}$
\end{abstract}

O que importa, na verdade, é o restabelecimento do equilíbrio contratual.

O já mencionado Projeto de Lei n. 276/2007, alterando a redação do artigo 478, não exige a vantagem da outra parte, sendo que na justificativa para o projeto foi consignado que "não se deve configurar a onerosidade excessiva, na dependência do contraponto de um grau de extrema vantagem. Isto significaria atenuar o instituto, sopesado por uma compreensão menor".

Também o Enunciado n. 365 da III Jornada de Direito Civil do Centro de Estudos Judiciários do Conselho da Justiça Federal prevê: "A extrema vantagem do artigo 478 deve ser interpretada como elemento acidental da alteração de circunstâncias, que comporta a incidência da resolução ou revisão do negócio por onerosidade excessiva, independentemente de sua demonstração plena".

O Código Civil italiano, no já mencionado artigo 1467, não exige o benefício ou vantagem da outra parte. Também a doutrina portuguesa entende não ser necessário que ao prejuízo de um dos contraentes corresponda um ganho do outro e muito menos um ganho equivalente. ${ }^{355}$

\title{
5.2 REQUISITOS NEGATIVOS
}

Algumas circunstâncias são impeditivas da revisão/resolução do pacto por alteração da conjuntura contratual. Sobre elas, passa-se a discorrer.

\footnotetext{
${ }^{353}$ PUGLIESE, Antonio Celso Fonseca. Teoria da imprevisão e o novo Código Civil. Revista dos Tribunais, São Paulo, v. 93, n. 830, p. 15-16, dez. 2004.

354 SANTOS, Regina Beatriz Tavares da Silva Papa dos. Cláusula 'Rebus Sic Stantibus" ou Teoria da Imprevisão. Revisão Contratual. Belém: CEJUP, 1989. p. 37.

${ }^{355}$ CARVALHO FERNANDES, Luís A. A teoria da imprevisão no Direito Civil português. Lisboa: Quid Juris?, 2001. p. 289.
} 


\subsubsection{Risco inerente ao contrato}

Para a doutrina majoritária, impedirá a revisão por onerosidade excessiva o desequilíbrio decorrente de um risco normal, ou seja, o risco inerente ao contrato, pois este deve ser esperado pelas partes.

É considerado um pressuposto ideológico e também uma regra do sistema o princípio de que à liberdade contratual está ligada a obrigação de respeito aos compromissos contratuais assumidos, e, portanto, “a assunção do risco relativo à possibilidade de a operação, de que se esperavam lucros, causar, ao invés, prejuízos". 356

Assim, Enzo Roppo afirma que "É justo e racional que o risco das circunstâncias ordinárias e previsíveis seja suportado pelos contraentes: a lei só os protege contra as circunstâncias que representam matéria de riscos absolutamente anómalos, como tais subtraídos à possibilidade de razoável previsão e controlo dos operadores". 357

\section{Segundo Laura Coradini Frantz}

[...] por álea normal ou risco se entende a órbita dentro da qual se verificam as oscilações de valor causadas por flutuações normais do mercado, compreende-se que não se pode falar de risco normal em sentido abstrato, uma vez que deverá ser deduzido da interpretação do contrato, indagando-se até que ponto as partes podem sofrer as consequiências de tais variações. Assim, por exemplo: nem sempre um contrato celebrado durante a guerra poderá ter esse fator inserido dentro do risco normal do contrato, dentro das flutuações do valor da prestação por ela provocadas, devendo ser analisado, em concreto, se tais flutuações foram consideradas pelas partes dentro do risco normal, considerando sempre a pessoa concreta, e as vicissitudes do tempo em que vive. ${ }^{358}$

Esta autora sintetiza, ainda, afirmando que risco normal "é uma noção econômica pela qual se deve entender a regular mutação de valor que a prestação pode sofrer, dada sua natureza e o tipo de relação a que pertence". 359

A álea normal do contrato, segundo Roppo, não pode ser identificada de modo geral e abstrato para todo o tipo de relação contratual, mas que "varia em relação aos particulares tipos de negócio, aos particulares mercados, às particulares conjunturas econômicas". 360

Nesse sentido, foi editado um Enunciado na IV Jornada de Direito Civil (Enunciado

\footnotetext{
${ }^{356}$ ROPPO, Enzo. O contrato. Coimbra: Almedina, 1977. p. 259.

357 Ibid., p. 259.

358 FRANTZ, Laura Coradini. Revisão dos contratos: elementos para sua construção dogmática. São Paulo: Saraiva, 2007. p. 75.

${ }^{359}$ Loc. cit.

${ }^{360}$ ROPPO, Enzo. Op. cit., p. 262-263.
} 
366), o qual prevê: "O fato extraordinário e imprevisível causador de onerosidade excessiva é aquele que não está coberto objetivamente pelos riscos próprios da contratação".

Carvalho Fernandes é elucidativo quanto ao tema ao afirmar

[...] há de ter-se presente que cada contrato, sobretudo quando a sua execução se prolonga no tempo, envolve certa margem de risco (própria do seu tipo), de ganho ou de perda; por assim ser, nenhum dos contraentes pode ignorar que a sua celebração comporta consequências dessa ordem, correspondentemente, tem de suportar. Esse risco cobre, por conseguinte, certas flutuações emergentes de eventos supervenientes, ou seja, por outras palavras, põe a cargo de um dos contraentes determinadas contingências de maior ou menor ganho ou perda. ${ }^{361} 362$

É importante a análise dos riscos contratuais que cada parte assumiu, ressaltando-se que estes riscos podem ser negociados por elas. Por vezes, o próprio negócio jurídico praticado é indicativo da assunção ou não destes riscos, e em outras ocasiões, demanda-se uma atividade interpretativa para determinar quem, no próprio contrato, havia assumido este ou aquele risco. Segundo Luz M. Martínez Velencoso, a previsibilidade dos riscos deve ser valorada em relação ao tipo de contrato celebrado e a quantidade de informação a que têm acesso as partes contratantes. ${ }^{363}$

Iturraspe e Piedcasas, por seu turno, afirmam que os riscos previsíveis podem ser

${ }^{361}$ CARVALHO FERNANDES, Luís A. A teoria da imprevisão no Direito Civil português. Lisboa: Quid Juris?, 2001. p. 268.

${ }^{362}$ Relativamente aos chamados "riscos normais do contrato", o Superior Tribunal de Justiça manifestou-se em pleito de resolução contratual por onerosidade excessiva: "DIREITO CIVIL E PROCESSUAL CIVIL. RECURSO ESPECIAL. OMISSÃO. INEXISTÊNCIA. CONTRATO DE COMPRA E VENDA DE SAFRA FUTURA DE SOJA. CONTRATO QUE TAMBÉM TRAZ BENEFÍCIO AO AGRICULTOR. FERRUGEM ASIÁTICA. DOENÇA QUE ACOMETE AS LAVOURAS DE SOJA DO BRASIL DESDE 2001, PASSÍVEL DE CONTROLE PELO AGRICULTOR. RESOLUÇÃO DO CONTRATO POR ONEROSIDADE EXCESSIVA. IMPOSSIBILIDADE. OSCILAÇÃO DE PREÇO DA "COMMODITY". PREVISIBILIDADE NO PANORAMA CONTRATUAL. 1. A prévia fixação de preço da soja em contrato de compra e venda futura, ainda que com emissão de cédula de produto rural, traz também benefícios ao agricultor, ficando a salvo de oscilações excessivas de preço, garantindo o lucro e resguardando-se, com considerável segurança, quanto ao cumprimento de despesas referentes aos custos de produção, investimentos ou financiamentos. 2. A "ferrugem asiática" na lavoura não é fato extraordinário e imprevisível, visto que, embora reduza a produtividade, é doença que atinge as plantações de soja no Brasil desde 2001, não havendo perspectiva de erradicação a médio prazo, mas sendo possível o seu controle pelo agricultor. Precedentes. 3. A resolução contratual pela onerosidade excessiva reclama superveniência de evento extraordinário, impossível às partes antever, não sendo suficiente alterações que se inserem nos riscos ordinários. Precedentes. 4. Recurso especial parcialmente provido para restabelecer a sentença de improcedência. (Recurso Especial n. 945.166-GO, Rel. Ministro Luis Felipe Salomão, $4^{a}$ Turma, j. 28.02.2012).

Em outro acórdão, o mesmo Tribunal decidiu: "CIVIL. CONTRATO. COMPRA E VENDA. SOJA. PREÇO FIXO. ENTREGA FUTURA. OSCILAÇÃO DO MERCADO. RESOLUÇÃO. ONEROSIDADE EXCESSIVA. BOA-FÉ OBJETIVA. CÉDULA DE PRODUTO RURAL. NULIDADE. - Nos contratos agrícolas de venda para entrega futura, o risco é inerente ao negócio. Nele não se cogita em imprevisão". (Recurso Especial n. 866414-GO, Rel. Ministro Humberto Gomes de Barros, $3^{\text {a }}$ Turma, j. 06.03.2008).

${ }^{363}$ MARTÍNEZ VELENCOSO, Luz M. Riesgo negocial v. cláusula "rebus sic stantibus". Barcelona: Revista para el Análisis Del Derecho. Enero 2011. http://ssrn.com/abstract= 1762779. Acesso em: 24 abr. 2012. 
adjudicados pelas partes, colocando-os a cargo desta ou daquela, mas que não podem fazê-lo com relação aos riscos imprevisíveis, não antecipáveis ainda que sob um olhar sagaz e atento. O imprevisível, segundo os autores, ao menos como regra, não pode ser acordado, e os riscos podem ser adjudicados por uma norma legal, ou atribuídos pelas partes no contrato. Havendo silêncio da lei e do contrato, alguns critérios tradicionais são invocados para a solução do problema: os riscos sobre a coisa são suportados pelo proprietário; suporta o risco quem o criou; assume o risco aquele que poderia prevê-lo etc. ${ }^{364}$

Nesse sentido, há uma proposta de modernização do direito espanhol que prevê no artigo 1.213 a alteração das circunstâncias "atendidas as circunstâncias do caso e especialmente a distribuição contratual ou legal dos riscos".

Nathan Somogie, contrariando o posicionamento de Iturraspe e Piedecasas, afirma que, se o evento superveniente que causa desequilíbrio for razoavelmente imprevisível quando da celebração do contrato, não se espera que a parte prejudicada tenha assumido os riscos da sua ocorrência. Entretanto, segundo o autor, o inverso não ocorre da mesma forma. Ou seja, embora a parte tenha falhado em incluir uma determinada cláusula contratual com relação a um risco previsível e isto sugira que ela o assumiu, outros fatores, tal como o histórico das negociações podem indicar o contrário. ${ }^{365}$

\subsubsection{Mora da parte}

Para que aquele que vê a sua prestação excessivamente onerosa em razão da alteração das circunstâncias possa invocar a resolução do contrato ou a sua modificação, em regra, não poderá encontrar-se em estado moroso, exercendo a sua pretensão antes do vencimento da obrigação contratada.

Exemplificando-se a hipótese, Carvalho Fernandes ${ }^{366}$ afirma:

Num contrato de fornecimento celebrado entre $A$ e $B$, este ficou obrigado a entregar determinados bens, a preço fixo, em certa data; $B$ não cumpriu atempadamente o contrato e, após se ter constituído em mora, deu-se um grande agravamento do custo dos bens a fornecer, afectou profundamente $\mathrm{o}$ equilíbrio antes verificado entre o seu custo e o preço a pagar por $A$.

Por força do art. $^{\circ} 438 .^{{ }^{3} 67}, \boldsymbol{B}$ tem de cumprir nos termos estipulados, não

\footnotetext{
${ }^{364}$ ITURRASPE, Jorge Mosset; PIEDECASAS, Miguel A. La revisión del contrato. Santa Fe: Rubinzal Culzoni, 2008. p. 29-32.

365 SOMOGIE, Nathan. Failure of a "Basic Assumption": The Emerging Standard for Excuse under MAE Provisions. Disponível em: < http:/ssrn.com/abstract=1448916>. Acesso em 24.04.2012.

${ }^{366}$ CARVALHO FERNANDES, Luís A. A teoria da imprevisão no Direito Civil português. Lisboa: Quid Juris?, 2001. p. 292.
} 
tendo o direito de resolver ou de modificar o contrato com fundamento na alteração das circunstâncias ocorrida após a sua mora.

Quando a alteração da base negocial tiver ocorrido antes do estado moratório, a pretensão poderá ainda ser exercida. ${ }^{368} \mathrm{Cabe}$, portanto, "distinguir a mora que antecede a alteração das circunstâncias da que lhe é superveniente". Conforme observa Regina Beatriz Tavares Papa dos Santos, que complementa:

\begin{abstract}
Assim, se a parte já estiver incursa nas sanções por inadimplemento quando o contrato é atingido pelo acontecimento turbador, não poderá ser socorrida pela noção da imprevisão; e caso as circunstâncias alteradoras do equilíbrio contratual precedam o retardamento no cumprimento das obrigações, sendo este atraso inimputável ao contratante, ele poderá ser acolhido pela revisão ou resolução de suas prestações. ${ }^{369}$
\end{abstract}

Sobre o tema, Enzo Roppo ${ }^{370}$ afirma:

[...] a resolução por excessiva onerosidade não pode ser invocada pelo contraente que se encontrava em mora (por ter atrasado o cumprimento para além do devido) no momento em que aquela se manifestou. É uma consequência do princípio geral, segundo o qual o devedor em mora suporta todos os riscos que se concretizam no período da mora.

Claudio Luiz Bueno de Godoy ensina que não se deve confundir a mora já configurada quando acontece o fato extraordinário, que afastaria a imprevisão, com a situação da prestação descumprida, mas por causa da onerosidade excessiva, vindo, logo a seguir a ser proposta a demanda de resolução ou revisão do ajuste. E esse "logo a seguir", segundo o autor, seria apreciado de acordo com a boa-fé objetiva, “de acordo com o tempo que é razoável supor deva ser despendido para a propositura, nem sempre possível antes do vencimento da prestação, o que, assim, não pode impedir a aplicação da teoria". ${ }^{371}, 372$

\footnotetext{
${ }^{367}$ Art. 438. ${ }^{\circ}$ Mora da parte lesada. A parte lesada não goza do direito de resolução ou modificação do contrato, se estava em mora no momento em que a alteração das circunstâncias se verificou.

${ }^{368}$ BORGES, Nelson. A teoria da imprevisão no Direito Civil e no Processo Civil. São Paulo: Malheiros, 2002. p. 315.

369 SANTOS, Regina Beatriz Tavares da Silva Papa dos. Cláusula 'Rebus Sic Stantibus', ou Teoria da Imprevisão. Revisão Contratual. Belém: CEJUP, 1989. p. 38.

${ }^{370}$ ROPPO, Enzo. O contrato. Coimbra: Almedina, 1977. p. 264.

${ }^{371}$ GODOY, Claudio Luiz Bueno de. A função social do contrato: os novos princípios contratuais. 3. ed. São Paulo: Saraiva, 2009. p. 68.

${ }^{372}$ No mesmo sentido, Laura Coradini Frantz entende que o direito à resolução ou revisão do contrato por excessiva onerosidade é um direito potestativo e que, portanto, está submetido a prazo decadencial. Não prevendo o legislador pátrio o prazo decadencial, a autora também invoca a boa-fé objetiva, especificamente a figura da supressio, caracterizada por ser uma situação de direito que, não tendo sido exercido durante
} 
Em síntese, afirma Borges: “mutatis mutandis, se a alteração anormal se deu "antes" da ocorrência do estado moratório, mesmo que ele se apresente, goza o devedor do direito de pedir modificação ou extinção do pacto. Acrescente-se que a mora não atua por si mesma. Não pode ser conhecida de ofício. Precisa ser invocada por uma das partes contra a outra, seja a obrigação positiva e líquida, ou ilíquida, quando será indispensável torná-la líquida, por via da interpretação judicial. ${ }^{373}$

$\mathrm{O}$ argumento que sustenta a impossibilidade do devedor de invocar a alteração das circunstâncias quando está em mora advém, a fortiori ratione, do que dispõe o artigo 399 do Código Civil, o qual prevê que "O devedor em mora responde pela impossibilidade da prestação, embora essa impossibilidade resulte do caso fortuito ou de força maior, se estes ocorrerem durante o atraso; salvo se provar isenção de culpa, ou que o dano sobreviria ainda quando a obrigação fosse oportunamente desempenhada".

Nesse sentido, Carvalho Fernandes coloca que "se o devedor em mora suporta o risco, muito mais deve suportar a maior dificuldade de cumprimento da prestação". 374

Segundo Claudio Luiz Bueno de Godoy, o artigo $1.108^{375}$ do Código Civil argentino expressamente exige que não haja a mora debitoris. ${ }^{376}, 377$

É possível, ainda, que haja mora creditoris, quando por um evento imputável ao credor, a obrigação, embora pontualmente oferecida e possível por parte do devedor, tenha se tornado excessivamente onerosa para o devedor. Também neste caso o devedor poderá invocar a alteração das circunstâncias, pois "seria injusto que o devedor fosse afectado pelo agravamento posteriormente decorrente de uma alteração das circunstâncias". 378

determinadas circunstâncias e lapso temporal, não possa mais sê-lo por contrariar a boa-fé. (FRANTZ, Laura Coradini. Revisão dos contratos: elementos para sua construção dogmática. São Paulo: Saraiva, 2007. p. 159).

${ }^{373}$ BORGES, Nelson. A teoria da imprevisão no Direito Civil e no Processo Civil. São Paulo: Malheiros, 2002. p. 316.

${ }^{74}$ CARVALHO FERNANDES, Luís A. A teoria da imprevisão no Direito Civil português. Lisboa: Quid Juris?, 2001. p. 111.

${ }^{375}$ Art. 1.108: “(...) nos contratos bilaterais comutativos e nos unilaterais onerosos e comutativos de execução diferida ou continuada, se a prestação a cargo de uma das partes se tornar excessivamente onerosa, por acontecimentos extraordinários e imprevisíveis, a parte prejudicada poderá demandar a resolução do contrato. O mesmo princípio se aplicará aos contratos aleatórios, quando a excessiva onerosidade se produza por causas estranhas ao risco próprio do contrato. (...) Não procederá a resolução, se o prejudicado houver obrado com culpa ou estiver em mora (...)".

${ }^{376}$ GODOY, Claudio Luiz Bueno de. A função social do contrato: os novos princípios contratuais. 3. ed. São Paulo: Saraiva, 2009. p. 68.

${ }^{377}$ O Tribunal de Justiça do Estado de São Paulo já decidiu em ação revisional que a mora do devedor é óbice à aplicação da teoria da imprevisão (Apelação com revisão n. 9065781-74.2004.8.26.0000, 2a Câmara de Direito Privado, Comarca de São Paulo, j. 11.03.2008, Rel. Santini Teodoro).

${ }^{378}$ CARVALHO FERNANDES, Luís A. A teoria da imprevisão no Direito Civil português. Lisboa: Quid Juris?, 2001. p. 292. 
O artigo $1207^{379}$ do Código Civil italiano prevê que, havendo a mora do credor, ficará a seu encargo a impossibilidade da prestação superveniente por causa não imputável ao devedor. No Brasil, o artigo 400 do Código Civil impõe ao credor moroso a obrigação de receber a coisa devida pela "estimação mais favorável ao devedor, se o seu valor oscilar entre o dia estabelecido para o pagamento e o da sua efetivação".

O já referido Projeto de Lei n. 276/07 propõe a inserção de um parágrafo ao artigo 472 (que se refere ao artigo 478 vigente) tratando do tema e que prevê: "Não pode requerer a revisão do contrato quem se encontrar em mora no momento da alteração das circunstâncias".

\title{
5.2.3 Inimputabilidade
}

Para que se possa rever o contrato ou modificá-lo em decorrência da alteração das circunstâncias, faz-se necessário que esta alteração não seja imputável à parte lesada, ou seja,

[...] o acontecimento extraordinário causador do dano iminente - ou supressão do suporte contratual - não pode ter sido provocado por quem invoca o benefício da imprevisibilidade [...] tanto é responsável o que, no instante vinculativo, plantou a semente da alteração da base contratual como o que, podendo evitar a ocorrência da modificação, permaneceu inerte. Sinteticamente: é tão culpado o criador da causa como o que, podendo evitar a ocorrência da modificação, permaneceu inerte. ${ }^{380}$

No mesmo sentido Carvalho Fernandes sustenta que:

\begin{abstract}
A responsabilidade do contraente pela alteração pode respeitar tanto à causa da sua verificação, como à produção do nexo de causalidade entre a alteração e o contrato. Isto é, o contraente não pode valer-se da imprevisão, quer quando tenha colocado a causa que provocou a modificação do condicionalismo existente à data do contrato, quer quando não tenha evitado, podendo e devendo fazê-lo, que a modificação verificada exercesse influência no contrato. ${ }^{381}$
\end{abstract}

\footnotetext{
${ }^{379}$ Na língua original: Art. 1207. Effetti. Quando il creditore è in mora, è a suo carico l'impossibilità della prestazione sopravvenuta per causa non imputabile al debitore (1256 e seguenti, 1673). Non sono più dovuti gli interessi né i frutti (820) della cosa che non siano stati percepiti dal debitore.

Il creditore è pure tenuto a risarcire i danni derivati dalla sua mora (1224) e a sostenere le spese per la custodia e la conservazione della cosa dovuta.

Gli effetti della mora si verificano dal giorno dell'offerta, se questa è successivamente dichiarata valida con sentenza passata in giudicato (Cod. Proc. Civ. 324) o se è accettata dal creditore.

${ }^{380}$ CARVALHO FERNANDES, Luís A. A teoria da imprevisão no Direito Civil português. Lisboa: Quid Juris?, 2001. p. 109.

${ }^{381}$ O referido artigo que está inserido em capítulo que trata da onerosidade excessiva prevê: As normas dos artigos precedentes não se aplicam aos contratos aleatórios por sua natureza (1879) ou por vontade das partes (1448, 1472).
} 
Em regra, não se admite a associação da situação anormal e imprevisível a condições pessoais dos contratantes, "mas sim a eventos genéricos, de impacto geral, que afetem a prestação do contrato, o equilíbrio que lhe é inerente". ${ }^{382}$ Ressalva-se, entretanto, posicionamento já mencionado no item 5.1.1, do Capítulo V, de autores como Antonio Junqueira de Azevedo e Cláudia Lima Marques que admitem uma análise de ordem subjetiva para os contratos de consumo, por exemplo.

Assim, geralmente restará inaplicável a revisão se a onerosidade excessiva decorrer de "dificuldade financeira, até por desemprego superveniente ${ }^{383}$, de um dos contratantes, circunstância pessoal, e não de afetação direta da prestação". 384

Sobre o tema, José de Oliveira Ascensão ensina: "Decerto que a parte não pode invocar em seu benefício a alteração das circunstâncias se a sua mora foi causal para que aquela relação fosse atingida por essa alteração; quando portanto, se tivesse cumprido, a relação já estaria extinta". 385

O Código Civil peruano, em seu artigo 1443 prevê: "No procede la acción por excesiva onerosidad de la prestación cuando su ejecución se ha diferido por dolo o culpa de la parte perjudicada".

Entretanto, se o estado moratório decorre da alteração da base negocial, possível intentar-se a ação revisional, conforme já analisado anteriormente no item 1.2.2 deste capítulo.

Com relação à doutrina da frustração do contrato, Andrew A. Schwartz afirma que haverá escusa no cumprimento do contrato apenas se o desequilíbrio resultar de um evento exógeno, ou seja, um evento que não seja controlável pelas partes, como, por exemplo, a mudança de gosto dos consumidores. Ao contrário, o autor considera como um evento endógeno uma campanha publicitária mal executada.

A inimputabilidade da parte lesada em razão da alteração das circunstâncias é

\footnotetext{
382 GODOY, Claudio Luiz Bueno de. A função social do contrato: os novos princípios contratuais. 3. ed. São Paulo: Saraiva, 2009. p. 69.

${ }^{383}$ Nesse sentido julgou o Tribunal de Justiça do Estado de São Paulo: Ementa: Ação de revisão contratual c.c. manutenção na posse. Compromisso de venda e compra. Ação improcedente. Inaplicabilidade da 'Teoria' da imprevisão. Não comprovação de fato extraordinário ou imprevisível após a formação do contrato. Mora do promitente comprador que é óbice à sua aplicação. Alegações genéricas de dificuldades econômicas insuficientes para a revisão judicial do contrato. Inaplicabilidade do art. 479 do Código Civil de 2002. Honorários advocatícios. Aplicação do art. 20, §49 do CPC. Redução eqüitativa. Recurso provido em parte. (Apelação 9065781-74.2004.8.26.0000, Rel. Santini Teodoro, Comarca de São Paulo, 2a Câmara de Direito Privado, j. 11.03.2008).

${ }^{384}$ GODOY, Claudio Luiz Bueno de. Op. cit., p. 69.

385 ASCENSÃO, José de Oliveira. Alteração das circunstâncias e justiça contratual no novo Código Civil. In: Revista Trimestral de Direito Civil. São Paulo, Padma, v. 25, p. 113-118, janeiro/março 2006.
} 
exigida ainda que a lei não a exija expressamente ${ }^{386}$, como é o caso da legislação brasileira, pois parece evidente que aquela não possa se insurgir contra seu próprio comportamento danoso.

\subsection{APLICAÇÃO AOS CONTRATOS ALEATÓRIOS}

De início, poder-se-ia imaginar que onerosidade excessiva não se aplica aos chamados contratos aleatórios, como os contratos de jogo e renda vitalícia, nos quais "há incerteza para as duas partes sobre se a vantagem esperada será proporcional ao sacrifício"387.

Nas palavras de Inocêncio Galvão Telles, "nos contratos aleatórios reina incerteza sobre o seu significado patrimonial para cada um dos contraentes; tem-se a expectativa de ganhar mas também se corre o risco de perder". 388

Entretanto, a questão relativa à possibilidade de revisão ou modificação de um contrato aleatório não é tão simples assim.

O Código Civil italiano prevê expressamente em seu artigo 1469 a exclusão da alegação de onerosidade excessiva para os contratos aleatórios ${ }^{389}$, enquanto o Código Civil brasileiro, por seu turno, silencia a este respeito.

Já o Código Civil argentino, prevê em seu artigo 1198:

Los contratos deben celebrarse, interpretarse y ejecutarse de buena fe y de acuerdo con lo que verosímilmente las partes entendieron o pudieron entender, obrando con cuidado y previsión. En los contratos bilaterales conmutativos y en los unilaterales onerosos y conmutativos de ejecución diferida o continuada, si la prestación a cargo de una de las partes se tornara excesivamente onerosa, por acontecimientos extraordinarios $e$ imprevisibles, la parte perjudicada podrá demandar la resolución del contrato. El mismo principio se aplicará a los contratos aleatorios cuando la excesiva onerosidad se produzca por causas extrañas al riesgo propio del contrato. En los contratos de ejecución continuada la resolución no

\footnotetext{
${ }^{386}$ CARVALHO FERNANDES, Luís A. A teoria da imprevisão no Direito Civil português. Lisboa: Quid Juris?, 2001. p. 109.

${ }^{387}$ GOMES, Orlando. Contratos. Rio de Janeiro: Forense, 2007. p. 74.

388 GALVÃO TELLES, Inocêncio. Manual dos contratos em geral. Coimbra: Coimbra Editora, 2010. p. 483.

${ }^{389}$ Sobre o direito italiano, Enzo Roppo afirma: "Se o fundamento do instituto do qual nos ocupamos consiste na justa e racional repartição entre os contraentes dos riscos conexos com a verificação de circunstâncias futuras, é compreensível que o remédio da resolução não deva operar para os contratos que as partes tenham inteiramente moldado sobre o risco (art. 1469. ${ }^{\circ}$ Cód. Civ.): são os contratos aleatórios, onde a medida das prestações recíprocas, ou até a susceptibilidade de as obter, são confiadas, pelos contraentes, ao acaso, que cada um espera evolua em sentido favorável para si. São contratos de especulação sobre o destino: pertence à sua própria função, à sua própria causa, que com eles se possam ganhar muito, mas também perder muito, ou tudo (é o caso do seguro, do jogo, da aposta, da renda vitalícia, etc.). Aqui não há o problema da tutela contra um certo nível de risco, porque as partes anuíram em correr o máximo de risco”. (ROPPO, Enzo. O contrato. Coimbra: Almedina, 1977. p. 259).
} 
alcanzará a los efectos ya cumplidos. No procederá la resolución, si el perjudicado hubiese obrado con culpa o estuviese en mora. La otra parte podrá impedir la resolución ofreciendo mejorar equitativamente los efectos del contrato.

Trata-se, como afirmam Iturraspe e Piedecasas, da adequação do contrato repartindo equitativamente os riscos, ou melhor, o efeito do fato "distorsivo" sobre o contrato para evitar um resultado injusto. ${ }^{390}$

A aleatoriedade do contrato pode referir-se à própria existência da contraprestação, quando então é conhecido como emptio spei, ou pode referir-se à quantidade ou extensão da contraprestação, quando é conhecido como emptio rei speratae. Na primeira hipótese, a parte suporta o risco de inexistência da coisa, enquanto na segunda, suporta um risco relativo à quantidade. $^{391}$

Grande parte da doutrina brasileira entende que não é possível a revisão ou modificação do contrato por alteração das circunstâncias se esta recair na álea típica do contrato aleatório, ou, ainda, se o desequilíbrio contratual foi "causado pelo fato futuro expressamente previsto" 392 , conforme já analisado acima. Entretanto, em se tratando de alteração de circunstâncias decorrente de um risco anormal ou extraordinário ${ }^{393}$, a revisão ou a modificação poderão retomar o equilíbrio contratual.

Sobre o tema, Luiz Philipe Tavares de Azevedo Cardoso elucida:

[...] é de rigor a não incidência do remédio por onerosidade excessiva na álea típica dos contratos aleatórios, salvo a exceção abaixo citada. E isso é assim simplesmente pelo fato de esses contratos existirem validamente no direito brasileiro. A alegação de onerosidade excessiva seria, nesse caso, contra a ontologia do próprio contrato. Não seria nem necessário um artigo de lei para proibir-lhe a incidência. Já para os fatos excluídos da álea típica dos aleatórios, o regime dos comutativos referente à onerosidade excessiva, dada a ausência de texto legal que o vede, é plenamente aplicável. É importante lembrar ainda a exceção disposta para o contrato de seguro, consistente na possibilidade de revisão do prêmio em favor do segurado, caso a redução do risco seja considerável. Trata-se de uma interessante possibilidade de reequilíbrio do contrato pelo desequilíbrio superveniente de probabilidades, apenas em favor do segurado e limitada pela hipótese legislativa. ${ }^{394}$

390 ITURRASPE, Jorge Mosset; PIEDECASAS, Miguel A. La revisión del contrato. Santa Fe: Rubinzal Culzoni, 2008. p. 109.

391 FRANTZ, Laura Coradini. Revisão dos contratos: elementos para sua construção dogmática. São Paulo: Saraiva, 2007. p. 162.

392 CARDOSO, Luiz Philipe Tavares de Azevedo. A onerosidade excessiva no Direito Civil Brasileiro. Dissertação (Mestrado) - Universidade de São Paulo, São Paulo, 2010. p. 161.

${ }^{393}$ FRANTZ, Laura Coradini. Op. cit., p. 164.

${ }^{394}$ CARDOSO, Luiz Philipe Tavares de Azevedo. Op. cit. p. 162. 
J. M. Othon Sidou, forte no pensamento de Artur Rocha, há muitos anos já ensinava:

O problema para deferir à teoria da superveniência livre trânsito na esfera dos contratos a risco está unicamente, como ensina Artur Rocha, em distinguir as áleas previsíveis das imprevisíveis, os riscos normalmente distinguidos no contrato dos riscos, em face de cada caso concreto, que se podem ter como incomuns ou supervenientes. ${ }^{395}$

Este autor posicionou-se, portanto, no sentido de admitir a revisão do contrato aleatório desde que a onerosidade excessiva decorra de um risco imprevisível, "alheio a qualquer manifestação de vontade", e que não decorra "dos riscos normais do contrato". 396

Karl Larenz já havia se pronunciado sobre o tema afirmando que não devem ser consideradas as transformações das circunstâncias que, sendo previsíveis, fazem parte dos riscos assumidos no contrato. ${ }^{397}$

Orlando Gomes ${ }^{398}$ também se posiciona de modo favorável à revisão de contrato aleatório, assim como Junqueira Azevedo ${ }^{399}$. Também favorável à possibilidade de revisão por excessiva onerosidade nos contratos aleatórios, Claudio Luiz Bueno de Godoy afirma:

Cada qual dos contratos aleatórios induz uma álea específica, vale dizer, um dado especial sobre o qual incide o fator aleatório, na renda vitalícia a duração, no seguro a época ou a ocorrência em si do fato, destarte fora do que, como acentua Ruy Rosado de Aguiar Júnior, pode sim atuar causa de desequilíbrio do ajuste que reclame correção, por obra da justiça contratual. $^{400}$

Alfredo José Rodrigues Rocha de Gouveia afirma ser possível a revisão ou modificação por alteração das circunstâncias nos contratos aleatórios desde que a alteração não recaia na álea normal do contrato. ${ }^{401}$

A possibilidade de revisão por onerosidade excessiva nos contratos aleatórios é exemplificada por Manoel Miranda Canales nos seguintes termos: venda que faz uma

\footnotetext{
395 SIDOU, J. M. Othon. A cláusula “Rebus sic stantibus” no Direito Brasileiro. Rio de Janeiro: Freitas Bastos, 1962. p. 129.

396 Ibid., p. 129.

${ }^{397}$ LARENZ, Karl. Base del Negocio Juridico y Cumplimiento de los Contratos. Granada: Comares, 2002. p. 212.

${ }^{398}$ GOMES, Orlando. Contratos. Rio de Janeiro: Forense, 2007. p. 217.

399 AZEVEDO, Antonio Junqueira de. Relatório brasileiro sobre a revisão contratual apresentado para as Jornadas Brasileiras da Associação Henri Capitant. In ___. Novos estudos e pareceres de direito privado. São Paulo: Saraiva, 2009, p. 191.

${ }^{400}$ GODOY, Claudio Luiz Bueno de. A função social do contrato: os novos princípios contratuais. 3. ed. São Paulo: Saraiva, 2009. p. 40-41.

401 ROCHA DE GOUVEIA, Alfredo José Rodrigues. Da teoria da imprevisão nos contratos civis. Lisboa: FDUL, 1958. p. 55.
} 
embarcação pesqueira da extração que obtenha em uma saída, mas que, em consequência de um maremoto, perca todos os peixes que enchiam seus porões. ${ }^{402}$

Outro exemplo é citado por Carvalho Fernandes:

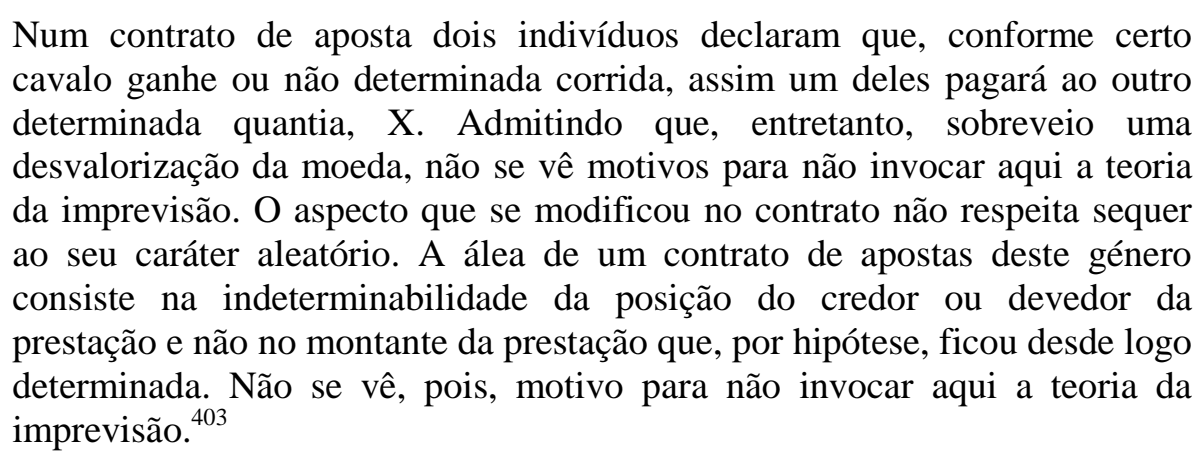

Este autor menciona ainda a possibilidade de revisão dos contratos relativamente aleatórios que são aqueles contratos celebrados durante situações anormais, como, por exemplo, durante uma guerra, entendendo que ainda assim, embora o risco que cabe a cada um dos contraentes seja maior, ele não é ilimitado e que "é tudo questão de determinação da álea normal do contrato, para saber quando se pode dizer que ela foi superada por determinada alteração de circunstâncias".404

Entende-se, portanto, que nos contratos "relativamente aleatórios" as partes estão sujeitas a um risco maior e o que interessa é "saber se são ou não relevantes alterações da sua economia originária, mas para fixar os limites a partir dos quais tais alterações se devem considerar excessivas". ${ }^{405}$ Ou seja, há uma normalidade dentro da situação que é considerada anormal e que os riscos que estão dentro deste limite de normalidade devem ser suportados pelas partes.

\subsection{A REVISÃo E A APLICAÇÃo DO ARTIGO 479 DO CÓDIGO CIVIL}

O artigo 479 dispõe que "A resolução poderá ser evitada, oferecendo-se o réu a modificar equitativamente as condições do contrato".

Uma interpretação do artigo poderia levar à crença de que somente ao réu na demanda (credor da prestação excessivamente onerosa) seria ofertada a possibilidade de

\footnotetext{
${ }^{402}$ CANALES, Manuel Miranda. Derecho de los contratos. Lima: Cultural Cuzco, 1988. p. 57.

${ }^{403}$ CARVALHO FERNANDES, Luís A. A teoria da imprevisão no Direito Civil português. Lisboa: Quid Juris?, 2001. p. 122.

${ }^{404}$ Ibid., p. 125.

${ }^{405}$ ROCHA DE GOUVEIA, Alfredo José Rodrigues. Da teoria da imprevisão nos contratos civis. Lisboa: FDUL, 1958. p. 58.
} 
requerer a alteração equitativa do contrato. Entretanto, admite-se a propositura da ação revisional pelo próprio prejudicado pela alteração das circunstâncias. Aliás, a doutrina pátria tem entendido, com apoio no princípio da conservação dos negócios jurídicos, que a ação proposta pelo prejudicado em razão da excessiva onerosidade possa versar sobre uma revisão do contrato, ainda que na hipótese de aplicação do artigo 478. ${ }^{406} 407$

Junqueira de Azevedo já afirmava: "uma das partes, já de início, pode pedir a revisão e, na sentença, pode o juiz rever o contrato, desde que pelo menos um dos contratantes assim tenha pedido". 408

Nesse sentido, a III Jornada de Direito Civil elaborou o enunciado n. 176: "Em atenção ao princípio da conservação dos negócios jurídicos, o art. 478 do Código Civil de 2002 deverá conduzir sempre que possível, à revisão judicial do contrato e não à resolução contratual". Outro enunciado, o de número 367, desta vez elaborado pela IV Jornada de Direito Civil, assenta que "Em observância ao princípio da conservação do contrato, nas ações que tenham por objeto a resolução do pacto por excessiva onerosidade, pode o juiz modificá-lo equitativamente, desde que ouvida a parte autora, respeitada a sua vontade e observado o contraditório".

J. M. Othon Sidou já se posicionava neste sentido afirmando:

Na aplicação da teoria da imprevisão, ou superveniência, a jurisprudência alemã aferra-se ao princípio de que "a justiça tem de esforçar-se por manter o contrato, modificando-o". Não há cogitar de uma sub-rogação e muito menos de uma subordinação de vontade, porém apenas de um caminho preferencial, ou prioritário, com isto significando não se deixa às partes um concurso eletivo, ad libitum - querer a revisão ou preferir a rescisão; porque há um iter a percorrer. Primeiramente, portanto, a tentativa de reconciliar, e só depois, por ineficácia deste esforço, deve pensar-se na desvinculação. ${ }^{409}$

Conforme coloca Wladimir Alcibíades Marinho Falcão Cunha,

[...] a melhor opção será sempre se ofertar à parte prejudicada a

\footnotetext{
${ }^{406} \mathrm{Na}$ Argentina, a doutrina também se preocupa com a interpretação de dispositivo semelhante ao brasileiro (art. 1198 do Código Civil Argentino). Os fundamentos para a possibilidade de imediata propositura de ação revisional vão desde observância ao princípio da conservação dos contratos à hermenêutica finalista ou teleológica (ITURRASPE, Jorge Mosset; PIEDECASAS, Miguel A. La revisión del contrato. Santa Fe: Rubinzal Culzoni, 2008. p. 469-475).

${ }^{407} \mathrm{O}$ artigo 437 do Código Civil português contempla expressamente a possibilidade da parte lesada pleitear a resolução ou a modificação do contrato segundo juízos de equidade (Nota 305).

${ }^{408}$ AZEVEDO, Antonio Junqueira de. Relatório brasileiro sobre a revisão contratual apresentado para as Jornadas Brasileiras da Associação Henri Capitant. In: . Novos estudos e pareceres de direito privado. São Paulo: Saraiva, 2009, p. 193.

${ }^{409}$ SIDOU, J. M. Othon. A cláusula "Rebus sic stantibus" no Direito Brasileiro. Rio de Janeiro: Freitas Bastos, 1962. p. 134.
} 
possibilidade de revisão judicial da avença, quando rompido o equilíbrio contratual. Tal pode ser dito porque vigora, no direito obrigacional brasileiro contemporâneo, uma diretiva que ordena que os contratos, não obstante se permita a sua revisão, devam, sempre que possível, ser conservados, e não resolvidos, ou anulados. Trata-se do princípio da conservação dos contratos. $\mathrm{Na}$ realidade, hodiernamente, talvez mais do que em qualquer outra época, aos contratantes prejudicados, de normal, não interessa a resolução contratual, com o retorno ao status quo ante, mas sim que o contrato seja efetivamente cumprido, porém, de forma equânime. É dizer, a ocorrência de um acontecimento superveniente e imprevisível, que altera a relação de equivalência das prestações, não significa necessariamente que a parte prejudicada pela onerosidade excessiva queira desistir do contrato, sendo, ao contrário, até mais provável que pretende a sua perpetuação. O contrato há de se conservar e durar no tempo, eis que a finalidade central de toda relação obrigacional é de ser adimplida. Observe-se, assim, que o não ofertamento da possibilidade de revisão contratual, mas tão-somente a de resolução contratual, impõe uma apenação suplementar para a parte já prejudicada pela onerosidade excessiva. A contrario sensu, deixar a opção de requerer a revisão somente à parte não prejudicada, como prevê o art. 479, significa-lhe uma segunda premiação. ${ }^{410}$

Este autor fundamenta ainda a revisibilidade, não só com base no princípio da conservação dos negócios jurídicos, mas na máxima jurídica de que "aquele que pode fazer o mais, ou seja, pedir a resolução, pode fazer o menos, isto é, pedir a revisão do contrato". ${ }^{411}$

Marcos de Almeida Villaça Azevedo ensina: "Entre a revisão e a resolução do contrato, a primeira parece ser o caminho menos tortuoso, pois possibilita a manutenção da relação jurídica contratual e, conseqüentemente, que esta continue exercendo seu relevante papel na sociedade". ${ }^{412}$ Também Nelly Potter manifestou-se neste sentido afirmando que "não seria admissível que a solução prevista pelo legislador fosse incompatível com a finalidade primacial perseguida pelo instituto, que é o retorno à equidade ou ao equilíbrio contratual". ${ }^{413}$

Por fim, Iturraspe e Piedcasas ${ }^{414}$ rechaçam a resolução contratual como único remédio utilizando, entre outros, os seguintes argumentos: i) seria uma solução parcial ao desequilíbrio superveniente; ii) não operaria a correção nem a negociação, mas "mataria" o contrato; iii) traduziria uma visão clássica, baseada na autonomia da vontade e na imperatividade das cláusulas; iv) excluiria a possibilidade de conservação do negócio mutuamente querido; v) traduziria a desconfiança nos juízes; vi) outorgada ao prejudicado

\footnotetext{
${ }^{410}$ CUNHA, Wladimir Alcibíades Marinho Falcão. Revisão judicial dos contratos: do Código de Defesa do Consumidor ao Código Civil de 2002. São Paulo: Método, 2007. p. 220.

${ }^{411}$ Loc. cit.

412 AZEVEDO, Marcos de Almeida Villaça. Onerosidade Excessiva e desequilíbrio contratual supervenientes Tese (Doutorado) - Universidade de São Paulo, São Paulo, 2002. p. 107.

413 POTTER, Nelly. Revisão e resolução dos contratos no Código Civil conforme perspectiva CivilConstitucional. Rio de Janeiro: Lumen Juris, 2009. p. 198.

${ }^{414}$ ITURRASPE, Jorge Mosset; PIEDECASAS, Miguel A. La revisión del contrato. Santa Fe: Rubinzal Culzoni, 2008. p. 449-450.
} 
como único remédio, seria injusta; vii) outorgada ao beneficiado, seria algo utópico e ilusório, pois importaria renunciar a uma "vantagem" econômica ou patrimonial; viii) outorgaria ao beneficiado uma ação que se nega ao prejudicado.

Entretanto, tem-se entendido que a revisão não pode ser imposta pelo juiz por sua própria iniciativa, isto é, é inadmissível a "revisão directa pelo juiz". ${ }^{415} \mathrm{Se}$ as partes concordam com a revisão, mas não nos seus termos, aí sim o magistrado deverá julgar tendo em vista o critério de equidade. Ainda, é de se ressaltar que a revisão será inócua se for incapaz de trazer equilíbrio ao contrato, restando como único remédio a via rescisória.

Um problema que pode advir do disposto no artigo 479 está na "oferta" buscando uma modificação equitativa das condições do contrato. Os italianos Rodolfo Sacco e Giorgio de Nova, ao comentarem dispositivo semelhante contido no artigo $1467^{416}$ do Código Civil italiano, sustentam que seria desarrazoado recair ao ofertante o risco de uma errônea valoração da prestação necessária para devolver equilíbrio ao contrato e que parece lógico consentir à parte que peça ao juiz que a determine. Segundo estes autores, a proposta deve ser no sentido de reconduzir o contrato à equidade. ${ }^{417}$

A doutrina brasileira, entretanto, entende que a oferta do réu nos moldes do artigo 479 deve ser "certa e específica, de modo que o autor possa avaliar a conveniência de aceitála para manter o contrato" e que a intervenção do juiz no sentido de modificar o contrato pela crença do que ele considera ser justo não poderá ser feita, a não ser se forem levados em consideração os critérios já estabelecidos pelas partes. Ou seja, são elas que, pelo conhecimento do negócio firmado e suas peculiaridades, podem dar suporte ao juiz "para modificar as condições acordadas". 418

Giuliana Bonnano Schunck ressalva, entretanto, que na hipótese de revisão com fundamento no artigo 317, o juiz poderia modificar o contrato "sem suporte das partes", pois a revisão do valor da prestação, em geral, é realizada com base em índices oficiais ou

\footnotetext{
${ }^{415}$ CARVALHO FERNANDES, Luís A. A teoria da imprevisão no Direito Civil português. Lisboa: Quid Juris?, 2001. p. 143.

${ }^{416}$ Do original: Art. 1467 Contratto con prestazioni corrispettive

Nei contratti a esecuzione continuata o periodica ovvero a esecuzione differita, se la prestazione di una delle parti è divenuta eccessivamente onerosa per il verificarsi di avvenimenti straordinari e imprevedibili, la parte che deve tale prestazione può domandare la risoluzione del contratto, con gli effetti stabiliti dall'art. 1458 (att. 168).

La risoluzione non può essere domandata se la sopravvenuta onerosità rientra nell'alea normale del contratto.

La parte contro la quale è domandata la risoluzione può evitarla offrendo di modificare equamente le condizioni del contratto $(962,1623,1664,1923)$.

${ }^{417}$ SACCO, Rodolfo; DE NOVA, Giorgio. II contrato. 3.ed. Torino: Editrice Torinese. Tomo Secondo, 2004. p. $720-721$.

${ }^{418}$ SCHUNCK, Giuliana Bonanno. A onerosidade excessiva superveniente no Código Civil: críticas e questões controvertidas. São Paulo: LTR, 2010. p. 136.
} 
preestabelecidos. $^{419}$

A modificação, certifique-se, pode consistir em alteração da prestação pecuniária, modificação da modalidade de execução do contrato, alteração no tempo do cumprimento do contrato ou do lugar de cumprimento, entre tantas outras possibilidades de alteração da prestação que tragam equilíbrio ao contrato. Ainda, Iturraspe e Piedecasas exemplificam a hipótese de supressão de uma cláusula, a modificação da intensidade de uma cláusula e também a ampliação do conteúdo do contrato. ${ }^{420}$

Reconduzir o contrato à equidade não é tarefa fácil para o magistrado, muito embora se tenha que considerar que "as decisões segundo a equidade não podem deixar de ser justas, isto é, têm de consagrar a ideia fundamental de Justiça que domina o sistema jurídico em cada estágio concreto de sua evolução histórica". ${ }^{21}$

A equidade, para Fernando Rodrigues Martins, ganha um valor ontológico para a justiça contratual, "já que se comporta como a justiça efetivamente aplicada". ${ }^{422}$ Este mesmo autor sustenta ainda que o recurso à equidade sem o chamado legal permissivo, nos moldes do disposto no artigo 127 do Código de Processo Civil, e que não levar em conta os efeitos econômicos e sociais do contrato "nos moldes adequados ao anseio das partes, coloca em xeque e de lado aspectos valiosíssimos como a confiança, a segurança no tráfego jurídico e a força obrigatória". 423

Segundo Carvalho Fernandes, sinteticamente, a demonstração da justeza do contrato é feita por duas vias: i) não pode acarretar uma pura transferência das consequências da alteração das circunstâncias; ii) o lesado não pode reclamar a modificação do negócio enquanto as consequências da alteração estiverem cobertas pelo seu risco normal ou se contiverem em limites tais que a outra parte possa continuar a exigir o cumprimento sem violação grave da boa-fé ${ }^{424}$. Em razão da utilização das referidas duas vias, para o autor, a função da equidade seria assegurar "apenas uma repartição justa das conseqüências excessivas - segundo a boa fé -, decorrentes da alteração das circunstâncias". ${ }^{425}$

Entre os critérios citados por este autor para que sobrevenha uma decisão fundada na

\footnotetext{
${ }^{419}$ SCHUNCK, Giuliana Bonanno. A onerosidade excessiva superveniente no Código Civil: críticas e questões controvertidas. São Paulo: LTR, 2010. p. 131.

${ }^{420}$ ITURRASPE, Jorge Mosset; PIEDECASAS, Miguel A. La revisión del contrato. Santa Fe: Rubinzal Culzoni, 2008. p. 457-460.

${ }^{421}$ CARVALHO FERNANDES, Luís A. A teoria da imprevisão no Direito Civil português. Lisboa: Quid Juris?, 2001. p. 301.

${ }^{422}$ MARTINS, Fernando Rodrigues. Princípio da justiça contratual. São Paulo: Saraiva, 2009. p. 133.

${ }^{423}$ Ibid., p. 135.

${ }^{424}$ CARVALHO FERNANDES, Luís A. Op. cit., p. 302-303.

425 Ibid., p. 303.
} 
equidade, pode-se mencionar: i) qual das partes investiu mais do que a outra na estabilidade do regime negocial e "a partir daí definiu programas de acção que resultariam profundamente abalados se a sua prestação viesse a ser modificada em termos gravosos"; ii) o momento em que a alteração das circunstâncias ocorre se o contrato for de execução periódica, continuada ou diferida, visto que as consequências não serão as mesmas conforme ocorram no começo de execução ou numa fase final, "quando esteja já substancialmente cumprida, pela parte lesada, a sua prestação"; iii) o comportamento das partes na execução do contrato, no sentido de “averiguar se estas contribuíram para eliminar ou amortecer as consequências da alteração das circunstâncias". Ou seja, seria na ponderação conjunta e relativa destes fatores que o julgador deverá encontrar a "bitola da repartição, entre as partes, dos danos excessivos que a exigência da execução rigorosa do contrato envolveria para uma delas e, nessa base, operar a sua modificação",426.

Nelly Potter indaga ainda quanto à redução à equidade proposta pelo artigo 479 se há uma diferença entre restabelecer o equilíbrio e suprir a onerosidade excessiva, ou seja, "se a relação deve ser reacomodada de modo a restabelecer a proporcionalidade original ou, pelo contrário, se deve limitar a reduzir o que for necessário para que a prestação deixe de ser excessivamente onerosa". Para a referida autora, a busca pela proporção inicialmente encontrada poderia "daria margens a injustiças" e afirma:

[...] se o devedor cuja prestação agravou-se notoriamente sem alcançar uma entidade suficiente para torná-la excessivamente onerosa deverá suportar, resignadamente, a fatalidade de seu destino, por que razão, aquele que atinge o requerido pela lei tem o direito de restabelecer a integralidade da proporção inicial? Certamente, a busca pela reconstrução de um equilíbrio ideal, focando-se na proporção inicialmente encontrada, daria margens a injustiças. ${ }^{427}$

Laura Coradini Frantz, por seu turno, entende que o que se busca na revisão é "mais que o equilíbrio objetivo entre as prestações, que foi destruído por circunstâncias supervenientes, mas o retorno da proporção entre as prestações originariamente fixada pelas partes contratantes". 428

Por fim, outra indagação relativa à aplicação do artigo 479 está relacionada ao

\footnotetext{
${ }^{426}$ CARVALHO FERNANDES, Luís A. A teoria da imprevisão no Direito Civil português. Lisboa: Quid Juris?, 2001. p. 306.

427 POTTER, Nelly. Revisão e resolução dos contratos no Código Civil conforme perspectiva CivilConstitucional. Rio de Janeiro: Lumen Juris, 2009. p. 178-180.

428 FRANTZ, Laura Coradini. Revisão dos contratos: elementos para sua construção dogmática. São Paulo: Saraiva, 2007. p. 150.
} 
instrumento utilizado pelo réu para oferecer a modificação equitativa. Nelly Potter ${ }^{429}$, por exemplo, sustenta que o momento adequado é a contestação, argumentando que seria neste ato que o réu se encontra diante da alternativa de negar ou reconhecer a existência da onerosidade excessiva. Com o devido respeito a este posicionamento, entende-se que o instrumento adequado para o réu seria a reconvenção, conforme se analisará oportunamente no item 5.7 deste capítulo.

Nesse sentido, Giuliana Bonanno Schunck afirma: "Sem dúvida, seria mais benéfico a ambas as partes tentar, em primeiro lugar, conservar o contrato, e não deixar esta como a última opção, a ser aplicada apenas se a outra parte se oferecer a modificar a prestação". 430

Anísio José de Oliveira, antes mesmo da entrada em vigor do Código Civil de 2002, já ensinava: "Opinamos pela revisão como meio preferencial, no entanto o juiz eleger a resolução se o dito meio preferencial for inadmissível ao acaso". 431

Também, Paulo Carneiro Maia, ao tratar do Código Civil de 1916, já propunha, de lege ferenda, a revisão judicial do contrato para o restabelecimento de seu equilíbrio, optando-se pela rescisão em "hipóteses especiais, quando tal acontecimento imprevisível e lesionário torne o contrato inexequíível em sua essência ou em tôdas as sua cláusulas". 432

É de se repetir que existem Projetos de Lei que visam modificar o referido artigo 478, a exemplo do Projeto de Lei n. 3.619/2008 de autoria do Deputado Carlos Bezerra que objetiva excluir do texto o termo "imprevisível" e o Projeto de Lei 6960/2002 ${ }^{433}$ de autoria do então Deputado Ricardo Fiúza que visava limitar a parte prejudicada com a onerosidade da prestação a pedir a revisão contratual, e não sua resolução e também retirar a expressão “com

429 POTTER, Nelly. Revisão e resolução dos contratos no Código Civil conforme perspectiva CivilConstitucional. Rio de Janeiro: Lumen Juris, 2009. p. 175.

${ }^{430}$ SCHUNCK, Giuliana Bonanno. A onerosidade excessiva superveniente no Código Civil: críticas e questões controvertidas. São Paulo: LTR, 2010. p. 83.

${ }^{431}$ OLIVEIRA, Anísio José de. A cláusula "rebus sic stantibus”. Belo Horizonte: [s.n.], 1968. p. 111.

432 MAIA, Paulo Carneiro. Da cláusula rebus sic stantibus. São Paulo: Saraiva, 1959. p. 259.

${ }^{433}$ No Relatório elaborado pela Comissão de Constituição e Justiça e de Redação, houve menção a que, segundo Ricardo Fiúza, o texto deveria ser alterado para "limitar a parte prejudicada com a onerosidade da prestação a pedir a revisão contratual, e não sua resolução como está no Código, e para retirar a expressão "com extrema vantagem para a outra"', O referido relatório firmou-se no sentido de rejeitar a alteração sob os seguintes argumentos: "Examinemos as duas alterações sugeridas. Quanto à primeira, ela não procede porque retira da parte prejudicada o direito de pedir a resilição do contrato que lhe é extremamente oneroso, impondo-lhe uma revisão, que deveria ser apenas opcional, como, de resto, lhe faculta o Código no art. 480, e de transformar o pedido de resolução em revisão se o réu concordar em reduzir equitativamente a prestação contratual. Quanto à segunda, está ela inspirada no Código do Consumidor que em no inciso V do seu art. $6^{\circ}$, e no inciso IV do art. 51 , bem como do inciso III do seu $\S 1^{\circ}$, prevêem revisão e a nulidade de cláusulas excessivamente onerosas para o consumidor. Mas, está previsto no art. 480 que trata-se de contrato em que a uma só parte, como é o caso do Código do Consumidor, cabe a prestação onerosa. A hipótese prevista no art. 478 refere-se ao enriquecimento ilícito de uma parte em detrimento da outra. Se o acontecimento imprevisto prejudica por igual as duas partes não há que se falar em resolução ou revisão do contrato senão por mútuo acordo ou segundo as disposições contratuais". (Disponível em <http://www.camara.gov.br>. Acesso em: 14 jan. 2013). 
extrema vantagem para a outra".

\subsection{APLICAÇÃO DO ARTIGO 480 DO CÓDIGO CIVIL}

O artigo 480 do Código Civil prevê: "Se no contrato as obrigações couberem a apenas uma das partes, poderá ela pleitear que a sua prestação seja reduzida, ou alterado o modo de executá-la, a fim de evitar a onerosidade excessiva”.

O referido artigo, aparentemente, trata dos contratos unilaterais, ou seja, contratos que impõem obrigações para apenas uma das partes, fazendo uma distinção inexistente em países como Portugal e Alemanha, chegando J. M. Othon Sidou ${ }^{434}$ a afirmar que "os códigos de feição mais moderna afastaram a menção à unilateralidade ou bilateralidade do contrato".

Necessária, desta forma, é a distinção entre contratos unilaterais e bilaterais. Segundo Orlando Gomes ${ }^{435}$, o contrato é unilateral se, "no momento em que se forma, origina obrigação, tão-somente, para uma das partes - ex uno latere". Por outro lado, o contrato seria bilateral quando as partes "ocupam, simultaneamente, a dupla posição de credor e devedor. Cada qual tem direitos e obrigações. À obrigação de um corresponde o direito da outra".

Grande parte da doutrina, entretanto, interpreta o artigo 480 de forma que vá além dos contratos unilaterais para atingir também as cláusulas contratuais que estabelecem obrigações a apenas uma das partes, a execução parcial do contrato e, até mesmo, negócios jurídicos unilaterais (e não contratos) em que apenas uma parte tenha assumido obrigações, como, por exemplo, a promessa de recompensa e as ofertas em geral. ${ }^{436}$

Nesse sentido, Antônio Junqueira de Azevedo entende que o artigo 480 não se aplica exclusivamente aos contratos unilaterais, mas também a cláusulas que criam obrigações somente para uma das partes. ${ }^{437}$

Carvalho Fernandes exemplifica a aplicação da imprevisão a negócio unilateral:

Um indivíduo declara num anúncio feito num jornal, que compra, por certa quantia, um livro geralmente considerado raridade bibliográfica, até porque a casa editora declarara que não voltaria a reeditá-lo. Mas pode acontecer que, entre o momento do anúncio e o aparecimento de alguém interessado na

\footnotetext{
${ }^{434}$ SIDOU, J. M. Othon. A cláusula “rebus sic stantibus” no Direito Brasileiro. Rio de Janeiro: Freitas Bastos, 1962. p. 136.

${ }^{435}$ GOMES, Orlando. Contratos. Rio de Janeiro: Forense, 2007. p. 85.

${ }^{436}$ SCHUNCK, A onerosidade excessiva superveniente no Código Civil: críticas e questões controvertidas. São Paulo: LTR, 2010. p. 106.

${ }^{437}$ AZEVEDO, Antonio Junqueira de. (Parecer) Natureza jurídica do contrato de consórcio (sinalagma indireto). Onerosidade excessiva em contrato de consórcio. Resolução parcial do contrato. In: pareceres de direito privado. São Paulo: Saraiva, 2009. p. 368. . Novos estudos e
} 
oferta feita por aquele indivíduo, se verifique uma reedição da obra. Levantam-se aqui problemas em tudo idênticos aos que vimos serem objecto das discussões dos autores a propósito da imprevisão: ou seja, saber se o primeiro indivíduo continua vinculado à declaração feita, se pode pedir uma redução do preço oferecido ou considerar-se mesmo desvinculado da declaração, no caso de o segundo não aceitar a modificação de preço proposto. ${ }^{438}$

Diferentemente do artigo 478, o artigo 480 não prevê a possibilidade de resolução do contrato, mas tão somente a possibilidade de redução da prestação ou alteração do modo de executá-la, a fim de evitar a onerosidade excessiva.

Outra ponderação importante está relacionada ao contrato bilateral sinalagmático em que já houve pagamento de uma das obrigações. Segundo a doutrina, estes contratos continuam sujeitos à possibilidade de ocorrência da onerosidade excessiva, mas a conseqüência "será tão somente a modificação da prestação e não mais a resolução". 439

É assente, portanto, na doutrina ${ }^{440} 441$, a aplicação do artigo 480 ainda que o contrato seja bilateral, e a obrigação de uma parte já estiver executada e restar apenas a obrigação da outra parte.

Luiz Philipe Tavares de Azevedo Cardoso sintetiza:

De todo o exposto, pode-se chegar a uma conclusão a respeito do artigo 480: ele deverá ser aplicado sempre que, embora haja troca econômica (onerosidade) essa troca não esteja espelhada na estrutura obrigacional criada pelo contrato, ou seja, sempre que não haja nexo de interdependência entre obrigações num contrato. Pode ser aplicado, ainda, quando uma das obrigações, nos contratos bilaterais sinalagmáticos já houver sido adimplida. Quando uma obrigação tiver seu correspectivo econômico em uma prestação anterior, e que não tiver obrigação recíproca pendente, utiliza-se o art. 480. O sentido último do dispositivo diz respeito ao fato de ele prever não a resolução do contrato, mas a redução da prestação, ou a alteração do modo de executá-la. ${ }^{442}$

Por fim, resta indagar se o dispositivo será aplicado indistintamente a contratos unilaterais onerosos e gratuitos. Ressalta-se que a doutrina brasileira entende que o Código Civil brasileiro não fez qualquer distinção para a aplicação do artigo 480 quanto a ser o

\footnotetext{
${ }^{438}$ CARVALHO FERNANDES, Luís A. A teoria da imprevisão no Direito Civil português. Lisboa: Quid Juris?, 2001. p. 127.

439 CARDOSO, Luiz Philipe Tavares de Azevedo. A onerosidade excessiva no Direito Civil Brasileiro. Dissertação (Mestrado) - Universidade de São Paulo, São Paulo, 2010. p. 140-141.

${ }^{440}$ GODOY, Claudio Luiz Bueno de. A função social do contrato: os novos princípios contratuais. 3. ed., São Paulo: Saraiva, 2009. p. 66

${ }^{441}$ SCHUNCK, Giuliana Bonanno. A onerosidade excessiva superveniente no Código Civil: críticas e questões controvertidas. São Paulo: LTR, 2010. p. 105.

${ }^{442}$ CARDOSO, Luiz Philipe Tavares de Azevedo. Op. cit. p. 141.
} 
contrato unilateral gratuito ou oneroso.

Giulianna Bonnano Schunck, por exemplo, afirma:

\begin{abstract}
Se o próprio artigo não fez nenhuma restrição ou distinção, entendemos que, até por ser ele mais benéfico que o art. 478, ele deve ser aplicado a todos os contratos unilaterais". ${ }^{443}$ Não obstante este posicionamento, a autora entende que determinadas situações concretas exigem atenção do operador do direito, pois segundo ela, "o art. 480 do Código Civil brasileiro não fala em contratos unilaterais, mas sim em "contratos com obrigações que cabem a apenas uma das partes". Sendo assim, se restar comprovado que em determinado contrato unilateral oneroso (tal como o mútuo feneratício), ambas as partes possuem sacrifícios e vantagens, entendemos que a aplicação do art. 480 pode ser prejudicial a uma das partes, pois, em regra, apenas o devedor (a quem cabe a obrigação de devolver o objeto do mútuo e pagar os acréscimos) poderá socorrer-se do instituto da onerosidade excessiva. Assim, podem ocorrer acontecimentos que obriguem o credor de contratos unilaterais onerosos a pedir a resolução ou revisão do contrato em razão de fato superveniente que gere onerosidade excessiva. Porém, pela regra do art. 480 apenas o devedor poderia valer-se do instituto, não restando nenhuma alternativa ao credor. Entendemos que a regra geral deve ser a aplicação do art. 480 para todos os contratos unilaterais, quer sejam gratuitos ou onerosos. Porém pode haver situações nas quais a regra do art. 480 não seja suficiente para proteger a parte contra a excessiva onerosidade, sendo, assim, necessário nos socorrermos do art. 478, sob o fundamento de que, apesar de o contrato ser unilateral, ambas as partes possuem prestações a serem cumpridas (e não há apenas obrigações a cargo de uma única parte). ${ }^{444}$
\end{abstract}

Carvalho Fernandes, por exemplo, observa que no contrato unilateral em benefício do credor, havendo uma alteração nas circunstâncias com o agravamento da prestação, o devedor poderá reagir contra ela. Entretanto, o credor, segundo este autor, não teria interesse em rescindir o contrato, "pois melhor será receber pouco que nada", a não ser naqueles casos em que o objeto da prestação, em razão da alteração das circunstâncias, "já não tem qualquer interesse para ele, pelo que se lhe deve reconhecer aquele direito, o que, aliás, não representa qualquer ofensa do direito, ou do interesse, da outra parte". ${ }^{445}$ É o que sucede na doação, por exemplo.

Luiz Philipe Tavares de Azevedo Cardoso admite a possibilidade de revisão dos contratos gratuitos, mas exclui a aplicação da onerosidade excessiva, admitindo formas subsidiárias de proteção do devedor em caso de alteração das circunstâncias, como a boa-fé objetiva. Segundo este autor, baseado no pensamento do italiano Augusto Pino, os contratos

\footnotetext{
${ }^{443}$ SCHUNCK, Giuliana Bonanno. A onerosidade excessiva superveniente no Código Civil: críticas e questões controvertidas. São Paulo: LTR, 2010. p. 110.

${ }^{444}$ Ibid., p. 111.

${ }^{445}$ CARVALHO FERNANDES, Luís A. A teoria da imprevisão no Direito Civil português. Lisboa: Quid Juris?, 2001. p. 119.
} 
gratuitos podem tornar-se mais gravosos com relação à potencialidade econômica do devedor, mas não podem tornar-se excessivamente onerosos, segundo o artigo 1.467 do Código Civil italiano. $^{446}$

Também Alfredo José Rodrigues Rocha de Gouveia coloca:

Se é possível atacar a rigidez do vínculo contratual aquele que paga muito para receber pouco, deve, por maioria de razão, poder fazê-lo aquele que paga demais (em relação ao momento da convenção) sem nada receber. Assim, nos contratos gratuitos deve o devedor poder reagir contra a excessiva onerosidade superveniente da prestação, devendo, por seu lado, o credor contentar-se com ela diminuída, se esse for o efeito da superveniência uma vez que nada paga. ${ }^{477}$

Nelly Potter, entretanto, sustenta a possibilidade de revisão proposta pelo próprio credor da obrigação gratuita, com o seguinte exemplo:

\begin{abstract}
Imagine-se uma senhora viúva, a quem a empresa em que seu marido laborou a vida, ofertou, após o falecimento deste, à título de reconhecimento pelos grandes préstimos de seu cônjuge, uma confortável pensão vitalícia, com a qual a senhora poderia garantir sua moradia, seus remédios, plano de saúde e demais despesas de subsistência. Ora, em ocorrido no país uma grave mudança na economia, que torne risível o valor por ela auferido, que flagrante injustiça seria negar-lhe o direito de pedir revisão do pactuado, malgrado recebesse o dito benefício a título unilateral e gratuito. ${ }^{448}$
\end{abstract}

Outro questionamento que pode advir do artigo 480 está em que o dispositivo não menciona a possibilidade de resolução do contrato, mas apenas a sua modificação.

O Código Civil peruano, de forma semelhante ao brasileiro, prevê em seu artigo 1442 que "Cuando se trate de contratos en que una sola de las partes hubiera asumido obligaciones, le es privativo solicitar judicialmente la reducción de la prestación a fin de que cese su excesiva onerosidad".

\title{
5.6 A APLICAÇÃo DO ARTIGO 317 DO CÓDIGO CIVIL
}

Já citado anteriormente, o artigo 317 do Código Civil prevê: "Quando, por motivos imprevisíveis, sobrevier desproporção manifesta entre o valor da prestação devida e o do

\footnotetext{
446 CARDOSO, Luiz Philipe Tavares de Azevedo. A onerosidade excessiva no Direito Civil Brasileiro. Dissertação (Mestrado) - Universidade de São Paulo, São Paulo, 2010. p. 138.

${ }^{447}$ ROCHA DE GOUVEIA, Alfredo José Rodrigues. Da teoria da imprevisão nos contratos civis. Lisboa: FDUL, 1958. p. 41.

448 POTTER, Nelly. Revisão e resolução dos contratos no Código Civil conforme perspectiva CivilConstitucional. Rio de Janeiro: Lumen Juris, 2009. p. 183.
} 
momento de sua execução, poderá o juiz corrigi-lo, a pedido da parte, de modo que assegure, quanto possível, o valor real da prestação". Não se trata, portanto, de uma desproporção entre prestação e contraprestação, conforme afirma Laura Coradini Frantz. ${ }^{449}$

Segundo esta autora, o escopo do artigo 317 é a solução para a desproporção de prestações pecuniárias, quando o fato que causou tal desproporção estiver relacionado às vicissitudes apresentadas pela própria moeda, caso da inflação e da superveniente valorização da prestação pecuniária. ${ }^{450}$

Como já citado, o referido artigo encontra-se na Seção III (Do objeto do pagamento e sua prova), do Capítulo I (Do Pagamento), do Título III (Do adimplemento e extinção das obrigações), portanto, até mesmo em razão de sua localização sistemática, verifica-se que o dispositivo possa ser aplicado às obrigações em geral e não apenas aos contratos como se infere dos artigos 478 a 480 do Código Civil.

Grande parte da doutrina brasileira afirma que o artigo aplica-se às obrigações pecuniárias $^{451}$.

Renan Lotufo ${ }^{452}$, entretanto, afirma que este posicionamento “merece reparos":

A presente disposição, em primeiro lugar, não se restringe às questões contratuais, em que, pelo princípio da justiça contratual, o equilíbrio das prestações deve ser mantido, como decorrência da eqüitatividade, igualdade. Por outro lado, por ter aplicação mais ampla (a toda e qualquer obrigação), não colide nem invalida as disposições expressas relativas à onerosidade excessiva, estipuladas para serem de aplicação estrita ao campo contratual.

Giuliana Bonnano Schunck ${ }^{453}$ afirma que o dispositivo aplica-se a diversos tipos e categorias contratuais e que tanto o credor como o devedor podem pleitear a correção do valor da prestação. ${ }^{454}$

É de se ressaltar ainda que o artigo 317 não fez menção a que se trate de um evento "extraordinário", mas apenas exigiu a imprevisibilidade, ao contrário do que dispõe o já analisado artigo 478. Também contrariando a redação do artigo 478, o artigo 317 não exige

${ }^{449}$ FRANTZ, Laura Coradini. Revisão dos contratos: elementos para sua construção dogmática. São Paulo: Saraiva, 2007. p. 110.

${ }^{450}$ Ibid., p. 111.

${ }^{451}$ Nesse sentido é o posicionamento de Luiz Philipe Tavares de Azevedo Cardoso (A onerosidade excessiva no Direito Civil Brasileiro. Dissertação (Mestrado) - Universidade de São Paulo, São Paulo, 2010. p. 145) e Laura Coradini Frantz (Revisão dos contratos: elementos para sua construção dogmática. São Paulo: Saraiva, 2007. p. 140).

${ }^{452}$ LOTUFO, Renan. Código Civil Comentado. São Paulo: Saraiva. Vol. 2, 2003. p. 228.

${ }^{453}$ SCHUNCK, Giuliana Bonanno. A onerosidade excessiva superveniente no Código Civil: críticas e questões controvertidas. São Paulo: LTR, 2010. p. 124.

${ }^{454}$ Certique-se que a redação do art. 317 faz menção ao "pedido da parte", sem especificar se se trata do credor ou do devedor. Com esta redação, entende-se que tanto um quanto o outro podem se valer do dispositivo. 
que haja uma extrema vantagem para a parte contrária, prevendo apenas a “desproporcionalidade entre o valor da prestação no momento da celebração e o momento da execução". 455

Nos mesmos moldes do já exposto relativamente ao artigo 478, a exigência da imprevisibilidade do evento é alvo de críticas na doutrina. Nesse sentido, Schunck ${ }^{456}$ afirma:

\begin{abstract}
Não obstante, a redação do artigo merece crítica no que toca ao requisito de motivos imprevisíveis. Como já mencionamos anteriormente, o apego do legislador pátrio à imprevisão - deixando de lado noções mais interessantes, como a quebra da base objetiva do negócio jurídico - pode vir a prejudicar os contratantes que precisem invocar a onerosidade excessiva, sem que tenha necessariamente ocorrido fatos imprevisíveis.
\end{abstract}

Outra ponderação importante está na persistência da possibilidade de revisão contratual das obrigações pecuniárias ainda que haja a estipulação de correção monetária. ${ }^{457}$

\title{
5.7 A DEMANDA REVISIONISTA
}

Havendo alteração nas circunstâncias que tornem o contrato excessivamente oneroso para uma das partes, elas poderão, evidentemente, de forma amigável, firmar uma composição. Não havendo acordo entre elas, a parte prejudicada poderá invocar a alteração das circunstâncias judicialmente, pois a alteração não se opera ipso jure, ressaltando-se que, se a parte que pode se valer da revisão/resolução, ainda assim cumpre a obrigação, não poderá invocar a disciplina dada ao problema. ${ }^{458}$ Não há, portanto, "um efeito liberatório automático", como ensina Giuliana Bonanno Schunck, de forma que "Não é pelo simples fato de a parte entender que há onerosidade excessiva que ela estaria liberada de cumprir sua obrigação contratual, nem mesmo pelo fato de ela ajuizar ação nesse sentido que estaria autorizada a suspender suas prestações". ${ }^{459}$

Na petição inicial da demanda, o autor deverá, evidentemente, narrar os fatos e fundamentos jurídicos de seu direito, ou seja, deverá demonstrar a superveniência do desequilíbrio contratual e, caso o pedido seja de revisão, deverá abordar os moldes em que a

\footnotetext{
${ }^{455}$ SCHUNCK, Giuliana Bonanno. A onerosidade excessiva superveniente no Código Civil: críticas e questões controvertidas. São Paulo: LTR, 2010. p. 125.

${ }^{456}$ Loc. cit.

457 POTTER, Nelly. Revisão e resolução dos contratos no Código Civil conforme perspectiva CivilConstitucional. Rio de Janeiro: Lumen Juris, 2009. p. 160.

${ }^{458}$ CARVALHO FERNANDES, Luís A. A teoria da imprevisão no Direito Civil português. Lisboa: Quid Juris?, 2001. p. 134.

${ }^{459}$ SCHUNCK, Giuliana Bonanno. Op. cit. p. 126.
} 
revisão ocorrerá, possibilitando elementos determinantes e claros para o juiz efetuar a revisão. Ou seja,

\begin{abstract}
A proposta de revisão - quer venha do autor ou do réu - não pode ser um pedido genérico, para que o juiz entre no mérito da contratação e proponha novas condições contratuais, até mesmo sob pena de ofensa ao art. 286 do Código de Processo Civil, com as consequências da inépcia, nos termos dos arts. 282 e 295 do mesmo Código. O juiz não tem o conhecimento do negócio e a expertise comercial das partes para estabelecer condições comerciais. ${ }^{460}$
\end{abstract}

A parte poderá também formular pedidos sucessivos nos moldes do disposto no artigo 289 do Código de Processo Civil.

Conforme já exposto, em razão do princípio da conservação dos negócios jurídicos, deve-se dar preferência à medida judicial que objetive a modificação do contrato firmado, ou seja, uma revisão contratual a fim de que se atinja um equilíbrio diante da alteração das circunstâncias, optando-se pela demanda resolutória apenas na hipótese de incapacidade ${ }^{461}$ da revisão em trazer um equilíbrio ao contrato.

Se houver elementos suficientes de que a revisão seja inócua, havendo pedido da parte interessada, o juiz poderá deferir liminar em tutela antecipada autorizando a suspensão do cumprimento da obrigação, desde que presentes os requisitos contemplados no artigo 273 do Código de Processo Civil, quais sejam, existência de prova inequívoca e verossimilhança da alegação, além de fundado receio de dano irreparável ou de difícil reparação.

Em sendo possível a revisão do contrato, mas havendo a propositura de uma ação resolutória, a parte contrária poderá opor-se à resolução oferecendo-se a "modificar equitativamente as condições do contrato", nos moldes do que dispõe o já comentado artigo 479 do Código Civil. Isto porque, como ensina Carvalho Fernandes, a demanda resolutória não pode levar "pura e simplesmente a transferir os prejuízos emergentes da alteração de circunstâncias de um para o outro contraente". ${ }^{462}$ Nesta hipótese, entende-se que, de acordo com o Código de Processo Civil vigente, o réu deverá valer-se da reconvenção, ressaltandose, que na redação original do Projeto de Lei do Senado n. 166, de 2010, que objetiva reformar o Código de Processo Civil, o artigo 337 prevê a possibilidade de formulação de pedido contraposto na própria contestação, independentemente de ser o rito comum ordinário

\footnotetext{
${ }^{460}$ SCHUNCK, Giuliana Bonanno. A onerosidade excessiva superveniente no Código Civil: críticas e questões controvertidas. São Paulo: LTR, 2010. p. 132.

${ }^{461}$ CARVALHO FERNANDES, Luís A. A teoria da imprevisão no Direito Civil português. Lisboa: Quid Juris?, 2001. p. 134.

${ }^{462}$ Ibid., p. 133.
} 
ou sumário, conforme segue:

Art. 337. É lícito ao réu, na contestação, formular pedido contraposto para manifestar pretensão própria, conexa com a ação principal ou com o fundamento da defesa, hipótese em que o autor será intimado, na pessoa de seu advogado, para responder a ele no prazo de quinze dias.

Parágrafo único. A desistência da ação ou a ocorrência de causa extintiva não obsta ao prosseguimento do processo quanto ao pedido contraposto.

Por outro lado, no sistema atual, havendo pedido única e exclusivamente de resolução, logo, sem pedido ainda que subsidiário de revisão, e não havendo oposição da parte contrária por intermédio da reconvenção que vise à modificação, mas apenas contestação quanto ao preenchimento dos requisitos de direito material para a resolução, ao juiz não restará outra alternativa que não seja o julgamento de procedência do pedido se estiverem preenchidos os requisitos do direito material invocado pelo autor ou o julgamento de improcedência se tais requisitos não forem preenchidos. O que o juiz não poderá, segundo Carvalho Fernandes é, "substituindo-se à vontade das partes, decretar, ex officio, a modificação, se só a resolução tiver sido pedida e a parte contrária lhe não opuser a modificação. Daqui decorre que, a não ser viável a resolução pedida, o juiz terá que emitir uma decisão no sentido da manutenção do negócio, tal como foi celebrado". ${ }^{463}$

No mesmo sentido, Nelly Potter afirma que a decisão do juiz "fica adstrita a verificar a existência ou não da onerosidade excessiva, para assim resolver o pacto com base no pedido autoral, ou mantê-lo, dando ganho de causa ao credor". ${ }^{464}$ Com este posicionamento concorda Giuliana Bonnano Schunck, afirmando que o juiz não pode obrigar a que ocorra a revisão e que ele não poderá "adentrar na formulação de novas condições contratuais, podendo, quando muito, integrar minimamente a proposta de revisão, para que ela possa ser viável". ${ }^{465}$

Entretanto, Nelson Borges ${ }^{466}$ afirma que esta solução não parece justa às partes, aventando a seguinte hipótese:

Suponha-se um credor demandado em vultoso contrato parcialmente

${ }^{463}$ CARVALHO FERNANDES, Luís A. A teoria da imprevisão no Direito Civil português. Lisboa: Quid Juris?, 2001. p. 300.

${ }^{464}$ POTTER, Nelly. Revisão e resolução dos contratos no Código Civil conforme perspectiva CivilConstitucional. Rio de Janeiro: Lumen Juris, 2009. p. 192.

${ }^{465}$ Afirma ainda esta autora: "É importante lembrar que o réu pode não concordar com a alteração proposta pelo autor, caso em que o contrato deve ser resolvido, sob pena de obrigar o réu a contratar em bases com as quais ele não concorda, o que não pode ser aceito, sob pena de ferir a autonomia privada". SCHUNCK, Giuliana Bonanno. A onerosidade excessiva superveniente no Código Civil: críticas e questões controvertidas. São Paulo: LTR, 2010. p. 133.

${ }^{466}$ BORGES, Nelson. A teoria da imprevisão no Direito Civil e no Processo Civil. São Paulo: Malheiros, 2002. p. 692-693. 
cumprido pelo devedor e que, ao contestar a ação, por entender ausentes os pressupostos de admissibilidade de aplicação da doutrina da imprevisibilidade, pretenda atacar somente a falta de condições para o exercício da ação e, por entender incabível, deixe de oferecer modificação equitativa nas condições do contrato (proposta de revisão), simplesmente por entender que não se trata de uma situação de imprevisibilidade. Ainda no campo das suposições: a contestação é recebida, e o juiz, discordando do réu, entende que os pressupostos atacados estão presentes, bem como a excessiva onerosidade e extrema vantagem do credor, e, pela ausência de proposta de revisão, acabe por decretar a resolução. A justiça à parte terá sido feita? Parece óbvio que não.

Outra hipótese que se vislumbra está naquela em que o autor formula apenas pedido de revisão a que se oponha o réu, sem que este formule pedido de modificação em reconvenção. Neste caso, Giulianna Bonnano Shcunck, por exemplo, afirma que "o juiz teria que julgar a ação improcedente, pois não poderia obrigar o réu a aceitar a revisão, nem decidir de ofício pela resolução, já que estaria, em tese, decidindo ultra petita". ${ }^{467}$

Deve restar claro que a decisão judicial proferida na ação revisional de um contrato sofrerá limites de forma que não poderá usurpar a vontade das partes alterando o contrato, pois "ninguém melhor do que as próprias partes para fazer juízo de seus sacrifícios, dos valores que lhes dizem respeito", 468

Assim, Giuliana Bonnano Schunck afirma: "Entendemos que a parte que pleiteia a revisão - sendo o autor ou réu - deve dar ao juiz o balizamento para a intervenção judicial. O juiz não pode, sem ter critérios já estabelecidos pela parte, intervir na relação privada para modificar o contrato de acordo com aquilo que ele acredita ser justo". 469

Para Nelly Potter, havendo pedido de resolução por parte do autor e pedido de modificação equitativa por parte do réu através de reconvenção contra a qual o autor se opõe, o juiz poderá modificar o contrato, "afastando assim a resolução". ${ }^{470}$

A ação resolutória ou revisional poderá ser proposta tanto pelo credor quanto pelo devedor, visto que a onerosidade pode atingir a um ou o outro, "senão não se trata de justiça". ${ }^{471}$ Nas palavras de Nelly Potter "Tanto o credor quanto o devedor, em nome do valor bilateral do direito e da justiça, podem valer-se do remédio. Com efeito, seria uma afronta aos valores constitucionais e mesmo à harmonia do ordenamento, tratar de forma diferenciada as

\footnotetext{
${ }^{467}$ SCHUNCK, Giuliana Bonanno. A onerosidade excessiva superveniente no Código Civil: críticas e questões controvertidas. São Paulo: LTR, 2010. p. 136.

${ }^{468}$ MARTINS, Fernando Rodrigues. Princípio da justiça contratual. São Paulo: Saraiva, 2009. p. 367.

${ }^{469}$ SCHUNCK, Giuliana Bonanno. Op. cit., p. 131.

470 POTTER, Nelly. Revisão e resolução dos contratos no Código Civil conforme perspectiva CivilConstitucional. Rio de Janeiro: Lumen Juris, 2009. p. 190.

${ }^{471}$ MARTINS, Fernando Rodrigues. Op. cit., p. 381.
} 
partes de modo geral". 472

Sendo decretada a resolução do contrato, ele deixa de produzir efeitos a partir do momento em que o réu for citado na ação em que a alteração das circunstâncias foi invocada pelo contraente interessado, ${ }^{473}$ não podendo versar sobre prestações já cumpridas, hipótese em que, segundo Carvalho Fernandes, “a segurança do tráfico e os interesses gerais da contratação seriam gravemente afectados, se um contraente, depois de receber as prestações que lhe eram devidas, não pudesse considerá-las definitivamente suas". ${ }^{474}$

Entretanto, a redação do artigo 479, ao prever que os efeitos da sentença que decretar a resolução terá efeitos retroativos à data da citação, merece ser melhor analisada. Isto porque se distinguem os efeitos da sentença proferida relativamente a contrato de execução diferida ou continuada. Na primeira hipótese, os efeitos serão ex tunc, ou seja, retroagirão "como se o negócio nunca tivesse existido, devendo as partes voltar ao status quo ante. Assim, a prestação já cumprida será devolvida e aquela por cumprir não será executada". ${ }^{475} \mathrm{Na}$ segunda hipótese, ou seja, no contrato de execução continuada, as prestações satisfeitas não são atingidas, pois se consideram exauridas, conforme ensina Orlando Gomes. ${ }^{476}, 477$

Por outro lado, havendo revisão do contrato e não resolução, a sentença produzirá efeitos ex nunc, retroagindo até a data da citação.

Carvalho Fernandes questiona se na demanda que objetiva a resolução do contrato é possível ao réu pleitear uma indenização pelos prejuízos sofridos pelo não cumprimento do contrato. $^{478}$

Quanto a isto, em regra, para que se fale em um dever de indenizar, exige-se a prática de um ato ilícito ou descumprimento de uma obrigação contratual, o que não se vislumbra na hipótese, pois não se trata de ato ilícito, mas sim de hipótese contemplada em lei que possibilita a resolução do contrato por alteração das circunstâncias justamente com o objetivo de atendimento ao princípio do equilíbrio contratual.

\footnotetext{
472 POTTER, Nelly. Revisão e resolução dos contratos no Código Civil conforme perspectiva CivilConstitucional. Rio de Janeiro: Lumen Juris, 2009. p. 165.

${ }^{473}$ CARVALHO FERNANDES, Luís A. A teoria da imprevisão no Direito Civil português. Lisboa: Quid Juris?, 2001. p. 142.

474 Ibid., p. 280.

475 SCHUNCK, Giuliana Bonanno. A onerosidade excessiva superveniente no Código Civil: críticas e questões controvertidas. São Paulo: LTR, 2010. p. 130.

${ }^{476}$ GOMES, Orlando. Contratos. Rio de Janeiro: Forense, 2007. p. 219.

${ }^{477}$ No mesmo sentido posiciona-se Nelly Potter. (POTTER, Nelly. Revisão e resolução dos contratos no Código Civil conforme perspectiva Civil-Constitucional. Rio de Janeiro: Lumen Juris, 2009. p. 208).

${ }^{478}$ CARVALHO FERNANDES, Luís A. Op. cit., p. 142.
} 


\subsection{A VALIDAde de CLÁUSUla QUE IMPEÇA A REVISÃo/RESOLUÇÃo ALTERAÇÃo DAS CIRCUNSTÂNCIAS E DA CLÁUSULA DE RENEGOCIAÇÃo}

É possível questionar-se a validade de uma cláusula que impeça a revisão ou resolução do contrato em razão da alteração das circunstâncias que tornem o cumprimento da obrigação excessivamente oneroso para uma das partes, ou seja, tal cláusula "significará que as partes aceitam suportar todas as consequências que para qualquer delas advenham da modificação do condicionalismo existente à data da celebração do contrato". ${ }^{479}$

O Código Civil brasileiro silencia a respeito do tema. Entretanto, se considerarmos que este codex, no artigo 393, permite que o devedor se responsabilize pelos prejuízos resultantes de caso fortuito e força maior, a tendência será consideramos válida uma cláusula impeditiva da revisão. Nesse sentido, em hipótese semelhante, a doutrina portuguesa é enfática:

[...] não se deve esquecer que à face do Direito português são possíveis e válidas cláusulas em que um dos contraentes tome a seu cargo os casos fortuitos e de força maior, princípio de que se pode extrair um argumento de maior razão em favor da admissibilidade do tipo de cláusula a que nos referimos. Em vista disso, parece-nos preferível, pelo menos de jure condito, a doutrina que defende a possibilidade legal de tais cláusulas. ${ }^{400}$

A temática, entretanto, é controversa na doutrina. Othon Sidou e Luiz Philipe Tavares de Azevedo Cardoso ${ }^{481}$ são favoráveis a uma cláusula exoneratória. Sílvio de Salvo Venosa, por outro lado, sustenta que uma cláusula genérica de exoneração cercearia "o direito de ação em geral" e implicaria "uma renúncia prévia genérica a direitos". ${ }^{482}$ Este autor, entretanto, aceita uma cláusula exonerativa que contemple determinados fatos configurativos de excessiva onerosidade. ${ }^{483}$

Segundo Luiz Philipe Tavares de Azevedo Cardoso, a resolução por onerosidade excessiva é um naturalia negotii, um elemento natural do negócio jurídico, ou seja,

\footnotetext{
${ }^{479}$ CARVALHO FERNANDES, Luís A. A teoria da imprevisão no Direito Civil português. Lisboa: Quid Juris?, 2001. p. 99.

${ }^{480}$ Loc. cit.

${ }^{481}$ Segundo o autor, a resolução por onerosidade excessiva é um naturalia negotii, um elemento natural do negócio jurídico, ou seja, "aquele que pode ser afastado pelas partes em que o negócio mude de categoria. Um contrato não deixará de ser qualificado pelo ordenamento jurídico como contrato se as partes tiverem renunciado à possibilidade de revisá-lo. Desse modo, não haveria qualquer problema em se renunciar a esse direito". (CARDOSO, Luiz Philipe Tavares de Azevedo. A onerosidade excessiva no Direito Civil Brasileiro. Dissertação (Mestrado) - Universidade de São Paulo, São Paulo, 2010. p. 155).

${ }^{482}$ VENOSA, Sílvio de Salvo. Direito Civil. Vol. II. São Paulo, Atlas, 2010. p. 482.

${ }^{483}$ No mesmo sentido é o posicionamento de Nelly Potter (POTTER, Nelly. Revisão e resolução dos contratos no Código Civil conforme perspectiva Civil-Constitucional. Rio de Janeiro: Lumen Juris, 2009. p. 211).
} 
[...] aquele que pode ser afastado pelas partes sem que o negócio mude de categoria. Um contrato não deixará de ser qualificado pelo ordenamento jurídico como contrato se as partes tiverem renunciado à possibilidade de revisá-lo. Desse modo, não haveria qualquer problema em se renunciar a esse direito.

Entretanto, escorado em Antônio Junqueira de Azevedo e Renan Lotufo, o referido autor sustenta que a renúncia à resolução ou revisão por onerosidade excessiva deve ser "específica", sob pena de implicar a renúncia antecipada uma "previsão do imprevisível, o que se mostra contraditório do ponto de vista lógico". ${ }^{484}$ Desta forma,

[...] o evento superveniente cujo risco de advir é coberto pela parte, deve estar previsto e especificado, de modo que não pairem dúvidas acerca da impossibilidade de alegar o desequilíbrio por ele causado. Assim, as partes podem prever determinados riscos geológicos, determinados índices de inflação, determinada conjuntura internacional. Quando da ocorrência de determinado fato, ele deverá ser cotejado com o efetivamente previsto, o que faz com que o problema se coloque, assim como na antiga cláusula rebus sic stantibus, como uma questão de interpretação, na qual as particularidades do fato ocorrido deverão ser examinadas. No limite, sempre poderá ocorrer algo de imprevisível. ${ }^{485}$

Em qualquer caso, entretanto, deve-se observar a regra do artigo 114 do Código Civil, interpretando-se a renúncia de forma restritiva.

O Código Civil italiano, em seu artigo $1469^{486}$ admite a inserção de uma cláusula que impeça a revisão por onerosidade excessiva.

No Brasil, entretanto, é possível também que as partes, ao celebrarem o contrato, estabeleçam como irrelevantes determinadas alterações, ou ainda que a modificação do contrato somente possa ocorrer se a alteração das circunstâncias não ultrapassar certo limite, "ficando a resolução reservada para as que vão além dele". ${ }^{487}$

Exemplificativamente, Andrew A. Schwartz ${ }^{488}{ }^{489}$ cita algumas cláusulas que podem

484 CARDOSO, Luiz Philipe Tavares de Azevedo. A onerosidade excessiva no Direito Civil Brasileiro. Dissertação (Mestrado) - Universidade de São Paulo, São Paulo, 2010. p. 155-156.

485 Ibid., p. 156.

486 “As normas dos artigos precedentes não se aplicam aos contratos aleatórios por sua natureza (1879) ou por vontade das partes $(1448,1472)$ ".

${ }^{487}$ CARVALHO FERNANDES, Luís A. A teoria da imprevisão no Direito Civil português. Lisboa: Quid Juris?, 2001. p. 273.

488 SCHWARTZ, Andrew A. A "Standard Clause Analysis" of the Frustration Doctrine and the Material Adverse Change Clause, v. 57, U.C.L.A Law Review, 2010, p. 22.

489 "Alternatively, a Frustration clause might enumerate a list of specific types of events that will serve to excuse a party's performance. This list may be comprised of extraordinary events, or ordinary events, or any other type of events, depending on the wishes of the parties. Most likely, such a clause would look much like a Force 
ser inseridas pelas partes objetivando delimitar a possibilidade de revisão do contrato: que $50 \%$ de desvalorização do objeto no preço de mercado impeça a revisão; estabelecer valores fixos em dinheiro (compra e venda de barris de petróleo por $\$ 50$ em certa data, a não ser que nesta data o barril esteja sendo comercializado abaixo de \$20); determinar quais eventos posteriores possam escusar a performance; estabelecer uma fórmula para calcular eventual restituição de valores.

Para Giuliana Bonnano Schunck, o ideal seria que o contrato explicitasse "os motivos pelos quais apenas uma das partes será privada de invocar a figura da onerosidade excessiva superveniente, para evitar dúvidas sobre a validade da manifestação de vontade das partes". 490

O Superior Tribunal de Justiça tratou de hipótese semelhante ${ }^{491}$. No caso, o dono de um imóvel o cedeu a uma construtora para que nele edificasse um prédio residencial, recebendo, em dação em pagamento, uma unidade e meia de apartamento. A construtora sustentou a necessidade de revisão do contrato originariamente firmado entre as partes, alegando que ele se tornou excessivamente oneroso, pois no momento da sua celebração, as metragens do terreno cedido e das futuras unidades residenciais eram equivalentes. Ocorre que, após a celebração do contrato, foram feitas inúmeras alterações na obra a que a outra parte se recusava a aditar os termos iniciais do contrato, adequando a prestação da construtora à mesma proporção original. O Tribunal de Justiça do Estado de São Paulo já havia decidido que o próprio contrato continha cláusula disciplinando a alteração do projeto e a respectiva valorização dos apartamentos, afirmando:

[...] o contrato nessa cláusula é expresso. Convém transcrever: 'Todas as características, medidas e especificações das unidades condominiais autônomas objeto da dação em pagamento aos intervenientes sub-rogados nos direitos dos OUTORGADOS, assim como os demais apartamentos do Edifício Saint Patrick, poderão sofrer alterações ditadas por razões legais ou técnicas, de compatibilização em decorrência do processo de unificação dos terrenos, onde está sendo erigido o edifício, bem como as constantes dos atos registrários definitivos da incorporação àquele referente. Para todos os

Majeure clause, except that the list would be comprised of extraordinary events that would render counterperformance worthless, rather than those that would render performance impracticable. The usual Force Majeure litany of acts of God, terrorism, unseasonal weather, fires, accidents, breakdowns, strikes, et cetera, all pertain to anomalous events that would make performance burdensome or impossible. By contrast, a Frustration clause would have to enumerate a different sort of list, one comprised of events or changes that would make counterperformance worthless. The list might include events such as a "severe reduction in demand" or "radically changed market conditions". (SCHWARTZ, Andrew A. A "Standard Clause Analysis" of the Frustration Doctrine and the Material Adverse Change Clause, v. 57, U.C.L.A Law Review, 2010, p. 25).

${ }^{490}$ SCHUNCK, Giuliana Bonanno. A onerosidade excessiva superveniente no Código Civil: críticas e questões controvertidas. São Paulo: LTR, 2010. p. 142.

${ }^{491}$ Recurso Especial n. 831.808-SP, 33 Turma, Rel. Min. Nancy Andrighi, j. 18.05.2006. 
efeitos, não haverá torna ou reposição por parte dos OUTORGADOS ou dos INTERVENIENTES, mesmo que as áreas das unidades a serem entregues sejam substancialmente maiores do que está ajustado, sendo certo que na composição do valor do preço foram levados em consideração todos os fatores que poderão influir na comparação entre o valor das unidades objeto da dação e o valor dos terrenos, de tal sorte que, qualquer apuração do custo final da construção que venha a alterar o valor atribuído em termos nominais ou reais, não autorizará qualquer alteração da área das unidades a serem entregues aos INTERVENIENTES, salvo para entrega a maior sem custo adicional e tão pouco implicará qualquer exigência de pagamento por parte dos INTERVENIENTES.

Com isto, o STJ excluiu a possibilidade de revisão contratual "pois descaracterizada a alegada onerosidade excessiva da prestação devida pela construtora, ora recorrente".

Há, por outro lado, a possibilidade de inserção no contrato de uma cláusula de renegociação a qual impõe às partes "a obrigação de renegociar um contrato sempre que, por efeito de uma alteração das circunstâncias vigentes ao tempo da sua celebração, se verifica uma modificação substancial do equilíbrio das posições das partes, por estas estabelecido". 492 Assim, as próprias partes, em razão do princípio da autonomia da vontade, ao celebrarem o contrato, podem, desde logo estipular as consequências do contrato, "no caso de sobrevirem circunstâncias de certo tipo" do negócio que celebram, nomeadamente mediante a estipulação de cláusulas que o ponham a cargo de uma delas, no todo ou em parte". ${ }^{494}$

Nas palavras de Frederico Eduardo Zenedin Glitz, esta cláusula, chamada de hardship, tem a seguinte prerrogativa:

[...] permitiria que os contratantes estabelecessem quais seriam os eventos que caracterizariam sua incidência, podendo, inclusive, excluir expressamente alguns. Permitiria, ainda, estabelecer-se detalhadamente a constatação do evento e os procedimentos para a revisão. Os critérios da imprevisibilidade e da inevitabilidade poderiam ser acrescidos ou diminuídos. Enfim, este tipo de cláusula permitiria grande margem de atuação das partes visando-se à manutenção do vínculo contratual”. Segundo o autor, a recusa a negociar representaria uma violação do contrato, passível de condenação por perdas e danos e que esta cláusula surge como "instrumento de manutenção do equilíbrio contratual e, por conseqüência, de sua funcionalização. Sua oportunidade adviria, justamente, da possibilidade de atribuir às próprias partes a solução de um conflito negocial (acerca de

\footnotetext{
${ }^{492}$ CARVALHO FERNANDES, Luís A. A teoria da imprevisão no Direito Civil português. Lisboa: Quid Juris?, 2001. p. 316.

${ }^{493}$ Iturraspe e Piedcasas exemplificam: novos custos fiscais, restrições derivadas de novas políticas ambientais, variações nas taxas de câmbio, condições impostas à importação ou exportação etc. (ITURRASPE, Jorge Mosset; PIEDECASAS, Miguel A. La revisión del contrato. Santa Fe: Rubinzal Culzoni, 2008. p. 384).

${ }^{494}$ CARVALHO FERNANDES, Luís A. Op. cit., p. 273.
} 
seu equilíbrio), de modo a atender as respectivas necessidades e expectativas. A parceria oriunda do esforço mútuo dos contratantes para viabilizar seu negócio, adequando-o às novas circunstâncias, talvez revelasse uma nova forma de justiça social, mais participativa e, por conseqüência, mais próxima da realidade contemporânea. ${ }^{495}$

O chamado à renegociação deve ser feito por intermédio de notificação, sendo que, havendo recusa da parte contrária, o prejudicado poderá socorrer-se do Poder Judiciário.

Iturraspe e Piedecasas afirmam que a renegociação é um ótimo caminho porque: i) deixa a superação do conflito nas mãos das próprias partes, donas do negócio; ii) evita a instância judicial que é custosa e de resultado inseguro; iii) não incorpora um "terceiro" ao debate, como é o caso do magistrado, com os riscos lógicos do desconhecimento do negócio discutido; iv) a renegociação põe à prova a solidariedade e equidade dos celebrantes; v) deve estar presidida pela ideia do "sacrifício repartido", da utilidade com justiça, da manutenção da relação negocial. ${ }^{496}$

O artigo 6.2.3 $3^{497}$ dos Princípios de Direito Contratual Europeu prevê que, em caso de onerosidade excessiva a parte em desvantagem "pode reclamar a renegociação do contrato". O artigo dispõe também que tal reclamo deve ser feito "sem demora injustificada", com indicação dos fundamentos em que se baseia.

Cláudia Lima Marques afirma que a doutrina alemã vem estudando a existência de um dever geral de renegociação nos contratos de longa duração, partindo da premissa de que haveria uma cláusula ou um dever de modificação de boa-fé dos contratos de longa duração, sempre que exista quebra da base objetiva do negócio e onerosidade excessiva daí resultante. A referida doutrina considera que haveria "uma espécie de dever ipso jure de adaptação (ipso jure-Anpassungspflicht) ou dever de antecipar e cooperar na adaptação, logo dever (ou, para

\footnotetext{
495 ZENEDIN GLITZ, Frederico Eduardo. Contrato e sua conservação: lesão e cláusula de hardship. Curitiba: Juruá, 2008. p. 167-178.

${ }^{496}$ ITURRASPE, Jorge Mosset; PIEDECASAS, Miguel A. La revisión del contrato. Santa Fe: Rubinzal Culzoni, 2008. p. 451.

${ }^{497}$ No original: Artículo 6.2.3 (Efectos de "excesiva onerosidad" (hardship)

(1) En caso de "excesiva onerosidad" (hardship), la parte en desventaja puede reclamar la renegociación de contrato. Tal reclamo deberá formularse sin demora injustificada, con indicación de los fundamentos en los que se basa.

(2) El reclamo de renegociación no autoriza por sí mismo a la parte en desventaja para suspender el cumplimiento.

(3) En caso de no llegarse a un acuerdo dentro de un tiempo prudencial, cualquiera de las partes puede acudir a un tribunal.

(4) Si el tribunal determina que se presenta una situación de "excesiva onerosidad" (hardship), y simpre que lo considere razonable, podrá:

(a) resolver el contrato en fecha y condiciones a ser fijadas; $o$

(b) adaptar el contrato con miras a restablecer su equilibrio.
} 
alguns, Obligenheit) de renegociar (Neuverhandlungspflicht) o contrato". ${ }^{498}$

Sobre a cláusula de renegociação, Pablo Salvador Coderch $^{499}$ afirma que a sua imposição carece de sentido, afirmando que a renegociação do contrato é, como o próprio contrato, voluntária.

É de se indagar sobre a possibilidade de inclusão de cláusula que permita a revisão por alteração das circunstâncias em razão de uma condição subjetiva das partes. Pense-se na chamada moral clause ou "cláusula moral" conhecida no direito norte-americano e muito frequente em contratos publicitários firmados por atores, atletas profissionais e outras celebridades para endossar uma marca ou produto. ${ }^{500}$ Nestes contratos, uma empresa ou marca entrelaça a sua imagem com a de uma celebridade, mas se ela comete um crime ou um ato moralmente reprovável, ou de qualquer forma seja envolvida em um escândalo que possa abalar a imagem da empresa, passando uma imagem que não lhe convém, é possível a resolução do contrato.

Exemplificativamente, é o caso da modelo inglesa Kate Moss que teve fotografias publicadas em todo o mundo em que consumia cocaína. Na época, a modelo mantinha contratos publicitários milionários com marcas como Chanel e Burberry. Outro exemplo foi o golfista Tiger Woods envolvido em vários escândalos sexuais enquanto casado com a modelo Elin Nordegren. Por fim, cita-se o nadador americano Michael Phelps, várias vezes campeão olímpico, que se envolveu em um escândalo ao ser fotografado fumando maconha.

Segundo Andrew A. Schwartz ${ }^{501}$, a cláusula moral geralmente menciona tipos de conduta que legitimarão a empresa a resolver o contrato. Entretanto, em razão da autonomia negocial, as próprias partes podem estipular que a resolução do contrato se dará pelo mero indiciamento de um crime ou se será necessária a condenação em primeira instância ou o seu trânsito em julgado. Podem também estipular se será qualquer crime que ensejará a resolução ou apenas um ou outro tipo específico.

Outra cláusula que poderá ser estipulada é a chamada walkaway clause que consiste em uma cláusula utilizada em contratos de financiamento de automóveis permitindo ao comprador cessar os pagamentos periódicos e devolver o veículo no caso de uma alteração em sua vida pessoal, tal como desemprego (involuntário) e perda da habilitação para dirigir

\footnotetext{
${ }^{498}$ MARQUES, Cláudia Lima. Contratos no Código de Defesa do Consumidor. São Paulo: RT, 2002. p. 293.

${ }^{499}$ CODERCH, Pablo Salvador. Alteración de circunstancias en el art. 1213 de la Propuesta de Modernización del Código Civil en materia de Obligaciones y Contratos. Revista para el Análisis del Derecho, Barcelona, Octubre de 2009, p. 47. (Disponível em: <http://ssrn.com/abstract=1495082〉. Acesso em: 03 abr. 2012).

500 SCHWARTZ, Andrew A. A "Standard Clause Analysis" of the Frustration Doctrine and the Material Adverse Change Clause, v. 57, U.C.L.A Law Review, 2010, p. 28-31.

${ }^{501}$ Ibid., p. 31.
} 
(desde que não seja decorrente de direção sob a influência de álcool). É evidente que uma cláusula como esta tem um custo que será embutido no preço do financiamento ou separadamente, por intermédio de uma seguradora. ${ }^{502}$

Muito utilizada também nos Estados Unidos da América é a MAC clause ou material adverse change clause que é utilizada em fusão de empresas. Normalmente, as fusões envolvendo grandes empresas é um longo procedimento que pode durar meses ou até mais de um ano dependendo da complexidade do negócio, da necessidade de aprovação dos órgãos reguladores (ex. Conselho Administrativo de Defesa Econômica - CADE), desde o momento em que as partes firmam o acordo de fusão e até o momento em que esta realmente aconteça. Não obstante as previsões de um das partes com relação às receitas e lucros da outra, é evidente que eventos imprevisíveis posteriores ao acordo podem alterar a qualidade do negócio até que a fusão aconteça. ${ }^{503}$ Andrew A. Schwartz lembra o caso do Bank of America que concordou em adquirir o Merrill Lynch em setembro de 2008, por U\$50 bilhões, o que à época foi considerado como razoável. Entretanto, é sabido que, na sequência, uma quebra na economia americana em outubro daquele mesmo ano, quando então o contrato estava para ser fechado, Merrill Lynch "provavelmente valia menos que zero". É caso pertinente à MAC clause que atua como uma condição para a obrigação do adquirente de fechar o acordo, autorizando-o a não fechá-lo se a empresa adquirida sofrer uma mudança material adversa, frustrando uma aquisição lucrativa e sinérgica. ${ }^{504}$

Ainda segundo Schwartz, esta cláusula tomou maior importância com o crash das empresas digitais, os ataques de 11 de setembro de 2001, fraudes nas empresas Enron e Worldcom, a bolha imobiliária e a pior recessão desde a Grande Depressão de 1929.

Outro aspecto interessante e que pode ser aplicado no Brasil em razão do princípio processual da causalidade está na solução adotada pelo artigo $68^{505}$ das Federal Rules of Civil

502 SCHWARTZ, Andrew A. A "Standard Clause Analysis" of the Frustration Doctrine and the Material Adverse Change Clause, v. 57, U.C.L.A Law Review, 2010, p. 32-33.

503 Ibid., p. 35.

${ }^{504}$ Ibid., p. 39.

${ }^{505}$ No original: Rule 68. Offer of judgment.

(a) MAKING AN OFFER; JUDGMENT ON AN ACCEPTED OFFER. At least 14 days before the date set for trial, a party defending against a claim may serve on an opposing party an offer to allow judgment on specified terms, with the costs then accrued. If, within 14 days after being served, the opposing party serves written notice accepting the offer, either party may then file the offer and notice of acceptance, plus proof of service. The clerk must then enter judgment.

(b) UNACCEPTED OFFER. An unaccepted offer is considered withdrawn, but it does not preclude a later offer. Evidence of an unaccepted offer is not admissible except in a proceeding to determine costs.

(c) OFFER AFTER LIABILITY IS DETERMINED. When one party's liability to another has been determined but the extent of liability remains to be determined by further proceedings, the party held liable may make an offer of judgment. It must be served within a reasonable time-but at least 14 days-before the date set for a hearing to determine the extent of liability. 
Procedure do direito americano e que prevê que, se uma das partes em litígio recusa a oferta de transação prévia formulada pela outra, mas que depois obtém por sentença um resultado menos favorável que o derivado da transação, deverá pagar as custas judiciais. ${ }^{506}$

Encerrada a análise da alteração das circunstâncias no Direito Civil, passa-se a analisá-la sob o ótica do Direito do Consumidor.

(d) PAYING COSTS AFTER AN UNACCEPTED OFFER. If the judgment that the offeree finally obtains is not more favorable than the unaccepted offer, the offeree must pay the costs incurred after the offer was made.

${ }^{506}$ CODERCH, Pablo Salvador. Alteración de circunstancias en el art. 1213 de la Propuesta de Modernización del Código Civil en materia de Obligaciones y Contratos. Revista para el Análisis del Derecho, Barcelona, Octubre de 2009, p. 48. (Disponível em: http://ssrn.com/abstract=1495082. Acesso em: 03 abr. 2012). 


\section{CAPÍTULO VI}

\section{O EQUILÍBRIO CONTRATUAL NO CÓDIGO DE DEFESA DO CONSUMIDOR E O CONFRONTO COM O CÓDIGO CIVIL}

\subsection{GENERALIDADES SOBRE O DIREITO DO CONSUMIDOR}

A Lei 8.078 de 1990 institui o Código de Defesa do Consumidor, atendendo a um mandamento da Constituição Federal brasileira, que no artigo 48 do Ato das Disposições Transitórias determinou a elaboração do codex em 180 dias, contados da promulgação da Constituição.

$\mathrm{O}$ artigo $5^{\circ}$, inciso XXXII, da Constituição Federal prevê como direito fundamental a promoção, pelo Estado, da defesa do consumidor na forma da lei ${ }^{507}$. Nos dizeres de Bruno Miragem, a Constituição "assinala o dever do Estado de promover a proteção, indicando a decisão de como realizá-la ao legislador ordinário". 508 Além disso, no artigo 170, inciso V, a defesa do consumidor é considerada um princípio inerente à atividade econômica.

A entrada em vigor do Código de Defesa do Consumidor, fundado nos preceitos solidaristas da Constituição Federal, alterou de forma significativa a teoria contratual, até então individualista, liberal e atrelada à autonomia da vontade e à obrigatoriedade dos contratos.

A partir do momento em que se tornou perceptível a diferença existente entre consumidor e fornecedor, tornou-se necessária a intervenção do Estado a fim de que o consumidor - considerado como a parte vulnerável ${ }^{509}$, mais fraca da relação contratual, do ponto de vista econômico, técnico e jurídico - fosse protegido.

O "direito tradicional", expressão utilizada por João Calvão da Silva, mostrava-se inadequado para atender a relação entre consumidor e fornecedor, considerados "de desigual

\footnotetext{
507 Segundo Cláudia Lima Marques, "O fato de que um dos sujeitos da relação contratual ter recebido direitos fundamentais, quando ocupa o papel de consumidor, influencia diretamente a interpretação da relação contratual em que este sujeito está. O contrato de consumo passa a ser um ponto de encontro de direitos individuais, sendo que os direitos dos consumidores stricto sensu, em especial, das pessoas físicas, são direitos da mais alta hierarquia constitucional, direitos fundamentais, protegidos por cláusula pétrea (art. 60 da CF)"'. MARQUES, Cláudia Lima. Contratos no Código de Defesa do Consumidor. São Paulo: RT, 2002. p. 260.

${ }^{508}$ MIRAGEM, Bruno. Direito do Consumidor. São Paulo: Revista dos Tribunais, 2008. p. 36.

509 Sobre a vulnerabilidade do consumidor, José Geraldo Brito Filomeno ensina: "No âmbito da tutela especial do consumidor, efetivamente, é ele sem dúvida a parte mais fraca, vulnerável, se se tiver em conta que os detentores dos meios de produção é que detêm todo o controle do mercado, ou seja, sobre o que produzir, como produzir e para quem produzir, sem falar-se na fixação de suas margens de lucro". FILOMENO, José Geraldo Brito. Código de Defesa do Consumidor Comentado pelos Autores do Anteprojeto. 7. ed. Rio de Janeiro: Forense Universitária, 2001. p. 55.
} 
estatuto econômico, social, cultural, formativo e informativo". ${ }^{510}$ Com isto, uma legislação consumerista mostrava-se imperiosa, afirmando a doutrina que a necessidade de proteção do consumidor encontra sua origem no princípio máximo da dignidade da pessoa humana. ${ }^{511}$

Nas palavras de Rogério Ferraz Donnini, com o advento do Código de Defesa do Consumidor, a autonomia da vontade "passou a ser limitada e vigiada, para evitar os constantes abusos da parte economicamente mais forte da relação de consumo, ou seja, o fornecedor". Ou ainda, com Cláudia Lima Marques, ao afirmar que "O CDC se propõe a restringir e regular, através de normas imperativas, o espaço antes reservado totalmente para a autonomia da vontade, instituindo como valor máximo a equidade contratual". 512

A desigualdade entre as partes na relação de consumo é cristalina diante da vulnerabilidade do consumidor, sujeito a contratos de adesão, de massa, a cláusulas abusivas e técnicas agressivas de comercialização de produtos e serviços.

Como ensina João Calvão da Silva ${ }^{513}$, com o

\begin{abstract}
Crescimento e concentração de empresas, proliferação de serviços e de produtos complexos e sofisticados, por publicidade e propaganda e outros meios de assédio e apelo ao consumidor, enfim, época de desenvolvimento econômico esplendoroso e de consumo de massa que alguns chamaram mesmo de sociedade de consumo - instala-se um acentuado desequilíbrio ou desigualdade de forças entre produtores e distribuidores, por um lado, e consumidores, por outro, que faz sentir a necessidade da defesa dos mais fracos contra os mais poderosos, dos menos informados contra os mais informados. Por isso começou a ser um imperativo a protecção do consumidor, não só contra a fraude e a desonestidade nas trocas comerciais, não só contra opressões e abusos do poder econômico, mas também contra as contínuas solicitações e "agressões" de que é alvo e, até, contra as suas próprias fraquezas.
\end{abstract}

Vale lembrar o conceito de consumidor contido no artigo $2^{\circ}$ do Código de Defesa do Consumidor, o qual prevê que "consumidor é toda pessoa física ou jurídica que adquire ou utiliza produtos ou serviços como destinatário final”. Este artigo gerou inúmeras interpretações, algumas mais restritivas, outras mais abrangentes. A teoria finalista vincula o conceito de consumidor “à posição de vulnerabilidade, a sugerir sua interpretação restritiva, adquire o produto ou serviço para uso próprio ou de sua família, seria o não profissional". 514

\footnotetext{
${ }^{510}$ CALVÃO DA SILVA, João. Responsabilidade Civil do Produtor. Coimbra: Almedina. 1999, p. 37.

${ }_{511}$ MARQUES, Cláudia Lima. Contratos no Código de Defesa do Consumidor. São Paulo: RT, 2002. p. 260.

${ }^{512}$ Ibid., p. 162.

${ }^{513}$ CALVÃO DA SILVA, João. Op. cit., p. 29-30.

${ }^{514}$ MARQUES, Cláudia Lima. Op. cit. p. 305.
} 
A teoria maximalista, no extremo oposto, interpreta de forma extensiva o conceito de consumidor, enxergando nas normas do Código de Defesa do Consumidor

[...] o novo regulamento do mercado de consumo brasileiro, e não normas orientadas para proteger somente o consumidor não profissional. O CDC seria um Código Geral sobre o consumo, um Código para a sociedade de consumo, que institui normas e princípios para todos os agentes do mercado, os quais podem assumir os papéis ora de fornecedores, ora de consumidores. ${ }^{515}$

Para esta teoria, destinatário final do produto seria aquele que retira o produto do mercado e o utiliza, ainda que seja na produção de algo novo, como, por exemplo, a fábrica de toalhas que compra algodão para transformar. ${ }^{516}$

Já a teoria finalista aprofundada, como o próprio nome diz, é um aprofundamento da teoria finalista. Ela vem sendo aceita pelo Superior Tribunal de Justiça ${ }^{517}$ e

[...] admite, excepcionalmente, desde que demonstrada, in concreto, a vulnerabilidade técnica, jurídica ou econômica, a aplicação das normas do CDC. Quer dizer, não se deixa de perquirir acerca do uso, profissional ou não, do bem ou serviço; apenas, como exceção e à vista da hipossuficiência concreta de determinado adquirente ou utente, não obstante seja um profissional, passa-se a considerá-lo consumidor. ${ }^{518}$

\footnotetext{
${ }^{515}$ MARQUES, Cláudia Lima. Contratos no Código de Defesa do Consumidor. São Paulo: RT, 2002. p. 306. ${ }^{516}$ Loc. cit.

517 ADMINISTRATIVO. ENERGIA ELÉTRICA. REPETIÇÃO DO INDÉBITO. FALTA DE PREQUESTIONAMENTO. INCIDÊNCIA DA SÚMULA N. 211/STJ. ANEEL. AUSÊNCIA DE LEGITIMIDADE. PRESCRIÇÃO. INOCORRÊNCIA. APLICAÇÃO DO CÓDIGO DE DEFESA DO CONSUMIDOR. ESTABELECIMENTO INDUSTRIAL. 1. Os órgãos julgadores não estão obrigados a examinar todas as teses levantadas pelo jurisdicionado durante um processo judicial, bastando que as decisões proferidas estejam devida e coerentemente fundamentadas, em obediência ao que determina o art. 93, inc. IX, da Constituição da República vigente. Isto não caracteriza ofensa ao art. 535 do CPC. Precedentes. 2. A leitura atenta do acórdão combatido, integrado pelo pronunciamento da origem em embargos de declaração, revela que os arts. 42 da Lei n. 8.078/90 e 333, inc. I, do CPC , bem como as teses a eles vinculadas, não foram objeto de debate pela instância ordinária, o que atrai a aplicação da Súmula n. 211 desta Corte Superior, inviabilizando o conhecimento do especial no ponto por ausência de prequestionamento. 3. Esta Corte adota a teoria finalista para o conceito de consumidor, com o abrandamento desta teoria na medida em que admite a aplicação das normas do CDC a determinados consumidores profissionais, desde que seja demonstrada a vulnerabilidade técnica, jurídica ou econômica. Precedentes. 4. Não assiste razão à recorrente, pois a jurisprudência de ambas as Turmas da Seção consolidou-se no sentido de que a União e a ANEEL não detêm legitimidade nas ações em que se discute a restituição de indébito decorrente da majoração ilegal das tarifas de energia elétrica. Precedentes. 5. Em quinto e último lugar, a Primeira Seção, no julgamento do REsp 1.113.403/RJ, de relatoria do Min. Teori Albino Zavascki (DJe 15.9.2009), submetido ao regime dos recursos repetitivos do art. 543-C do Código de Processo Civil e da Resolução STJ n. 8/08, firmou entendimento de que a ação de repetição de indébito de tarifas de água e esgoto, bem como de energia elétrica, sujeitam-se ao prazo prescricional estabelecido no Código Civil. 6. Recurso especial parcialmente conhecido e, nesta parte, não provido. (REsp 1190139/RS, Rel. Ministro MAURO CAMPBELL MARQUES, SEGUNDA TURMA, julgado em 06/12/2011, DJe 13/12/2011).

518 TEPEDINO, Gustavo. Aplicabilidade do Código Civil nas relações de consumo: diálogos entre o Código Civil e o Código de Defesa do Consumidor. In: LOTUFO, Renan; RODRIGUES MARTINS, Fernando (Coord.). 20 anos do Código de Defesa do Consumidor. São Paulo: Saraiva. 2011, p. 75.
} 
Segundo Bruno Miragem, trata-se de um tertium genus entre as correntes finalista e maximalista e que se apresenta a partir de dois critérios básicos: a) que a extensão do conceito de consumidor por equiparação é medida excepcional no CDC; b) é essencial para a extensão conceitual e "por intermédio da equiparação legal (artigo 29), o reconhecimento da vulnerabilidade da parte que pretende ser considerada consumidora equiparada". 519

No outro lado da relação consumerista estaria o fornecedor, contemplado no artigo $3^{\circ}$ do Código de Defesa do Consumidor, que prevê:

[...] fornecedor é toda pessoa física ou jurídica, pública ou privada, nacional ou estrangeira, bem como os entes despersonalizados, que desenvolvem atividades de produção, montagem, criação, construção, transformação, importação, exportação, distribuição ou comercialização de produtos ou prestação de serviços.

Diante da desigualdade existente entre o consumidor e o fornecedor, uma vez definida a relação contratual como consumerista, entendida como "a relação jurídica estabelecida entre consumidor e fornecedor tendo por objeto produto ou prestação de serviço, segundo as conceituações do Código de Defesa do Consumidor brasileiro" ${ }^{\text {, }}$, aplicar-se-á a legislação própria contemplada neste codex, que contém inúmeros dispositivos que revelam a preocupação do legislador com o equilíbrio contratual.

É possível, entretanto, indagar-se quanto à possibilidade de aplicação dos dispositivos relativos ao equilíbrio contratual contidos no Código Civil, considerando-se a unidade do ordenamento jurídico e também que as "bases e fundamentos do direito do consumidor, sua base conceitual, e a lógica em matéria de direito material do consumidor (contratos e responsabilidade civil) tem sua sede no Código Civil". ${ }^{21}$ Além disso, compreende-se a relação de consumo como um negócio jurídico, o que, segundo Giovanni Ettore Nanni, "autoriza a interação entre os conceitos do Direito Civil e o Direito do Consumidor, consoante a situação jurídica concreta". ${ }^{522}$

O Direito do Consumidor não é considerado um

\footnotetext{
${ }^{519}$ MIRAGEM, Bruno. Direito do Consumidor. São Paulo: Revista dos Tribunais, 2008. p. 89.

${ }^{520}$ EFING, Antônio Carlos. Fundamentos do direito das relações de consumo. Curitiba: Juruá, 2011, p. 46.

${ }^{521}$ MIRAGEM, Bruno. Op. cit., p. 29.

522 NANNI, Giovanni Ettore. Relação de consumo: uma situação jurídica em interação entre o Código de Defesa do Consumidor e o Código Civil. In: LOTUFO, Renan; RODRIGUES MARTINS, Fernando (Coord.). 20 anos do Código de Defesa do Consumidor - conquistas, desafios e perspectivas. São Paulo: Saraiva, 2011. p. 140.
} 
[...] direito ex novo, "mas a adaptação e melhoria do direito, sobretudo do tradicional direito das obrigações, designadamente do direito regulador dos contratos, de forma a restabelecer a igualdade das partes rompida pelas mutações sócio-econômicas e a tutelar efectivamente a liberdade contratual e o equilíbrio ou justiça contratual. Em face da desigualdade ou desequilíbrio de forças entre contraentes e sendo o justo e o equilíbrio os próprios fundamentos da força obrigatória dos contratos, o legislador intervém para reequilibrar, moralizar e eticizar os contratos "desestabilizados", restaurando a lealdade, correcção e a confiança das transacções. ${ }^{523}$

Passa-se, então, a abordar o equilíbrio contratual no Código de Defesa do Consumidor.

\subsection{O EQUILÍBRIO CONTRATUAL NO CÓDIGO DE DEFESA DO CONSUMIDOR}

O princípio da obrigatoriedade dos contratos, como já analisado anteriormente, vêse claramente relativizado na atualidade, mormente nas relações consumeristas nas quais se busca o equilíbrio contratual, evitando-se a opressão do mais forte contra o mais fraco.

Segundo Bruno Miragem, o princípio do equilíbrio contratual, ao lado do princípio da vulnerabilidade, revela-se como "resultado do reconhecimento da desigualdade do consumidor nas relações de consumo, e a necessidade de sua proteção pelo direito, cuja finalidade específica será a de garantir o equilíbrio dos interesses entre consumidores e fornecedores". 524

Com o Código de Defesa do Consumidor, o contrato passa a ter o seu equilíbrio, conteúdo ou equidade mais controlados. ${ }^{525}$

Neste diapasão, com vistas à defesa da parte mais fraca, o Código de Defesa do Consumidor traz inúmeros dispositivos que refletem este pensamento, possibilitando, entre outros mecanismos, a modificação do contrato e a nulidade de determinadas cláusulas consideradas abusivas. Seu artigo $4^{\circ}$, que trata dos objetivos da Política Nacional de Relações de Consumo, prevê em seu inciso III o princípio da "harmonização dos interesses dos participantes das relações de consumo e compatibilização da proteção do consumidor com a necessidade de desenvolvimento econômico e tecnológico, de modo a viabilizar os princípios nos quais se funda a ordem econômica (artigo 170 da Constituição Federal), sempre com base na boa-fé e equilíbrio nas relações entre consumidores e fornecedores".

${ }^{523}$ CALVÃO DA SILVA, João. Responsabilidade Civil do Produtor. Coimbra: Almedina. 1999, p. 29-30.
${ }^{524}$ MIRAGEM, Bruno. Direito do Consumidor. São Paulo: Revista dos Tribunais, 2008. p. 76.
${ }^{525}$ MARQUES, Cláudia Lima. Contratos no Código de Defesa do Consumidor. São Paulo: RT, 2002. p. 288. 
$\mathrm{O}$ artigo $6^{\circ}$, inciso $\mathrm{V}$ do Código de Defesa do Consumidor, prevê como direito básico do consumidor "a modificação de cláusulas contratuais que estabeleçam prestações desproporcionais ou sua revisão em razão de fatos supervenientes que as tornem excessivamente onerosas".

A primeira parte do referido inciso trata da hipótese de lesão, ou seja, de um desequilíbrio contratual ocorrido na sua formação (ausência de sinalagma genético). A segunda parte, por sua vez, refere-se ao desequilíbrio superveniente (ausência de sinalagma funcional). O que o Código de Defesa do Consumidor visa é a preservação do contrato de consumo, e não a sua resolução, ${ }^{526}$ atendendo-se, desta forma, ao princípio da conservação dos negócios jurídicos.

Também, o artigo 51, inciso IV, considera como cláusula abusiva aquela que "estabeleça obrigações consideradas iníquas, abusivas, que coloquem o consumidor em desvantagem exagerada, ou sejam incompatíveis com a boa-fé ou a equidade". O mesmo artigo, em seu parágrafo $1^{\circ}$, presume como exagerada a vantagem que "restringe direitos ou obrigações fundamentais inerentes à natureza do contrato, de tal modo a ameaçar seu objeto ou o equilíbrio contratual" (inciso II) e que "se mostra excessivamente onerosa para o consumidor, considerando-se a natureza e conteúdo do contrato, o interesse das partes e outras circunstâncias peculiares ao caso" (inciso III).

Verifica-se, portanto, que o legislador pátrio exteriorizou grande preocupação com o equilíbrio na relação consumerista, em um esforço para evitar as relações espoliativas lideradas pelos fornecedores.

\subsection{O dí́logo ENTRE Código CIVIL E Código DE DEFESA do CONSUMIDOR EM RELAÇÃO À ALTERAÇÃO DAS CIRCUNSTÂNCIAS}

Tanto o Código Civil quanto o Código de Defesa do Consumidor tratam da revisão/resolução dos contratos em razão da alteração das circunstâncias. Tendo em vista que o ordenamento jurídico é único e deve ser analisado de forma sistemática, passa-se a discorrer sobre o diálogo entre os dois sistemas.

\footnotetext{
${ }^{526}$ DONNINI, Rogério Ferraz. A revisão dos contratos no Código Civil e no Código de Defesa do Consumidor. 2. ed. São Paulo: Saraiva, 2001. p. 191.
} 


\subsubsection{Aspectos Gerais}

A Constituição Federal de 1988, com toda sua carga ideológica de solidariedade e igualdade, oxigenou as relações privadas, principalmente no aspecto contratual, as quais, como já assinalado anteriormente, passaram a receber maior intervenção estatal em busca de equilíbrio nas relações e principalmente da tutela da dignidade da pessoa humana.

É sabido que o Código Civil é uma lei geral, destinada aos iguais (relação paritária), enquanto o Código de Defesa do Consumidor é uma lei especial, destinada aos diferentes (os consumidores considerados mais fracos em relação aos fornecedores).

Quando o Código Civil de 2002 (cujo projeto, como é sabido, tramitou durante décadas no Congresso $\mathrm{Nacional}^{527}$ ) entrou em vigor, trouxe também inúmeros questionamentos quanto à sua compatibilidade com o Código de Defesa do Consumidor, como, por exemplo, em matéria pertinente aos vícios redibitórios, prazos prescricionais e responsabilidade civil.

Sob o aspecto subjetivo, Cláudia Lima Marques entende que não há colisão entre o Código de Defesa do Consumidor e o Código Civil, pois aquele regula a relação entre consumidor e fornecedor (especial), enquanto este regula toda relação privada não sujeita à lei especial (geral). ${ }^{528}$

Tem-se entendido que, havendo conflito entre os dois diplomas legislativos, deverá prevalecer o Código de Defesa do Consumidor em razão da aplicação do critério da especialidade $^{529}$. Giovanni Ettore Nanni entende que a solução do conflito deve ser feita tendo em vista a noção de relação de consumo como "situação jurídica", a qual deve ser

[...] funcionalizada e amoldada ao caso concreto, objetivando salvaguardar as diretrizes fundamentais da lei consumerista, assim também os valores emanados do Código Civil e os princípios constitucionais axiológicos de proteção à dignidade da pessoa humana (art. $1^{\circ}$, III, da CF), da solidariedade

\footnotetext{
${ }^{527}$ O que leva José de Oliveira Ascensão a afirmar que "a ordem cronológica dos diplomas está invertida. O Código mais velho é o CC-2002, o novo é o CDC-90”. (ASCENSÃO, José de Oliveira. As pautas de valoração do conteúdo dos contratos no Código de Defesa do Consumidor e no Código Civil. In: LOTUFO, Renan; RODRIGUES MARTINS, Fernando (Coord.). 20 anos do Código de Defesa do Consumidor - conquistas, desafios e perspectivas. São Paulo: Saraiva, 2011, p. 217).

${ }^{528}$ MARQUES, Cláudia Lima. O “diálogo das fontes" como método da nova Teoria Geral do Direito. In: (coord.). Diálogo das fontes. Do conflito à coordenação de normas do direito brasileiro. São Paulo: Revista dos Tribunais. 2012, p. 33.

529 "Tendo em vista o caráter de lei geral do CC e de lei especial do CDC, as disposições daquele que são convergentes ou complementares com as deste em nada prejudicarão ao consumidor, podendo ser eventualmente aplicadas supletivamente em seu benefício. As disposições divergentes não serão aplicáveis ao consumidor, também em razão da especialidade" (PASQUALOTTO, Adalberto. O Código de Defesa do Consumidor em face do Código Civil de 2002. São Paulo: Revista dos Tribunais, 2002. p. 151).
} 
(art. $3^{\circ}$, I, da CF) e da livre iniciativa (arts. $1^{\circ}$, IV, e 170, caput, da CF). ${ }^{530}$

Sob este aspecto, a relação de consumo é uma situação jurídica que deve cumprir as funções que dela se esperam, "sem obstaculizar a promoção do direito e a obtenção dos fins colimados pela própria lei e a sociedade ${ }^{531}$, entre os quais os princípios consagrados no artigo $4^{\circ}$ do Código de Defesa do Consumidor, no Código Civil e na Constituição Federal", 532

Para alguns autores, como Cláudia Lima Marques ${ }^{533} 534$, os critérios clássicos de solução de conflitos de normas, quais sejam cronológico, hierárquico e especialidade, não atendem à realidade do "pluralismo pós-moderno", 535 ou seja, à multiplicidade de fontes e disposições normativas. Para a autora, a nova visão para os referidos critérios devem "dialogar"

[...] a nova hierarquia, que é a coerência dada pelos valores constitucionais e a prevalência dos direitos humanos; a nova especialidade, que é a ideia de complementação ou aplicação subsidiária das normas especiais, entre elas, com tempo e ordem nesta aplicação, primeiro a mais valorativa, depois, no que couberem, as outras; e a nova anterioridade, que não vem do tempo de promulgação da lei, mas sim da necessidade de adaptar o sistema cada vez que uma lei nele é inserida pelo legislador. Influências recíprocas guiadas pelos valores constitucionais vão guiar este diálogo de adaptação sistemático.

Para a doutrina especializada, considerando-se a unidade do ordenamento jurídico, o Direito, por ter várias fontes legislativas, deveria buscar a harmonia e a coordenação entre as normas. É a chamada "coerência derivada ou restaurada", que procura "uma eficiência não só hierárquica, mas funcional do sistema plural e complexo de nosso direito contemporâneo, a

\footnotetext{
${ }^{530}$ NANNI, Giovanni Ettore. Relação de consumo: uma situação jurídica em interação entre o Código de Defesa do Consumidor e o Código Civil. In. LOTUFO, Renan; RODRIGUES MARTINS, Fernando (Coord.). 20 anos do Código de Defesa do Consumidor - conquistas, desafios e perspectivas. São Paulo: Saraiva, 2011, p. 141.

${ }^{531}$ Como por exemplo, a proteção à livre iniciativa, a propriedade privada e a livre concorrência (NANNI, Giovanni Ettore. Relação de consumo: uma situação jurídica em interação entre o Código de Defesa do Consumidor e o Código Civil. In: LOTUFO, Renan; RODRIGUES MARTINS, Fernando (Coord.). 20 anos do Código de Defesa do Consumidor - conquistas, desafios e perspectivas. São Paulo: Saraiva, 2011, p. 142).

${ }_{533}^{532}$ Loc. cit.

${ }^{533}$ MARQUES, Cláudia Lima. O "diálogo das fontes" como método da nova Teoria Geral do Direito. In: (Coord.). Diálogo das fontes. Do conflito à coordenação de normas do direito brasileiro. São Paulo: Revista dos Tribunais. 2012, p. 21.

${ }^{534}$ Cláudia Lima Marques apoia-se no posicionamento de Erik Jayme que já alertava em 1995, em seu Curso Geral de Haia que os tempos pós-modernos não mais permitem as soluções advindas dos critérios citados, pois sequer a hierarquia entre estes critérios é clara, "mas apenas dos valores constitucionais". (MARQUES, Cláudia Lima. Op. cit., p. 27).

${ }^{535}$ Para Erik Jayme, diante do "atual "pluralismo pós-moderno" de um direito com fontes legislativas plúrimas, ressurge a necessidade de coordenação entre as leis no mesmo ordenamento, como exigência para um sistema jurídico eficiente e justo" (MARQUES, Cláudia Lima. et al.. Comentários ao Código de Defesa do Consumidor. São Paulo: Revista dos Tribunais, 2003. p. 24).
} 
evitar a "antinomia", a incompatibilidade" ou a "não coerência"”, 536

Cumprindo este objetivo, Erik Jayme ${ }^{537}$ cunhou a expressão "diálogo das fontes" (Dialog der Quellen) para uma teoria que, segundo Cláudia Lima Marques, se insere "na grande tradição da visão sistemática e funcional da ordem jurídica, atualizada por uma visão internacional e cultural do direito e uma nova perspectiva mais humanista ${ }^{538}$ sobre a relação entre as normas". 539

O "diálogo das fontes" propõe a "aplicação simultânea, coerente e coordenada das plúrimas fontes legislativas convergentes". ${ }^{540} \mathrm{O}$ uso da palavra "diálogo" serve justamente para expressar que há uma reciprocidade de influências, porque há aplicação conjunta das duas normas, ao mesmo tempo e ao mesmo caso, seja complementarmente, seja subsidiariamente, seja permitindo a opção voluntária das partes sobre a fonte prevalente, ou ainda pela opção por uma solução flexível e aberta, de interpenetração, ou a solução mais favorável ao mais fraco da relação. ${ }^{541}$

Segundo Cláudia Lima Marques, forte no pensamento de Erik Jayme, os direitos humanos, os direitos fundamentais e constitucionais, os tratados, leis e códigos não se excluem, não se revogam mutuamente, mas "falam" uns aos outros, cabendo ao juiz a função de coordenar estas fontes. ${ }^{542}$ As fontes dialogam, "em uma aplicação conjunta e harmoniosa guiada pelos valores constitucionais, e, hoje, em especial, pela luz dos direitos humanos". 543

O posicionamento de Jayme implicaria, segundo Marques, em uma mudança de paradigma: da revogação de uma das normas em conflito do sistema jurídico (ou "monólogo" de uma só norma em conflito para convivência dessas normas, "ao diálogo das normas para alcançar a sua ratio, e a finalidade "narrada' ou "comunicada" em ambas, sob a luz da Constituição, de seu sistema de valores e dos direitos humanos em geral". 544

\footnotetext{
${ }_{536}^{537}$ MARQUES, Cláudia Lima. Contratos no Código de Defesa do Consumidor. São Paulo: RT, 2002. p. 693.

${ }^{537}$ O Superior Tribunal de Justiça vem adotando a teoria proposta por Jayme em diversos julgados, como AgRg no REsp 1196537/MG; REsp 1184765/PA.

${ }^{538}$ A teoria seria humanista e também humanizadora, "pois utiliza o sistema de valores, para tem em conta em sua coordenação ou a restaurar a coerência abalada pelo conflito de leis, o ponto de vista concreto e material das fontes em "colisão" (MARQUES, Cláudia Lima. O "diálogo das fontes" como método da nova Teoria Geral do Direito. In: (Coord.). Diálogo das fontes. Do conflito à coordenação de normas do direito brasileiro. São Paulo: Revista dos Tribunais. 2012, p. 25).

${ }^{539}$ MARQUES, Cláudia Lima. Op. cit., p. 23.

${ }^{540}$ MARQUES, Cláudia Lima. et. al. Comentários ao Código de Defesa do Consumidor. São Paulo: Revista dos Tribunais, 2003. p. 24.

${ }^{541}$ MARQUES, Cláudia Lima. O "diálogo das fontes" como método da nova Teoria Geral do Direito. In: MARQUES, Cláudia Lima (Coord.). Diálogo das fontes. Do conflito à coordenação de normas do direito brasileiro. São Paulo: Revista dos Tribunais. 2012, p. 28.

${ }^{542}$ Ibid., p. 18-19.

${ }^{543}$ Ibid., p. 27.

${ }^{544}$ Ibid., p. 29.
} 
Seguindo os ensinamentos de Erik Jayme, a doutrina ${ }^{545}$ discorre sobre a existência de três diálogos possíveis entre o Código de Defesa do Consumidor e o Código Civil.

Primeiramente, fala-se em um diálogo sistemático de coerência, em que uma lei poderia servir de base conceitual para a outra, "especialmente se uma lei é geral e a outra especial, se uma lei é central do sistema e a outra um microssistema específico, não completo materialmente, apenas com completude subjetiva de tutela de um grupo da sociedade". 546 Neste sentido, segundo Cláudia Lima Marques, os conceitos de nulidade, pessoa jurídica, prova, decadência, prescrição, entre outros, não estão definidos no Código de Defesa do Consumidor; entretanto, são conceituados no Código Civil e terão aplicação nas relações consumeristas. ${ }^{547}$ Neste diálogo, ambas as leis preservam o seu âmbito de aplicação. ${ }^{548}$

Uma segunda espécie de diálogo é denominado diálogo sistemático de complementaridade e subsidiariedade, para representar as hipóteses em que "na aplicação coordenada das duas leis, uma lei pode complementar a aplicação da outra, a depender de seu campo de aplicação no caso concreto" ${ }^{, 49}$, como Cláudia Lima Marques exemplifica:

[...] as cláusulas gerais de uma lei podem encontrar uso subsidiário ou complementar em caso regulado pela outra lei. Subsidiariamente, o sistema geral de responsabilidade civil sem culpa ou o sistema geral de decadência podem ser usados para regular aspectos de casos de consumo, se trouxer normas mais favoráveis ao consumidor. ${ }^{550} 551$

Deste diálogo, Miragem afirma que, primeiramente, resulta a conclusão de que não houve a revogação do Código de Defesa do Consumidor pelo Código Civil, em razão de que este não dispõe sobre relação de consumo. Além disso, possibilita a aplicação das disposições do Código Civil às relações de consumo, hipótese que, inclusive, é admitia pelo artigo $7^{\circ}$,

\footnotetext{
${ }^{545}$ MARQUES, Cláudia Lima. et al. Comentários ao Código de Defesa do Consumidor. São Paulo: Revista dos Tribunais, 2003. p. 28.

${ }^{546}$ Id. Contratos no Código de Defesa do Consumidor. São Paulo: RT, 2002. p. 719.

${ }^{547}$ Loc. cit.

548 MIRAGEM, Bruno. Eppur si muove: diálogo das fontes como método de interpretação sistemática. In: MARQUES, Cláudia Lima (Coord.). Diálogo das fontes. Do conflito à coordenação de normas do direito brasileiro. São Paulo: Revista dos Tribunais. 2012, p. 75.

${ }^{549}$ MARQUES, Cláudia Lima. Contratos no Código de Defesa do Consumidor. Op. cit., p. 719

${ }^{550}$ Ibid., p. 720.

${ }^{551}$ No mesmo sentido, posiciona-se Giovanni Ettore Nanni: "os dispositivos do Código Civil somente podem disciplinar as relações de consumo se forem mais favoráveis ao consumidor" (NANNI, Giovanni Ettore. Relação de consumo: uma situação jurídica em interação entre o Código de Defesa do Consumidor e o Código Civil. In: LOTUFO, Renan; RODRIGUES MARTINS, Fernando (Coord). 20 anos do Código de Defesa do Consumidor - conquistas, desafios e perspectivas. São Paulo: Saraiva, 2011, p. 123).
} 
caput, do Código de Defesa do Consumidor. ${ }^{552}$

Por fim, há o chamado diálogo das influências recíprocas sistemáticas

[...] como no caso de uma possível redefinição do campo de aplicação de uma lei (assim, por exemplo, as definições de consumidor stricto sensu e de consumidor equiparado podem sofrer influências finalísticas do novo Código Civil, uma vez que esta lei nova vem justamente para regular as relações entre iguais, dois iguais-consumidores ou dois iguais-fornecedores entre si no caso de dois fornecedores, trata-se de relações empresariais típicas, em que o destinatário final fático da coisa ou do fazer comercial é um outro empresário ou comerciante), ou como no caso da possível transposição das conquistas do Richterrecht (direito dos juízes) alcançadas em uma lei para a outra. É a influência do sistema especial no geral e do geral no especial, um diálogo de double sens (diálogo de coordenação e adaptação sistemática). ${ }^{553}$

Para Cláudia Lima Marques, o di-a-logos (entre CDC e CC) já tem uma lógica/racionalidade preponderante: a promoção pelo julgador dos direitos do consumidor, conforme impõe o artigo $5^{\circ}$, inciso XXXII, da Constituição Federal, ““"na forma da lei”, mais favorável a este sujeito de direitos vulnerável, promover a manutenção e a efetivação de seus direitos e pretensões, nunca aplicar as duas leis na "forma menos favorável" ao consumidor!". 554 O Leitmotiv da teoria da Jayme, ou seja, o motivo-guia, seria os direitos humanos e, "nesse sentido, só pode beneficiar os consumidores e não prejudicá-los". 555,556

Segundo a autora,

A lógica de preponderância da "lei" menos favorável ao consumidor não é di-a-logos, é aplicação apenas da lei menos favorável: é mono-logo (monólogo) da lei especial in pejus. Diálogo das fontes é sempre a aplicação harmônica e sistemática das leis especiais e gerais a favor dos direitos fundamentais e dos valores mais elevados sociais e públicos. ${ }^{557}$

Nas palavras de Gustavo Tepedino,

\footnotetext{
552 MIRAGEM, Bruno. Eppur si muove: diálogo das fontes como método de interpretação sistemática. In: MARQUES, Cláudia Lima (Coord.). Diálogo das fontes. Do conflito à coordenação de normas do direito brasileiro. São Paulo: Revista dos Tribunais. 2012, p. 76.

${ }^{553}$ MARQUES, Cláudia Lima. Contratos no Código de Defesa do Consumidor. São Paulo: RT, 2002. p. 720.

${ }^{554}$ Id. Cláudia Lima. O "diálogo das fontes" como método da nova Teoria Geral do Direito. In: (Coord.).

Diálogo das fontes. Do conflito à coordenação de normas do direito brasileiro. São Paulo: Revista dos Tribunais. 2012., p. 61.

${ }^{555}$ Ibid., p. 62.

${ }^{556}$ Em hipótese semelhante, o Superior Tribunal de Justiça já decidiu que "consoante a Teoria do Diálogo das Fontes, as normas gerais mais benéficas supervenientes preferem à norma especial concebida para conferir tratamento privilegiado a determinada categoria, a fim de preservar a coerência do sistema normativo" (AgRg no REsp 1196537/MG, Rel. Ministro Luiz Fux, Primeira Turma, julgado em 03/02/2011, DJe 22/02/2011).

${ }^{557}$ MARQUES, Cláudia Lima. Contratos no Código de Defesa do Consumidor. Op. cit., p. 729.
} 
Não se devem tomar o Código Civil e o Código de Defesa do Consumidor por diplomas contrastantes, senão complementares, no âmbito da complexidade do ordenamento. Constituem-se, cada um em sua esfera de atuação, verdadeiros instrumentos para promoção da pessoa humana. ${ }^{558}$

Partindo-se da noção de aplicação de fontes normativas plúrimas, mas harmônicas e coordenadas, é que o equilíbrio contratual por onerosidade excessiva será analisado no Código Civil e no Código de Defesa do Consumidor, avaliando-se a possibilidade de um diálogo entre estes dois sistemas, mormente tendo-se em consideração que o Direito do Consumidor é um ramo relativamente recente do Direito, visto que surgiu na década de 60 do século passado.

No capítulo anterior, foram analisados os requisitos necessários para a configuração do desequilíbrio superveniente hábil a ensejar a revisão/resolução do contrato paritário (existência de um contrato de execução continuada, sucessiva ou diferida; excessiva onerosidade na prestação para uma das partes; acontecimentos extraordinários e imprevisíveis e extrema vantagem para a outra parte). Essas exigências são acrescidas da necessidade de inexistência de estado moroso do devedor por ocasião do fato superveniente, bem como da necessidade de que o desequilíbrio não seja inerente à álea normal do contrato.

Passa-se, então, a analisar tais exigências sob a ótica do Direito do Consumidor.

\subsubsection{Inexigência de imprevisibilidade e extraordinariedade do evento superveniente}

Uma diferença substancial entre o regime adotado pelo Código Civil e o regime adotado pelo Código de Defesa do Consumidor quanto ao equilíbrio contratual por alteração das circunstâncias está relacionada aos requisitos da imprevisibilidade e da extraordinariedade do evento que tornou a obrigação excessivamente onerosa, pois os mesmos não são exigidos pelo Código de Defesa do Consumidor ${ }^{559}$, mas o são pelo Código Civil, não sem críticas por parte da doutrina, conforme já analisado. Portanto, conforme aponta Rogério Ferraz Donnini, para a relação consumerista basta

[...] que haja quebra do equilíbrio contratual, a ausência de equivalência nas prestações, gerando, dessa forma, onerosidade excessiva para o consumidor. Em

\footnotetext{
558 TEPEDINO, Gustavo. A aplicabilidade do Código Civil nas relações de consumo: diálogos entre o Código Civil e o Código de Defesa do Consumidor. In: LOTUFO, Renan; MARTINS, Fernando Rodrigues (Coord.) 20 anos do Código de Defesa do Consumidor: conquistas, desafios e perspectivas. São Paulo: Saraiva, 2011, p. 72.

${ }^{559}$ Neste sentido: Apelação com revisão n. 1023997009 do Tribunal de Justiça do Estado de São Paulo, $28^{\mathrm{a}}$ Câmara de Direito Privado, Relatora Silvia Rocha, Julgamento em 03.02.2009.
} 
sendo assim, para que este possa pleitear, em juízo, a revisão de cláusula que provoque esse desequilíbrio do contrato não se faz necessária a comprovação de que o fato seja imprevisível, imprevisto, extraordinário ou mesmo irresistível, mas apenas um acontecimento superveniente, que poderia ter sido previsto e não foi, e que cause onerosidade excessiva para o consumidor. ${ }^{560}$

Rizzato Nunes também se manifesta neste sentido, afirmando:

Para que se faça a revisão do contrato, basta que após ter ele sido firmado surjam fatos que o tornem excessivamente oneroso. Não se pergunta, nem interessa saber, se, nada data de seu fechamento, as partes podiam ou não prever os acontecimentos futuros. Basta ter havido alteração substancial capaz de tornar o contrato excessivo para o consumidor. ${ }^{561}$

A justificativa para a diferença entre os dois diplomas legais está no fato de que o Código de Defesa do Consumidor é "funcionalizado à proteção da pessoa em situação de particular vulnerabilidade". 562

Neste diapasão, segundo alguns autores, o Código de Defesa do Consumidor teria adotado a teoria da base do negócio jurídico de Karl Larenz ${ }^{563}$, do que discorda Wladimir Alcibíades Marinho Falcão Cunha, ao afirmar que a teoria de Larenz também exige, para a quebra da base do negócio, que os acontecimentos sejam imprevisíveis. ${ }^{564}$

Os Tribunais Estaduais já se posicionaram no sentido de não exigir o requisito da imprevisibilidade. $^{565}$

${ }^{560}$ DONNINI, Rogério Ferraz. A revisão dos contratos no Código Civil e no Código de Defesa do Consumidor. 2. ed. São Paulo: Saraiva, 2001. p. 193.

${ }^{561}$ NUNES, Rizatto. Comentários ao Código de Defesa do Consumidor. 7. ed. São Paulo: Saraiva, 2012. p. 127.

562 TEPEDINO, Gustavo. A aplicabilidade do Código Civil nas relações de consumo: diálogos entre o Código Civil e o Código de Defesa do Consumidor. In: LOTUFO, Renan; MARTINS, Fernando Rodrigues (Org). 20 anos do Código de Defesa do Consumidor: conquistas, desafios e perspectivas. conquistas, desafios e perspectivas. São Paulo: Saraiva, 2011, p. 80.

${ }^{563}$ SANTOS, Antonio Jeová. Função Social: Lesão e Onerosidade Excessiva nos Contratos. São Paulo: Método, 2002 p. 294; MIRAGEM, Bruno. Direito do Consumidor. São Paulo: Revista dos Tribunais, 2008. p. 128; GARCIA, Leonardo de Medeiros. Direito do consumidor: código comentado e jurisprudência. 8. ed. Niterói: Impetus, 2012. p. 70.

564 CUNHA, Wladimir Alcibíades Marinho Falcão. Revisão Judicial dos Contratos: do Código de Defesa do Consumidor ao Código Civil de 2002. São Paulo: Método, 2007. p. 226.

${ }^{565}$ APELAÇÃO - REVISIONAL - JUROS - CAPITALIZAÇÃO. - Pacífica a natureza consumerista do contrato com a instituição financeira, nos termos dos artigos 2o e 3o do Código de Defesa do Consumidor- Súmula 297 do Superior Tribunal de Justiça; - Pedido revisional, em razão da onerosidade excessiva - aplicação do CDC $\left(\right.$ art. $\left.6^{\circ}, \mathrm{V}\right)$, que afasta a necessidade de fato extraordinário, basta a constatação do desequilíbrio contratual; Somente haverá possibilidade de capitalização de juros com relação aos contratos firmados posteriormente à edição da Medida Provisória 1.963-17/2000, de 31 de março de 2000 (atualmente reeditada sob o ${ }^{\circ} 2.170$ 36/2001), desde que haja previsão contratual expressa nesse sentido; - Ressalvado o entendimento pessoal, aplica-se a Súmula Vinculante n. 7, inclusive para contratos anteriores à sua edição, em nome da uniformização da jurisprudência. Em caso de os juros remuneratórios não encontrarem prévia estipulação contratual devem ser aplicadas as taxas de mercado para as operações equivalentes; - Para aplicação do art. 42, parágrafo único do Código de Defesa do Consumidor não é preciso que se comprove a má-fé do fornecedor que cobrou e recebeu a quantia de forma indevida, bastando sua responsabilidade pelo evento danosp. A única 
Segundo Bruno Miragem, ao afastar a exigência da imprevisibilidade, o CDC impede a transferência de riscos do negócio ao consumidor e promove "uma maior objetivação do exame e avaliação do comportamento das partes do contrato de consumo, afasta a exigência (e com isso a necessidade de comprovação) de que o fato que tenha dado causa à desproporção fosse imprevisível". 566

O Código de Defesa do Consumidor não exige também o requisito da

escusa aceitável seria o engano justificável, que não se mostrou presente no caso em estudo. Precedentes do STJ. Restituição em dobro devida. RECURSO PROVIDO EM PARTE, para afastar os juros capitalizados, limitá-los à taxa média de mercado e restituir em dobro os valores pagos indevidamente.

(Apelação n. 9052817-73.2009.8.26.0000. Relatora Maria Lúcia Pizzotti. Comarca de Mirassol. 20ª̂amara de Direito Privado do Tribunal de Justiá do Estado de São Paulo. Julgamento em 23.11.2012).

Arrendamento mercantil - Ação de Revisão contratual cumulada com repetição de indébito - Improcedência Aumento repentino e substancial do dólar - Situação de onerosidade excessiva para o arrendatário Aplicabilidade do Código de Defesa do Consumidor, que dispensa a imprevisibilidade do fato superveniente Acolhimento do pedido, na esteira da atual jurisprudência do Superior Tribunal de Justiça, repartindo-se pela metade, entre os contratantes, o índice de reajuste segundo o dólar americano, a partir de 13 de janeiro de 1999, com observância dos limites do pedido (CPC, art. 460) - Inversão do ônus da sucumbência - Recurso provido (Apelação n. 9215526-89.2008.8.26.0000. Relator Cesar Lacerda. Comerca de Barueri. 28 Câmara de Direito Privado. Julgamento em 01.06.2010).

APELAÇÃO CÍVEL. AÇÃO REVISIONAL. ARRENDAMENTO MERCANTIL. APLICABILIDADE DO CDC. CORREÇÃO DA PRESTAÇÃO VINCULADA AO DÓLAR NORTE-AMERICANO. LIBERAÇÃO CAMBIAL. ONEROSIDADE EXCESSIVA. TEORIA DA QUEBRA DA BASE NEGOCIAL (ART. 6 ${ }^{\circ}$, INCISO V, DO CDC). AUSÊNCIA DE PROVA DE QUE OS RECURSOS UTILIZADOS NA OPERAÇÃO FINANCEIRA DE LEASING FORAM CAPTADOS NO EXTERIOR. ANTECIPAÇÃO DO VALOR RESIDUAL GARANTIDO E EXIGÊNCIA DO SEU PAGAMENTO AINDA QUE A PRETENSÃO SEJA A DEVOLUÇÃO DO BEM. DESCARACTERIZAÇÃO DO LEASING. SÚMULA No 263 DO STJ. São direitos básicos do consumidor a modificação de cláusulas contratuais que estabeleçam prestações desproporcionais ou sua revisão em razão de fatos supervenientes que as tornem excessivamente onerosas, nos termos do inciso $\mathrm{V}$, do art. $6^{\circ}$ do diploma consumerista, plenamente aplicável ao caso dos autos, vislumbrando-se patente na legislação pátria a consagração da cláusula rebus sic stantibus, bem como o acolhimento da Teoria da Quebra da Base Negocial, que dispensa o requisito da imprevisibilidade do acontecimento superveniente para se possibilitar a revisão da avença. Partilho do entendimento de que, em se tratando de oneração excessiva causada ao consumidor pela ocorrência de liberação cambial, naqueles contratos onde eleito o dólar norteamericano como indexador, somente não é possível a revisão de tal cláusula contratual se a empresa arrendadora provar ter captado no exterior os valores utilizados na operação financeira em causa, pois de outro modo estar-se-ia impingindo prejuízo à arrendadora, desequilibrando, também, a relação negocial. Na casuística apresentada, a demandada não logrou comprovar a origem do capital utilizado na operação de leasing em discussão, o que lhe incumbia, motivo pelo qual afasto o indexador contratado, pois provoca a onerosidade exacerbada das prestações que incumbe ao consumidor adimplir. Na espécie, em face da exigência do pagamento do VRG, ainda que a pretensão seja a de devolução do bem ao término do contrato, resta desnaturado o leasing, tratando-se, portanto, de contrato de compra e venda. Ademais, o egrégio Superior Tribunal de Justiça veio a editar a Súmula 263 pondo fim às divergências jurisprudenciais que ainda persistiam sobre o assunto. JUROS REMUNERATÓRIOS- adoto o entendimento majoritário para limitar os juros ao percentual de, no máximo, $12 \%$ ao ano. Demais, ainda que admissível, em tese, a cobrança de juros acima do patamar de $12 \%$ ao ano, a prévia autorização do CMN - essencial para tal desiderato não foi comprovada pela empresa arrendadora. CAPITALIZAÇÃ̃O DOS JUROS - inadmissível capitalização em qualquer periodicidade, por ausência de previsão legal. CORREÇÃO MONETÁRIA - devido a revisão do contrato deve ser aplicado de atualização monetária e o IGP-M é o índice que mais se aproxima da efetiva variação dos percentuais inflacionários. MULTA CONTRATUAL - o contrato prevê a incidência de multa no percentual legal. COMISSÃO DE PERMANÊNCIA - inviabilidade de cobrança por ofensa ao CDC e ao disposto no art. 115, do Código Civil de 1916. REPETIÇÃO DE INDÉBITO - viável, na forma simples, por aplicação do CDC. Admissível a compensação. APELAÇÃO DA AUTORA PROVIDA EM PARTE E APELAÇÃ O DA RÉ DESPROVIDA. (Apelação Cível No 70004579736, Segunda Câmara Especial Cível, Tribunal de Justiça do RS, Relator: Marilene Bonzanini Bernardi, Julgado em 15/05/2003).

${ }^{566}$ MIRAGEM, Bruno. Direito do Consumidor. São Paulo: Revista dos Tribunais, 2008. p. 128. 
extraordinariedade do evento, ou seja, para a revisão contratual, basta a quebra do equilíbrio contratual,

[...] a ausência de equivalência nas prestações, gerando, dessa forma, onerosidade excessiva para o consumidor. Em sendo assim, para que este possa pleitear, em juízo, a revisão da cláusula que provoque esse desequilíbrio do contrato não se faz necessária a comprovação de que o fato seja imprevisível, imprevisto, extraordinário ou mesmo irresistível, mas apenas um acontecimento superveniente, que poderia ter si previsto e não foi, e que cause onerosidade excessiva para o consumidor. ${ }^{567}$

Certamente, a legislação consumerista atende melhor aos interesses do consumidor, tornando desnecessário qualquer argumento ou prova da imprevisibilidade do evento que torne a obrigação excessivamente onerosa. O Código Civil já vem sendo bastante criticado pela exigência da imprevisibilidade e extraordinariedade do evento, tanto que já há proposta de modificação legislativa para excluir tais requisitos, conforme analisado no item 5.1.3 do capítulo anterior. Portanto, a exigência da imprevisibilidade e da extraordinariedade do evento superveniente pelo Código Civil "impossibilita a influência ("diálogo") deste diploma legal no microssistema do Código de Defesa do Consumidor, que possui norma mais flexível aos consumidores". 568

\subsubsection{Possibilidade de revisão do contrato de consumo ex officio}

Diferentemente da relação privatística, em que a intervenção judicial se opera mediante provocação da parte, a proteção ao consumidor é considerada matéria de ordem pública, até mesmo pelo fato de que o consumidor é essencial para a atividade econômica. Em razão disto, o juiz, in concreto, constatando a alteração das circunstâncias, poderá emitir "sentença determinativa, de conteúdo constitutivo-integrativo e mandamental, vale dizer, exercendo verdadeira atividade criadora, complementando ou mudando alguns elementos da relação jurídica de consumo já constituída". 569

Havendo desequilíbrio contratual, a postura do magistrado é muito mais ativa que na relação privatística, na qual o magistrado somente poderá atuar mediante provocação da parte

\footnotetext{
${ }^{567}$ DONNINI, Rogério Ferraz. A revisão dos contratos no Código Civil e no Código de Defesa do Consumidor. 2. ed. São Paulo: Saraiva, 2001. p. 193.

568 COSTA DE AZEVEDO, Fernando. Os desequilíbrios gerados por vantagem e onerosidade excessivas no Direito do Consumidor e a possibilidade de aplicação do Diálogo das fontes entre Código de Defesa do Consumidor e Código Civil 2002. In: MARQUES, Cláudia Lima (Coord.). Diálogo das fontes. Do conflito à coordenação de normas do direito brasileiro. São Paulo: Revista dos Tribunais. 2012, p. 341.

${ }^{569}$ NERY JÚNIOR. Nelson. Código de Defesa do Consumidor Comentado pelos Autores do Anteprojeto. 7. ed. Rio de Janeiro: Forense Universitária, 2001.
} 
prejudicada, conforme já assinalado acima no Capítulo V. Além disso, o limite da reconstrução do equilíbrio contratual está na oferta de modificação equitativa por parte do réu na demanda revisionista privatística. Esse dispositivo referente à proposta de modificação equitativa por parte do réu na revisão, como já analisado, recebe críticas da doutrina civilista e felizmente não foi abraçado pela legislação consumerista. Exigir-se a proposta de modificação equitativa por parte do réu praticamente tornaria inviável o direito básico do consumidor à revisão contratual conforme contemplado no artigo $6^{\circ}$, inciso $\mathrm{V}$ do Código de Defesa do Consumidor.

Nesse sentido, ao julgar recurso de apelação, o Tribunal de Justiça do Estado de São Paulo reviu um contrato de compromisso de compra e venda em que os réu-reconvientes não especificaram em que consistia a "abusividade" atribuída à relação contratual entre as partes, "justificando-se intervenção judicial ex officio no negócio entabulado". ${ }^{570}$ Evidente que a intervenção judicial ex officio somente se operará no caso concreto. Já na relação paritária, a parte prejudicada deverá deduzir os fatos constitutivos do seu direito à revisão, apontado o fato superveniente que alterou as circunstâncias.

Não é de se olvidar, entretanto, a existência da Súmula 381 do Superior Tribunal de Justiça, a qual dispõe que "Nos contratos bancários, é vedado ao julgador conhecer, de ofício, da abusivade das cláusulas", ressaltando-se que há grande discussão quanto à sua constitucionalidade. De acordo com a doutrina ${ }^{571}$, a referida Súmula não privilegia a melhor interpretação do artigo $1^{\circ}$ do CDC e do artigo $5^{\circ}$, XXXII da Constituição Federal, em especial após a decisão proferida pelo Supremo Tribunal Federanl na ADIn 2.591, que entendeu que as relações de consumo de natureza bancária ou financeira são regidas pelo Código de Defesa do Consumidor.

\subsubsection{Excessiva onerosidade para uma das partes}

Conforme abordado no item 5.1.2 do capítulo anterior, ao tratar da alteração das circunstâncias, o Código Civil, em seu artigo 478, exige que a prestação de uma das partes se torne "excessivamente onerosa", ao passo que o Código de Defesa do Consumidor, no já citado artigo $6^{\circ}$, inciso $\mathrm{V}$, menciona o direito básico do consumidor à "modificação das cláusulas contratuais que estabeleçam prestações desproporcionais ou sua revisão em razão de

\footnotetext{
570 Apelação Cível n. 9119303-45.2006.8.26.0000, 9a Câmara de Direito Privado, Relator Piva Rodrigues, Comarca de São Paulo, Julgamento em 19.04.2011.

571 MARQUES, Cláudia Lima. Contratos no Código de Defesa do Consumidor. São Paulo: Revista dos Tribunais, 2002. p. 959.
} 
fatos supervenientes que as tornem excessivamente onerosas”.

O Código Civil, como visto, não esclareceu o que seria uma prestação excessivamente onerosa, cabendo à doutrina trazer elementos para a aferição do equilíbrio contratual, tais como: reciprocidade de obrigações e de direitos; comutatividade; equivalência, proporcionalidade; proibição de enriquecimento sem causa, função social do contrato e distribuição de ônus e riscos.

Considerando que a alteração das circunstâncias vem sendo objeto de estudos há muito mais tempo no Direito Civil, culminando com os vários critérios de busca da melhor solução para a retomada do equilíbrio contratual, nada impede que sejam aplicados à relação consumerista desde que impliquem na proteção do consumidor e defesa de seus melhores interesses, ressalvando-se também a questão relativa à alocação dos riscos contratuais os quais na relação de consumo cabem ao fornecedor. Trata-se de um verdadeiro diálogo de influência sistemática, considerando-se as conquistas doutrinárias alcançadas no secular Direito Civil.

O Código de Defesa do Consumidor, por seu turno, traz elementos inexistentes na legislação Civil para a aferição de uma vantagem exagerada, a qual acaba por revelar a ocorrência de um desequilíbrio contratual. Tais elementos estão contidos no parágrafo $1^{\circ}$ do artigo 51, o qual traz, de forma exemplificativa, presunções de vantagem exagerada. O inciso I do referido parágrafo considera vantagem exagerada aquela que "ofende os princípios fundamentais do sistema jurídico a que pertence”. Já o inciso II considera vantagem exagerada aquela que "restringe direitos ou obrigações fundamentais inerentes à natureza do contrato, de tal modo a ameaçar o seu objeto ou o equilíbrio contratual”. Por fim, o inciso III prevê como vantagem exagerada aquela que "se mostra excessivamente onerosa para o consumidor, considerando-se a natureza e conteúdo do contrato, o interesse das partes e outras circunstâncias peculiares do caso".

Por outro lado, atentando-se para as diretrizes trazidas pelo Código de Defesa do Consumidor quanto à "vantagem exagerada", as quais, repete-se, inexistem no Código Civil, é possível afirma a existência de um diálogo sistemático de coerência e que os elementos trazidos pelo CDC para aferição de uma vantagem exagerada possam servir de base conceitual para o Código Civil, mais especificamente para a aplicação do disposto no 478, quando menciona a expressão "extrema vantagem para a outra parte", apesar de ser o CDC considerado uma lei especial. 
Conforme ensina Fernando Costa de Azevedo ${ }^{572}$, é de se esclarecer que a hipótese contemplada no citado inciso III - o qual utiliza a expressão "excessivamente onerosa" - não implica uma "situação de onerosidade excessiva" como uma "situação de desequilíbrio excessivo gerada pelo fato superveniente, não provocado pela conduta de um dos contratantes", mas como uma hipótese de desequilíbrio genético. Entretanto, segundo o autor, a expressão "extrema vantagem para a outra", prevista no artigo 478 do Código Civil, pode ter seu critério interpretado a partir do disposto no artigo 51, parágrafo $1^{\circ}$, do $\mathrm{CDC}$.

$\mathrm{O}$ mesmo autor ressalta, ainda, quanto às situações de vantagem e onerosidade excessiva, a possibilidade de influência da sistemática consumerista na sistemática civilista, por intermédio das

[...] possibilidades e limites da experiência jurisprudencial relativa à aplicação da boa-fé objetiva nas relações de consumo para as relações obrigacionais civis (diálogo de coordenação e adaptação sistemática pela transposição das conquistas do Richterrecht [Direito dos Juízes] alcançado de uma lei para a outra $)^{573}$.

Somente a título de elucidação, um diálogo de influência também vem sendo observado entre o Código de Defesa do Consumidor e o Processo Civil em matéria de distribuição do ônus da prova, em um posicionamento já adotado, por exemplo, por Miguel Kfouri Neto ${ }^{574}$. Sobre este tema, lecionam Luiz Guilherme Marinoni e Daniel Mitidiero que “O ônus da prova pode ser distribuído de forma dinâmica, a partir do caso concreto pelo juiz da causa, a fim de atender à paridade de armas entre os litigantes e às especificidades do direito material afirmado em juízo". 575

Essa forma de distribuição do ônus probatório, inclusive, encontra-se expressa no artigo 262 do Anteprojeto do novo Código de Processo Civil, o qual prevê que "Considerando as circunstâncias da causa, o juiz poderá, em decisão fundamentada e observando o contraditório, atribuir o ônus da prova à parte que se encontrar em melhores condições de produzi-la." Na sequência, o parágrafo único do referido artigo prevê que "A dinamização do

\footnotetext{
572 COSTA DE AZEVEDO, Fernando. Os desequilíbrios gerados por vantagem e onerosidade excessivas no Direito do Consumidor e a possibilidade de aplicação do Diálogo das fontes entre Código de Defesa do Consumidor e Código Civil 2002. In: MARQUES, Cláudia Lima (Coord.). Diálogo das fontes. Do conflito à coordenação de normas do direito brasileiro. São Paulo: Revista dos Tribunais. 2012, p. 343.

573 Loc. cit.

574 KFOURI NETO, Miguel. Responsabilidade Civil dos Hospitais. São Paulo: Revista dos Tribunais, 2010 , p. 80-83.

575 MARINONI, Luiz Guilherme; MITIDIERO, Daniel. Código de Processo Civil Comentado Artigo Por Artigo. 4. ed. São Paulo: Revista dos Tribunais, 2012. p. 336.
} 
ônus da prova está sempre seguida de oportunidade para que a parte onerada possa desempenhar adequadamente seu encargo".

Não há dúvida de que a nova sistemática processual civil é resultado da influência que o Código de Defesa do Consumidor exerceu sobre o Processo Civil, quando em seu artigo $6^{\mathrm{o}}$, inciso VIII, tratou da inversão do ônus da prova, a favor do consumidor, quando, a critério do juiz, for verossímil a alegação ou quando for ele hipossuficiente, segundo as regras ordinárias de experiência.

Tal exemplo revela, no campo prático, a atenção do nosso sistema jurídico para o diálogo das fontes na pós-modernidade, superando posturas antigas incompatíveis com a pluralidade legislativa, que não permite de forma simplista a revogação da uma norma pela outra, impossibilitando suas coexistências.

\subsubsection{Do estado moroso do consumidor e a inimputabilidade}

Embora o Código Civil não faça qualquer menção expressa a que a parte sujeita à obrigação excessivamente onerosa decorrente de evento superveniente à formação do contrato não possa encontrar-se em mora para invocá-la, a doutrina vem entendendo que isto seja necessário, conforme exposto no item 5.2.2. do capítulo anterior. Assim, somente poderia pleitear a revisão/resolução do contrato a parte que não se encontrasse em mora no momento do evento que tornou a prestação excessivamente onerosa, lembrando-se também que tal exigência poderá ser expressamente prevista diante da existência do já citado Projeto de Lei 276/07.

Não é de se olvidar, entretanto, o posicionamento doutrinário exposto no mesmo item 5.2.2, e que parece mais acertado, que admite a propositura da demanda resolutória ou revisionista quando a mora for decorrente da alteração das circunstâncias, exercendo-se a pretensão "logo a seguir" ao evento superveniente que altera o equilíbrio contratual, sendo que, pautando-se pela boa-fé objetiva, é que seria aferida a razoabilidade do tempo necessário para a propositura da demanda.

Na relação consumerista não há qualquer previsão quanto à necessária ausência de estado moroso do devedor consumidor para utilização da via resolutória ou revisional, de forma que se mostra razoável que, ainda que o consumidor se encontre em mora, havendo a comprovação que sua conduta foi pautada pela boa-fé e que tentou rever o contrato extrajudicialmente, mas sem sucesso, e desde que presentes os demais requisitos, o juiz deve 
autorizar a revisão. ${ }^{576}$

Essa opção parece ser a mais acertada ao se considerar que o Código de Defesa do Consumidor não exige que o consumidor não se encontre em dia com suas obrigações para pleitear a revisão contratual. Tal exigência não se coaduna com a sistemática consumerista que procura facilitar a defesa do consumidor e lhe proporciona uma interpretação mais favorável. Um diálogo de influência dos preceitos teóricos desenvolvidos para o Direito Civil quanto à mora decorrente de fato superveniente com propositura de demanda revisionista logo na sequência pode incidir sobre o Direito do Consumidor. Isso não quer dizer, entretanto, que o consumidor pode abusar de seu direito e pleitear a revisão do contrato a qualquer momento, sem qualquer justificativa razoável.

Nesse sentido, o Tribunal de Justiça do Estado da Bahia decidiu, em revisional de contrato envolvendo matéria consumerista, que a "mora continuada e sequer justificada não comporta chancela do Judiciário”, ou seja, a

[...] mora renitente e injustificada não encontra albergue na legislação consumerista - como em nenhuma outra - e é prática que merece firme repúdio, jamais cogitando da chancela judicial ou legal. $\mathrm{O}$ desequilíbrio contratual é observado e combatido quando dificulta ou impossibilita que a parte cumpra aquilo que lhe compete como obrigação. Inexistindo essa disposição, correta a interpretação da $a$ quo ao obstar a pretensão do requerente. ${ }^{577}$

Certo é, portanto, que se o estado moroso for posterior ao evento que alterou as circunstâncias do contrato, tornando-o excessivamente oneroso, também será possível ao consumidor socorrer-se dos remédios processuais em busca do equilíbrio da relação contratual. Assim, o Tribunal de Justiça do Rio Grande do Sul já decidiu, em ação de busca e apreensão, que "A mora debitoris decorre da cobrança justa e correta dos valores devidos, conforme pactuado. Se a cobrança é exagerada e não encontra arrimo no contrato ou na lei, por óbvio, obnubila a situação moratória". 578

Da mesma forma compreendida para a relação paritária, a onerosidade excessiva não pode derivar de ato a que a própria parte tenha dado causa. Entretanto, ressalva-se que, em relação ao consumidor, a impossibilidade de pleitear a revisão contratual derivará de uma situação em que ele, devidamente informado, de forma única e exclusiva, tenha dado causa à alteração das circunstâncias.

\footnotetext{
576 MARINONI, Luiz Guilherme; MITIDIERO, Daniel. Código de Processo Civil Comentado Artigo Por Artigo. 4. ed. São Paulo: Revista dos Tribunais, 2012. p. 336.

${ }^{577}$ Apelação 32158-0/2009. $2^{a}$ Câmara Cível. Relatora Maria do Socorro Barreto Santiago. J. 04.08.2009.

${ }^{578}$ Apelação Cível n. ${ }^{\circ}$ 70026513424, Décima Quarta Câmara Cível, Tribunal de Justiça do Rio Grande do Sul, Relator: Niwton Carpes da Silva, J. 02.06.2011.
} 
$\mathrm{Na}$ relação consumerista ganha destaque a questão relativa à impossibilidade de o consumidor adimplir a obrigação em razão de um problema pessoal, como, por exemplo, perda do emprego, sendo que alguns autores são favoráveis à invocação deste evento superveniente para a revisão do contrato. Até mesmo o superendividamento do consumidor vem respaldando a revisão contratual ${ }^{579}$.

Segundo Otávio Luiz Rodrigues Júnior, a moderna doutrina alemã vem considerando que

[...] o elevado grau de vulnerabilidade e de hipossuficiência do consumidor em determinadas atividades econômicas e a falta de controle objetivo das ofertas de bens e serviços, mormente por técnicas abusivas de concessão de crédito, abrem as portas a que a exceção da ruína seja aceita, ainda que de modo excepcional. ${ }^{580}$

Nesse sentido é o posicionamento de Fernando Costa de Azevedo, afirmando que a possibilidade de invocação da circunstância pessoal do consumidor

[...] contrasta com a tradicional doutrina civilista, a qual considera que a revisão ou resolução contratual por onerosidade excessiva tem cabimento apenas em situações que alcancem a coletividade, como as que motivaram as ações revisionistas nos contratos de leasing. ${ }^{581}$

A diferença no tratamento entre os dois sistemas está justamente na ideia de

\footnotetext{
${ }^{579}$ Exemplos: 1) TUTELA ANTECIPADA. CONTRATO DE EMPRÉSTIMO. DESCONTO EM CONTACORRENTE. SALÁRIO. LIMITAÇÃO. PERCENTUAL. 1. Estão presentes os requisitos para concessão de tutela antecipada que visa a limitação dos descontos em conta na qual o cliente recebe salário. 2. Diante da modificação das circunstâncias, o cliente passou a receber pouco mais de duzentos reais, mas as parcelas dos descontos superam quatrocentos reais. Para evitar superendividamento, o contratante pretende a renegociação das cláusulas contratuais e limitação dos descontos. 3. Em razão do caráter alimentar do salário, da necessidade de se garantir a dignidade da pessoa humana do devedor, e tendo em vista o valor por ele percebido mensalmente, defere-se a tutela para limitar o desconto a $20 \%$ do valor líquido recebido, tal como requerido. 4 . Recurso provido. (Tribunal de Justiça do Estado de São Paulo. 14 ${ }^{\mathrm{a}}$ Câmara de Direito Privado. Comarca de São Paulo. Agravo de Instrumento n. 0037450-60.2012.8.26.0000. Relator Melo Colombi. Julgamento: 28.03.2012); 2) APELAÇÃO CÍVEL. AÇÃO COMINATÓRIA. LITIMAÇÃO EM 30\% DOS DESCONTOS EM FOLHA. CABIMENTO. 1. A situação de consumidores que vem sendo denominada de "superendividamento" não é nova e há algum tempo vem sendo tratada com maior sensibilidade na seara judicial. 2. Para estes casos, excepcionalmente, vem-se admitindo a limitação dos descontos realizados em folha de pagamento à margem de $30 \%$ da receita líquida, como forma de efetivação do princípio da dignidade da pessoa humana, ou seja, a fim de possibilitar que a parte disponha minimamente de seus vencimentos para gerir suas finanças e não comprometa o atendimento de suas necessidades básicas. Apelação provida. (Apelação Cível No 70046848172, Décima Nona Câmara Cível, Tribunal de Justiça do RS, Relator: Eugênio Facchini Neto, Julgado em 27.03.2012).

580 RODRIGUES JÚNIOR. Otávio Luiz. Revisão judicial dos contratos: Autonomia da Vontade e Teoria da Imprevisão. São Paulo: Atlas, 2006. p. 115.

${ }^{581}$ COSTA DE AZEVEDO, Fernando. Os desequilíbrios gerados por vantagem e onerosidade excessivas no Direito do Consumidor e a possibilidade de aplicação do Diálogo das fontes entre Código de Defesa do Consumidor e Código Civil 2002. In: MARQUES, Cláudia Lima (Coord.). Diálogo das fontes. Do conflito à coordenação de normas do direito brasileiro. São Paulo: Revista dos Tribunais. 2012, p. 329.
} 
vulnerabilidade do consumidor, que muitas vezes se vê pressionado a consumir, bem como diante de vasta oferta de crédito e dos métodos agressivos de publicidade ${ }^{582}$. Já a relação paritária, por óbvio, pressupõe uma igualdade entre as partes contratantes, inviabilizando indagações de ordem subjetiva para possibilitar a revisão por alteração das circunstâncias, enveredando para um caminho de insegurança jurídica, diante dos numerosos negócios jurídicos firmados na sociedade pós-moderna. Nesta ordem, é inviável um diálogo entre o Direito do Consumidor e o Direito Civil.

\subsubsection{Opção entre revisão e resolução}

Importante também ressaltar que o já citado artigo $6^{\circ}$, inciso $\mathrm{V}$, faz menção à modificação das cláusulas contratuais ou a revisão do contrato, o que difere também do texto do Código Civil, que faz referência, primeiramente, à hipótese de resolução do contrato e, de forma secundária, à revisão do contrato, embora já se tenha discorrido anteriormente que esta última seja a opção que melhor atende aos princípios contratuais vigentes.

Verifica-se que, na relação consumerista, é reconhecido o direito básico do consumidor à modificação da "cláusula que estabeleça prestação desproporcional, mantendose íntegro o contrato que se encontra em execução, ou de obter a revisão do contrato se sobrevierem fatos que tornem as prestações excessivamente onerosas para o consumidor" ${ }^{2583}$. Não se trata, por certo, de um direito a desonerar-se da prestação por meio da resolução do contrato, como afirma Nelson Nery Júnior. ${ }^{584}$

É possível afirmar-se presente o diálogo de influência da legislação especial no sistema previsto para a relação paritária, primando-se pela conservação dos contratos, tornando-os úteis às partes que certamente enveredaram esforços para celebrá-lo com a expectativa de que produzisse efeitos. Assim, a modificação do contrato atenderá melhor aos interesses dos contratantes do que a sua simples resolução, conforme já exposto no item 5.4 do capítulo anterior.

Entretanto, segundo Francisco Paulo de Crescenzo Marino ${ }^{585}$, havendo conflito entre o princípio da conservação dos negócios jurídicos e a regra da interpretação mais favorável ao consumidor, "tida como fundamentada na boa-fé", esta deverá prevalecer. Assim, afirma o

\footnotetext{
${ }^{582}$ MARQUES, Cláudia Lima. Contratos no Código de Defesa do Consumidor. São Paulo: RT, 2002. p. 284.

${ }^{583}$ NERY JÚNIOR. Nelson. Código de Defesa do Consumidor Comentado pelos Autores do Anteprojeto. 7. ed. Rio de Janeiro: Forense Universitária, 2001. p. 479.

${ }^{584}$ Loc. cit.

585 MARINO, Francisco Paulo de Crescenzo. Interpretação do negócio jurídico. São Paulo: Saraiva, 2011. p. 336.
} 
autor, caso a interpretação mais favorável ao consumidor resultar na nulidade da cláusula contratual ou mesmo do negócio jurídico como um todo, deverá ser essa a interpretação prevalecente.

\subsubsection{Contratos de consumo passíveis de revisão/resolução}

O Código de Defesa do Consumidor não faz qualquer limitação quanto a que contratos seriam passíveis de revisão contratual em razão de fato superveniente que traga desequilíbrio contratual. Assim, Giulianna Bonnano Schunck afirma ser incongruente com as regras desse codex "qualquer tipo de limitação à aplicação do artigo $6^{\circ}, \mathrm{V}$, seja aos aleatórios, unilaterais etc., sendo que o campo de aplicação do artigo deve ser irrestrito a todos os contratos". 586

De forma semelhante, Otávio Luiz Rodrigues Júnior afirma que os efeitos da teoria da onerosidade excessiva podem incidir sobre qualquer contrato de consumo e que isto se dá "por influência do princípio da interpretação mais favorável ao consumidor", prevista no artigo 47 do Código de Defesa do Consumidor. Assim, afirma este autor que

[...] qualquer contrato de consumo (unilateral ou bilateral, comutativo e oneroso) pode sofrer os efeitos da teoria da onerosidade excessiva, o que se dá por influência do princípio da interpretação mais favorável ao consumidor (art. 47, CDC). Quanto aos aleatórios, mantém-se a restrição genérica aos mesmos, com a ressalva de que podem ocorrer alterações circunstanciais na execução das cláusulas de cunho não aleatório. ${ }^{587}$

Segundo o autor, a justificativa para essa amplitude no suporte negocial está: i) a natureza protetiva do direito especial e sua decorrência lógica, o princípio da vulnerabilidade; ii) a existência, em todos os contratos de consumo, de um sinalagma amplo, que não se acomoda aos padrões tradicionais da comutatividade, o que deriva do princípio do equilíbrio contratual no Direito do Consumidor; iii) o número significativo de contratos unilaterais envolvendo questões de consumo, "especialmente no âmbito das relações bancárias, o que torna indispensável o concurso de suas regras para tutelá-los". 588

Sérgio Cavalieri Filho ${ }^{589}$, entretanto, afirma que o instituto da onerosidade excessiva

\footnotetext{
${ }^{586}$ SCHUNCK, Giuliana Bonanno. A onerosidade excessiva superveniente no Código Civil: críticas e questões controvertidas. São Paulo: LTR, 2010. p. 144.

${ }^{587}$ RODRIGUES JÚNIOR. Otávio Luiz. Revisão judicial dos contratos: Autonomia da vontade e teoria da imprevisão. São Paulo: Atlas, 2006. p. 207.

${ }^{588}$ Loc. cit.

${ }^{589}$ CAVALIERI FILHO, Sérgio. Programa de direito do consumidor. 3. ed. São Paulo: Atlas, 2011. p. 125.
} 
não se aplica aos contratos aleatórios, com o que não concordamos, considerando-se que a alteração das circunstâncias pode recair em álea que não é a normal do contrato, conforme já exposto no item 5.3 do capítulo anterior.

Não fazendo o CDC qualquer limitação a quais contratos seriam passíveis de revisão por alteração das circunstâncias, nem mesmo exigindo que sejam de execução continuada, sucessiva ou diferida, como faz o Código Civil, verifica-se a preocupação do legislador com o equilíbrio contratual de forma mais ampla na relação consumerista. Considerando-se o imperativo de fazer-se uma interpretação mais favorável ao consumidor, impossível a ocorrência de um "diálogo" entre o Código Civil e o Código de Defesa do Consumidor, porque aquele sistema traz desvantagens ao consumidor, que veria limitado o seu direito de rever determinados contratos buscando o equilíbrio contratual.

6.3.8 Desnecessidade de extrema vantagem para a outra parte para a revisão do contrato de consumo

O Código de Defesa do Consumidor, em seu artigo $6^{\circ}$, inciso V, ao tratar do desequilíbrio contratual causado por evento superveniente, não faz qualquer menção à necessidade ocorrência de "extrema vantagem para a outra parte"590, o que é expressamente exigido pela redação do artigo 478 do Código Civil. Na relação paritária, embora o Código Civil tenha exigido este requisito, conhecido como "efeito gangorra", há grande crítica por parte da doutrina, conforme assinalado no item 5.1.4 do capítulo V, pois nem sempre da desvantagem de uma parte, surge uma vantagem para a outra.

Em sendo tal requisito criticado na relação civil, com mais força de razão o será na relação consumerista, onde é reconhecida a vulnerabilidade do consumidor, parte mais fraca no negócio firmado e ainda em se considerando a questão relativa aos riscos do negócio firmado, que na relação de consumo, recaem sobre o fornecedor. Impossível, portanto, um diálogo entre os dois sistemas.

Neste sentido, Otávio Luiz Rodrigues Júnior afirma que não se exige que "a parte não prejudicada, no caso o fornecedor, também aufira uma vantagem correspondente". 591

\footnotetext{
${ }^{590}$ Não obstante a inexigência da vantagem para a parte contrária na relação consumerista, há julgados que fazem menção a este requisito, ao meu ver, de forma equivocada. Nesse sentido: Apelação Cível n. 9118053 40.2007.8.26.0000 do TJSP.

${ }^{591}$ CUNHA, Wladimir Alcibíades Marinho Falcão. Revisão judicial dos contratos: do Código de Defesa do Consumidor ao Código Civil de 2002. São Paulo: Método, 2007. p. 227.
} 


\subsubsection{Legitimidade ativa para a demanda revisionista / resolutória}

Como visto anteriormente, na relação paritária, a demanda revisionista/resolutória pode ser interposta por qualquer das partes contratantes. Em matéria consumerista, a legitimidade para a propositura da demanda revisionista, tendo em vista um fato superveniente que torne a prestação desproporcional ou excessivamente onerosa, cabe, segundo Nelson Borges ${ }^{592}$, apenas ao consumidor. "Só ele poderá pedir adaptação contratual ao novo estado fático caso sua prestação se torne excessivamente onerosa". O autor ainda afirma que o fornecedor, na condição de credor, não terá qualquer direito à revisão do pacto, pois o Código de Defesa do Consumidor destina-se à defesa do consumidor e que, além disso, o credor jamais veria a sua obrigação "tornar-se excessivamente onerosa, uma vez que ônus é encargo exclusivo do devedor, nunca do credor". 593

Neste sentido também se posiciona Leonardo de Medeiros Garcia ${ }^{594}$, para quem

Os direitos contemplados pelo código são somente para proteção do ser vulnerável (consumidor), não podendo ser utilizado pelo fornecedor a seu favor. Assim, a título de exemplo, o fornecedor não poderá suscitar o art. $6^{\circ}$, $\mathrm{V}$, para solicitar a modificação ou a revisão do contrato, causando prejuízos ao consumidor. ${ }^{595}$

Giuliana Bonnano Schunck, por seu turno, afirma que o Código de Defesa do consumidor é "claríssimo em outorgar tais direitos apenas ao consumidor, que é, na verdade, o tutelado pelo microssistema consumerista". 596

Considerando-se a lógica do sistema consumerista consistente na "tutela e proteção especial ao sujeito consumidor", bem como o entendimento de que o método do diálogo das fontes "não deve ser usado para retirar direitos do consumidor", mas apenas a favor do sujeito vulnerável, sob pena de transformar-se em analogia in pejus ${ }^{597}$, deve-se compreender que a revisão/resolução do contrato por alteração das circunstâncias e que leve a prestações

\footnotetext{
${ }^{592}$ BORGES, Nelson. Teoria da imprevisão no Direito Civil e no Processo Civil. São Paulo: Malheiros, 2002. p. 388.

${ }^{594}$ GARCIA, Leonardo de Medeiros. Direito do consumidor: código comentado e jurisprudência. Niterói: Impetus. $8^{a}$ ed., 2012. p. 69.

${ }^{595} \mathrm{O}$ Superior Tribunal de Justiça também já se posicionou neste sentido: “O art. 6, V, do CDC, disciplina, não uma obrigação, mas um direito do consumidor à modificação de cláusulas consideradas excessivamente onerosas ou desproporcionais. Assim, referida norma não pode ser invocada pela administradora de consórcios para justificar a imposição de modificação no contrato que gere maiores prejuízos ao consumidor (REsp 1269632/MG, Relatora Ministra Nancy Andrighi, $3^{\text {a }}$ Turma, Publicação 03.11.2011).

${ }^{596}$ SCHUNCK, Giuliana Bonanno. A onerosidade excessiva superveniente no Código Civil: críticas e questões controvertidas. São Paulo: LTR, 2010. p. 144.

${ }^{597}$ MARQUES, Cláudia Lima. Contratos no Código de Defesa do Consumidor. São Paulo: RT, 2002. p. 728.
} 
excessivamente onerosas somente pode ser interposta pelo consumidor, tornando inviável um diálogo entre o Direito Civil e o Direito do Consumidor, pois prejudicaria o consumidor, sujeito de direitos que o CDC visa proteger.

6.3.10 A questão da possibilidade de inserção de cláusula impeditiva de revisão contratual por alteração das circunstâncias e cláusula de renegociação

Quanto à possibilidade de inserção de uma cláusula que impeça a revisão ou a modificação do contrato por alteração das circunstâncias, reitera-se posicionamento já citado, no sentido de que, na relação consumerista, em razão do disposto no artigo 51, incisos I e IV do Código de Defesa do Consumidor, tal cláusula seria considerada abusiva, portanto, nula de pleno direito, o que não ocorre na relação paritária.

Também o artigo 51, parágrafo $1^{\circ}$, inciso III, presume como exagerada a vantagem que "se mostra excessivamente onerosa para o consumidor, considerando-se a natureza e conteúdo do contrato, o interesse das partes e outras circunstâncias peculiares do caso".

Não fosse desta forma, restaria quebrado o equilíbrio contratual, "pois bastaria o fornecedor inserir cláusulas que eximissem e/ou atenuassem sua responsabilidade (já que a maioria dos contratos é de adesão), para que o consumidor ficasse desprotegido". ${ }^{598}$ Uma exceção à regra, entretanto, é contemplada no Código de Defesa do Consumidor, ao prever na parte final do inciso citado que "Nas relações de consumo entre o fornecedor e o consumidor pessoa jurídica, a indenização poderá ser limitada, em situações justificáveis”.

Em regra, na relação consumerista, os riscos do contrato são todos do fornecedor, que não poderá transferi-los aos consumidores "por nenhuma manifestação válida de vontade". 599 O risco é considerado por Rizzatto Nunes uma das principais características da atividade econômica. Segundo o autor, na

[...] livre iniciativa, a ação do empreendedor está aberta simultaneamente ao sucesso e ao fracasso. A boa avaliação dessas possibilidades por parte do empresário é fundamental para o investimento. Um risco mal calculado pode levar o negócio à bancarrota. Mas o risco é dele. ${ }^{600}$

A alocação dos riscos da imprevisão exclusivamente ao fornecedor expressa,

\footnotetext{
598 GARCIA, Leonardo de Medeiros. Direito do consumidor: código comentado e jurisprudência. Niterói: Impetus, $8^{\text {a }}$ ed., 2012. p. 368.

${ }^{599}$ MARQUES, Cláudia Lima. Contratos no Código de Defesa do Consumidor. São Paulo: RT, 2002. p. 272.

${ }^{600}$ NUNES, Rizzatto. Curso de Direito do Consumidor. 7. ed. São Paulo: Saraiva, 2012. p. 216.
} 
segundo Gustavo Tepedino, a igualdade substancial pretendida atingir pelo legislador constituinte, "como forma de reduzir as desigualdades econômicas". ${ }^{601}$ Também Rizzatto Nunes afirma que, para a revisão do contrato por alteração das circunstâncias, basta que após a sua celebração surjam fatos que o tornem excessivamente oneroso, não sendo necessária a previsibilidade destes fatos. Isto decorreria do fato de que o fornecedor "assume integralmente o risco de seu negócio e que detêm o conhecimento técnico para implementá-lo e oferecê-lo no mercado."

No mesmo sentido, Bruno Miragem afirma que o Código de Defesa do Consumidor impede a transferência dos riscos inerentes ao negócio do fornecedor ao consumidor. ${ }^{603}$

Tepedino, entretanto, ressalva que a regra não pode excluir a incidência para o consumidor de riscos normais de certos negócios jurídicos, quando estiver "devidamente informado". ${ }^{604}$ A vedação do Código de Defesa do Consumidor a que se insira uma cláusula que implique renúncia a um direito do consumidor, no caso, o direito à revisão do contrato, beneficia o consumidor. Com isso, um diálogo entre o Direito Civil e o Direito do Consumidor também seria inviável.

O Código Civil brasileiro, conforme exposto no item 5.8, não faz menção à chamada cláusula de renegociação, engendrada pelas próprias partes contratantes, tendo por objeto a “obrigação de renegociar um contrato sempre que, por efeito de uma alteração das circunstâncias vigentes ao tempo da sua celebração, se verifica uma modificação substancial do equilíbrio das posições das partes, por estas estabelecido". ${ }^{605}$ Apesar da omissão legislativa, considerando-se a autonomia privada, bem como a função social dos contratos, é de se entender que uma cláusula dessa é admitida no Direito Civil brasileiro.

Quanto à cláusula de renegociação, consistente na "obrigação de renegociar um contrato sempre que, por efeito de uma alteração das circunstâncias vigentes ao tempo da sua celebração, se verifica uma modificação substancial do equilíbrio das posições das partes, por estas estabelecido" "606, entende-se que no Direito do Consumidor não é necessária, pois a modificação do contrato é considerado um direito básico do consumidor, conforme dispõe o

\footnotetext{
${ }^{601}$ TEPEDINO, Gustavo. A aplicabilidade do Código Civil nas relações de consumo: diálogos entre o Código Civil e o Código de Defesa do Consumidor. In: LOTUFO, Renan; MARTINS, Fernando Rodrigues (Org). 20 anos do Código de Defesa do Consumidor: conquistas, desafios e perspectivas. São Paulo: Saraiva, 2011, p. 80 .

${ }^{602}$ NUNES, Rizzatto. Comentários ao Código de Defesa do Consumidor. 2.ed. São Paulo: Saraiva, 2005, p. 519.

${ }^{603}$ MIRAGEM, Bruno. Direito do Consumidor. São Paulo: Revista dos Tribunais, 2008. p. 128.

${ }^{604}$ TEPEDINO, Gustavo. Op. cit., p. 82.

${ }^{605}$ CARVALHO FERNANDES, Luís A. A teoria da imprevisão no Direito Civil Português.Lisboa: Quid Juris?, 2001. p. 273.

${ }^{606}$ Ibid., p. 316.
} 
já citado artigo 6, inciso V do Código de Defesa do Consumidor.

Já Fernando Costa de Azevedo entende que ela seria uma subespécie de dever de cooperação fundado na boa-fé objetiva ${ }^{607}$ - "para evitar a "ruína econômica" do consumidor em situação de superendividamento". 608

Também Cláudia Lima Marques analisa o dever de renegociação. A autora aborda a questão dos contratos cativos de longa duração, os quais envolvem uma "cadeia de fornecedores organizados entre si e com uma característica determinante: a posição de "catividade" ou "dependência" dos clientes, consumidores". ${ }^{609}$ Como exemplo, temos os contratos de seguro-saúde, de assistência médico-hospitalar, de previdência privada, de uso de cartão de crédito, telefone, TV a cabo, fornecimento de água e luz, entre outros.

Nesses contratos, haveria um "novo imperativo", qual seja a visualização deste continuum e da conexidade dos vínculos e deveres no tempo, "requerendo cooperação renegociadora contínua em matéria de contratos de longa duração". A autora afirma ainda que a doutrina alemã

[...] com base nos deveres de cooperação, da boa-fé, e na antiga exceção da ruína, está ativamente estudando a existência de um dever geral de renegociação dos contratos de longa duração. Partindo da premissa de que há uma cláusula ou um dever de modificação de boa-fé (no caso brasileiro, com previsão expressa no art. $6^{\circ}, \mathrm{V}$, do CDC) dos contratos de longa duração, sempre que há quebra da base objetiva do negócio (Wegfall der Geschäftsgrundlage) e onerosidade excessiva daí resultante, considera parte majoritária da doutrina que haveria uma espécie de dever ipso jure de adaptação (ipso jure-Anpassungspflicht) ou dever de antecipar e cooperar na adaptação, logo, dever (ou para alguns Obligenheit) de renegociar

\footnotetext{
${ }^{607}$ O Tribunal de Justiça do Estado de São Paulo já decidiu: "Plano de saúde coletivo - Cláusula de revisão por sinistralidade - Pretensão de anulação - Inviabilidade - Mecanismo válido de preservação do sinalagma ou do equilíbrio entre prestações recíprocas e interdependentes - A revisão por sinistralidade tem relação com onerosidade excessiva que autoriza a renegociação, recomendável por dever de cooperação inerente à boa-fé objetiva - Alcançado em prazo a ser ajustado o propósito de compensação do desequilíbrio, a renegociação disporá sobre a retomada dos patamares remuneratórios anteriores, sob pena de o desequilíbrio perpetuar-se não mais em detrimento da operadora, mas agora em prejuízo da sociedade contratante - Se o contrato não for alterado por renegociação, admite-se a denúncia motivada pela operadora com base na onerosidade excessiva Caso, porém, em que a operadora, frustrada a renegociação, em vez de denunciar o contrato, impôs unilateralmente aumento por sinistralidade superior até mesmo ao índice por ela calculado - Inadmissibilidade - Exercício abusivo de faculdade contratual - Nulidade absoluta do aumento na mensalidade - Ação procedente em parte - Petição inicial indeferida de ofício quanto a índice de correção monetária por falta de litígio e, consequentemente, de interesse processual - Apelação provida em parte. (Apelação n. 906849502.2007.8.26.0000, 10a Câmara de Direito Privado, Relator. Guilherme Santini Teodoro, Comarca de São Paulo, Julgamento em 13.04.09).

${ }^{608}$ COSTA DE AZEVEDO, Fernando. Os desequilíbrios gerados por vantagem e onerosidade excessivas no Direito do Consumidor e a possibilidade de aplicação do Diálogo das fontes entre Código de Defesa do Consumidor e Código Civil 2002. In: MARQUES, Cláudia Lima (Coord.). Diálogo das fontes. Do conflito à coordenação de normas do direito brasileiro. São Paulo: Revista dos Tribunais. 2012, p. 345.

${ }^{609}$ MARQUES, Cláudia Lima. Contratos no Código de Defesa do Consumidor. São Paulo: RT, 2002. p. 96.
} 
(Neuverhandlungspflicht). ${ }^{610}$

É importante ressaltar que o artigo 51 , parágrafo $2^{\circ}$ do Código de Defesa do Consumidor revela a intenção do legislador pela manutenção do contrato, ao prever que "A nulidade de uma cláusula contratual abusiva não invalida o contrato, exceto quando de sua ausência, apesar dos esforços de integração, decorrer ônus excessivo a qualquer das partes".

Diante da compreensão de que o dever de renegociação decorre da boa-fé objetiva, bem como diante da concepção da obrigação como um processo e o dever de cooperação à obrigação inerente, é possível falar-se em um diálogo de coordenação e adaptação sistemática através da transposição das conquistas do "Direito dos Juízes" quanto às funções da boa-fé objetiva na relação de consumo para a relação paritária.

${ }^{610}$ MARQUES, Cláudia Lima. Contratos no Código de Defesa do Consumidor. São Paulo: RT, 2002. p. 100101. 


\section{CONCLUSÃO}

Não é incomum que um contrato, após a sua celebração, tenha o seu equilíbrio afetado pela alteração das circunstâncias negociais, sendo que há inúmeros séculos a temática vem sendo debatida, buscando-se a melhor solução para os conflitos de interesse dela decorrentes.

Parece evidente que o ideal seria que as próprias partes contratantes dispusessem sobre as consequências da alteração das circunstâncias. Entretanto, nem sempre é possível prever o que causará o desequilíbrio contratual e nem mesmo a dimensão de suas consequências.

O Código de 1916, fortemente influenciado pelos ideais liberalistas e individualistas do Código Napoleônico, não contemplou a possibilidade de resolução ou revisão contratual em razão de evento superveniente à sua celebração que o tornasse desequilibrado. Entretanto, com o passar do tempo, principalmente com advento das Grandes Guerras mundiais, veio à tona uma preocupação com a dignidade da pessoa humana, o que se refletiu nos contratos, pois não mais se admitia relações espoliativas, abusivas e iníquas.

A dignidade da pessoa humana foi erigida a fundamento da República Federativa do Brasil no artigo $1^{\circ}$, inciso III da Constituição Federal de 1988. Além disto, esta Carta prescreveu como fundamentos da República (artigo $3^{\circ}$ ) a "construção de uma sociedade livre, justa e solidária" (inciso I) e a erradicação da pobreza e da marginalização e redução das desigualdades sociais e regionais (inciso II). Com isso, a legislação pátria até então vigente mostrava-se desatualizada e incompatível com a sistemática solidarista da atualidade.

Em matéria contratual, os princípios clássicos como autonomia da vontade, obrigatoriedade, relatividade e boa-fé receberam um releitura, ao passo que outros foram acrescentados, como a função social do contrato e o equilíbrio contratual.

Atualmente, em razão da solidariedade, da socialidade e da dignidade da pessoa humana que se impõe às relações jurídicas, o Estado passou a intervir de forma crescente nos contratos, e até mesmo antes da entrada em vigor do Código Civil de 2002, o Código de Defesa do Consumidor brasileiro, datado de 1990, materializou a preocupação do legislador constituinte com aquele que é peça-chave na economia brasileira - o consumidor, reconhecidamente a parte mais fraca da relação contratual. Por ser a parte mais fraca da relação contratual, o legislador outorgou inúmeros mecanismos para a sua proteção, tais como a inversão do ônus da prova, a declaração de nulidade das cláusulas consideradas abusivas e a 
possibilidade de revisão dos contratos em que haja um desequilíbrio contratual decorrente de um fato superveniente à sua celebração (ausência de sinalagma funcional).

Não obstante o equilíbrio contratual afetado pela alteração das circunstâncias venha sendo discutido na história desde a Antiguidade, como examinado no Capítulo III, culminando com inúmeras propostas doutrinárias, algumas delas retratadas no Capítulo IV, muitas dúvidas ainda remanescem na sistemática brasileira quanto à interpretação de dispositivos contidos na legislação paritária, mormente nos artigos 478 a 480 do Código Civil, os quais, não raro, conflitam com dispositivos pertinentes à matéria contidos do Código de Defesa do Consumidor.

No presente estudo, constatou-se que a solução dos conflitos de interesses decorrentes de alteração das circunstâncias nem sempre é fácil e que a disciplina dada pelo Código Civil não é isenta de críticas. Diante do conflito existente entre a sistemática contida no Código Civil e no Código de Defesa do consumidor, analisou-se a possibilidade de aplicação da teoria do "diálogo das fontes" de Erik Jayme, por intermédio dos três diálogos possíveis propostos por este autor: i) diálogo sistemático de coerência; ii) diálogo sistemático de complementaridade; iii) diálogo de influências recíprocas.

Tendo em vista que o direito do consumidor é considerado um direto fundamental e que o "diálogo" preponderante entre o Código Civil e o Código de Defesa do Consumidor consiste na promoção pelo julgador dos direitos do consumidor, bem como o Leitmotiv da teoria da Erik Jayme, que seria os direitos humanos, busca-se uma interpretação entre os dois sistemas de forma a harmonizá-los, favorecendo uma interpretação mais benéfica ao consumidor. A partir da teoria de Jayme, foram analisadas semelhanças e diferenças entre o Código de Defesa do Consumidor e o Código Civil, apontando-se eventual diálogo.

Um problema tormentoso para a doutrina civilista está em delimitar em que consiste uma prestação "excessivamente onerosa", pois o legislador não trouxe elementos objetivos para a sua aferição. Como exposto em outra sede, é certo que não será uma "simples dificuldade", como mencionado por Giuliana Bonanno Schunck ${ }^{611}$, que acarretará uma onerosidade excessiva, sendo necessário que a alteração tenha "magnitude" e seja "grande o suficiente para que ocorra o desequilíbrio na prestação". 612

Para solucionar o problema, vale rememorar os critérios sobre os quais se discorreu

\footnotetext{
${ }^{611}$ SCHUNCK, Giuliana Bonanno. A onerosidade excessiva superveniente no Código Civil: críticas e questões controvertidas. São Paulo: LTR, 2010. p. 87.

${ }^{612}$ CARVALHO FERNANDES, Luís A. A teoria da imprevisão no Direito Civil português. Lisboa: Quid Juris?, 2001. p. 107.
} 
no item 5.1.2, do Capítulo V, e mencionados por Laura Coradini Frantz ${ }^{613}$, ancorada em Laurence Fin-Langer, quais sejam: reciprocidade de direitos e de obrigações; comutatividade; equivalência e proporcionalidade. Além destes critérios, a proibição de enriquecimento sem causa, a função social do contrato e a distribuição de ônus e riscos são citados por Fernando Rodrigues Martinss ${ }^{614}$ na busca de solução de situações injustas nas relações jurídicas contratuais.

Todos estes critérios podem ser utilizados, sem que, abstratamente, haja a prevalência de um sobre o outro, mas que ao contrário, aplicados de forma conjunta ao caso concreto, possam abranger a riqueza e as vicissitudes da vida negocial, atualmente tão massificada e diversificada, sempre buscando a solução mais justa.

Sob este aspecto, é possível vislumbrar-se um diálogo de influência sistemática do Direito Civil sobre o Direito do Consumidor através da utilização destes critérios para a aferição da onerosidade excessiva na relação de consumo, desde que a sua aplicação implique a proteção do consumidor, favorecendo-o por intermédio de uma interpretação mais benéfica.

Por outro lado, o Código de Defesa do Consumidor traz algumas presunções de ocorrência de "vantagem exagerada", as quais podem servir de diretrizes para a aplicação do disposto no artigo 478 do Código Civil, quando menciona a expressão "extrema vantagem para a outra parte", em um verdadeiro diálogo sistemático de coerência. O CDC também influencia a interpretação do Código Civil ao optar, preferencialmente, pela revisão do contrato e não pela resolução, o que certamente atenderá melhor aos interesses das partes e à própria função social do contrato.

O imperativo principiológico de equilíbrio na relação contratual não parece compatibilizar-se com a exigência da imprevisibilidade do evento superveniente, como o fez o artigo 478 do Código Civil, que é, inclusive, objeto de projeto de lei objetivando alterar a sua redação, e que não é exigido, por exemplo, na Alemanha, reconhecidamente um dos países mais avançados em se tratando de Direito Civil. Mesmo porque, são relevantes também na apreciação do desequilíbrio contratual os efeitos que o evento superveniente, ainda que previsível, possam acarretar e que nem sempre podem ser dimensionados antecipadamente, a exemplo do que ocorre com a inflação. Com isso, ganha destaque o Código de Defesa do Consumidor que, não faz menção à imprevisibilidade ou extraordinariedade do evento que torna a prestação excessivamente onerosa, preocupando-se apenas com a equivalência nas

\footnotetext{
${ }^{613}$ FRANTZ, Laura Coradini. Revisão dos contratos: elementos para sua construção dogmática. São Paulo: Saraiva, 2007. p. 115.

${ }^{614}$ MARTINS, Fernando Rodrigues. Princípio da justiça contratual. São Paulo: Saraiva, 2009. p. $269-273$.
} 
prestações. Nesta seara, não é possível um diálogo entre o sistema paritário e o consumerista, pois este apresenta uma norma mais flexível e favorável aos consumidores.

É evidente que na relação consumerista, em que a vulnerabilidade é um atributo inerente ao consumidor, a questão atinente aos riscos negociais, os quais são suportados pelo fornecedor, torna mais clara a possibilidade de revisão do contrato em favor daquele. Enquanto isto, a relação paritária, tanto a lei, quanto o contrato podem alocar de forma diversa os ônus e riscos contratuais, o que demandará uma análise por parte do juiz a fim de determinar as consequências da alteração das circunstâncias.

A exigência contemplada no artigo 478 de que o evento superveniente que torne a prestação excessivamente onerosa para uma parte traga uma "extrema vantagem para a outra parte", no que a doutrina denomina "efeito gangorra", merece reprovação, tanto que já há proposta de modificação legislativa para excluí-la, pois é possível que a onerosidade excessiva para uma parte não implique, necessariamente, uma vantagem ou benefício para a outra ou que até mesmo a vantagem para a outra parte possa ser considerada uma ocorrência normal do negócio firmado, como afirmado por Claudio Luiz Bueno de Godoy ${ }^{615}$.

E não é só. A exigência do "efeito gangorra" demandaria ainda que a parte prejudicada pela onerosidade excessiva arcasse com o ônus processual da prova da ocorrência da vantagem para a parte contrária, dificultando ainda mais atingir-se um equilíbrio contratual. Mais uma vez, um diálogo entre o Código Civil e o Código de Defesa do Consumidor mostrou-se inviável.

Via de regra, para o direito paritário, vem se entendendo que o estado moratório da parte prejudicada pela alteração das circunstâncias impede a revisão/resolução do contrato. Não obstante este entendimento, parece compatível com os preceitos inerentes à boa-fé objetiva que se a mora é decorrente do evento superveniente e que, em prazo razoável após a sua ocorrência seja proposta a respectiva demanda, a mora possa ser relevada. Embora o Código de Defesa do Consumidor não faça qualquer exigência neste sentido, entendo que se há uma cobrança exagerada e incompatível com o contrato ou a lei, a situação moratória do consumidor não obstará a demanda, conforme vem entendendo a jurisprudência.

O sistema civilista não trata da possibilidade ou não de inserção de uma cláusula impeditiva de revisão/resolução, havendo certa divergência na doutrina, parecendo mais acertado o posicionamento de Lotufo e Junqueira de Azevedo, conforme mencionado no item 5.8. do Capítulo V, no sentido de que uma cláusula assim deve ser "específica", sob pena de

\footnotetext{
${ }^{615}$ GODOY, Claudio Luiz Bueno de. A função social do contrato: os novos princípios contratuais. 3. ed. São Paulo: Saraiva, 2009. p. 67.
} 
implicar a renúncia antecipada, uma "previsão do imprevisível", o que seria contraditório. Já o sistema consumerista impede de forma expressa tal cláusula, o que certamente beneficia o consumidor, que, desprovido de conhecimentos técnicos, não tem plenos conhecimentos a respeito do mercado pertinente ao negócio que celebrou, tornando-se inviável um diálogo entre os dois sistemas, posto que prejudicial ao consumidor.

A cláusula de renegociação no Direito do Consumidor, por intermédio do que Jayme denomina "Direito dos Juízes", é considerada um corolário da boa-fé objetiva informadora dos contratos. Apesar do silêncio do legislador em matéria de Direito Civil, entendo possível um diálogo de coordenação e adaptação sistemática através da transposição das conquistas do "Direito dos Juízes" para a relação paritária.

De todos os temas abordados no decorrer do presente trabalho, constatou-se que vários aspectos deverão ser analisados para a apuração do equilíbrio contratual, não sem antes definir-se se a relação é paritária ou de consumo, conforme o que, abordar-se-á: i) a previsibilidade ou não do evento superveniente; ii) se o evento superveniente encontra-se na álea normal do contrato; iii) se possível, a preferência pela revisão do contrato, e não a sua resolução, em razão da aplicação do princípio da conservação do contrato; iv) possibilitandose a revisão, em que ela implicará, ou seja, se um reajustamento do preço, uma dilação do prazo para cumprimento da obrigação, se é uma "variação da prestação ou mesmo de sua modalidade" ${ }^{, 616}$; v) se o desequilíbrio contratual decorre de culpa da parte prejudicada pelo evento superveniente; vi) se o devedor já se encontrava moroso por ocasião do evento superveniente à celebração que causou desequilíbrio contratual e se isto impedirá ou não a revisão/resolução contratual; vii) se a revisão do contrato implicará em prejuízos para a contraparte a fim de que não haja mera transferência de prejuízos; ix) a distribuição dos riscos contratuais; $x$ ) qual a magnitude do desequilíbrio contratual (se a parte está diante de uma mera dificuldade no cumprimento da prestação assumida).

Como afirma Claudio Luiz Bueno de Godoy,

Em resumo, o que se pode dizer, nos limites da menção ao problema da alteração
das circunstâncias, é que, sem dúvida, à sua análise, ou à análise de sua relevância,
não se deve abrir mão da consideração simultânea, frise-se, de elementos como a
anormalidade dos fatos, fora do risco coberto pelo ajuste, que o desequilibrem, de
modo a fazer inexigível, conforme os parâmetros da boa-fé objetiva, e porque
afetada a causa, o sinalagma do contrato, a prestação da outra parte, nos moldes em
que pactuada. E, mais, sem que seja necessariamente identificável um critério ou
baliza rígidos a nortear a decisão. Trata-se, na verdade, de uma decisão informada
pela tensão e, pois, pela ponderação dos elementos da autonomia privada, como

${ }^{616}$ GODOY, Claudio Luiz Bueno de. A função social do contrato: os novos princípios contratuais. 3. ed. São Paulo: Saraiva, 2009. p. 150. 
cristalizados no contrato, e da boa-fé, como forma de adaptação da entabulação - e preservação de seu equilíbrio - à alteração da realidade. ${ }^{617}$

Certo é que, tanto o Código Civil quanto o Código de Defesa do Consumidor devem, segundo Gustavo Tepedino, atender às finalidades pretendidas pelo legislador constituinte para suas respectivas áreas de atuação, considerando-se as características subjetivas de seus centros de interesse, "informados pelos princípios e valores constitucionais que, assegurando a unidade do sistema, graduam os níveis de tutela de acordo com as singularidades jurídicas sobre as quais incidem". 618

${ }^{617}$ GODOY, Claudio Luiz Bueno de. A Função Social do Contrato: os novos princípios contratuais. 3. ed. São Paulo: Saraiva, 2009. p. 62.

${ }^{618}$ TEPEDINO, Gustavo. A aplicabilidade do Código Civil nas relações de consumo: diálogos entre o Código Civil e o Código de Defesa do Consumidor. In: LOTUFO, Renan; MARTINS, Fernando Rodrigues (Coord.). 20 anos do Código de Defesa do Consumidor: conquistas, desafios e perspectivas. São Paulo: Saraiva, 2011. p. 88. 


\section{REFERÊNCIAS}

ABREU, José. O negócio jurídico e sua teoria geral. São Paulo: Saraiva, 1988.

AGUIAR JÚNIOR, Ruy Rosado. Extinção dos contratos por incumprimento do devedor. Rio de Janeiro: AIDE, 2003.

ALVIM, Agostinho. Da inexecução das obrigações civis e suas conseqüências. São Paulo: Jurídica e Universitária, 1965.

ARAÚJO, Fernando. Teoria económica do contrato. Coimbra: Almedina, 2007.

ASCENSÃO, José de Oliveira. Alteração das circunstâncias e justiça contratual no novo Código Civil. Revista Trimestral de Direito Civil. São Paulo, Padma, v. 25, p. 93-118, janeiro/março 2006.

AZEVEDO, Álvaro Villaça. Teoria da imprevisão e revisão judicial dos contratos. Revista dos Tribunais, v. 733, p. 109-119, 1996.

O novo Código Civil Brasileiro: tramitação; função social do contrato; boa-fé objetiva; teoria da imprevisão e, em especial, onerosidade excessiva (Laesio enormis). In: TEPEDINO, Gustavo; FACHIN, Luiz Edson (Coord.). O Direito e o Tempo: Embates Jurídicos e Utopias Contemporâneas. Rio de Janeiro: Renovar, 2008.

AZEVEDO, Antônio Junqueira de. Negócio jurídico, existência, validade e eficácia. São Paulo: Saraiva, 1974.

. Negócio jurídico e declaração negocial. São Paulo: Saraiva, 1986.

. Estudos e pareceres de direito privado. São Paulo: Saraiva, 2004.

Novos estudos e pareceres de direito privado. São Paulo: Saraiva, 2009.

AZEVEDO, Marcos de Almeida Villaça. Onerosidade excessiva e desequilíbrio. Tese (Doutorado) - Universidade de São Paulo, São Paulo, 2002.

BARLETTA, Fabiana Rodrigues. A revisão contratual no Código Civil e no Código de Defesa do Consumidor. São Paulo: Saraiva, 2002.

BESSONE, Darcy. Do contrato: Teoria Geral. São Paulo: Saraiva, 1997.

BETTI, Emilio. Teoria geral do negócio jurídico. Campinas: LZN, 2003.

BEZZERRA CAVALCANTI, Franciso de Queiroz. A teoria da imprevisão. Revista Forense, Rio de Janeiro, v. 260, n. 892/894, p. 109-116, 1997.

BIERWAGEN, Mônica Yoshizato. Princípios e regras de interpretação dos contratos no Novo Código Civil. São Paulo: Saraiva, 2003. 
BITTAR, Carlos Alberto. Teoria da imprevisão: dos poderes do juiz. São Paulo: Revista dos Tribunais, 1994.

BORGES, Nelson. A teoria da imprevisão no Direito Civil e no Processo Civil. São Paulo: Malheiros, 2002.

BRANCO, Gerson Luiz Carlos. Função social dos contratos: Interpretação à luz do Código Civil. São Paulo: Saraiva, 2009.

CALVÃO DA SILVA, João. Responsabilidade civil do produtor. Coimbra: Almedina. 1999.

CANALES, Manuel Miranda. Derecho de los contratos. Lima: Cultural Cuzco, 1988.

CARDINI, Eugenio Oswaldo. La teoría de la imprevisión. Buenos Aires: Abeledo-Perrot, 1937.

CARDOSO, Luiz Philipe Tavares de Azevedo. A onerosidade excessiva no Direito Civil Brasileiro. Dissertação (Mestrado) - Universidade de São Paulo, São Paulo, 2010.

CARDOZO, Benjamin N. A natureza do processo judicial. São Paulo: Martins Fontes, 2004.

CARLOMAGNO, Adelqui. Cláusula rebus sic stantibus. Enciclopédia Saraiva do Direito. v. 15. São Paulo: Saraiva, 1977.

CARRESI, Franco. II contrato. Milano: Dott. A. Giuffrè, 1987.

CARRIDE, Norberto Almeida. Vícios do negócio jurídico. São Paulo: Saraiva, 1997.

CARVALHO FERNANDES, Luís A. A teoria da imprevisão no Direito Civil português.

Lisboa: Quid Juris?, 2001.

CASTRO Y BRAVO, Federico. El negocio juridico. Madrid: Civitas, 1997.

CAVALCANTI, Themístocles Brandão. Cláusula “rebus sic stantibus”. São Paulo: Saraiva, 1963.

CAVALIERI FILHO, Sérgio. Programa de Direito do Consumidor. 3. ed. São Paulo: Atlas, 2011.

CODERCH, Pablo Salvador. Alteración de circunstancias en el art. 1213 de la Propuesta de Modernización del Código Civil en materia de Obligaciones y Contratos. Revista para el Análisis del Derecho, Barcelona, Octubre de 2009. Disponível em:

<http://ssrn.com/abstract=1495082>. Acesso em: 03 abr. 2012.

COGO, Rodrigo Barreto. A frustração do fim do contrato. Dissertação (Mestrado) Universidade de São Paulo, São Paulo, 2005.

CORDEIRO, António Manuel da Rocha e Menezes. A boa-fé no Direito Civil. Coimbra: Almedina, 1984. (Colecção Teses, v. 1, T. II). 1999. . A alteração das circunstâncias e o pensamento sistemático. Coimbra: Almedina, 
CORREIA, A. Ferrer. Erro e interpretação na teoria do negócio jurídico. Coimbra: Almedina, 1985.

COSSIO, Carlos. La teoria de la imprevision. São Paulo: Livraria dos Advogados, 1961.

COSTA, Mário Júlio de Almeida. Direito das obrigações. 9. ed. Coimbra: Almedina, 2003.

COSTA DE AZEVEDO, Fernando. Os desequilíbrios gerados por vantagem e onerosidade excessivas no Direito do Consumidor e a possibilidade de aplicação do Diálogo das fontes entre Código de Defesa do Consumidor e Código Civil 2002. In: MARQUES, Cláudia Lima (coord.). Diálogo das fontes: do conflito à coordenação de normas do direito brasileiro. São Paulo: Revista dos Tribunais. 2012.

COUTO E SILVA, Clóvis Veríssimo. A obrigação como processo. São Paulo: Bushatsky, 1976.

A teoria da base do negócio jurídico no Direito Brasileiro. Revista dos Tribunais, v. 655, ano 79, São Paulo, p. 11, 1990.

. A obrigação como processo. Rio de Janeiro: FGV, 2011.

CUNHA, Wladimir Alcibíades Marinho Falcão. Revisão judicial dos contratos: do Código de Defesa do Consumidor ao Código Civil de 2002. São Paulo: Método, 2007.

CUNHA BRUNO, Vânia Maira da. A teoria da imprevisão e o atual direito privado nacional. Rio de Janeiro: Lumen Juris, 1994.

DANZ, Erich. La interpretación de los negocios jurídicos. Madrid: Revista de Derecho Privado, 1955.

DONNINI, Rogério Ferraz. A revisão dos contratos no Código Civil e no Código de Defesa do Consumidor. 2. ed. São Paulo: Saraiva, 2001.

EFING, Antônio Carlos. Fundamento do direito das relações de consumo. 3. ed. Curitiba: Juruá, 2011.

EISENBERG, Melvin A. Impossibility, impracticability and frustration. Journal of Legal Analysis, Winter, 2009, v. 1, n. 1, p. 213. Disponível em <

http://ssrn.com/abstract=1349482>. Acesso em: 24 abr. 2012.

ESPÍNOLA, Eduardo. Cláusula "Rebus sic stantibus" no direito contemporâneo. Revista Forense, Rio de Janeiro: Forense, 1951.

FACHIN, Luis Edson. Repensando fundamentos do Direito Civil brasileiro contemporâneo. Rio de Janeiro: Renovar, 1998.

(Coord.). O Direito e o tempo: embates jurídicos e utopias contemporâneas. Rio de Janeiro: Renovar, 2008.

FERRAZ JUNIOR, Tercio Sampaio. Estudos de Filosofia do Direito: Reflexões sobre o Poder, a Liberdade, a Justiça e o Direito. 3. ed. São Paulo: Atlas, 2009. 
FERREIRA, Carlos Alberto. Equilíbrio contratual. In: LOTUFO, Renan (Coord.). Direito Civil Constitucional. São Paulo: Max Limonad, 1999.

FERREIRA, Durval. Erro negocial - objecto - motivos - base negocial e alterações de circunstâncias. Coimbra: Almedina, 1998.

FERREIRA DE ALMEIDA, Carlos. Texto e enunciado na teoria do negócio jurídico. Coimbra: Almedina, 1992.

FERRI, Luigi. L'autonomia privata. Milão: Giuffrè, 1959.

FILOMENO, José Geraldo Brito. Código de Defesa do Consumidor Comentado pelos Autores do Anteprojeto. 7. ed. Rio de Janeiro: Forense Universitária, 2001.

FLUME, Werner. El negócio jurídico. Madrid: Fundación Cultural del Notariado, 1998.

FONSECA, Arnoldo Medeiros da. Caso fortuito e teoria da imprevisão. Rio de Janeiro: Forense, 1958.

FRANTZ, Laura Coradini. Revisão dos contratos: elementos para sua construção dogmática. São Paulo: Saraiva, 2007.

GALVÃO TELLES, Inocêncio. Manual dos contratos em geral. Coimbra: Coimbra Editora, 2010.

GARCIA, Leonardo de Medeiros. Direito do consumidor: código comentado e jurisprudência. 8. ed. Niterói: Impetus, 2012.

GARRIDO DE PAULA, Luiz Antonio. O desequilíbrio das prestações contratuais. Dissertação (Mestrado) - Universidade de São Paulo, São Paulo, 2000.

GODOY, Claudio Luiz Bueno de. A função social do contrato: os novos princípios contratuais. 3. ed. São Paulo: Saraiva, 2009.

GOLDBERG, Victor P. After frustration: three cheers for Chandler v. Webster. Disponível em: http://ssrn.com/abstract=1703123. Acesso em: 03 abr. 2012.

GOMES, Orlando. Contratos. Rio de Janeiro: Forense, 2007.

GÓMEZ MEJÍA, Fernando. La interpretación del derecho. Bogotá: Ananké, 1979.

GONÇALVES, Carlos Roberto. Direito Civil brasileiro. v. III. 5. ed. São Paulo: Saraiva, 2008.

GUERRA JÚNIOR, Celso Souza. Negócios jurídicos. Curitiba: Juruá, 2005.

IHERING, Rudolf von. A finalidade do direito. Rio de Janeiro: Rio, 1979. A luta pelo direito. Rio de Janeiro: Liber Juris, 1987.

IRTI, Natalino. L'interpretazione del contratto. Milani: Casa Editrice Dott Antonio, 2000. 
ITURRASPE, Jorge Mosset; PIEDECASAS, Miguel A. La revisión del contrato. Santa Fe: Rubinzal Culzoni, 2008.

JEOVÁ SANTOS, Antonio. Função social, lesão e onerosidade excessiva nos contratos. São Paulo: Método, 2002.

KLANG, Márcio. A teoria da imprevisão e a revisão dos contratos. São Paulo: Revista dos Tribunais, 1983.

LARENZ, Karl. Derecho Civil: Parte General. Madrid: Editoriales de Derecho Reunidas, 1978.

Base del negocio juridico y cumplimiento de los contratos. Granada: Editorial Comares, 2002.

LORENZETTI, Ricardo Luís. Fundamentos de Direito Privado. Tradução de Vera Maria Jacob de Fradera. São Paulo: Revista dos Tribunais, 1998.

. Tratado de los contratos. Tomo I. Buenos Aires: Rubinzal - Culzoni, 2004.

LOTUFO, Renan (Coord.). Direito Civil Constitucional. São Paulo: Max Limonad, 1999. (Coord.). Cadernos de autonomia privada. Curitiba: Juruá, 2001.

. Direito Civil avançado. São Paulo: Revista dos Tribunais, 2002. . Código Civil comentado. São Paulo: Saraiva, 2003.

LUCY, William. Philosophy of Private Law. New York: Oxford University, 2007.

MAIA, Paulo Carneiro. Da cláusula rebus sic stantibus. São Paulo: Saraiva, 1959.

MALDONADO, María Carreras. Revisión del contrato por cambio extraordinário. Disponível em: <http://biblio.juridicas.unam.mx/libros/3/1022/6.pdf>. Acesso em: 20 mar. 2012.

MALFATTI, Alexandre. Liberdade contratual. In: LOTUFO, Renan (Coord.). Cadernos de autonomia privada. Curitiba: Juruá, 2001.

MANCEBO, Rafael Chagas. A função social do contrato: de acordo com o novo Código Civil. São Paulo: Quartier Latin, 2005.

MARINO, Francisco Paulo de Crescenzo. Interpretação do negócio jurídico. São Paulo: Saraiva, 2011.

MARQUES, Cláudia Lima. Contratos no Código de Defesa do Consumidor. São Paulo: Revista dos Tribunais, 2002.

Tribunais, 2003.

et al. Comentários ao Código de Defesa do Consumidor. São Paulo: Revista dos 
O "diálogo das fontes" como método da nova Teoria Geral do Direito. In:

(coord.). Diálogo das fontes. Do conflito à coordenação de normas do direito brasileiro. São Paulo: Revista dos Tribunais. 2012.

MARTINS, Fernando Rodrigues. Princípio da Justiça Contratual. São Paulo: Saraiva, 2009.

MARTÍNEZ VELENCOSO, Luz M. Riesgo negocial v. cláusula "rebus sic stantibus". Barcelona: Revista para el Análisis Del Derecho. Enero 2011. http://ssrn.com/abstract= 1762779. Acesso em 24 abr. 2012.

MARTINS-COSTA, Judith. A boa-fé no Direito Privado. São Paulo: Revista dos Tribunais, 1999.

Comentários ao novo Código Civil. São Paulo: Saraiva, 2003. vol. 5, t. 1, 2003.

MERENIUK, Ruy Orlando. Teoria da imprevisão. Curitiba: Juruá, 2009.

MIRAGEM, Bruno. Direito do Consumidor. São Paulo: Revista dos Tribunais, 2008.

Eppur si muove: diálogo das fontes como método de interpretação sistemática. In:

MARQUES, Cláudia Lima (coord.). Diálogo das fontes. Do conflito à coordenação de normas do direito brasileiro. São Paulo: Revista dos Tribunais. 2012.

MIRANDA, Custódio da Piedade Ubaldino. Teoria geral do negócio jurídico. São Paulo: Atlas, 2009.

MONTEIRO PINTO, Antônio. Erro e vinculação negocial. Coimbra: Almedina, 2002.

MONTEIRO, Osvaldo Carvalho. Cláusula rebus sic stantibus. Revista Forense, Rio de Janeiro, v. 94, p. 242-255, 1943.

MOSCO, Luigi. Principi sulla Interpretazione dei negozi giuridici. Napoli: Casa Editrice Dott. Eugenio Jovene, 1952.

MOTA PINTO, Paulo. Declaração tácita e comportamento concludente no negócio jurídico. Coimbra: Almedina, 1995.

NADER, Paulo. Curso de Direito Civil - Parte Geral. Rio de Janeiro: Forense, 2004.

NALIN, Paulo. Do contrato: Conceito pós-moderno (Em busca de sua formulação na perspectiva civil-constitucional). 2. ed. Curitiba: Juruá, 2006.

NANNI, Giovanni Ettore (Coord.). Temas relevantes do direito civil contemporâneo: estudos em homenagem ao Professor Renan Lotufo. São Paulo: Atlas, 2008.

A evolução do Direito Civil Obrigacional: a concepção do Direito Civil constitucional e a transição da autonomia da vontade para a autonomia privada. In: LOTUFO, Renan (Coord.). Cadernos de Autonomia Privada. Curitiba: Juruá, 2001.

. Relação de consumo: uma situação jurídica em interação entre o Código de Defesa do Consumidor e o Código Civil. In: LOTUFO, Renan; RODRIGUES MARTINS, Fernando. 
20 anos do Código de Defesa do Consumidor - conquistas, desafios e perspectivas. São Paulo: Saraiva, 2011.

NEGREIROS, Teresa. Teoria do contrato: novos paradigmas. Rio de Janeiro: Renovar, 2002.

NERY JÚNIOR, Nelson. Vícios do ato jurídico e reserva mental. São Paulo: Revista dos Tribunais, 1983.

Código de Defesa do Consumidor Comentado pelos autores do anteprojeto. Rio de

Janeiro: Forense Universitária, 2001.

NUNES, Rizzatto. Comentários ao Código de Defesa do Consumidor. 2. ed. São Paulo:

Saraiva, 2005.

.Curso de Direito do Consumidor. 7. ed. São Paulo: Saraiva, 2012.

OLIVEIRA, Anísio José. A cláusula 'Rebus Sic Stantibus'” através dos tempos. Belo Horizonte: [s.n], 1968.

A teoria da imprevisão nos contratos. São Paulo: Universitária de Direito, 2002.

OSTI, Giuseppe. Clausola "rebus sic stantibus”. Novissimo digesto italiano. Turim: Utet, 1959.

Scritti Giuridici. Milano: Giuffrè, 1973.

PASQUALOTTO, Adalberto. O Código de Defesa do Consumidor em face do Código Civil de 2002. São Paulo: Revista dos Tribunais, 2002.

PEIXOTO, Eduardo Collet e Silva. Lesão e revisão judicial do contrato. Dissertação (Mestrado) - Universidade de São Paulo, 2009.

PEREIRA, Caio Mário. Lesão nos contratos. 6. ed. Rio de Janeiro: Forense, 1999.

PEREIRA LIRA, José-Ricardo. A onerosidade excessiva no Código Civil e a impossibilidade de "modificação judicial dos contratos comutativos sem anuência do credor". In: TEPEDINO, Gustavo; FACHIN, Luiz Edson (Coord.). O Direito e o Tempo: Embates Jurídicos e Utopias Contemporâneas. Rio de Janeiro: Renovar, 2008.

POLINSKY, A. Mitchell. An introduction to law and economics. New York: Aspen, 2003.

POTTER, Nelly. Revisão e resolução dos contratos no Código Civil. Rio de Janeiro: Lumen Juris, 2009.

PUGLIESE, Antonio Celso Fonseca. Teoria da imprevisão e o novo Código Civil. Revista dos Tribunais, São Paulo, v. 93, n. 830, p. 12-26, dez. 2004.

REALE, Miguel. O projeto do novo Código Civil. São Paulo: Saraiva, 1999.

REVOREDO ROBOREDO, Alda Regina. Contrato: função social e cláusulas abusivas.

Curitiba: Juruá, 2007. 
REZENDE, Christiane Leles. Pacta sunt servanda? Quebra dos contratos de soja verde. Tese (Doutorado) - Universidade de São Paulo, São Paulo, 2008.

REZZÓNICO, Juan Carlos. Principios fundamentales de los contratos. Buenos Aires: Astrea, 1999.

RIPERT, Georges. A regra moral nas obrigações civis. Campinas: Bookseller, 2000.

ROCHA, Silvio Luís Ferreira da. Princípios contratuais. In: NANNI, Giovanni Ettore (Coord.). Temas relevantes do Direito Civil contemporâneo: estudos em homenagem ao Professor Renan Lotufo. São Paulo: Atlas, 2008.

ROCHA DE GOUVEIA, Alfredo José Rodrigues. Da teoria da imprevisão nos contratos Civis. Lisboa: FDUL, 1958.

RODRIGUES, Sílvio. Dos defeitos dos atos jurídicos: do erro e do dolo. São Paulo: Max Limonad, 1959.

Dos defeitos dos atos jurídicos: da coação. São Paulo: Max Limonad, 1962.

RODRIGUES JÚNIOR, Otavio Luiz. Revisão judicial dos contratos. Autonomia da vontade e teoria da imprevisão. São Paulo: Atlas, 2006.

ROPPO, Enzo. O contrato. Coimbra: Almedina, 1977.

RÖSLER, Hannes. Hardship in German Codified Private Law. Comparative Perspective to English, French and International Contract Law. In European Review of Private Law, Hamburg, v.15, n. 4, p. 484, 2007.

SACCO, Rodolfo; DE NOVA, Giorgio. II contrato. 3.ed. Torino: Torinese. Tomo Secondo, 2004.

SAMPAIO. Laerte Marrone de Castro. A boa-fé objetiva na relação contratual. Barueri: Manole, 2004.

SANTOS, Antonio Jeová. Função social: lesão e onerosidade excessiva nos contratos. São Paulo: Método, 2002.

SANTOS, Regina Beatriz Tavares da Silva Papa dos. Cláusula 'Rebus Sic Stantibus' ou teoria da imprevisão. Revisão Contratual. Belém: CEJUP, 1989.

SCHWARTZ, Andrew A. A "Standard Clause Analysis" of the Frustration Doctrine and the Material Adverse Change Clause, Los Angeles, v. 57, U.C.L.A Law Review, 2010.

SCHUNCK, Giuliana Bonanno. A onerosidade excessiva superveniente no Código Civil: críticas e questões controvertidas. São Paulo: LTR, 2010.

SCOGNAMIGLIO, Cláudio. Interpretazione del contratto e interessi dei contraenti. Padova: Casa Editrice Dott. Antonio Milani, 1992.

SERRANO NEVES, Geraldo. Teoria da imprevisão e cláusula “Rebus sic stantibus”. São Paulo: Saraiva, 1957. 
SIDOU, J. M. Othon. A cláusula "Rebus sic stantibus" no Direito Brasileiro. Rio de Janeiro: Freitas Bastos, 1962.

A revisão judicial dos contratos e outras figuras jurídicas (A Cláusula ''Rebus Sic Stantibus'. Dos Efeitos da Fiança. Empresa Individual de responsabilidade limitada). Rio de Janeiro: Forense, 1978.

SILVA, Luís Renato Ferreira da. Revisão dos contratos: do Código Civil ao Código de Defesa do Consumidor. Rio de Janeiro: Forense, 2001.

SILVA FILHO, José Carlos Moreira da. Hermenêutica Filosófica e Direito: o exemplo privilegiado da boa-fé objetiva no Direito Contratual. Rio de Janeiro: Lumen Juris, 2003.

SOMOGIE, Nathan. Failure of a "Basic Assumption". The Emergin Standard for Excuse under MAE Provisions. Disponível em: http:/ssrn.com/abstract=1448916. Acesso em: 24 abr. 2012.

TEPEDINO, Gustavo. Temas de Direito Civil. Rio de Janeiro: Renovar, 1999.

Aplicabilidade do Código Civil nas relações de consumo: diálogos entre o Código Civil e o Código de Defesa do Consumidor. In: LOTUFO, Renan; RODRIGUES MARTINS, Fernando. 20 anos do Código de Defesa do Consumidor - conquistas, desafios e perspectivas. São Paulo: Saraiva, 2011.

THEODORO JÚNIOR, Humberto. O contrato e sua função social. Rio de Janeiro: Forense, 2004.

TRABUCCHI, Alberto. Istituzioni di Diritto Civile. Milani: Casa Editrice Dott Antonio, 1999.

TUSA, Gabriele. Cláusulas gerais no Código Civil de 2002: Reflexões Acerca de sua Aplicação. Tese (Doutorado) - Universidade de São Paulo, São Paulo, 2008.

VELOSO, Zeno. Invalidade do negócio jurídico: nulidade e anulabilidade. Belo Horizonte: Del Rey, 2002.

VENOSA, Sílvio de Salvo. Direito Civil. v. II. São Paulo: Atlas, 2010.

ZENEDIN GLITZ, Frederico Eduardo. Contrato e sua conservação: lesão e cláusula de hardship. Curitiba: Juruá, 2008. 